\title{
Suplemen Materi Statistik Terapan dalam Ilmu Kesehatan
}

Disusun Oleh:

Andi Jusmiana

Herianto 


\section{PENGANTAR}

Dengan berharap ridha dan rahmat Allah SWT, Modul Suplemen Materi Statistik Terapan

dalam Ilmu Kesehatan ini dapat diselesaikan sesuai dengan rencana yang telah ditentukan. Buku ini disusun sebagai salah satu upaya penulis membantu dosen dan mahasiswa di Fakultas Kesehatan Masyarakat UPRI Makassar dalam mempelajari statistik yang bersifat terapan dalam bidang penelitian khususnya bidang kesehatan. Modul ini disusun secara ringkas dengan maksud menyajikan informasi praktis mengenai Statistik Terapan dalam Bidang Ilmu Kesehatan, diantaranya: pengenalan statistic dan data, pengumpulan data, pengolahan data, penyajian data, dan teknik analisis data.

Penulis menyampaikan penghargaan yang setinggi-tingginya atas peran serta berbagai pihak dalam penyelesaian penulisan modul ini. Khususnya kepada Pimpinan Universitas Pejuang Republik Indonesia (UPRI) Makassar, yang telah memberikan kesempatan sehingga Modul ini bisa digunakan sebagai suplemen dalam mata kuliah Biostatistik pada Fakultas Kesehatan Masyarakat UPRI Makassar.

Buku ini memerlukan masukan dari berbagai pihak terutama dosen pengampu statistik, mahasiswa, guru, dan siapa saja yang membaca buku ini, untuk penyempurnaan lebih lanjut.

Makassar, 1 Juni 2020

\section{Penyusun}




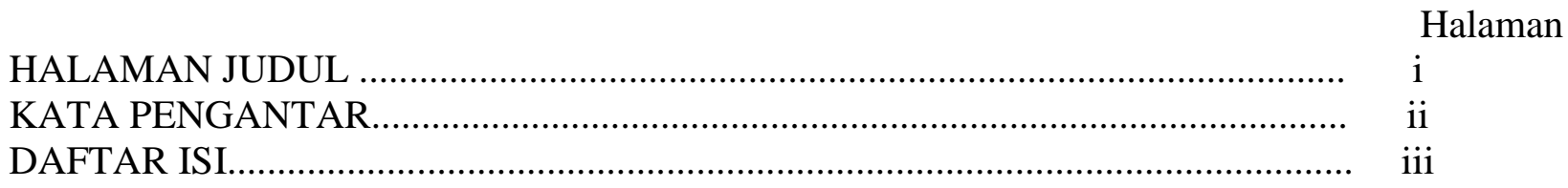

BAB I $\quad$ PENGENALAN STATISTIK DAN DATA....................................... 1
A. Statistik
B. Data

BAB II PENGUMPULAN DATA................................................................. 7
A. Populasi.....
B. Sampel.
C. Metode Pengumpulan Data............................................................. 11
D. Alat Pengumpul Data................................................................... 14
E. Syarat Alat Pengumpul Data.......................................................... 14

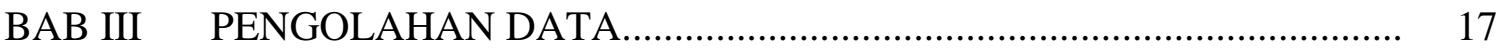

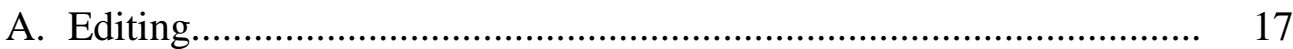

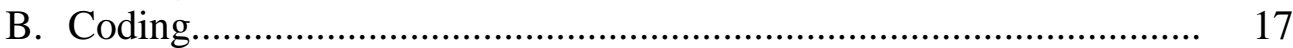
C. Klasifikasi................................................... 17

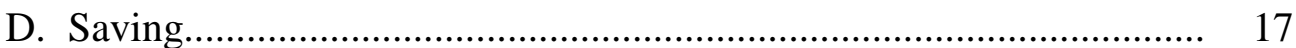
E. Tabulating ................................................. 18

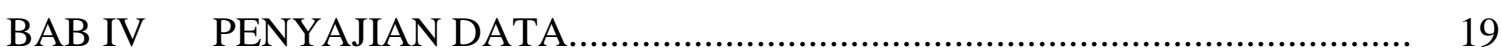

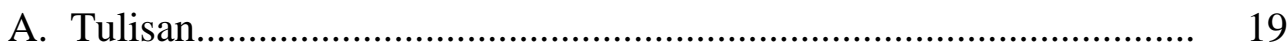

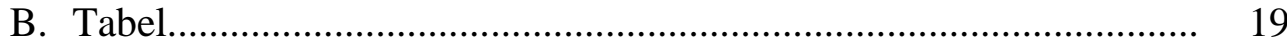
C. Grafik / Diagram / Gambar........................................................... 26

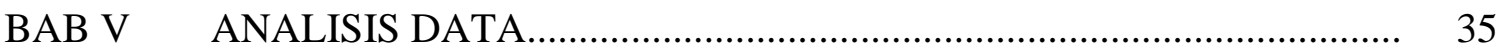
A. Proporsi
B. Ukuran Tendensi Central............................................................ 35
C. Variability...................................................................... 45

BAB VI SIMPULAN...................................................................... 51
A. Hipotesis.

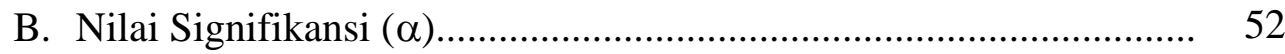
C. Rumus Statistik Penguji............................................................. 52
D. Nilai Statistik................................................................................ 53
E. Df/Db/Dk (Degree Of Freedom/Derajat Bebas/Derajat Kebebasan) 53
F. Nilai Kritis / Nilai Tabel.................................................................. 53
G. Daerah Penolakan............................................................... 54
H. Simpulan................................................................. 55

BAB VII TERAPAN RUMUS UJI STATISTIK (UJI BEDA).......................... 56
A. $\mathrm{Z}$ test untuk menguji beda mean.
B. $t$ test untuk menguji beda mean................................................... 58
C. $t$ test (pre - post) Uji beda dua mean data berpasangan................... 59 
D. $t$ test (post - post) Uji beda dua mean data tidak berpasangan......... 62

E. Uji U Mann-Whitney beda dua mean............................................ 64

F. Z test untuk menguji beda proporsi............................................ 67

G. Z test untuk menguji beda dua proporsi......................................... 69

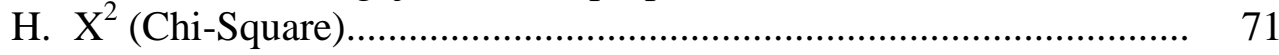

I. Analisis Varians (Anava) ............................................................ 75

J. Uji Normalitas (Uji Goodness of fit Distribusi Normal) Metode Chi Square (n besar)................................................................. 80

K. Uji Normalitas Metode Lilliefors (n kecil dan n besar).................. 82

BAB VIII TERAPAN RUMUS UJI STATISTIK (UJI HUBUNGAN)................. 85

A. Koefisien Kontingensi ( C )......................................................... 86

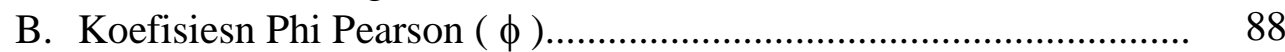

C. Koefisien Korelasi Tata Jenjang Spearman ( rho )............................. 91

D. Koefisien Korelasi Moment Product Pearson ( r )........................... 93

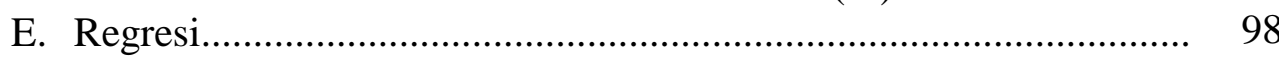

\section{DAFTAR PUSTAKA}

\section{LAMPIRAN}

1. Tabel Distribusi Normal

2. Tabel Harga Kritis t

3. Tabel Harga Kritis Koefisien Korelasi Moment Product Pearson (r)

4. Tabel Harga Kritis Koefisien Korelasi Tata Jenjang Spearman (rho)

5. Tabel Harga Quantil Statistik Lilliefors Distribusi Normal

6. Tabel Harga Kritis Chi - Square $\left(\mathrm{X}^{2}\right)$

7. Tabel Harga Kritis $F$

8. Tabel Nilai $\mathrm{q}$

9. Tabel Angka Random

10. Tabel Besar Sampel Berdasarkan Rumus

11. Tabel Angka, Akar dan Kwadrat 


\section{BAB I \\ PENGENALAN STATISTIK DAN DATA}

\section{A. Statistik}

Kata statistik berasal dari bahasa Latin "Ratio Status" yang dalam bahasa Itali ekivalen dengan kata "Region di stato". Istilah tersebut muncul pada awal abad pertengahan, biasa digunakan untuk menyatakan hal-hal yang berhubungan dengan pelajaran tentang kenegaraan. Kemudian berkembang istilah "statistia" yang berarti orang yang berkecimpung dalam urusan keadaan kenegaraan atau ahli negara. Memang pada mula perkembangannya, para ahli negara inilah yang menerapkan statistik dalam arti mengumpulkan dan menganalisis data dalam bentuk angka tentang masalah-masalah kenegaraan. Misalnya tentang kependudukan, pertanian, militer dan tenaga kerja. Selanjutnya statistik terus berkembang tidak hanya masalah kenegaraan saja, tetapi juga mencakup masalah-masalah lain sejalan mengikuti perkembangan ilmu pengetahuan.

\section{Perkembangan Statistik}

Statistik dideteksi orang mulai ada sejak Raja Ramses II sekitar tahun 1250 SM. Raja Ramses II sudah mulai melakukan pencatatan secara sederhana mengenai kelahiran dan kematian. Mulai abad pertengahan (XV) statistik mulai berkembang di dataran Eropa. Sekitar tahun 1538 pada zaman Raja Henry VIII juga telah ada catatan secara teratur tentang peristiwa kesakitan dan kematian. Sedangkan statistik vital sendiri di Inggris mulai dikembangkan sekitar tahun 1594.

Pada tahun 1603 Graunt dan Petty menerbitkan mingguan berkala mengenai kehidupan yang ditemukan dalam masyarakat, mereka melakukan analisis mengenai peristiwa prevalensi, epidemi penyakit kronis. Secara tersendiri John Graunt pada tahun 1662 menerbitkan suatu laporan "Natural and Political Observation Mentioned Following Index and Made Upon The Bill of Mortality". Sehingga John Graunt mendapat julukan bapak statistik kesehatan. Beberapa pokok kesimpulan tulisan beliau tentang perikehidupan :

a. The regurality of vital phenomena - human being are born, live and die.

b. Male births axceed female births.

c. The mortality rate in the earliest years of life is relatively high, age influences mortality.

d. Urban death rates are higher than rural death rates.

Quetelet (1796-1874) yang juga dikenal sebagai bapak statistik adalah orang yang pertama memperkenalkan bagaimana mengumpulkan informasi secara modern. Karyanya antara lain meliputi statistik terapan, pelaksanaan sensus, pengembangan keragaman pengumpulan data, studi perbanding antar bangsa. Teori probabilitas dikembangkan oleh Laplace (1749). Teori ini dikembangkan dari model permainan judi yang marak di Perancis maupun Inggris pada abad XVII. Normal Curve of Error ditemukan oleh Gauss (1777-1853), sedangkan Galton (1822-1911) menemukan dasar teori tentang korelasi dan regresi. Pearson (1857-1936) menemukan teori Chi-Square Distribution. Lebih lanjut Gosset (1876-1937) dan Fisher (1890-1962) berturt-turut menemukan Student t Distribution dan Distribusi F.

Dalam bidang statistik kesehatan William Farr (1839) di Inggris adalah orang yang pertama merintis pelaksanaan analisis data register dan sensus, sehingga diketahui penyebab kematian secara alamiah, disamping itu juga banyak mempelopori dalam bidang sanitasi serta kedokteran. Samuel Shattuck (USA) membuat analisis statistik 
terhadap masalah kesehatan masyarakat di USA, bukunya antara lain Census of The City of Boston (1845), Report of The Sanitari Commision of Massachusetts (1850). Tahun 1875 di Inggris dan Wales ditentukan kewajiban pencatatan tentang peristiwa kelahiran hidup, kematian dan perkawinan. Tahun 1893 mulai dibuat suatu klasifikasi penyebab kematian internasional (The International List of Causes of Death). Tahun 1897 di Ceylon telah dilakukan kewajiban pencatatan tentang peristiwa kelahiran hidup, kematian dan lahir mati (still birth). Tahun 1992 dilaksanakan revisi yang kesepuluh klasifikasi penyakit secara internasional (International Classification of Desease)

\section{Pengertian Statistik}

Statistik dalam arti sempit hanya didefinisikan sebagai fakta-fakta berbentuk angka yang terangkum dalam tabel-tabel atau kumpulan angka pada tabel yang menerangkan suatu fenomena.

Pengertian secara luas statistik diartikan sebagai metoda, cara atau teknik mengumpulkan data, mengolah data, menyajikan data, mengalisis data dan menarik kesimpulan berdasarkan data.

Banyak buku yang mendefiniskan statistik secara berbeda, dalam arti sempit biasanya hanya disebut statistik, sedangkan statistik dalam arti luas biasa disebut statistika.

3. Ruang Lingkup Statistik

\section{a. Statistik Deskriftip (Statistik Deduktif)}

Statistik deskriptif adalah bidang statistik yang meliputi : pengumpulan data, pengolahan data, penyajian data dan analisis data secara sederhana. Dengan tujuan untuk menggambarkan keadaan atau karakteristik populasi yang dikaji. Alat yang digunakan biasanya dalam bentuk tabel, grafik, diagram, peta, gambar, dll. Hasil perhitungan analisis yang dapat dihadirkan, yaitu, proporsi, modus, median, mean, variansi dan standar deviasi.

b. Statistik Analitik / Inferensial (Statistik Induktif)

Statistik analitik adalah bidang statistik yang mencakup semua kegiatan statistik secara utuh mulai dari kegiatan pengumpulan data, pengolahan data, penyajian data, analisis data dan penarikan simpulan berdasarkan data yang ada. Statistik analitik memiliki tujuan akhir untuk membuat inference atau menggeneralisasi hasil pengukuran sampel dari unit populasi. Alat yang digunakan pada statistik analitik adalah teori estimasi, pengujian hipotesis, dll.

4. Tujuan
a. Memahami, menganalisis record, registrasi, data, informasi
b. Menggambar keadaan objek yang dikaji
c. Menjelaskan faktor yang mendasar terhadap objek yang dikaji
d. Melihat hubungan antar variabel
e. Melihat perbedaan
f. Membantu menyusun suatu teori
g. Memprediksi keadaan
h. Mengendalikan

5. Kegunaan Statistik Dalam Bidang Kesehatan

a. Memberi keterangan tentang masalah-masalah kesehatan masyarakat yang dihadapi serta hal-hal perlu mendapat prioritas. 
b. Memberikan keterangan penyebaran penyakit berdasarkan orang yang diserang, waktu penyerangan, luasnya wilayah serang dan kecenderungannya.

c. Memperkirakan perkembangan suatu penyakit dengan berdasarkan periodisasinya / trend.

d. Memperkirakan faktor-faktor penyebab masalah, fakta yang akan dan telah terjadi.

e. Memperkirakan sumber daya dan potensi pemanfaatan serta pengembangannya dalam upaya mengantisipasi permasalahan yang terjadi.

f. Merencanakan upaya yang efektif, efisien berdasarkan kenyataan, prioritas dan sumber daya yang tersedia.

g. Memahami, menganalisis data dan informasi guna membantu mengambil keputusan.

h. Menganalisis hambatan pelaksanaan program kesehatan masyarakat serta alternatif pemecahannya.

i. Menilai hasil-hasil kegiatan yang telah dicapai.

j. Mendokumentasikan semua data kesehatan masyarakat, untuk dapat dibandingkan dengan daerah lain atau keadaan yang akan datang.

k. Dll.

B. Data

\section{Pengertian Data}

Data berasal dari kata Latin, yaitu datum, yang merupakan bentuk jamak. Data mewakili bentuk jamak dan sekaligus tunggal, jadi sangat tidak tepat menyebutkan kumpulan angka-angka dengan data-data, cukup data saja. Dalam statistik, data adalah himpunan angka-angka yang teratur menurut kaidah-kaidah tertentu dan menunjukkan nilai suatu obyek atau fakta yang dinyatakan dengan angka. Fakta sendiri memiliki pengertian suatu gejala hasil penginderaan yang dapat berupa benda, peristiwa, pengukuran, pernyataan tentang kejadian / kenyataan. Data setelah mengalami suatu proses tertentu, sehingga dapat berkomunikasi / menjelaskan dengan mudah dipahami disebut informasi.

2. Ciri-Ciri Data

Ciri-ciri suatu data untuk mudah dikenali, yang membedakan dengan pengertian lainnya, yaitu :

a. Berbentuk angka atau simbol angka, tidak berbentuk kalimat.

b. Tersusun teratur. Berurutan sesuai dengan aturan-aturan, kaidah-kaidah, hukumhukum, rumus-rumus, dalil-dalil tertentu.

c. Agregat. Seluruh kumpulan nilai-nilai pengukuran yang merupakan suatu kesatuan dan setiap nilai pengukuran hanya mempunyai arti sebagai bagian dari keseluruhan tersebut.

3. Klasifikasi Data/Data Menurut Cara Mengukur Atau Menghitung Data

a. Data Diskrit (data anumeration)

Data diskrit adalah kumpulan angka-angka absolut yang tidak memiliki desimal atau pecahan di antara dua bilangan bulatnya. Data diskrit biasanya diperoleh dari proses membilang atau menghitung (dengan jari). Tiap objek memiliki satu satuan yang utuh, yang tidak memungkinkan untuk terjadinya secara sebagian.

Misalnya : denyut nadi 92 kali, jumlah pasien 29 pasien, jumlah puskesmas 34 puskesmas, jumlah rumah sakit 56 rumah sakit, dsb. Pada keperluan perhitungan 
masih dimungkinkan penggunaan desimal, namun pada simpulan akhir harus merupakan angka tanpa desimal.

b. Data Kontinue (data measurement)

Data kontinue adalah kumpulan angka-angka yang masih dimungkinkan memiliki bilangan desimal atau pecahan di antara dua bilangan bulatnya yang banyaknya tak terhingga, biasanya didapatkan dari proses pengukuran.

Contoh : tinggi badan $175,5 \mathrm{~cm}$, berat badan $67,75 \mathrm{~kg}$, jarak $10,7 \mathrm{~km}$, kecepatan 23 $\mathrm{m} / \mathrm{dt}$, temperatur $37^{0} \mathrm{C}$, volume 35,21 , dll.

4. Data Menurut Sifatnya

a. Data Kualitatif

Data kualitatif adalah kenyataan yang menunjukkan sifat-sifat objek yang tidak memungkinkan secara langsung dapat diubah menjadi angka, sehingga menggunakan pendekatan dalam bentuk kategori.

Contoh : lukisan indah, pemandangan bagus, wajah cantik, penataan rapi, kebijaksanaan tepat, perkataannya benar, tariannya indah. Sebenarnya sudah merupakan informasi, namun karena sulit diangkakan, maka hal tersebut disebut data.

b. Data Kuantitatif

Data kuantitatif adalah data yang dinyatakan dalam bentuk angka. Misalnya : 60 rumah, 2.345 jiwa, $23 \mathrm{~km}, 19 \mathrm{gr}$.

5. Data Menurut Sumbernya

a. Data Primer

Data primer adalah data yang diperoleh secara langsung dengan melakukan sendiri pengumpulan (wawancara, angket, observasi, test) terhadap obyek. Jadi data masih merupakan data mentah yang belum mengalami proses analisis.

b. Data Sekunder

Data sekunder adalah data yang berasal dari olahan data primer. Data sekunder biasanya didapatkan dari instansi pengumpul data (misal : Biro Pusat Statistik atau instansi lain). Jadi data tersebut telah mengalami proses analisis oleh instansi yang bersangkutan sebagai orang pertama yang mengumpulkan data, biasanya berbentuk laporan, arsip, dokumen, laporan hasil penelitian.

c. Data Tersier

Data tersier adalah data yang diperoleh dari olahan data sekunder. Data tersier biasanya dapat diperoleh pada media massa.

d. Data Kuarter

Data kuarter adalah data yang diperoleh dari data tersier yang telah diolah terlebih dahulu.

6. Skala Pengukuran Data

a. Skala Nominal

Ciri utama data berskala nominal adalah data yang satuannya hanya dapat dibedakan, antara kategori yang satu dengan lainnya tidak diketahui tingkat perbedaannya. Jadi 
intinya data tersebut hanya bisa membedakan yang satu dengan lainnya. Oleh karena tidak diketahui mana yang lebih tinggi atau mana yang lebih rendah. Sehingga kita bebas mengurutkannya, tanpa ada suatu urutan yang baku. Operasional matematis yang dapat dilakukan hanya $=$ dan $\neq$ (disamakan dan dibedakan $)$.

Contoh : Data mata pencaharian, yang dibedakan menjadi satuan : guru, pedagang, karyawan, petani, ABRI, nelayan, politikus, pemulung. Data suku bangsa : Jawa, Sunda, Madura, Batak, Sasak. Data jenis penyakit : Ispa, diare, TB paru, jantung koroner, dll. Peletakan urutan masing-masing kategori diatur sesuai dengan keinginan masing-masing penyaji, karena memang tidak ada ketentuan bakunya.

b. Skala Ordinal

Ciri utama data berskala ordinal adalah data yang satuannya dapat dibedakan dan diurutkan. Jadi pada skala ordinal ini data sudah dapat diketahui mana yang lebih tinggi, mana yang rendah dan memiliki urutan baku yang tidak boleh diacak. Urutan boleh dari atas ke bawah atau sebaliknya. Operasional matematis yang dapat dilakukan, yaitu $:=, \neq,>$, dan $<$ (disamakan, dibedakan, lebih besar dan lebih kecil).

Contoh : Data tingkat pendidikan ; SD, SLTP, SLTA, PT. Data peringkat rumah ; permanen, semi permanen, tidak permanen. Data mutu ; baik sekali, baik, sedang, jelek, jelek sekali. Data tingkatan ; I, II, III, IV.

c. Skala Interval

Ciri utama data berskala interval adalah data yang satuannya dapat dibedakan, dapat diurutkan, memiliki interval yang sama tiap satuan alat ukur, besarnya interval tidak menunjukkan arti yang sebenarnya, antara satuan alat ukur yang satu dengan lainnya memiliki skala angka nol yang tidak sama. Operasional matematis yang dapat dilakukan, yaitu $:=, \neq,>,<,+$, dan - (disamakan, dibedakan, lebih besar, lebih kecil, penjumlahan dan pengurangan).

Contoh : Data temperatur : ${ }^{\circ} \mathrm{F},{ }^{\circ} \mathrm{C},{ }^{\circ} \mathrm{R},{ }^{\circ} \mathrm{K}$. Data tahun : Tahun Jawa, Tahun Cina, Tahun Masehi, Tahun Hijriah. Data skala sikap. Data konsentrasi larutan. Masingmasing satuan alat ukur memiliki angka nol sendiri-sendiri, pada saat suatu alat menunjukkan angka nol, alat ukur yang lain belum tentu menunjukkan angka nol. Fakta yang sebenarnya, diukur tidak sama oleh setiap alat ukur sesuai dengan satuannya intervalnya. Misalnya : $312^{\circ} \mathrm{F}, 100^{\circ} \mathrm{C}, 80^{\circ} \mathrm{R}$, kenyataan dan fakta sebenarnya adalah sama, namun karena alat ukur yang dipakai memiliki satuan yang berbeda, maka angka yang dihasilkan juga berbeda. Ketika suhu menyatakan $0^{\circ} \mathrm{C}$, maka tidak semua alat ukur menyatakan $0^{\circ}$.

Besarnya interval tiap alat ukur tidak menunjukkan perbedaan fakta yang sebenarnya. Misalnya : interval $10^{\circ} \mathrm{C}$ pada $90^{\circ} \mathrm{C}$ sampai dengan $100^{\circ} \mathrm{C}$, berbeda faktanya dengan interval $10^{\circ} \mathrm{C}$ pada $0^{\circ} \mathrm{C}$ sampai dengan $10^{\circ} \mathrm{C}$. Secara numerik interval tersebut sama, yaitu $10^{\circ} \mathrm{C}$, namun kenyataan fakta yang sebenarnya berbeda, interval $10^{\circ} \mathrm{C}$ pada $90^{\circ} \mathrm{C}$ sampai dengan $100^{\circ} \mathrm{C}$, kenyataannya lebih panas daripada interval $10^{\circ} \mathrm{C}$ pada $0^{\circ} \mathrm{C}$ sampai dengan $10^{\circ} \mathrm{C}$.

d. Skala Rasio

Ciri utama data berskala rasio adalah data yang satuannya dapat dibedakan, dapat diurutkan, memiliki interval yang sama tiap satuan alat ukur, lebar interval tiap satuan alat ukur menunjukkan nilai yang sebenarnya dan antara satuan alat ukur yang satu dengan lainnya memiliki skala angka nol yang absolut. Operasional matematis yang dapat dilakukan, yaitu : $=, \neq,>,<,+,-$, x, dan : (disamakan, dibedakan, lebih besar, lebih kecil, penjumlahan, pengurangan, perkalian dan pembagian). 
Contoh : data berat ; 26, $4 \mathrm{~kg}, 0,9 \mathrm{gr}, 4 \mathrm{lb}$, data jarak : $12 \mathrm{~km}, 1$ mil, 2 feet, 3 yard. Ketika suatu alat ukur menunjukkan angka nol, maka semua alat ukur yang lain juga menunjukkan angka nol. Fakta yang sebenarnya, diukur sama oleh setiap alat ukur sesuai dengan satuan intervalnya. Misalnya : ukuran jarak $1 \mathrm{~km}$, ukuran ini dalam mil $=1,9$, walaupun angkanya berbeda namun kenyataannya dan faktanya sama. Hal ini karena interval jarak satuan alat ukur masing-masing yang berbeda. Ketika jarak tersebut $0 \mathrm{~km}$, maka semua alat ukur yang lain ; yard, mil, foot juga mengatakan 0 .

Besarnya interval tiap alat ukur menunjukkan fakta yang sama. Misalnya : suatu kain panjangnya $100 \mathrm{~m}$, interval $10 \mathrm{~m}$ pada $90 \mathrm{~m}$ sampai dengan $100 \mathrm{~m}$, sama faktanya dengan interval $10 \mathrm{~m}$ pada $0 \mathrm{~m}$ sampai dengan $10 \mathrm{~m}$. Secara numerik interval tersebut sama, yaitu $10 \mathrm{~m}$, kenyataan fakta juga sama. 


\section{BAB II \\ PENGUMPULAN DATA}

A. Populasi

1. Pengertian Populasi

Populasi adalah keseluruhan kumpulan unsur-unsur objek penelitian yang sejenis, yang akan dikaji karakteristiknya. Unsur-unsur objek penelitian tersebut dapat berbentuk manusia, makhluk hidup (tumbuhan, hewan), benda mati (rumah, sumber air, udara, pasar), benda abstrak (kegiatan, waktu).

2. Populasi Terbatas / Finite

Populasi terbatas adalah populasi yang dibatasi ruang dan waktu. Misalnya : penduduk Desa Gedang tahun 1989, partikel air Sungai Serayu tahun 1999 di Desa Kemranjen, rumah di Perumahan Griya Indah tahun 2000.

3. Populasi Tak Terbatas / Infinite

Populasi tak terbatas adalah populasi yang bebas jumlahnya tidak terbatas. Misalnya : jumlah pasir, partikel udara, partikel air.

B. Sampel

1. Pengertian Sampel

Sampel adalah sebagian anggota populasi yang diambil dengan cara tertentu untuk dikenai pengukuran. Pengambilan sampel dari keseluruhan populasi biasa disebut sampling.

2. Alasan Sampel

a. Populasi terlalu besar

b. Percobaan yang merusak

c. Sumber daya yang dimiliki terbatas

3. Besar Sampel

a. Dengan Menggunakan Rumus

1). $\quad N=\frac{Z^{2} \cdot p \cdot q}{d^{2}}$ untuk populasi tak terbatas atau lebih besar dari 10.000

Keterangan :

$\mathrm{N}$ : besarnya sampel

$\mathrm{Z}$ : nilai standar normal yang berkaitan dengan nilai $\alpha$

$\mathrm{p}:$ : probabilitas terjadinya kejadian (bila tidak ada data dibuat 50\%)

q : probabilitas tidak terjadinya kejadian (bila tidak ada data dibuat 50\%)

$\mathrm{q}=1-\mathrm{p}$
$\mathrm{d} \quad$ : tingkat kecermatan yang dinginkan

2). $n_{f}=\frac{n}{1+\frac{n}{N}}$ untuk populasi kurang dari 10.000 
Keterangan :

$\mathrm{N}$ : besarnya sampel untuk populasi lebih dari 10.000

$\mathrm{n}$ : besarnya populasi

$\mathrm{n}_{\mathrm{f}} \quad$ : besarnya sampel dengan populasi kurang dari 10.000

3). $n=\frac{N \cdot Z^{2} \cdot p \cdot(1-p)}{N \cdot d^{2}+Z^{2} \cdot p \cdot(1-p)}$

Keterangan :

$\mathrm{N}$ : besarnya populasi

$\mathrm{Z}$ : nilai standar normal yang berkaitan dengan nilai $\alpha$

$\mathrm{p}$ : probabilitas terjadinya kejadian (bila tidak ada data dibuat 50\%)

d : tingkat kecermatan yang dinginkan

$\mathrm{n} \quad$ : besarnya sampel

b. Dengan pertimbangan

1). Homogenitas populasi

Homogenitas populasi sangat mempengaruhi besarnya sampel. Pada populasi yang sangat homogen, besarnya sampel cukup sebagian kecil saja dari populasi sudah dapat mewakili. Misalnya beberapa tetes darah sudah dapat mewakili keseluruhan darah, teh dalam satu ceret cukup diambil satu sendok sudah dapat mewakili kondisi dalam satu ceret.

2). Tingkat ketepatan penelitian yang diinginkan

Tingkat ketepatan penelitian biasanya erat kaitannya dengan analisis data. Semakin tinggi tingkat ketepatan yang diinginkan, semakin besar sampel yang diperlukan.

3). Kebutuhan uji statistik yang diinginkan

Beberapa uji statistik memerlukan jumlah sampel minimal untuk dapat dilakukan uji. Misalnya $X^{2}$ memerlukan data lebih dari 20, uji t test memerlukan data asumsi berdistribusi normal atau secara awam lebih dari 30 demikian juga uji korelasi $r$. Bila suatu uji akan digunakan, maka besarnya sampel dapat disesuaikan dengan keperluan rumus uji statistiknya.

4). Sumber daya yang dimiliki

Sumber daya yang terdapat pada peneliti sangat subyektif untuk diperlukan sebagai ukuran penentuan besarnya sampel. Kemampuan yang ada pada peneliti untuk merekrut besar sampel yang akan diukur hendaknya merupakan pertimbangan yang terakhir dalam menentukan besarnya sampel. Sumberdaya yang menjadi pertimbangan biasanya berupa tenaga, biaya dan waktu untuk mengukur karakteristik yang ada pada sampel.

4. Metode Sampling

a. Random

Cara random ini biasa juga disebut dengan sampel berpeluang atau diterjemahkan acak. Setiap anggota populasi memiliki peluang yang sama untuk menjadi anggota sampel. Cara random terdiri dari :

1). Simple Random Sampling

Langkah-langkah pengambilan sampel dengan cara simple random sampling adalah sebagai berikut :

a). Tentukan besarnya populasi

b). Tentukan besarnya sampel yang diinginkan

c). Buat sampling frame / kerangka sampling / list / daftar unit populasi lengkap dengan nomor urutnya. 
d). Tulis nomor pada kertas undian, kemudian dilinting atau tulis nomor pada bola atau yang lainnya.

e). Ambil / lakukan undian untuk mengambil lintingan kertas sebanyak sampel yang diinginkan dengan mata tertutup.

f). Buat daftar nomor sampel yang terpilih.

2). Sistematik Random Sampling

Langkah-langkah pengambilan sampel dengan cara sistematik random sampling adalah sebagai berikut :

a). Tentukan besarnya populasi

b). Tentukan besarnya sampel yang diinginkan

c). Buat sampling frame / kerangka sampling / list / daftar unit populasi lengkap dengan nomor urutnya.

d). Hitung nilai range. $\mathrm{R}=$ populasi dibagi jumlah sampel, bila didapat pecahan, ambil nilai bulatnya.

e). Kelompokkan populasi, tiap kelompok sebanyak $\mathrm{R}$ sesuai dengan nomor urutnya.

f). Kelompok pertama lakukan undian ambil satu, sebagai sampel nomor yang pertama

g). Sampel kedua didapatkan dengan cara menambah nomor sampel pertama dengan R.

h). Sampel ketiga didapatkan dengan cara menambah nomor sampel kedua dengan $\mathrm{R}$, demikian seterusnya sampai sejumlah sampel yang diinginkan terpenuhi.

i). Tulis nomor yang menjadi sampel.

3). Table Random Sampling

Langkah-langkah pengambilan sampel dengan cara table random sampling adalah sebagai berikut :

a). Tentukan besarnya populasi

b). Tentukan besarnya sampel yang diinginkan

c). Buat sampling frame / kerangka sampling / list / daftar unit populasi lengkap dengan nomor urutnya.

d). Ambil tabel bilangan random. Bila tabel bilangannya 5 digit sedangkan nomor sampel terbesar hanya 2 digit, maka nomor tabel bilangan random yang dipakai 2 digit nomor yang di belakang.

e). Tanpa melihat nomor pada tabel bilangan random, jatuhkan pensil atau penunjuk pada sembarang nomor pada tabel bilangan random.

f). Nomor yang tepat dengan pensil sebagai nomor sampel yang pertama.

g). Sampel kedua, ketiga, keempat dan seterusnya, didapatkan dengan menggeser pensil ke atas atau ke bawah atau ke kanan atau ke kiri. Bila sampai ujung nomor habis, pensil geser ke atas atau ke bawah, atau ke kanan atau ke kiri kemudian pensil geser lagi kebalikan semula. Yang penting ada konsistensinya dalam pergerakan pensil. Keadaan tersebut terus bergerak sampai jumlah kebutuhan sampel terpenuhi.

h). Tulis nomor yang menjadi sampel

b. Non Random

Cara non random merupakan teknik sampling atas pertimbangan-pertimbangan tertentu. Setiap anggota populasi tidak memiliki kesempatan yang sama untuk 
menjadi anggota sampel, bahkan kadang-kadang anggota populasi tidak jelas. Teknik sampling dengan cara non random adalah sebagai berikut :

1). Purposive Sampling

Purposive sampling dikenal juga dengan nama sampling berkehendak, sampling bertujuan, sampling bersyarat, sampling pilihan atau sampling selektif. Langkahlangkah purposive sampling adalah sebagai berikut :

a). Buat sampling frame / kerangka sampling / list / daftar unit populasi.

b). Tentukan persyaratan untuk menjadi sampel.

c). Lakukan pemilihan sampel dari sejumlah anggota populasi yang ada sesuai persyaratan.

d). Buat daftar anggota sampel yang dipilih.

2). Quota sampling

Quota sampling dikenal juga dengan sampling jatah. Jadi besarnya sampel ditentukan sesuai pertimbangan tertentu. Langkah-langkah quota sampling adalah sebagai berikut :

a). Tentukan jumlah sampel yang diinginkan

b). Langsung ke lapangan melakukan pengumpulan data terhadap anggota populasi.

c). Pengumpulan data dianggap selesai bila jumlah sampel yang didapat sudah sesuai dengan keinginan atau jatah yang telah ditentukan sebelumnya.

3). Accidental / Incidental Sampling

Accidental / incidental sampling biasa disebut sampel sembarangan. Peneliti langsung ke lapangan melakukan pengumpulan data terhadap sejumlah sampel yang ditemui, berapapun jumlah sampel tidak menjadi permasalahan. Prinsipnya banyaknya sudah dianggap cukup, berarti penelitian sudah dianggap selesai.

Cara pengambilan yang lain, yaitu dengan stratified, cluster, area, multistage, proporsional, tunggal, ganda, multipel, dan sekuensial. Teknik pengambilan sampling dapat dilakukan dengan cara dikombinasi dengan random, non random atau antar kombinasi. Misalnya :

a. Stratified Random Sampling

Stratified random sampling berarti anggota populasi distrata terlebih dahulu. Teknik stratanya tergantung keinginan peneliti. Strata dapat dilakukan berdasarkan tingkat pendidikan, tingkat pendapatan, jenis rumah, jenis keluarga, jenis sumber air bersih. Langkah-langkah stratified random sampling adalah sebagai berikut :

1). Tentukan strata yang menjadi dasar pengambilan sampel

2). Kelompokkan anggota populasi sesuai dengan stratanya

3). Buat sampling frame / kerangka sampling / list / daftar unit populasi lengkap dengan nomor urutnya sesuai dengan kelompok stratanya

4). Lakukan teknik sampling sesuai teknik simple random sampling untuk masingmasing strata, sehingga didapatkan anggota sampel sesuai dengan stratanya.

5). Buat daftar anggota sampel sesuai dengan kelompok stratanya.

b. Cluster Random Sampling

Cluster random sampling menggunakan pendekatan wilayah atau bagian yang secara administratip mudah untuk dilaksanakan. Langkah-langkah cluster random sampling :

1). Tentukan unit cluster yang diinginkan, misalnya : administrasi perwilayahan, wilayah administrasi tertinggi provinsi, diikuti kabupaten/kota, kecamatan, desa/kelurahan, RW, RT. 
2). Lakukan undian terhadap kabupaten/kota, misalnya satu provinsi terdapat 12 kabupaten/kota diambil tiga, tiap kabupaten/kota diambil empat kecamatan, tiap kecamatan diambil tiga desa, dan seterusnya sampai ke unit cluster terkecil misalnya RT, yang berarti seluruh masyarakat/KK dalam RT yang bersangkutan menjadi anggota sampel.

c. Area Random Sampling

Area random sampling menggunakan pendekatan wilayah. Suatu wilayah secara geografis dibagi menggunakan garis-garis vertikal dan horizontal, sehingga terbentuk kotak-kotak. Tiap kotak diberi nomor dan selanjutnya nomor tersebut diundi. Nomor yang keluar menjadi anggota sampel. Masyarakat yang berada pada kotak gambar gografis tersebut menjadi anggota sampel.

d. Multistage Random Sampling

Multistage random sampling biasa diterjemahkan dengan sampling bertingkat/bertahap. Cara pengambilan sampel dari populasi secara bertahap, misal : anggota populasinya $1000 \mathrm{KK}$ akan diambil sampel $80 \mathrm{KK}$. Langkah pertama dari $1000 \mathrm{KK}$ diambil secara random $600 \mathrm{KK}$, kemudian dari $600 \mathrm{KK}$ yang terpilih diambil secara random $400 \mathrm{KK}$, demikian selanjutnya sampai yang terakhir diambil $80 \mathrm{KK}$.

\section{e. Proporsional}

Pengambilan sampel secara proporsional berkaitan dengan besar sampel masingmasing kelompok. Proporsional biasanya dikaitkan dengan teknik strata, besar sampel tiap strata sesuai dengan besarnya proporsi strata terhadap keseluruhan populasi.

f. Tunggal

Sampling tunggal biasanya dikaitkan dengan teknik pengambilan sampel random, yang hanya dilakukan sekali saja, tanpa ada pengulangan atau pengambilan tambahan sampel lagi.

g. Ganda

Pengambilan dengan sistem ganda biasanya dilakukan apabila pengambilan dengan hanya sekali (tunggal) hasil kesimpulannya tidak mendukung keinginan peneliti atau peneliti merasa ragu-ragu dengan hasil kesimpulan penelitian. Pengambilan sampel kedua merupakan keputusan pembanding hasil pengambilan sampel pertama.

h. Sekuensial

Pengambilan sampel dengan sekuensial berkaitan dengan kebutuhan peneliti untuk mendukung pendapatnya. Misalnya peneliti berpendapat bahwa produk A sangat digemari masyarakat. Tahap pertama diambil sejumlah sampel dan dikaji, bila hasilnya menunjukkan bahwa masyarakat tidak menggemari produk A, maka diambil sampel lagi dan dikaji lagi, demikian berulang terus sampai didapatkan kesimpulan masyarakat menggemari produk A.

\section{Metode Pengumpulan Data}

1. Data Base / Arsip / Laporan

Pengumpulan data dengan data base merupakan pengumpulan data dengan cara mendapatkan dari arsip, laporan, rekaman yang pernah dikumpulkan oleh orang lain. 
Model pengumpulan data dengan data base akan menghasilkan data sekunder, tersier atau kuarter. Data yang dihasilkan agar betul-betul dapat dipercaya, maka perlu dilakukan cek terhadap penanggungjawab data.

Alat bantu yang sering dipergunakan untuk pengumpulan data base adalah arsip, laporan, medical record, daftar riwayat hidup, rekaman audio visual, rekaman dalam disket, dll. Alat bantu data base dapat dalam bentuk elektronik (rekaman disket, audio visual) atau manual (cetakan, arsip, laporan)

2. Observasi

Observasi adalah perbuatan jiwa dan indera secara aktif untuk menangkap stimulan, gejala perubahan objek yang kemudian ditransfer dalam bentuk data atau informasi. Observasi tidak hanya sekedar pengamatan, namun kerja seluruh panca indra yang meliputi pengamatan, pengbauan, perasa, peraba dan pendengaran.

Jenis observasi :

a. Observasi terlibat

Observasi terlibat adalah suatu teknik observasi, dimana observer aktif terlibat dalam aktivitas objek yang sedang diobserver. Antara observer dan objek yang diobserver bersama-sama dalam suatu aktivitas tertentu.

b. Observasi sistematik/terstruktur

Suatu model observasi yang mempunyai struktur langkah-langkah pengamatan yang jelas, materi yang diobserver mempunyai scope yang nyata, observer lebih terarah dengan tugasnya. Biasanya observer dibekali pedoman observasi.

c. Observasi eksperimental

Observasi eksperimental adalah suatu teknik observasi dengan cara memberikan stimulan atau rangsangan terhadap objek yang sedang diobserver, kemudian reaksi objek diobservasi.

Alat bantu observasi yang sering digunakan adalah chek list, anecdotal record, catatan berkala, rating scale, mechanical device, dll.

Dalam melakukan observer perlu diperhatikan subyektivitas observer, karena hal tersebut dapat menghasilkan data yang tidak obyektif. Observer perlu ditraning, sehingga materi yang diamati jelas, data yang dihasilkan sahih. Kadangkala obyek yang diamati bertingkah, untuk itu selama pengamatan obyek yang diamati tidak perlu diberitahu sebelumnya.

3. Test/Pengukuran

Pengukuran merupakan suatu teknik pengumpulan data dengan cara membandingkan karakter spesifik objek yang diteliti dengan alat ukur yang baku, sehingga diketahui kadarnya. Saran yang perlu diberikan dengan metode pengukuran ini adalah alat ukur perlu dikalibrasi terlebih dahulu, operator mampu mengoperasikan alat dengan baik.

Alat bantu alat ukur yang baku diantaranya ; termometer, meteran, timbangan, luxmeter, sound level meter, alti meter, hygro meter, dll.

4. Wawancara

Wawancara adalah suatu proses pertukaran informasi secara timbal balik antara pewawancara dengan responden.

Jenis-jenis wawancara :

a. Wawancara bebas

Wawancara bebas adalah suatu proses wawancara yang berlangsung tanpa dipandu dengan kuesioner atau pedoman wawancara. Pewawancara hanya dibekali topik yang perlu ditanyakan, sedangkan untuk memulai, memancing topik, mengakhiri 
wawancara terserah pewawancara. Biasanya wawancara bebas ini mengembang lebar, sehingga sulit mengambil inti permasalahan yang dibicarakan.

b. Wawancara terpimpin

Wawancara terpimpin adalah suatu proses wawancara yang dipandu dengan kuesioner atau pedoman wawancara. Proses wawancara berjalan sistematik, namun biasanya agak kaku, karena pembicaraan harus sesuai kontek kuesioner.

c. Wawancara semi terpimpin

Wawancara semi terpimpin merupakan kombinasi wawancara terpimpin dan bebas. Proses wawancara berjalan sistematik dan dapat bersifat luwes, karena tidak kaku terpancang pada kuesioner saja.

Alat bantu wawancara yang sering digunakan adalah kuesioner, catatan, perekam, dll. Pengumpulan data dengan wawancara perlu diperhatikan ; kuesioner telah diujicoba terlebih dahulu, pewawancara perlu ditraning dan faktor-faktor yang mempengaruhi proses wawancara perlu diperhatikan.

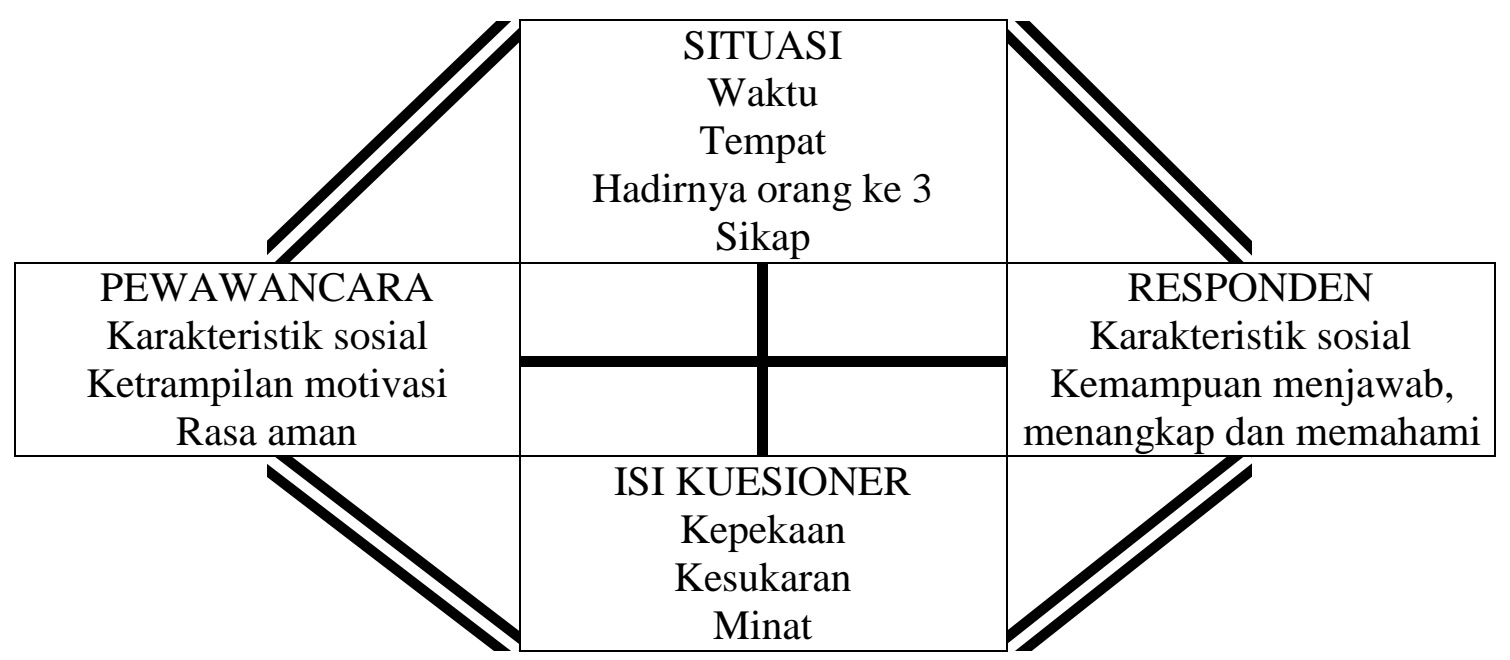

Faktor-faktor yang mempengaruhi proses komunikasi dalam wawancara

Sumber : Nasir, Moh, 1985, Metode Penelitian cetakan pertama, Jakarta : Ghalia Indonesia

5. Angket

Angket adalah daftar pertanyaan atau kuesioner yang dikirimkan kepada responden untuk diisi, kemudian dikembalikan lagi kepada pemilik kuesioner. Kelemahan yang perlu diperhatikan pada metode angket ini adalah kuesioner salah alamat, kuesioner kadang tidak dikembalikan responden, responden tidak mengerti maksud pertanyaan. Antisipasi keadaan tersebut perlu ditulis alamat yang jelas, kuesioner dilebihkan jumlahnya, perlu amplop dan perangko balasan, pertanyaan sejelas mungkin, lebih baik dalam bentuk pilihan atau isian singkat.

6. Sosiometri

Sosiometri adalah suatu teknik pengumpulan data untuk mengetahui struktur masyarakat. Struktur pokok yang dapat segera diketahui berdasarkan sosiometri adalah adanya orang yang terkenal, tokoh masyarakat dan orang yang terasing pada kelompoknya. Langkah yang perlu ditempuh metode sosiometri, yaitu tentukan masalah yang dikaji, setiap anggota kelompok diminta memilih dua orang dalam kelompok yang paling cocok dengan masalah yang dikaji, dilakukan tabulasi. Orang yang paling banyak dipilih merupakan orang terkenal dikelompoknya, sebaliknya orang yang tidak dipilih merupakan orang terasing pada kelompoknya. 
7. Diskusi kelompok

Metode diskusi kelompok tidak beda dengan diskusi biasa. Beberapa responden yang menjadi peserta diskusi dipandu peneliti membicarakan topik permasalahan yang diajukan peneliti. Pendapat para responden dicatat oleh peneliti sebagai data hasil penelitian.

\section{Alat Pengumpul Data}

1. Document / Data Base / Laporan / Arsip

Data base / laporan / arsip yang pernah dikumpulkan oleh peneliti terdahulu perlu dicek ke penanggung jawab. Document dapat berbentuk ; journal, majalah, laporan, arsip, catatan, internet, rekaman disket, dll.

2. Kuesioner

Kuesioner adalah daftar pertanyaan yang dipergunakan oleh pewawancara untuk melakukan tugas wawancara atau dikirimkan kepada responden sebagai sistem angket.

3. Chek list

Chek list adalah formulir isian atau kuesioner yang dipergunakan observer untuk melakukan tugas observasi. Pada chek list dapat berupa daftar pertanyaan tertutup atau isian singkat, sehingga observer mudah untuk mengisinya.

4. Alat Ukur Yang Baku/Standar

Alat ukur yang sesuai dengan peruntukannya dan perlu distandarisasi. Misalnya termometer untuk mengukur suhu, luxmeter untuk mengukur pencahayaan, sound level meter untuk mengukur getaran suara, hygrometer untuk mengukur kelembaban, $\mathrm{pH}$ meter untuk mengukur $\mathrm{pH}$.

5. Pemeriksaan / Analisis laboratorium

Pada kegiatan pemeriksaan ini menggunakan berbagai alat dan membutuhkan berbagai bahan untuk menguji sampel, sehingga dihasilkan suatu data. Misalnya : pemeriksaan E.Coli, BOD.

6. Panca Indra

Panca indra termasuk alat pengumpul data, baik secara langsung maupun tidak langsung. Panca indra meliputi penglihatan, pembauan, pendengaran, perasa dan peraba. Penarapan panca indra sebagai alat pengumpul data, perlu diperhatikan subyektifitas masingmasing orang, untuk itu perlu dilatih terlebih dahulu sebelum melakukan kegiatan pengumpulan data.

\section{E. Syarat Alat Pengumpul Data}

Data yang sahih merupakan data yang ingin didapatkan dari proses pengumpulan data. Data yang sahih hanya dapat diperoleh dengan menggunakan alat ukur yang memiliki validitas, memiliki reliabilitas dan petugas yang mengoperasional mampu mempergunakan alat ukur dengan baik. Jenis validitas alat ukur sebagai berikut : 


\section{Memiliki Validitas}

Pengertian validitas adalah kemampuan suatu alat ukur untuk mengukur yang seharusnya diukur atau ketepatan suatu alat ukur untuk mengukur objek yang sedang diukur. Suatu alat ukur harus memiliki validitas

a. Validitas Isi

Suatu alat ukur dikatakan memiliki validitas isi apabila di dalam alat ukur (kuesioner) sudah mengantisipasi jawaban-jawaban yang mungkin akan diungkapkan oleh responden. Ketika alat ukur dipergunakan, jawaban-jawaban responden sudah tersedia pada pilihan jawaban yang disediakan khususnya pada pertanyaan yang bersifat tertutup.

b. Validitas Konstruk

Validitas konstruk adalah suatu alat ukur yang memuat item-item pengukuran sesuai dengan kerangka konsep penelitian yang dilaksanakan. Validitas konstruk dapat dilakukan dengan mengkaji kerangka konsep dengan cara mendefinisikan secara jelas berdasarkan literatur, pendapat pakar atau mengujicoba alat ukur pada beberapa responden.

c. Validitas Budaya

Suatu alat ukur kadangkala hanya dapat dipergunakan pada kultur budaya tertentu, tidak dapat dipergunakan untuk beberapa kultur budaya yang berbeda. Suatu alat yang dapat dipergunakan untuk mengukur berbagai macam kultur budaya dikatakan alat ukur tersebut mempunyai validitas budaya.

d. Validitas internal

Validitas internal adalah saling keterkaitannya secara selaras item-item penyusunan pertanyaan pada alat ukur. Pertanyaan yang satu dengan yang lain tidak bertentangan, seharusnya saling sesuai, saling mendukung, membentuk suatu alat ukur secara keseluruhan yang memiliki missi untuk mengungkap data sesuai keinginan peneliti.

e. Validitas eksternal

Suatu alat ukur dikatakan memiliki validitas eksternal apabila hasil pengukuran yang dilakukan alat ukur tersebut dibandingkan dengan pengukuran alat ukur yang lain menghasilkan data yang sama. Alat ukur pembanding hendaknya alat yang sudah standar layak dipergunakan.

f. Validitas rupa

Validitas rupa tidak berkaitan dengan hasil data yang diukur, namun berkaitan dengan bentuk konkrit penampilan alat ukur. Validitas rupa adalah bentuk secara fisik alat ukur meyakinkan untuk dipakai sebagai alat ukur.

g. Validitas prediksi

Alat ukur yang memiliki kekampuan untuk memperkirakan yang akan terjadi pada masa mendatang pada objek disebut validitas prediksi.

2. Memiliki Reliabilitas

Reliabilitas lebih sering diartikan kestabilan suatu alat ukur untuk mengukur objek. Pengulangan pengukuran dengan alat ukur yang sama akan menghasilkan data yang sama. 
a. Reliabilitas eksternal

Reliabilitas ekternal dapat dicari dengan teknik pengulangan atau teknik bentuk paralel. Pada teknik pengulangan, kuesioner mulanya diujicobakan pada beberapa responden, kemudian selang beberapa waktu dilakukan pengukuran lagi. Hasil pengukuran pertama dikorelasikan dengan hasil pengukuran kedua. Bila korelasinya signifikan, berarti terdapat keajegan alat ukur dalam mengukur objek. Teknik bentuk paralel dengan cara alat ukur diujicobakan pada beberapa responden, kemudian responden juga diukur dengan alat ukur yang standar. Bila hasilnya kedua pengukuran sama, berarti alat ukur yang diujicobakan memiliki reliabilitas. Pembuktian sama tidaknya hasil pengukuran dapat dilakukan dengan uji beda atau uji korelasi.

b. Reliabilitas internal

Reliabilitas internal dapat dilihat dengan teknik belah dua. Kuesioner diujicobakan pada beberapa responden. Item-item pertanyaan pada kuesioner dibelah menjadi dua dengan cara secara random dikelompokkan menjadi kelompok I dan II, atau dengan cara mengumpulkan nomor yang ganjil dan genap, atau langsung secara nomor urut dibelah menjadi dua kelompok. Skor total kedua kelompok dikorelasikan dan hasil korelasi dimasukkan rumus $r_{\text {total }}=\frac{2 \cdot r_{\text {belahdua }}}{1+r_{\text {belahdua }}}$. Hasil korelasi dibandingkan dengan tabel $r$.

Keadaan validitas dan reliabilitas suatu pengukuran di lapangan kemungkinan yang terjadi dapat digambarkan sebagai berikut :

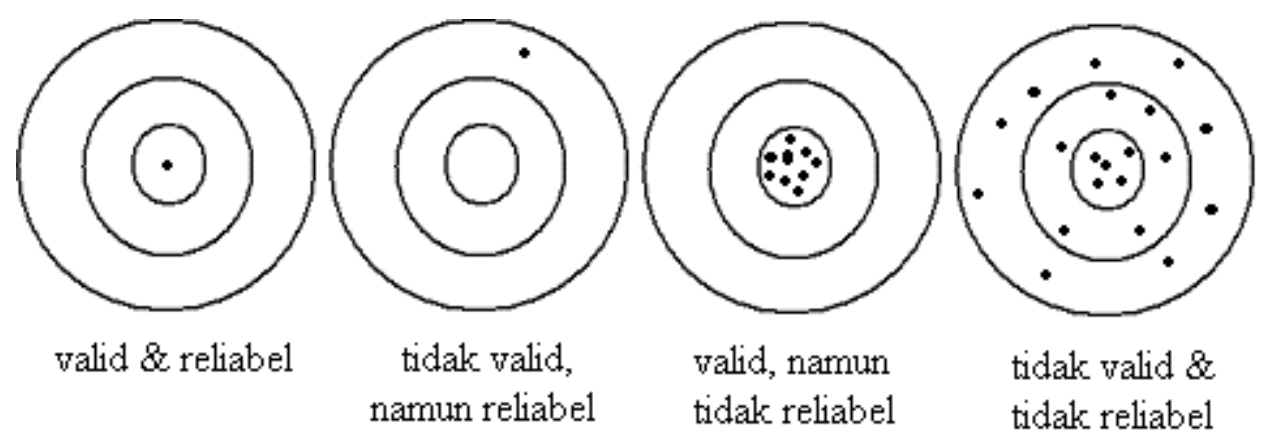

\section{Mudah Dipakai}

Alat ukur yang dipergunakan hendaknya mudah dioperasionalkan. Pemakai alat ukur atau petugas pengumpul data perlu dilatih terlebih dahulu, sehingga familiar terhadap alat ukur. 


\section{BAB III \\ PENGOLAHAN DATA}

\section{A. Editing}

Editing meliputi kegiatan koreksi dan seleksi data yang telah dikumpulkan. Data yang terkumpulkan dikoreksi satu per satu, baik data primer hasil pengukuran maupun data sekunder. Kegiatan koreksi data terkandung maksud untuk mendapat data yang benar, sehingga diharapkan nanti dalam analisis tidak terjadi kesalahan simpulan. Kegiatan seleksi data adalah memilah-milah data yang terkumpul untuk mendapatkan data yang sesuai dengan kebutuhan penelitian. Data yang tidak diperlukan disisihkan, sehingga tidak terjadi pemborosan analisis dan analisis sudah terarah sesuai dengan tujuan penelitian. Biasanya selain kegiatan koreksi dan seleksi, kegiatan editing juga dilanjutkan dengan pengelompokan data, sehingga langkah selanjutnya lebih efisien.

B. Coding

Kegiatan coding merupakan kegiatan pemberian kode pada data. Kegiatan coding bertujuan untuk meringkas data dan memudahkan dalam analisis data. Seyogyanya kode yang diberikan pada data berbentuk numerik, karena mempercepat proses analisis data pada komputer. Data yang telah berbentuk numerik tidak perlu dikode, misalnya umur, jumlah keluarga, tinggi badan, berat badan, dll. Data yang dikode umumnya data yang berskala nominal atau ordinal. Data dalam skala interval dan ratio dapats aja dilakukan pengkodean, untuk data tertentu, misalnya datanya besar. Angka kode yang telah dibuat hendaknya jangan sampai hilang, karena merupakan kunci nantinya bila data dikembalikan kepada informasi yang sebenarnya.

Contoh :

Data tingkat pendidikan meliputi : tidak tamat SD, SD, SLTP, SLTA dan PT, untuk tidak tamat SD diberi kode 1, SD dibei kode 2, SLTP diberi kode 3, SLTA diberi kode 4 dan PT diberi kode 5. Data jenis kelamin meliputi laki-laki dan wanita, laki-laki dikode 1 dan wanita dikode 2 .

C. Klasifikasi / Pengelompokan

Pada kegiatan klasifikasi, data dikelompokkan sesuai dengan kodenya, atau menurut kebutuhan analisis nantinya. Kegiatan pengelompokan dapat sekaligus dengan pengkodean, sehingga memudahkan dalam pengelompokan. Pengelompokkan dapat dilakukan secara manual atau dengan komputerisasi.

Misal : pengelompokan sosial ekonomi : yang berisi tingkat pendapatan, jenis mata pencaharian, jumlah pengeluaran. Pengelompokan sosial budaya yang meliputi data tingkat pendidikan, suku, kebiasaan, adat. Pengelompokan karakteristik responden yang meliputi umur, jenis kelamin, jumlah keluarga.

D. Saving

Kegiatan saving pada penelitian yang singkat biasanya tidak dilakukan, karena data langsung diolah dan dianalisis lebih lanjut. Pada penelitian yang memerlukan waktu yang lama seperti kohort atau longitudinal biasanya data tidak segera dianalisis, sehingga perlu dilakukan penyimpanan data. Penyimpanan data dapat dilakukan secara manual ataupun elektronik. Penyimpanan data dalam bentuk manual dapat berbentuk lembar jawaban kuesioner, kartu kode, laporan sementara. Penyimpanan dalam elekronik dapat berupa rekaman dalam disket atau hardisk komputer. 
E. Tabulating

Tabulating pada kegiatan pengolahan data merupakan kegiatan meringkas jawaban dari kuesioner menjadi satu tabel induk yang memuat semua jawaban responden. Jawaban responden dalam bentuk kode-kode yang disepakati pengolah data.

Contoh :

\begin{tabular}{|l|l|l|l|l|l|l|l|l|l|l|l|l|l|}
\hline No. & Resp & Us & Jk & Jkk & Pend & Pekj & Agm & Tran & Asr & Rsk & Inf & Skt & Hum \\
\hline 1. & Ali & 45 & 1 & 4 & 4 & 7 & 1 & 1 & 1 & 1 & 1 & 1 & 1 \\
\hline 2. & Das & 34 & 1 & 3 & 2 & 7 & 1 & 2 & 1 & 2 & 1 & 2 & 2 \\
\hline 3. & Leo & 56 & 1 & 5 & 3 & 7 & 1 & 2 & 1 & 1 & 1 & 2 & 2 \\
\hline 4. & Pit & 48 & 1 & 6 & 4 & 6 & 1 & 2 & 1 & 3 & 1 & 2 & 3 \\
\hline 5. & Puy & 50 & 2 & 5 & 3 & 5 & 2 & 2 & 1 & 3 & 1 & 2 & 1 \\
\hline 6. & Min & 46 & 2 & 5 & 3 & 2 & 1 & 2 & 1 & 4 & 3 & 2 & 2 \\
\hline 7. & Noi & 49 & 2 & 5 & 3 & 6 & 2 & 1 & 1 & 2 & 3 & 2 & 3 \\
\hline 8. & Kla & 52 & 1 & 7 & 2 & 6 & 1 & 2 & 1 & 1 & 3 & 2 & 1 \\
\hline 9. & Bas & 53 & 1 & 7 & 2 & 1 & 2 & 2 & 1 & 2 & 2 & 2 & 1 \\
\hline 10. & Asn & 60 & 2 & 7 & 2 & 1 & 3 & 2 & 1 & 2 & 2 & 1 & 3 \\
\hline dst & & & & & & & & & & & & & \\
\hline
\end{tabular}




\section{BAB IV \\ PENYAJIAN DATA}

Data yang telah dikumpulkan, baik berasal dari populasi maupun sampel tidak akan bermanfaat sebelum diolah dan disajikan. Data yang diperoleh dari pengumpulan data, baik dengan cara wawancara, pengamatan, pengukuran dan kuesioner ( data primer ) sifatnya masih kasar dan mentah. Data yang telah diolah sesuai dengan yang diinginkan, kemudian harus disajikan dalam bentuk penyajian data yang mudah dimengerti maknanya dan mudah diinterpretasikan. Penyajian data dalam bentuk apapun yang dipilih harus dapat berbicara sendiri, menjelaskan fenomena yang disajikan. Penyajian data harus mempertimbangkan kelaziman angka dan satuan ukur yang disajikan, tujuan penyajian dan konsumen yang diperkirakan memerlukan data.

Pada hakekatnya secara umum ada tiga bentuk penyajian data yang digunakan yaitu : penyajian dalam bentuk tulisan, penyajian dalam bentuk tabel dan penyajian dalam bentuk grafik / diagram / gambar.

\section{A. Tulisan}

Tujuan utama penyajian dalam bentuk tulisan adalah memberikan keterangan keseluruh prosedur, hasil dan interpretasi yang dibuat dengan menggunakan tulisan. Data disajikan dalam bentuk angka yang dirangkaikan dengan kalimat. Penyajian dalam bentuk ini merupakan penyajian data yang paling sederhana. Kemampuan untuk menerangkan data statistik sangat terbatas, dengan demikian sangat sulit memberikan gambaran yang tepat mengenai perbandingan, antar situasi dan perkembangan. Disamping itu juga kadang-kadang membingungkan, tidak efisien dan efektif.

Contoh : Luas wilayah bagian Jawa sebagai berikut :
Jakarta seluas $560 \mathrm{~km}^{2}$
Jawa Barat seluas $46.317 \mathrm{~km}^{2}$
Jawa tengah seluas $34.206 \mathrm{~km}^{2}$
DIY seluas $3.169 \mathrm{~km}^{2}$
Jawa Timur seluas $47.922 \mathrm{~km}^{2}$

B. Tabel

Tujuan penyajian bentuk tabel adalah untuk melihat perbandingan variabel-variabel, perkembangan variabel, disamping memperlihatkan suatu agregat data. Data disusun dalam bentuk baris dan kolom sedemikian rupa sehingga dapat memberikan perbandinganperbandingan yang mudah dipahami. Baris adalah deret dari kiri ke kanan, sedangkan kolom adalah deret dari atas ke bawah. Data yang disajikan dapat berbentuk angka absolut, prosentase atau keduanya.

\section{Ketentuan Penyajian Bentuk Tabel}

a. Judul tabel

Judul tabel diletakkan bagian tengah atas tabel, membentuk segitiga terbalik, simetris kanan kiri, terdiri beberapa baris (maksimal 5 baris), ditulis dengan huruf kapital. Judul tabel harus dapat menerangkan arti angka-angka yang disajikan dalam tabel, singkat jelas, lengkap dan mengenai sasaran. Persyaratan minimal judul tabel harus dapat menjawab pertanyaan apa, dimana dan kapan (what, where and when). 
Contoh :

PERKEMBANGAN KASUS MALARIA TROPICANA DI KABUPATEN SIKKA TAHUN 1990 - 1999

SARANA SANITASI DI DESA REJO TAHUN 1999

JUMLAH PENDUDUK MALUKU TAHUN 1998

KASUS KERACUNAN DIARE DI DESA WAYAN TAHUN 1999

KEGIATAN POSYANDU DI DESA MULYO TAHUN 1998

b. Stub

Stub adalah kolom yang paling kiri dari suatu tabel. Stub memberi keterangan secara rinci tentang gambaran pada setiap baris pada badan tabel, dengan kata lain stub ini adalah tempat judul baris. Kadang-kadang ada tabel yang tanpa stub, sehingga hanya berupa kolom-kolom dari atas ke bawah atau kolom untuk stub dipergunakan tempat nomor urut baris.

c. Box head

Box head terletak pada baris yang paling atas pada suatu tabel. Box head memberi keterangan secara terperinci tentang gambaran tiap kolom badan tabel, dengan kata lain box head adalah tempat judul kolom.

d. Body table / badan tabel

Body tabel terdiri atas pertemuan kolom dengan baris pada bagian tengah tabel yang hanya dipergunakan untuk meletakkan angka-angka data yang dimaksud.

e. Bagian-bagian lain tabel :

1). Nomor tabel, biasanya diletakkan pada sebelah atas judul tabel atau serangkaian dengan judul tabel.

2). Jumlah, terletak pada bagian kolom paling kanan dan atau baris paling bawah. Pertemuan jumlah kolom dan baris ini disebut grand total. Posisi ini tidak mutlak, kadang juga dapat diletakkan pada kolom setelah stub hanya untuk tujuan tertentu. Keberadaan jumlah hanya muncul ketika diperlukan. Kadangkala jumlah tidak diperlukan, karena memang data yang disajikan tidak memungkinkan untuk dilakukan penjumlahan, namun bila data memungkinkan dilakukan penjumlahan seyogya jumlah dimunculkan.

3). Catatan kaki, berfungsi untuk menjelaskan ketidaksempurnaan data pada tabel, terletak pada bawah sebelah kanan tabel. Ketidaksempurnaan data ini dapat berupa keterangan, penjelasan atau kekecualian data yang ditampilkan pada body tabel .

4). Sumber data, terletak pada sebelah bawah catatan kaki, berfungsi menjelaskan asal usul data, bila datanya merupakan data primer, maka tidak perlu sumber. Penulisan sumber data harus lengkap meliputi, asal instansi pemilik data, buku yang memuat, penanggungjawab, tanggal/bulan/tahun.

f. Ketentuan lain

Dalam tulisan ilmiah lazimnya penyajian tabel tidak boleh dipotong oleh halaman, baik secara horizontal maupun vertikal, tabel merupakan satu kesatuan utuh. Angka yang disajikan secara kolom lurus sesuai dengan satuan, puluhan, ratusannya, banyaknya angka di desimal (di belakang koma) seyogyanya seragam. Kesesuaian antara judul tabel, box head, stub dan isi tabel perlu diperhatikan. 
Secara lebih jelasnya dapat dilihat pada bagan tabel di bawah ini :

JUDUL MENJAWAB PERTANYAAN APA, DIMANA DAN KAPAN, BENTUK SEGITIGA TERBALIK, SIMETRIS, HURUF KAPITAL

\begin{tabular}{|c|l|l|l|l|l|}
\hline & & & box head & & JUMLAH \\
\hline & & & & \\
\hline stub & & & body table & & \\
\hline & & & & \\
\hline JUMLAH & & & & & GRAND TOTAL \\
\hline
\end{tabular}

Catatan kaki :

Sumber

2. Jenis - Jenis Tabel

a. Tabel induk

Tabel induk adalah tabel yang berisi berbagai macam informasi. Tujuan penyajian bentuk ini adalah untuk memberikan gambaran secara keseluruhan permasalahan yang ada dengan data yang terinci, sehingga pembaca dari berbagai latar belakang profesi pengguna dapat memperoleh setiap informasi yang diinginkan.

Contoh :

KEADAAN KESEHATAN DI INDOENSIA TAHUN 1990 S/D 1995

\begin{tabular}{|l|l|c|c|c|c|c|c|}
\hline NO & TAHUN & IR.CAMPAK & IR DBD & RSU & BOR & DPT3 & TT2 \\
\hline 1. & 1990 & 22,1 & 12,7 & 774 & 57,6 & 87 & 61 \\
\hline 2. & 1991 & 26,7 & 11,6 & 796 & 57,0 & 86 & 60 \\
\hline 3. & 1992 & 20,5 & 9,5 & 810 & 56,0 & 90 & 62 \\
\hline 4. & 1993 & 15,8 & 9,2 & 810 & 55,8 & 89 & 67 \\
\hline 5. & 1994 & 12,7 & 9,7 & 830 & 53,4 & 91 & 64 \\
\hline 6. & 1995 & 9,9 & 2,5 & 850 & 55,2 & - & - \\
\hline
\end{tabular}

Sumber : Profil Kesehatan Indonesia 1996

b. Teks tabel

Penyajian bentuk teks tabel sifatnya lebih sederhana daripada tabel induk. Bentuk teks tabel hanya spesifik menyajikan data sesuai dengan keinginan saja. Maksud penyajian bentuk ini adalah untuk menyajikan data seringkas dan seefektif mungkin sesuai dengan pokok permasalahan yang ingin dibahas. Teks tabel juga disebut tabel distribusi frekuensi.

Contoh :

ANGKA KEMATIAN BAYI (IMR) DI INDONESIA TAHUN 1971 S/D 1995

\begin{tabular}{|c|c|c|}
\hline NOMOR & TAHUN & IMR \\
\hline 1. & 1971 & 145 \\
\hline 2. & 1990 & 71 \\
\hline 3. & 1992 & 60 \\
\hline 4. & 1993 & 60 \\
\hline 5. & 1995 & 55 \\
\hline
\end{tabular}

Sumber : Profil Kesehatan Indonesia 1996 
c. Tabel distribusi frekuensi

Distribusi frekuensi adalah susunan data menurut besarnya (kuantitasnya) atau menurut kategorinya (kualitasnya). Yang pertama disebut distribusi kuantitatif dan yang kedua disebut distribusi kualitatif (kategorik). Tabel ini biasanya hanya dua kolom saja, yaitu kolom interval kelas atau variabel kategori dan jumlah atau frekuensi. Penyusunan distribusi frekuensi kualitatif atau data dalam skala nominal dan ordinal tidaklah rumit, karena kategorinya cukup jelas dan mudah dibedakan. Seandainya kategorinya banyak pun mudah diadakan penyempitan.

Misalnya : kategori sarana penyediaan air bersih terdiri ; sumur gali, sumur pompa, sumur artesis, penampungan air hujan, mata air, ledeng, sungai, telaga ; kategori nominal untuk matapencaharian terdiri ; Pegawai Negeri Sipil, TNI, Pensiunan, Karyawan, Buruh pabrik, Buruh tani, Wiraswasta, Pedagang, Petani, Nelayan, Sopir, dan masih banyak lagi yang dapat dikategorikan dll. Kategori di atas dapat dipersempit sesuai dengan kebutuhan. Mungkin dapat ditampilkan jumlah frekuensi yang besarnya saja, misalnya PNS, ABRI, Petani, Pedagang, dll. Khusus data dalam skala nominal peletakan urutan kategori sesuai keinginan penyaji. Disarankan peletakan kategori disesuai dengan urutan besarnya frekuensi. Frekuensi tertinggi diletakkan paling atas, kecuali kategori lain-lain. Data dalam skala ordinal, interval dan ratio peletakan kategori atau interval kelas urut mulai dari terbesar sampai terkecil atai sebaliknya.

Contoh :

DISTRIBUSI PENDUDUK MENURUT MATA PENCAHARIAN DI KOTIP PURWOKERTO TAHUN 1998

\begin{tabular}{|c|l|r|}
\hline NOMOR & JENIS MATAPENCAHARIAN & JUMLAH \\
\hline 1. & Pedagang & 19.542 \\
\hline 2. & PNS / ABRI & 15.029 \\
\hline 3. & Buruh bangunan & 11.794 \\
\hline 4. & Buruh industri & 11.222 \\
\hline 5. & Angkutan & 7.868 \\
\hline 6. & Pengusaha & 6.812 \\
\hline 7. & Buruh tani & 5.608 \\
\hline 8. & Pensiunan & 4.973 \\
\hline 9. & Lain-lain & 35.304 \\
\hline \multicolumn{2}{|c|}{ JUMLAH } & 118.152 \\
\hline
\end{tabular}

Sumber : BPS Kabupaten Banyumas Tahun 1999

Pada kategori skala ordinal, tidak berbeda dengan skala nominal. Pada data skala ordinal prinsipnya urutan harus diperhatikan, tidak boleh dibolak balik, harus urut menurut kelazimannya, dapat dimulai dari yang terbesar ke terkecil maupun sebaliknya.

Misal : Kualitas sajian suatu makanan dapat dikategorikan menjadi ; sangat baik sekali, sangat baik, baik, sedang, jelek, sangat jelek, sangat jelek sekali. Kategori tersebut dapat dipersempit hanya dengan tiga kategori saja, yaitu baik, sedang, jelek. Karena biasanya kategori yang ekstrim (sangat baik sekali, sangat baik, sangat jelek, sangat jelek sekali) jumlah frekuensinya kecil.

Contoh lain misalnya tingkat pendidikan yang diurut dari pendidikan tinggi sampai tidak bersekolah. Seharusnya ada kategori Pendidikan Tinggi S3, S2, S1, D III, D II, D I, SLTA, SLTP, SD, Belum tamat SD dan Tidak sekolah. Untuk lebih efisiennya dipersempit menjadi kategori : Pendidikan Tinggi, SLTA, SLTP, SD, Belum tamat SD. 
Contoh :

DISTRIBUSI PENDUDUK 10 TAHUN KEATAS MENURUT TINGKAT PENDIDIKAN DI KOTIP PURWOKERTO TAHUN 1997

\begin{tabular}{|c|l|r|}
\hline NOMOR & \multicolumn{1}{|c|}{ TINGKAT PENDIDIKAN } & JUMLAH \\
\hline 1. & Perguruan tinggi / akademi & 6.531 \\
\hline 2. & Tamat SLTA & 22.440 \\
\hline 3. & Tamat SLTP & 32.677 \\
\hline 4. & Tamat SD & 81.144 \\
\hline 5. & Belum tamat SD & 55.186 \\
\hline \multicolumn{2}{|c|}{ JUMLAH } & 197.978 \\
\hline
\end{tabular}

Sumber : Profil Kesehatan Kabupaten Banyumas Tahun 1997

Penyusunan distribusi frekuensi kuantitatif, jika rentang (beda nilai tertinggi dan terendah) datanya kecil, tidaklah sulit, tetapi jika rentang datanya besar, maka agak menyulitkan. Penyajian tabelnya akan memanjang ke bawah, sehingga tidak efektif. Keadaan tersebut dapat diatasi dengan cara data dapat dikelompokkan dalam beberapa kelas, yang dinamakan interval kelas. Banyaknya dan lebarnya interval kelas tergantung pada banyak dan besarnya data yang akan disusun.

Langkah-langkah menyusun data kuantitatif yang belum dikelompokkan menjadi data yang berkelompok :

1). Tentukan jumlah interval kelas ( $\mathrm{K}$ )

Menentukan jumlah interval kelas ini dapat dtempuh dengan dua cara, yaitu : langsung ditentukan antara $5 \mathrm{~s} / \mathrm{d} 15$ atau mempergunakan rumus Sturgess

$$
\begin{aligned}
& \mathrm{K}=1+3,3 \log \mathrm{N} \\
& \mathrm{K}=\text { banyaknya kelas } \\
& \mathrm{N}=\text { banyaknya angka pada data }
\end{aligned}
$$

2). Tentukan rentang / range ( $\mathrm{R}$ ), yaitu beda nilai data tertinggi dengan terendah.

3). Tentukan lebar interval ( I ) . $I=\frac{R}{K}$

4). Susun interval kelas pada tabel distribusi frekuensi. Untuk kelas pertama, batas bawah interval kelas lebih mudahnya sama dengan angka data terendah atau data tertinggi. Interval kelas berikutnya hanya menambah atau mengurangi dengan lebar interval kelas.

Contoh :

Berat badan responden penelitian di Desa Salak tahun 1997

$45,56,32,78,59,69,70,80,86,45,68,56,92,88,74,77,80,83,38,36,46,72,64$,

$71,40,46,38,58,50,52,38,48,57,69,64,43,56,44,59,63,62,70,54,75$,

1). Jumlah kelas berdasarkan rumus Sturgess $K=1+3,3 \log N=1+3,3 \cdot \log 44=$ 6,42 , di bulat menjadi 7 kelas karena termasuk data diskrit, namun dalam perhitungan tetap menggunakan 6,42

2). Rentang $=92-32=60$

3). $I=\frac{R}{K}=\frac{60}{6,42}=9,35$ dibulatkan menjadi 9, karena termasuk data kontinue.

4). Pada interval kelas 1 dimulai 32 sampai kurang dari 41, angka 41 ikut kelas 2. Pada interval kelas 2 dimulai 41 sampai kurang dari 50, angka 50 ikut kelas 3. Pada kelas 3 dimulai 50 sampai kurang dari 59, angka 59 ikut kelas 4, dst. Model lain pada interval kelas 1 dimulai angka 32 sampai dengan 40. kelas 2 mulai 41 sampai dengan 49, kelas 3 mulai 50 sampai dengan 58, dst. Penyajian tabel distribusi frekuensi dengan menggunakan tally / melidi. 
BERAT BADAN RESPONDEN PENELITIAN

DI DESA SALAK TAHUN 1997

\begin{tabular}{|c|c|l|c|}
\hline NOMOR & INTERVAL BERAT BADAN & \multicolumn{1}{|c|}{ TALLY } & JUMLAH \\
\hline 1. & $32-41$ & 41141 & 6 \\
\hline 2. & $41-50$ & 111411 & 7 \\
\hline 3. & $50-59$ & 11141111 & 9 \\
\hline 4. & $59-68$ & 1114 & 5 \\
\hline 5. & $68-77$ & 11141111 & 9 \\
\hline 6. & $77-86$ & 1114 & 5 \\
\hline 7. & $86-95$ & 111 & 3 \\
\hline \multicolumn{2}{|c|}{ JUMLAH } & & 44 \\
\hline
\end{tabular}

Pada tabel di atas, sajian interval kelas tanpa ada selah angka antara batas atas kelas dengan batas bawah kelas di bawahnya. Bila ada data yang berada pada batas atas kelas, maka data tersebut ikut kelas yang di bawahnya. Secara tidak nyata kelas 1 intervalnya mulai 32 sampai dengan 40,999...(kurang dari 41), 41 ikut kelas 2, kelas 2 intervalnya mulai 41 sampai dengan 49,999...(kurang dari 50), 50 ikut kelas 3, kelas 3 intervalnya mulai 50 sampai dengan 58,999...(kurang dari 59), 59 ikut kelas 4, kelas 4 intervalnya mulai 59 sampai dengan 67,999...(kurang dari 68), 68 ikut kelas 5, kelas 5 intervalnya mulai 68 sampai dengan 76,999...(kurang dari 77), 77 ikut kelas 6, kelas 6 intervalnya mulai 77 sampai dengan 85,999...(kurang dari 86), 86 ikut kelas 7, kelas 7 intervalnya mulai 86 sampai dengan 94,999...(kurang dari 95). Angka-angka tersebut merupakan batas-batas interval kelas nyata maupun tidak nyata, angka tersebut dipergunakan pada setiap perhitungan sebagai batas kelas.

Sajian bentuk lainnya sebagai berikut :

BERAT BADAN RESPONDEN PENELITIAN

DI DESA SALAK TAHUN 1997

\begin{tabular}{|c|c|l|c|}
\hline NOMOR & INTERVAL BERAT BADAN & \multicolumn{1}{|c|}{ TALLY } & JUMLAH \\
\hline 1. & $32-40$ & 11141 & 6 \\
\hline 2. & $41-49$ & 111411 & 7 \\
\hline 3. & $50-58$ & 11141111 & 9 \\
\hline 4. & $59-67$ & 1114 & 5 \\
\hline 5. & $68-76$ & 11141111 & 9 \\
\hline 6. & $77-85$ & 1114 & 5 \\
\hline 7. & $86-94$ & 111 & 3 \\
\hline & JUMLAH & & 44 \\
\hline
\end{tabular}

Pada tabel di atas, sajian interval kelas terdapat kesan ada selah antara batas atas kelas dengan batas bawah kelas berikutnya ; 40 dengan 41, 49 dengan 50, 58 dengan 59, 67 dengan 68, 76 dengan 77, 85 dengan 86. Secara tidak nyata interval kelas model di atas memiliki batas tidak nyata, yaitu 31,5 - 40,5, 40,5 - 49,5, 49,5 - 58,5, 58,5 - 67,5, 67,5 - 76,5, 76,5 - 85,5, 85,5 - 94,5. Dalam setiap perhitungan, batas-batas tidak nyata tersebut sebagai angka batas kelas, baik batas kelas atas maupun batas kelas bawah, jadi bukan yang tertulis pada tabel.

d. Tabel distribusi frekuensi relatif

Tabel distribusi frekuensi relatif tidak beda dengan tabel distribusi frekuensi biasa, hanya frekuensinya dalam bentuk prosentase ( \% ). Jumlah prosentase lazimnya menurut kolom, dapat juga menurut baris jika diperlukan. Jumlah prosentase harus menunjukkan angka $100 \%$, bila kurang seharusnya diupayakan dengan pembulatan, sehingga jumlahnya memenuhi $100 \%$. 
Contoh :

PROSENTASE PENDUDUK MENURUT SUMBER AIR BERSIH DI KABUPATEN BANYUMAS TAHUN 1995

\begin{tabular}{|l|l|r|r|}
\hline NOMOR & JENIS SARANA AIR BERSIH & JUMLAH & PROSENTASE \\
\hline 1. & Sumur gali & 497.597 & 71,08 \\
\hline 2. & Ledeng & 75.923 & 10,84 \\
\hline 3. & Penampungan mata air & 75.687 & 10,81 \\
\hline 4. & Sumur pompa tangan & 39.348 & 5,62 \\
\hline 5. & Penampungan air hujan & 1.158 & 0,17 \\
\hline 6. & Lain-lain & 10.380 & 1,48 \\
\hline JUMLAH & 700.093 & 100,00 \\
\hline
\end{tabular}

Sumber : Profil Kesehatan Kabupaten Banyumas Tahun 1996

e. Tabel distribusi frekuensi komulatif

Bentuk penyajian tabel distribusi frekuensi komulatif ada dua bentuk, yaitu : tabel distribusi komulatif kurang dari dan tabel distribusi komulatif lebih dari sama dengan. Skala data yang dapat disusun menjadi distribusi frekuensi komulatif adalah ordinal, interval dan ratio. Skala nominal tidak dapat disajikan dalam bentuk tabel distribusi komulatif, karena skala nominal tidak mengenal urutan kategorinya, hanya dapat dibedakan.

Contoh :

TABEL DISTRIBUSI FREKUENSI TINGGI BADAN MASYARAKAT KALIMAS TAHUN 1990

\begin{tabular}{|c|c|c|}
\hline NO. & TINGGI BADAN & JUMLAH \\
\hline 1. & $140-149$ & 22 \\
\hline 2. & $150-159$ & 39 \\
\hline 3. & $160-169$ & 25 \\
\hline 4. & $170-179$ & 7 \\
\hline 5. & $180-189$ & 1 \\
\hline 6. & $190-199$ & 100 \\
\hline
\end{tabular}

TABEL DISTRIBUSI FREKUENSI KOMULATIF KURANG DARI (<) TINGGI BADAN MASYARAKAT KALIMAS TAHUN 1990

\begin{tabular}{|c|c|c|c|}
\hline NO. & TINGGI BADAN & JUMLAH & KURANG $(<)$ \\
\hline 1. & $<140$ & 6 & 0 \\
\hline 2. & $<150$ & 22 & 6 \\
\hline 3. & $<160$ & 39 & 28 \\
\hline 4. & $<170$ & 25 & 67 \\
\hline 5. & $<180$ & 7 & 92 \\
\hline 6. & $<190$ & 1 & 99 \\
\hline 7. & $<200$ & & 100 \\
\hline \multicolumn{2}{|c|}{} \\
\hline
\end{tabular}


TABEL DISTRIBUSI FREKUENSI KOMULATIF LEBIH DARI SAMA

DENGAN $(\geq)$ TINGGI BADAN MASYARAKAT KALIMAS TH 1990

\begin{tabular}{|c|c|c|c|}
\hline NO. & TINGGI BADAN & JUMLAH & LEBIH DARI SAMA DENGAN $(\geq)$ \\
\hline 1. & $\geq 140$ & 6 & 100 \\
\hline 2. & $\geq 150$ & 22 & 94 \\
\hline 3. & $\geq 160$ & 39 & 72 \\
\hline 4. & $\geq 170$ & 25 & 33 \\
\hline 5. & $\geq 180$ & 7 & 8 \\
\hline 6. & $\geq 190$ & 1 & 1 \\
\hline 7. & $\geq 200$ & & 0 \\
\hline \multicolumn{2}{|c|}{ JUMLAH } & 100 & \\
\hline
\end{tabular}

f. Tabel distribusi relatif komulatif

Penyajian bentuk tabel distribusi relatif komulatif ini berdasarkan distribusi frekuensi relatif yang dibentuk menjadi komulatif kurang dari atau lebih dari sama dengan. Penekanan penyajian data bukan pada angka absolutnya, namun prosentase dari frekuensi, bahkan kadang-kadang angka absolutnya tidak disajikan.

g. Tabel silang

Tabel silang biasanya digunakan untuk menganalisis hubungan dua variabel atau lebih dalam data kategorik skala nominal, dapat juga untuk menganalisis perbedaan antar kelompok sampel dengan variabel pembeda dalam data nominal. Pada penggunaan analisis hubungan, maka variabel yang mempengaruhi diletakkan di box head dan variabel yang dipengaruhi diletakkan di stub. Pada analisis uji beda, variabel kategorinya diletakkan di stub dan kelompok yang diuji perbedaannya diletakkan di stub. Bila penyajian disertai dengan prosentase, maka penjumlahan $100 \%$ nya secara perkolom, dari atas ke bawah dijumlahkan $100 \%$, sebagai pembagi adalah jumlah kolom.

Contoh :

HUBUNGAN LUAS LUBANG VENTILASI RUMAH DENGAN ADANYA KASUS ISPA DI DESA REJO TH 1987

\begin{tabular}{|c|c|c|c|c|}
\hline ADANYA KASUS & \multicolumn{2}{|c|}{ LUBANG VENTILASI / (luas lantai) } & \multirow{2}{*}{ JUMLAH } \\
\cline { 2 - 4 } ISPA & $<10 \%$ & $10 \%-20 \%$ & $>20 \%$ & \\
\hline ADA KASUS & 16 & 24 & 20 & 60 \\
& $(57,14 \%)$ & $(54,44 \%)$ & $(47,62 \%)$ & $(48,39 \%)$ \\
\hline TIDAK ADA KASUS & 12 & 30 & 22 & 64 \\
& $(42,86 \%)$ & $(55,56 \%)$ & $(52,38 \%)$ & $(51,61 \%)$ \\
\hline JUMLAH & 28 & 54 & 42 & 124 \\
& $(100,00 \%)$ & $(100,00 \%)$ & $(100,00 \%)$ & $(100,00 \%)$ \\
\hline
\end{tabular}

C. Grafik / Diagram / Gambar

Penyajian bentuk grafik dimaksudkan untuk memberikan suatu kesan penglihatan dan situasi umum mengenai bahan yang disajikan tanpa harus mempelajari secara terperinci data yang ada. Pada grafik dapat juga dilihat penyebaran dan kecenderungan data. Secara umum penyajian dalam bentuk grafik memiliki alternatif fungsi dan tujuan untuk meramalkan sifatsifat dari agregat data atau tujuan untuk membandingkan sifat-sifat yang ada. 


\section{Grafik}

a. Ketentuan umum penyajian bentuk grafik

Penyajian grafik untuk tujuan meramalkan atau melihat kecenderungan. Prinsipprinsip pembuatan grafik :

1). Harus dapat menerangkan sendiri

2). Garis grafik yang disajikan harus lebih tebal dari pada garis koordinasinya (sumbu Y dan X).

3). Judul harus dapat menjawab pertanyaan apa, dimana dan kapan, diletakkan di bawah grafik, simetris, segitiga sama kaki terbalik.

4). Keterangan grafik dapat diletakkan di antara grafik dan judul.

5). Frekuensi digambarkan pada sumbu vertikal (Y) dan klasifikasi pada sumbu horinsontal (X)

6). Skala frekuensi harus mulai dari angka nol, sedangkan klasifikasi dapat dimulai dari tidak nol, pemberian tanda mulai dari kiri ke kanan dan dari bawah ke atas untuk nilai positif serta sebaliknya untuk nilai negatif.

7). Pembagian skala dan besarnya harus jelas, nilai intervalnya harus sama. Sumbu X dan Y dapat menggunakan skala yang berbeda.

8). Dapat menggunakan skala break (w) yang menunjukkan bahwa skala itu terpotong, biasanya pada sumbu Y

9). Perbandingan panjang sumbu $X$ dan sumbu $Y$ umumnya $3: 2$ atau $10: 8$

10).Fenomena yang disajikan dapat lebih dari satu

11).Lebih baik garfik diberi bingkai, sehingga satu kesatuan utuh grafik jelas batasnya

b. Jenis-jenis grafik

Jenis-jenis penyajian dalam bentuk grafik :

1). Grafik Garis

Grafik garis biasanya digunakan untuk menggambarkan perubahan nilai dalam satuan waktu. Grafik ini sangat cocok untuk data kuantitatif. Angka absis dapat dimulai dari nol atau tidak.

Pengembangan bentuk grafik garis ini bermacam-macam bentuk. Dalam bentuk dua atau tiga dimensi dapat dibuat pita, area ataupun dibuat secara bertumpuk.

Contoh :

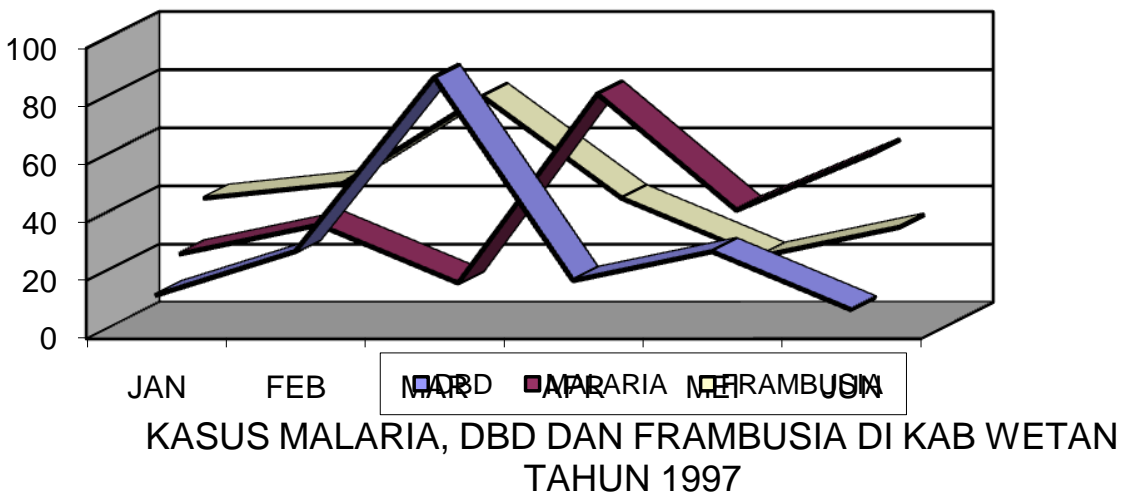




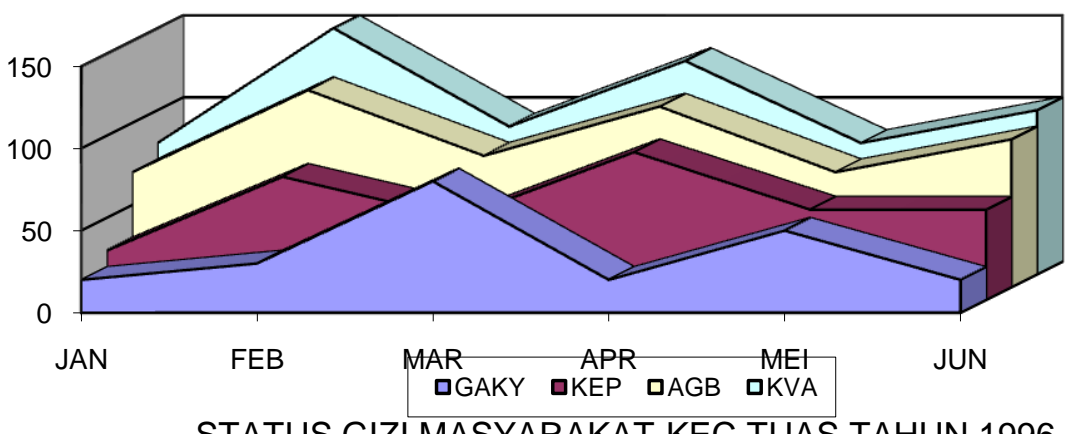

2). Histogram / Grafik Batang

Prinsip pembuatan histogram tidak beda dengan pembuatan grafik garis, hanya penyajiannya digambarkan dengan sel-sel yang mempunyai luas area yang sama frekuensi datanya. Antara sel yang satu dengan lainnya tidak ada jarak, karena datanya termasuk data kontinue, yang terus berkelanjutan, sehingga batang yang satu dengan berikutnya harus berhimpitan.

Penyajian histogram dari data yang berkelompok tidaklah sulit, karena ada interval kelas yang memiliki batas atas dan batas bawah masing-masing interval kelas, sehingga untuk menggambarkannya telah jelas batas-batas tersebut. Sedangkan untuk data yang tidak berkelompok, maka perlu dilakukan pengelompokan terlebih dahulu sesuai dengan ketentuan membuat data berkelompok pada tabel distribusi frekuensi. Selanjutnya berdasarkan tabel distribusi frekuensi tersebut diubah dalam bentuk penyajian histogram. Pada data yang berkelompok yang batas atas dan batas bawah interval kelasnya tidak bersinggungan langsung, maka antara batas data yang satu dengan yang berikutnya terbagi dua seakan-akan merupakan batas bawah dan batas atas suatu interval kelas. Jadi prinsipnya batang yang satu dengan berikutnya tidak ada selah.

Contoh :

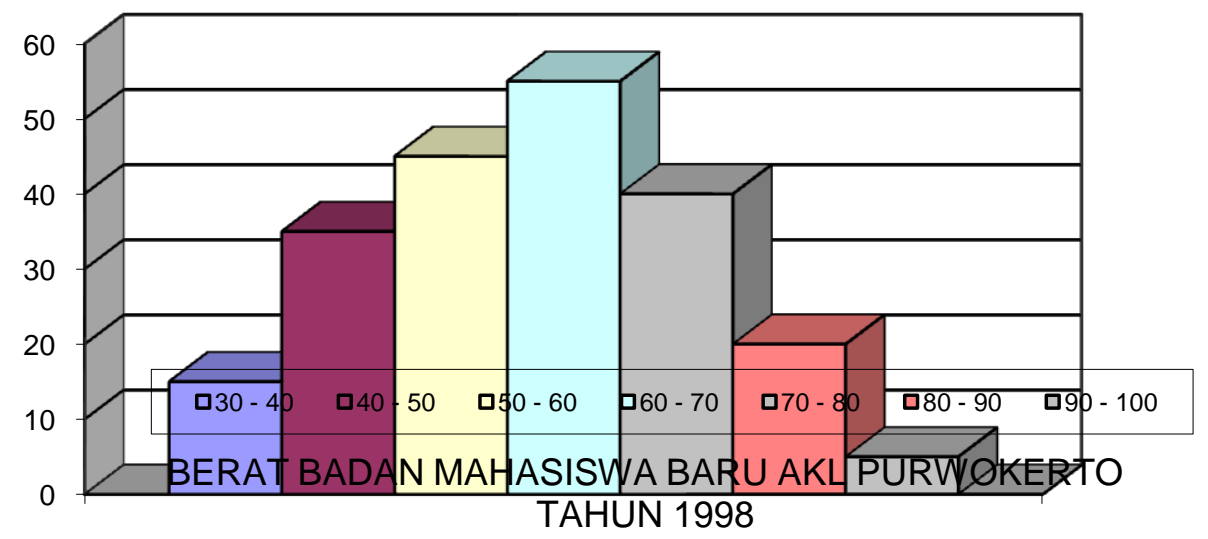


3). Poligon

Poligon adalah area yang semata-mata untuk menyajikan suatu distribusi frekuensi data kontinue. Permukaan area frekuensi poligon sama luasnya dengan permukaan area histogram yang menjadi dasarnya. Untuk menggambarkan poligon digunakan titik-titik tengah interval kelas dan titik tengah tersebut yang berada pada bagian atas batang histogram, kemudian dihubungkan dengan menggunakan garis, maka terbentuklah garis yang disebut poligon. Garis poligon harus dimulai dari sumbu $\mathrm{X}$ dan diakhiri pada sumbu $\mathrm{X}$ juga. Jadi poligon merupakan suatau area kurva yang tertutup garis dan sumbu $\mathrm{X}$.

Contoh :

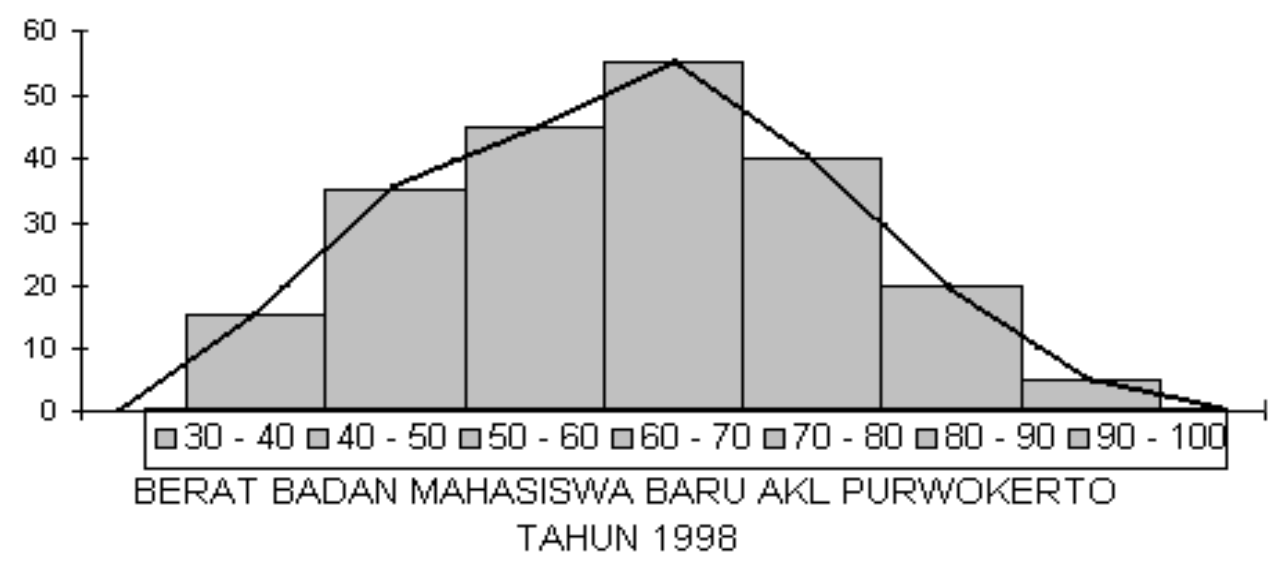

4). Ogive

Ogive adalah termasuk grafik garis yang menggunakan data dasar tabel distribusi frekuensi komulatif kurang dari atau lebih dari sama dengan.

Contoh :

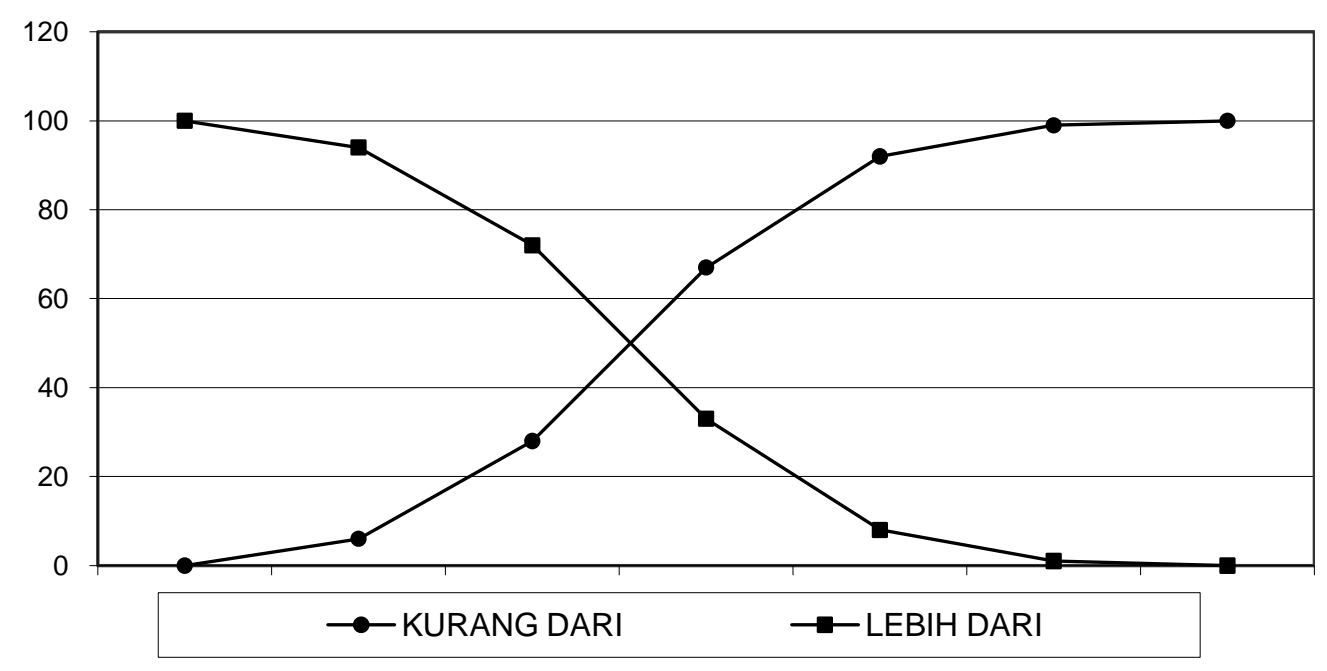

TINGGI BADAN MASYARAKAT KALIMAS TAHUN 1990

5). Scatter

Scatter dipergunakan untuk menyajikan sepasang pengamatan dari dua variabel untuk memperlihatkan ada tidaknya saling berhubungan dua variabel tersebut. Berdasarkan kondisi titik yang terjadi dapat dilihat kecenderungan pasangan data tersebut. Tiap pasang pengamatan pada satu individu atau objek disajikan sebagai sebuah titik. Sumbu X maupun sumbu Y dapat dimulai dengan angka tidak nol. 


\section{Contoh :}

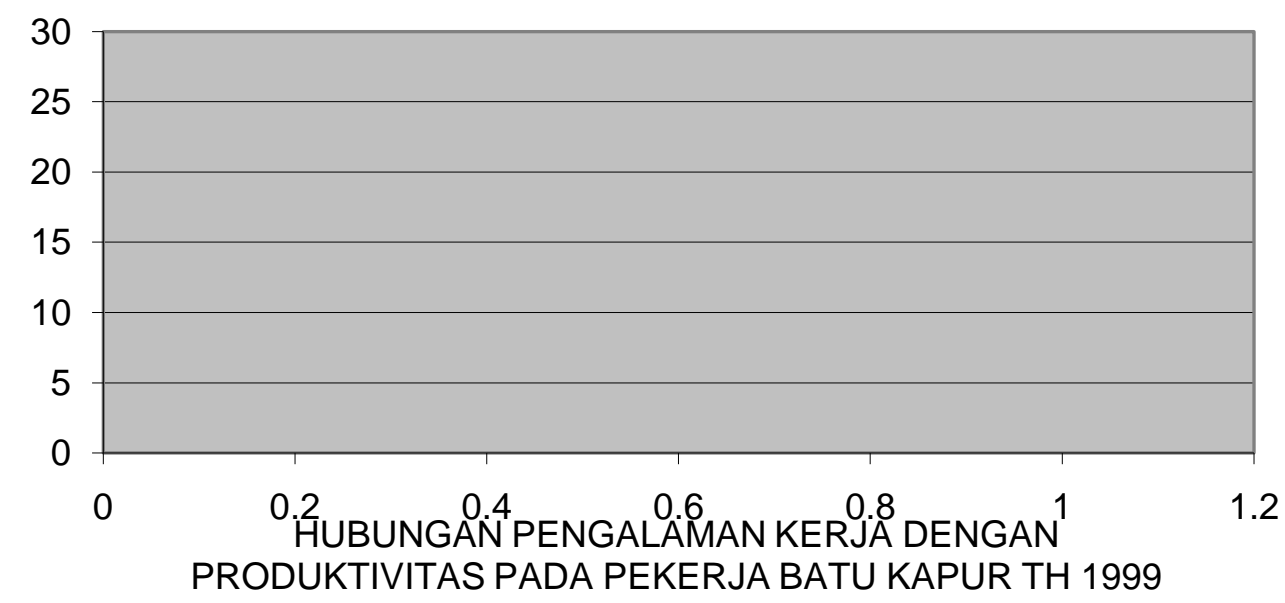

6). Radar

Penyajian bentuk radar mirip dengan cara pembuatan sarang laba-laba. Lingkaran dibagi menjadi beberapa jari-jari sesuai banyaknya klasifikasi. Besarnya sudut antar klasifikasi adalah sebesar $360^{\circ}$ dibagi banyaknya klasifikasi. Kemudian garis jari-jari sebagai skala frekuensi. Titik-titik frekuensi yang terbentuk dari fenomena data dihubungkan dengan garis grafik dan berarkhir pada frekuensi semula, sehingga terbentuk suatu area. Luasan area dapat dipergunakan sebagai analisis perbandingan.

Contoh :

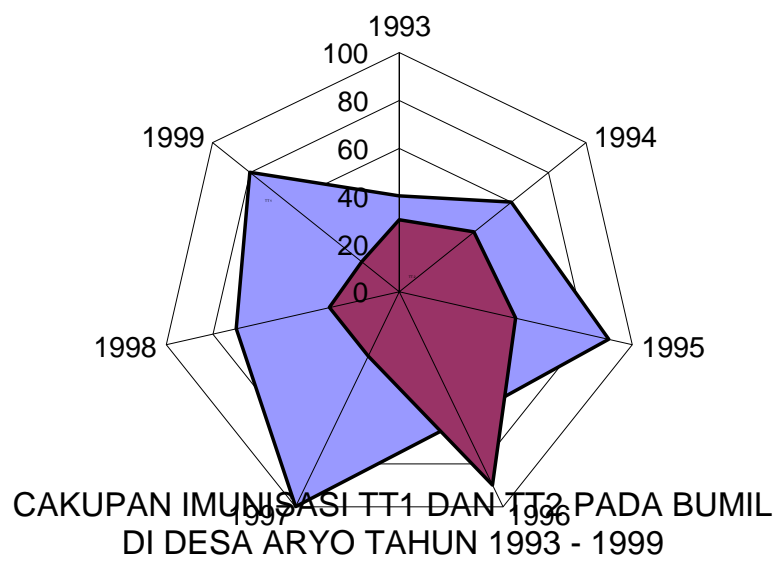

2. Diagram

Penyajian bentuk grafik dan bentuk diagram tidak berbeda. Ketentuan umum penyajian bentuk grafik juga berlaku untuk penyajian bentuk diagram. Penyajian bentuk diagram berfungsi memperlihatkan perbandingan atau proporsi secara menyeluruh. Jadi analisis data yang disajikan untuk membandingkan antar kelompok / variabel berdasarkan prosentase keseluruhan, sebagai dasar penyajian adalah tabel distribusi frekuensi relatif. Diagram kurang mementingkan angka absolutnya, namun prosentase.

Jenis-jenis diagram :

a. Diagram batang / Bar Diagram

Diagram batang kadangkala disamakan dengan histogram. Perbedaan diagram batang dengan histogram disamping data yang disajikan berbentuk proporsi, juga antar batang diagram terdapat selah, walaupun dapat juga disajikan secara berhimpitan. Jenis-jenis bar diagram ada tiga jenis, yaitu single bar, subdivided bar dan multipel bar. 
1). Single bar

Single bar merupakan sajian batang tunggal, yang membandingkan dengan bar yang lain.

Contoh :

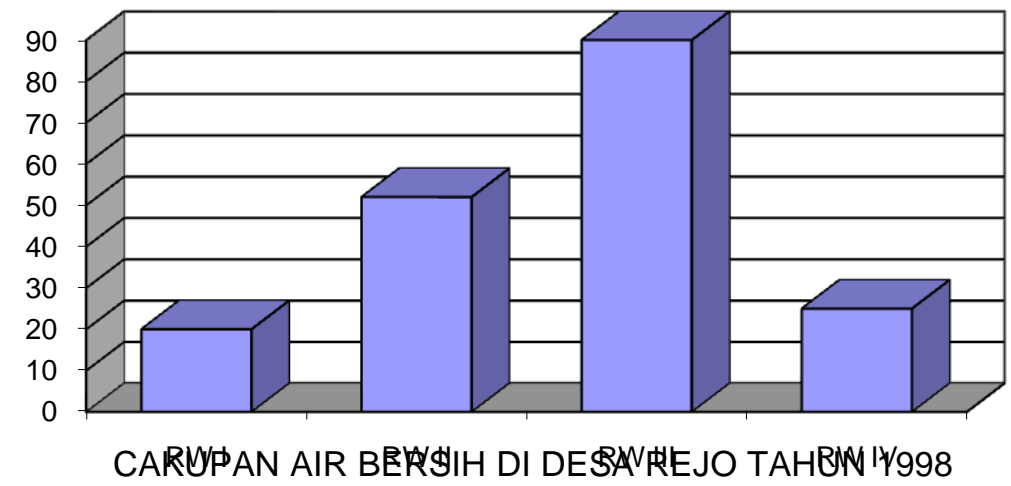

Modifikasi penyajian dapat berbentuk melintang sebagai berikut :

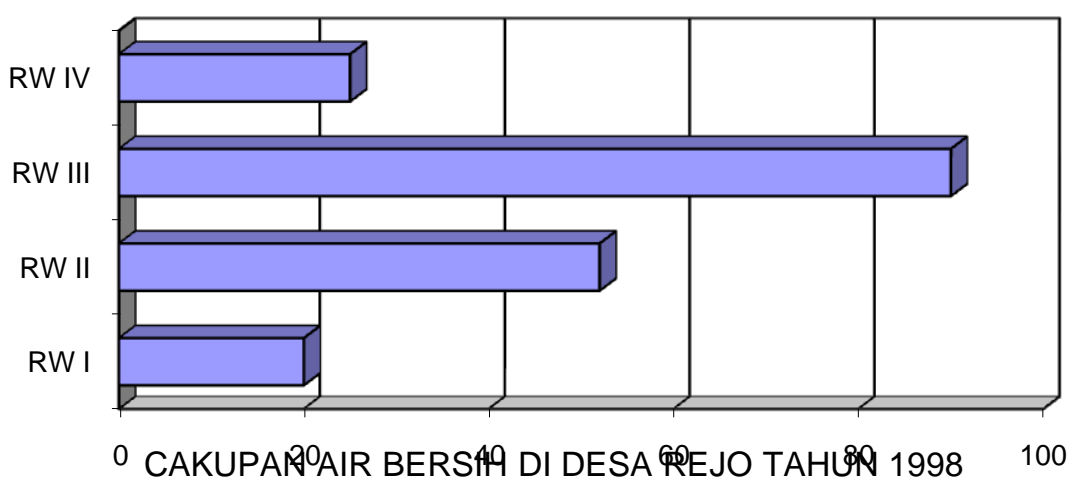

2). Subdivided bar

Subdivided bar merupakan penyajian bentuk diagram batang yang penyajian barnya secara bertumpuk. Satu tumpukan batang merupakan satu kesatuan tempat, atau waktu, yang terdiri beberapa objek.

Contoh :

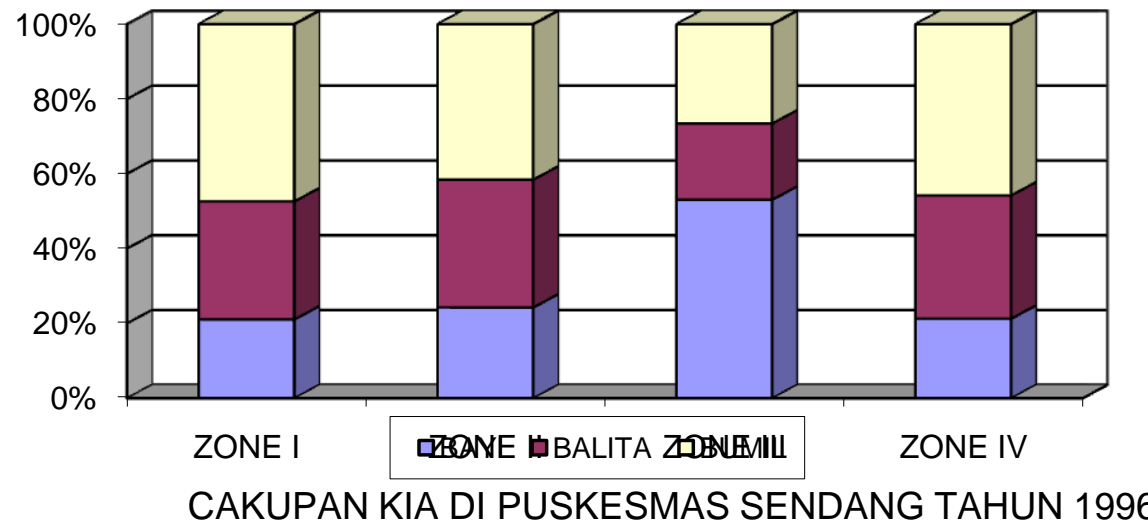


3). Multipel bar

Mulitpel bar merupakan sajian bar yang secara berdampingan.

Contoh :

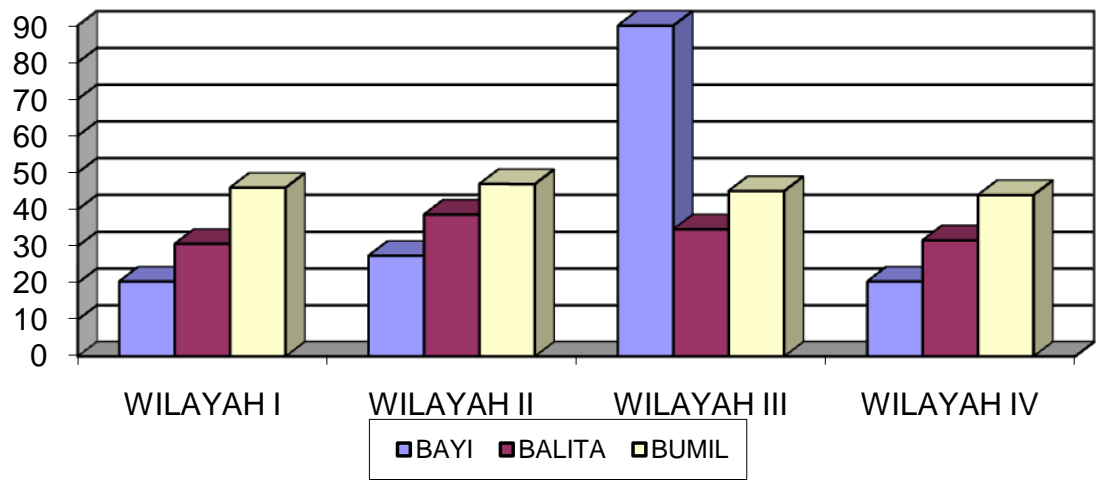

KUNJUNGAN KIA DI PUSKESMAS MULYO TAHUN 1995

b. Pie Diagram / Ven

Pie diagram merupakan bentuk penyajian berupa lingkaran yang dibagi berdasarkan proporsi kejadian terhadap keseluruhan. Lingkaran dibagi dalam sektor-sektor proporsi. Perhitungan luas sektor dengan cara mengalikan proporsi data dengan besaran sudut $360^{\circ}$. Dengan kata lain, dasar pembuatannya adalah tabel distribusi frekuensi relatif yang ditranfer dalam bentuk lingkaran. Jadi luasan sektor lingkaran yang menjadi area merupakan proporsi objek. Objek yang disajikan hanya satu variabel yang dirinci.

Contoh :

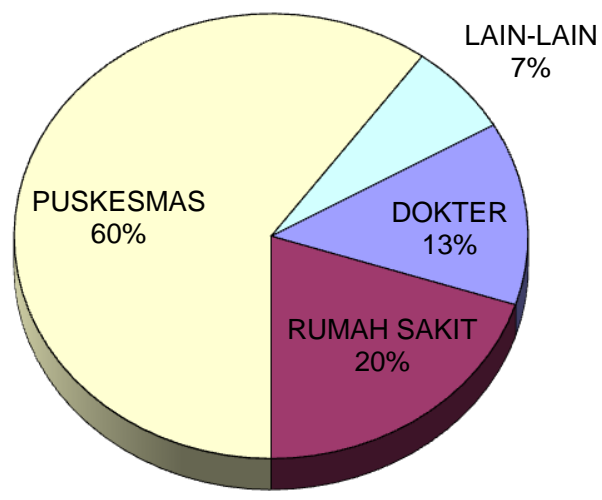

PILIHAN PELAYANAN PENGOBATAN PADA MASYARAKAT KEC TAWANG TAHUN 1995

Modifikasi bentuk diagram ven yang digabung dengan area batang sebagai penjelas. Contoh :

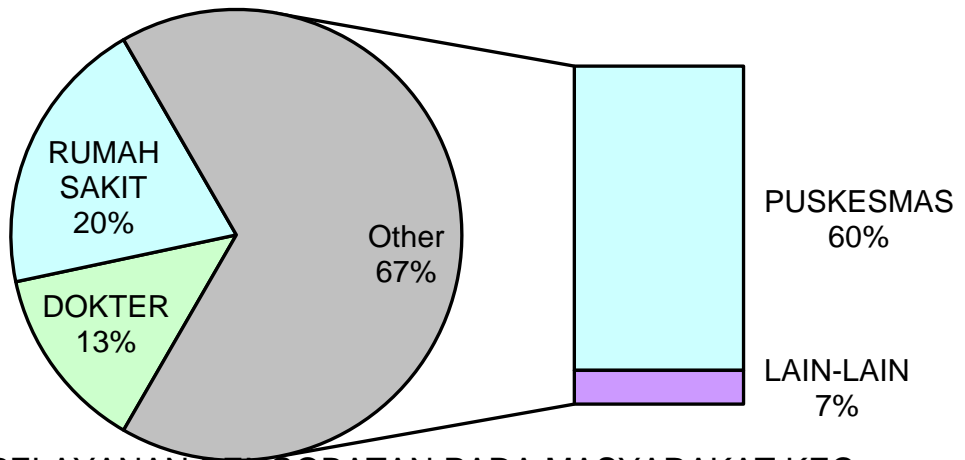

PILIHAN PELAYANAN PENGOBATAN PADA MASYARAKAT KEC

TAWANG TAHUN 1995 


\section{c. Dounat}

Penyajian bentuk dounat tidak berbeda dengan bentuk lingkaran, namun hanya bagian tepinya saja dan penyajiannya dapat bertumpuk, sehingga menyerupai kue donat. Jadi data yang disajikan dapat meliputi satu variabel yang dirinci, dan beberapa waktu, tempat, kondisi yang beda. Perbandingan antar luas area tidak diperhatikan, hanya besar sudut yang merupakan proporsi masing-masing variabel.

\section{Contoh :}

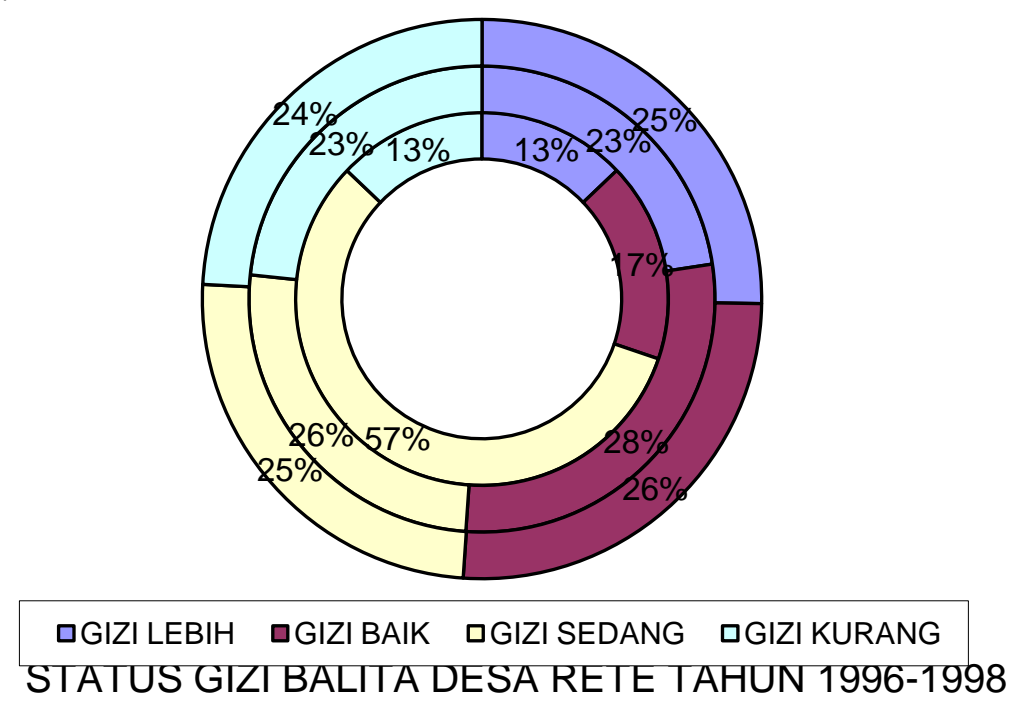

3. Gambar

a. Pictogram

Bentuk penyajian dengan cara menvisualisasikan satuan jumlah dengan gambar. Sebuah pictogram menyajikan data berupa gambar. Tiap gambar melambangkan/mewakili suatu jumlah tertentu. Data yang dapat disajikan hanya satu variabel yang dirinci.

Contoh :

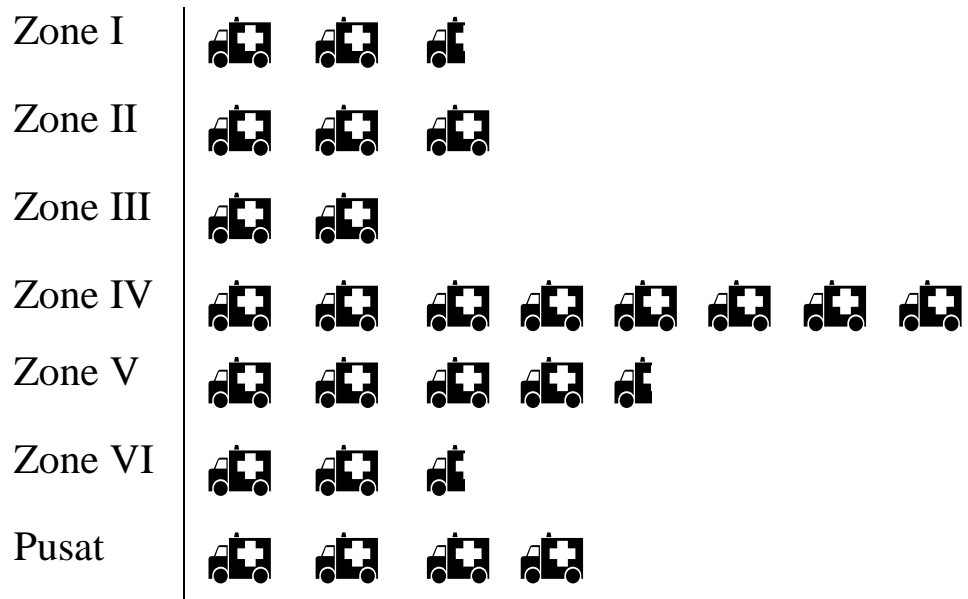

= mewakili 10 ambulans 
b. Peta

Penyajian dalam bentuk peta dimaksudkan untuk memberikan gambaran situasi lokasi suatu daerah secara singkat, jelas dan lengkap. Simbol-simbol objek yang ditampilkan pada peta tergantung kemuan pembuat dan informasi yang ingin disajikan. Simbol melambangkan kondisi wilayah yang sebenarnya. Selain simbol dapat juga disertakan angka yang dianggap penting dengan permsalahan yang ada. Contoh :

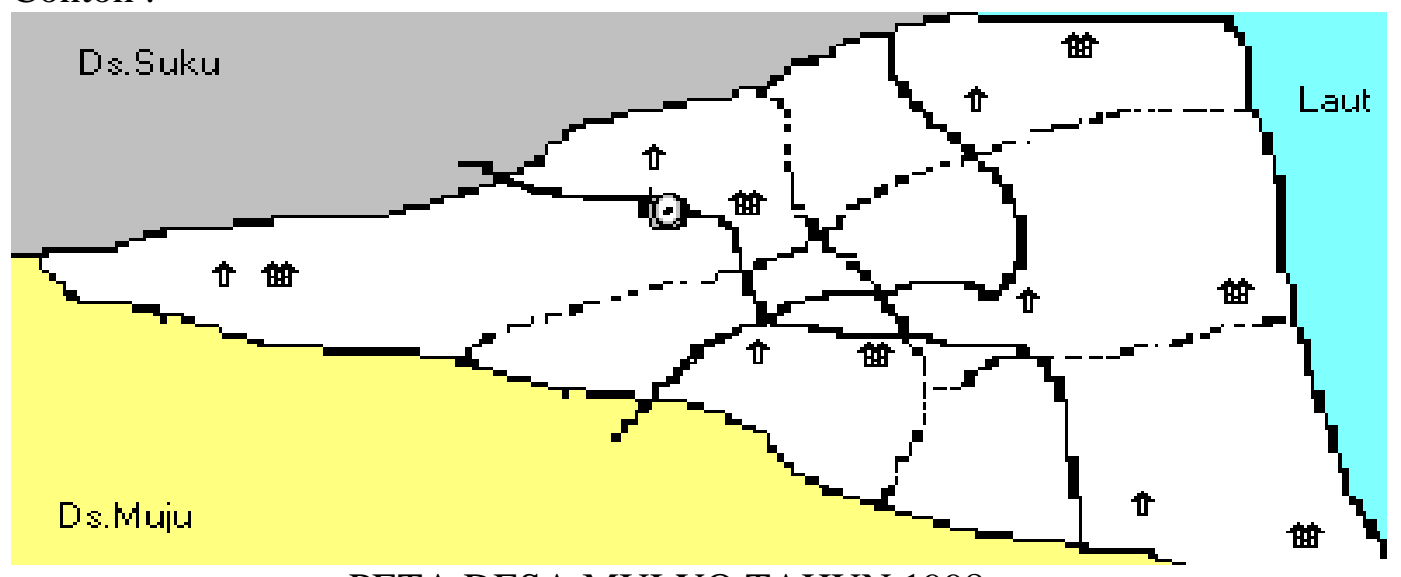

\section{PETA DESA MULYO TAHUN 1998}

Penyajian data dapat dilakukan tidak hanya satu jenis model penyajian saja, namun dapat dilakukan pengembangan variasi model, sehingga menarik untuk dilihat. Disamping penyajiannya yang sangat bagus, informasi data yang disampaikan mudah dimengerti konsumen. 


\section{BAB. V \\ ANALISIS DATA}

Analisis data merupakan kegiatan untuk merubah data menjadi seringkasnya, sehingga data tersebut dapat diwakili oleh satu angka. Angka tersebut sebagai patokan untuk keperluan analisis berikutnya. Angka yang didapatkan dari populasi lazim disebut sebagai parameter, sedangkan angka yang didapatkan dari sampel biasanya disebut statistik.

Pada analisis yang sederhana angka dapat langsung dibandingkan dengan standar atau ketentuan baku yang disepakati aturan, teori atau hukum. Pada analisis untuk mengeneralisasi populasi dari pengukuran sampel diperlukan langkah lebih lanjut, yaitu menggunakan uji statistik tertentu, untuk menarik suatu simpulan.

\section{A. Proporsi}

1. Angka Absolut

Angka absolut adalah angka yang sebenar keadaan fenomena karakteristik obyek.

\section{Rate}

Rate mengukur probabilitas terjadinya suatu peristiwa. Rate merupakan perbandingan antara jumlah suatu peristiwa dibagi oleh semua yang memiliki kemungkinan terkena peristiwa itu dikalikan konstanta. Bersarnya konstanta tergantung sesuai dengan kebutuhan analisis, misalnya per 1.000 , per 100.000 , dsb.

$$
\text { Rate }=\frac{X}{X+Y} \cdot K
$$

\section{Ratio}

Ratio adalah suatu pernyataan dari suatu hubungan pembilang dan penyebut atau dengan kata lain perbandingan antara jumlah suatu peristiwa dan jumlah peristiwa yang lain. Jadi hanya merupakan perbandingan biasa.

$$
\text { Ratio }=\frac{X}{Y}
$$

\section{Proporsi}

Proporsi adalah suatu pernyataan dimana pembilang selalu menjadi bagian dari penyebut, biasa disebut juga prosentase.

$$
\text { Proporsi }=\frac{X}{X+Y} \cdot 100 \%
$$

\section{B. Ukuran Tendensi Sentral}

Ukuran tendensi sentral meliputi modus (mode), median dan mean. Perhitungan modus, median dan mean merupakan perhitungan dasar untuk analisis lebih lanjut. Perhitungan modus, median dan mean terdiri dari dua jenis, yaitu untuk data yang belum dikelompokkan atau data mentah hasil pengukuran dan data yang telah dikelompokkan dalam tabel distribusi frekuensi.

1. Modus

Modus adalah angka yang sering muncul pada suatu data. Banyaknya modus pada suatu data mungkin tidak ada, mungkin satu, dua, tiga, empat atau lebih. Analisis modus cocok untuk data skala nominal. 
a. Modus data yang tidak berkelompok

Modus untuk data yang belum dikelompokkan cukup melihat angka paling sering muncul pada data tersebut.

Contoh :

2, 3, 3, 2, 4, 4, 3, 4, 5, 6, 4, 4, 5. Maka modusnya adalah 4

$2,4,3,5,5,2,3,6,6,5,4,4,3$. Maka modusnya adalah 3,4 , dan 5

b. Modus data yang berkelompok

Data yang sudah dikelompokkan menurut interval kelas, modus selalu terletak pada interval kelas yang memiliki frekuensi paling tinggi. Bila frekuensi tertinggi ada dua, maka modus juga ada dua (bimodus), bila modusnya lebih dari dua (multimodus).

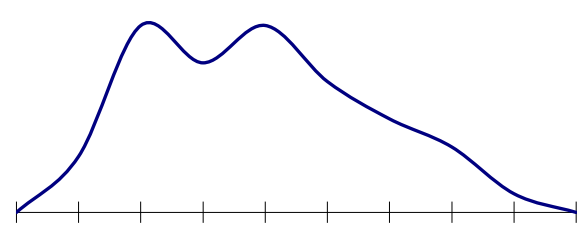

bimodus

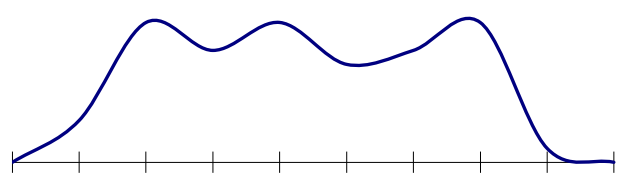

multimodus

Rumus modus untuk data yang sudah dikelompokkan ada dua macam, yaitu :

$M d o=L b+\frac{\Delta a}{\Delta a+\Delta b} . I$ atau menggunakan rumus $M d o=L a-\frac{\Delta b}{\Delta a+\Delta b} . I$

Keterangan:

$M d o=$ Modus

$L b \quad$ = batas bawah kelas modus

$L a \quad=$ batas atas kelas modus

$\Delta a$ = beda frekuensi pada kelas modus dengan frekuensi pada kelas yang lebih rendah didekatnya atau frekuensi sebelumnya

$\Delta b$ = beda frekuensi pada kelas modus dengan frekuensi pada kelas yang lebih tinggi di dekatnya atau frekuensi sesudahnya

I = lebar interval kelas

Kadang-kadang antara rumus pertama dengan rumus kedua menghasilkan angka yang berbeda, namun perbedaannya tidak terlalu besar.

Contoh :

TINGGI BADAN MASYARAKAT KALIMAS TAHUN 1990

\begin{tabular}{|c|c|c|}
\hline NO. & TINGGI BADAN & JUMLAH \\
\hline 1. & $140-149$ & 6 \\
\hline 2. & $150-159$ & 22 \\
\hline 3. & $160-169$ & 39 \\
\hline 4. & $170-179$ & 25 \\
\hline 5. & $180-189$ & 7 \\
\hline 6. & $190-199$ & 1 \\
\hline \multicolumn{2}{|c|}{} & 100 \\
\hline
\end{tabular}

Kelas dengan frekuensi tertinggi ( 39 ) adalah posisi modus, yaitu kelas ke 3 pada interval kelas 160 - 170. Jadi : 


$$
\begin{aligned}
& L b=159,5 \\
& L a=169,5 \\
& \Delta a=17 \\
& \Delta b=14 \\
& I \quad=10 \\
& M d o=L b+\frac{\Delta a}{\Delta a+\Delta b} \cdot I \\
& \text { Mdo }=159,5+\frac{17}{17+14} \cdot 10 \\
& \text { Mdo }=164,98 \\
& \text { atau menggunakan rumus } \\
& \text { Mdo }=\text { La }-\frac{\Delta b}{\Delta a+\Delta b} \cdot I \\
& \text { Mdo }=169,5-\frac{14}{17+14} .10 \\
& \text { Mdo }=164,98
\end{aligned}
$$

2. Median

Median adalah angka yang berada di tengah-tengah pada suatu data yang telah diurutkan (array) mulai dari angka terendah sampai tertinggi atau sebaliknya. Posisi median selalu didasarkan pada rumus $(\mathrm{N}+1) / 2$. Median biasanya dipergunakan untuk analisis data skala ordinal.

a. Median data yang tidak berkelompok

Bila banyaknya angka pada data ganjil, maka angka pada posisi median langsung didapatkan. Namun bila banyaknya angka pada data genap maka mediannya adalah angka yang berada di bawah posisi median dan di atas posisi median dijumlah dibagi dua.

Misal :

Banyaknya angka pada data ganjil. 2, 3, 2, 4, 5, 4, 5, 5, 6, 4, 3, 5, 4 untuk menentukan mediannya, disusun terlebih dahulu arraynya, yaitu 2, 2, 3, 3, 4, 4, 4, 4, 5, 5, 5, 5, 6 . Posisi median $(\mathrm{N}+1) / 2$, berarti $(13+1) / 2=7$, maka angka yang berada diurutan ke 7 adalah mediannya, yaitu 4 .

Banyaknya angka pada data genap. 4, 3, 5, 6, 4, 4, 5, 6, 7, 6, 3, 2 untuk menentukan mediannya, disusun terlebih dahulu arraynya, yaitu 2, 3, 3, 4, 4, 4, 5, 5, 6, 6, 6, 7. Posisi median $(\mathrm{N}+1) / 2$, berarti $(12+1) / 2=6,5$, maka angka yang berada diurutan ke 6 dan 7 dijumlahkan, kemudian dibagi dua, yaitu $(4+5) / 2=4,5$.

b. Median data yang berkelompok

Data yang telah tersusun dalam distribusi frekuensi dapat dicari dengan interpolasi, rumus yang digunakan ada dua macam, yaitu : 
$M d i=L b+\frac{\frac{N}{2}-F a}{f d} . I$ atau menggunakan rumus $M d i=L a-\frac{\frac{N}{2}-F b}{f d} . I$

Keterangan:

$M d i=$ Median

$L b$ = batas bawah kelas median

$L a \quad$ batas atas kelas median

$N=$ total frekuensi / banyaknya angka pada data

$F a=$ frekuensi komulatif sebelum frekuensi kelas median atau kelas lebih rendah

$F b=$ frekuensi komulatif sesudah frekuensi kelas median atau kelas lebih tinggi

$f d \quad=$ frekuensi pada kelas median

I = lebar interval

atau menggunakan gambar

Langkah yang perlu ditempuh dengan menyajikan data dalam bentuk histogram. Luasan histrogram dihitung dengan ketentuan lebar adalah interval kelas, sedangkan panjang adalah frekuensi. Luasan histogram dibagi menjadi dua luasan yang sama besar. Garis tengah yang memisahkan histogram menjadi dua luasan yang sama besar memotong sumbu $\mathrm{X}$ merupakan titik median.

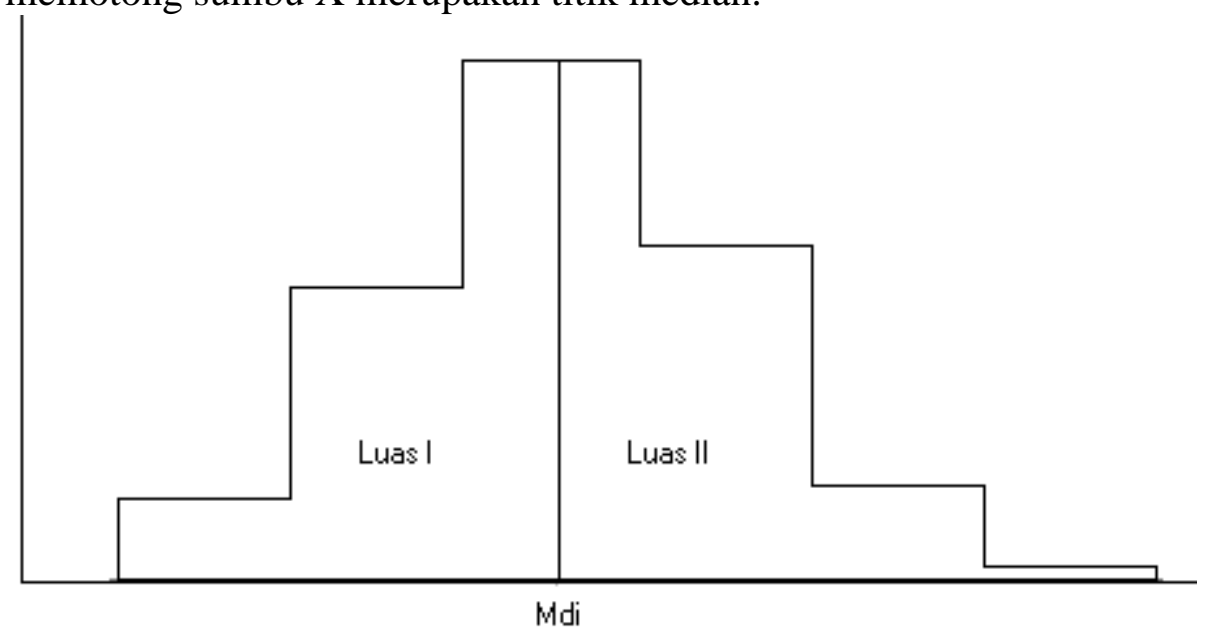

Contoh :

TINGGI BADAN MASYARAKAT KALIMAS TAHUN 1990

\begin{tabular}{|c|c|c|}
\hline NO. & TINGGI BADAN & JUMLAH \\
\hline 1. & $140-149$ & 6 \\
\hline 2. & $150-159$ & 22 \\
\hline 3. & $160-169$ & 39 \\
\hline 4. & $170-179$ & 25 \\
\hline 5. & $180-189$ & 7 \\
\hline 6. & $190-199$ & 1 \\
\hline \multicolumn{2}{|c|}{} \\
\hline
\end{tabular}

Langkah-langkah perhitungan median :

Tentukan posisi median dengan rumus $(\mathrm{N}+1) / 2=(100+1) / 2=50,5$, berarti pada kelas ke 3, maka :
$L b=159,5$
$L a=169,5$ 


$$
\begin{aligned}
N & =100 \\
F a & =28 \\
F b & =33 \\
f d & =39 \\
I & =10
\end{aligned}
$$

$M d i=L b+\frac{\frac{N}{2}-F a}{f d} . I$

$M d i=159,5+\frac{\frac{100}{2}-28}{39} .10$

$M d i=165,14$

Menggunakan rumus yang lain :

$M d i=L a-\frac{\frac{N}{2}-F b}{f d} . I$

$M d i=169,5-\frac{\frac{100}{2}-33}{39} .10$

$M d i=165,14$

Menggunakan gambar histogram

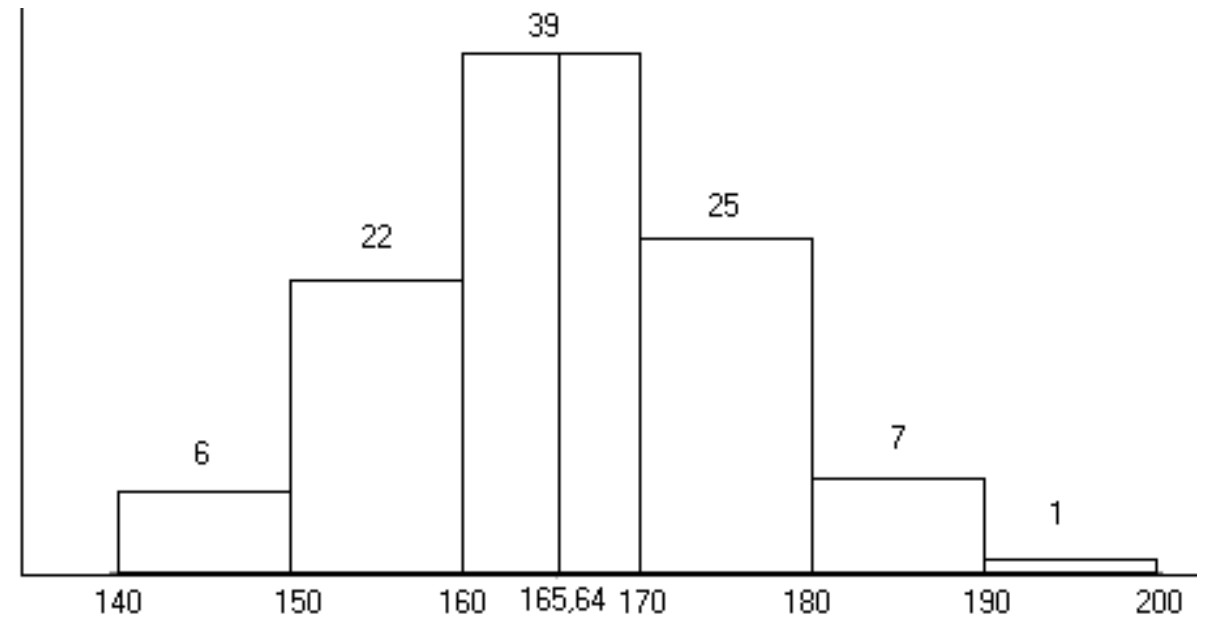

Berdasarkan gambar di atas luas histogram adalah $(6 \times 10)+(22 \times 10)+(39 \times 10)+$ $(25 \times 10)+(7 \times 10)+(1 \times 10)=1000$. Luasan dibagi menjadi dua bagian, berarti masing-masing luasan 500. Telah diketahui luasan batang $I=60$, batang II 220, luasan batang III $=390$, luasan batang IV $=250$, luasan batang $\mathrm{V}=70$ dan luasan batang VI $=10$. Luasan batang I ditambah luasan batang II berjumlah 280, yang berarti untuk menjadi luasan 500 masih kurang 220. Luasan 220 didapat pada luasan 
batang III, panjang batang III = 39, berarti lebar untuk mencapai luasan 220, luasan 220 dibagi lebar 39 didapat angka 5,64. Median berarti 159,5 sebagai batas bawah batang III ditambah 5,64 sama dengan 165,14.

Sejenis dengan perhitungan median adalah kuartil, desil dan persentil. Median membagi data menjadi dua bagian yang sama, kuartil membagi data menjadi empat bagian yang sama, desil membagi data menjadi sepuluh bagian yang sama dan persentil membagi data menjadi seratus bagain yang sama. Pada median hanya ada satu angka median, angka yang berada di tengah pada suatu data yang telah diurutkan (array) terlebih dahulu. Pada kuartil terdapat tiga angka, yaitu kuartil I, kuartil II dan kuartil III. Kuartil II sama dengan median, sedangkan kuartil I dan II dihitung dengan cara yang sama seperti menghitung median. Demikian juga untuk menghitung desil dan persentil.

Rentang Data

Median (Mdi) Mdi

Kuartil (Qi)

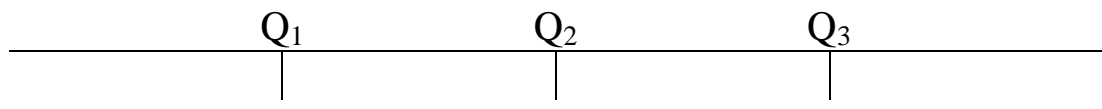

Decile (Di)

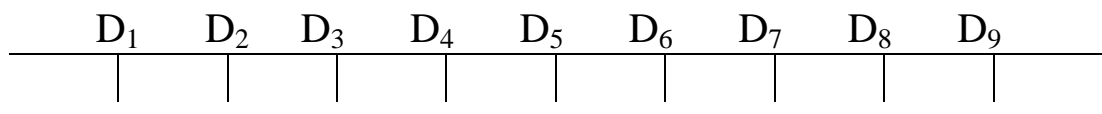

Percentile (Pi)

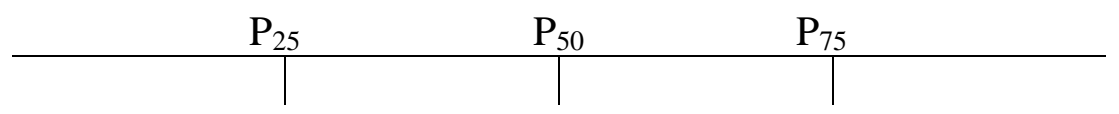

$Q_{i}=L b_{i}+\frac{i \cdot \frac{N}{4}-F a_{i}}{f_{Q i}} . I$ atau menggunakan rumus $Q_{i}=L a_{i}-\frac{i \cdot \frac{N}{4}-F b_{i}}{f_{Q i}} . I$

$D_{i}=L b_{i}+\frac{i \cdot \frac{N}{10}-F a_{i}}{f_{D i}} . I$ atau menggunakan rumus $D_{i}=L a_{i}-\frac{i \cdot \frac{N}{10}-F b_{i}}{f_{D i}} . I$

$P_{i}=L b_{i}+\frac{i \cdot \frac{N}{100}-F a_{i}}{f_{P i}} . I$ atau menggunakan rumus $P_{i}=L a_{i}-\frac{i \cdot \frac{N}{100}-F b_{i}}{f_{P i}} . I$

Keterangan:

$i=$ urutan deret ke 1, 2, 3, 4, dst.

$Q_{i} \quad=$ kuartile ke i

$D_{i}=$ decile ke i

$P_{i} \quad=$ persentile ke $\mathrm{i}$

$L b_{i}=$ batas bawah kelas ke $\mathrm{i}$

$L a_{i}=$ batas atas kelas ke i

$N=$ total frekuensi / banyaknya angka pada data

$F a_{i}=$ frekuensi komulatif sesudah frekuensi kelas ke i atau kelas lebih rendah

$F b_{i}=$ frekuensi komulatif sebelum frekuensi kelas ke i atau kelas lebih tinggi 
$f \quad=$ frekuensi pada kelas i atau frekuensi letak angka yang dicari

I = lebar interval

Langkah pertama penggunaan rumus di atas, yaitu menentukan terlebih dahulu posisi kelas letak kuartile, decile, percentile yang akan dicari. Cara menentukan posisi kelas dengan rumus $i\left(\frac{N+1}{4}\right)$ untuk kuartile, $i\left(\frac{N+1}{10}\right)$ untuk decile, $i\left(\frac{N+1}{100}\right)$ untuk percentile. Kemudian faktor lain yang terdapat pada rumus dicari.

3. Mean

Mean biasa diterjemahkan dengan rata-rata atau rerata. Mean dilambangkan dengan tanda $\mathrm{X}$ yang diberi garis di atasnya $(\bar{X})$ biasa disebut $\mathrm{X}$ bar. Pada mean suatu populasi biasa dilambangan dengan $\mu$, sedangkan untuk sampel dilambangkan $\bar{X}$. Mean merupakan angka yang dapat mewakili suatu data untuk ukuran tendency central.

a. Mean data yang tidak berkelompok

Mean biasa dirumuskan dengan jumlah seluruh angka yang ada pada data dibagi dengan banyaknya angka pada data, dengan notasi rumus sebagai berikut :

$\bar{X}=\frac{\sum X_{i}}{N}$ atau menggunakan rumus $\bar{X}=\overline{X_{d}}+\frac{\sum d_{i}}{N}$.

Keterangan:

$\bar{X} \quad=$ rata-rata

$X_{i} \quad$ angka anggota data

$N$ = banyaknya angka pada data

$\overline{X_{d}}$ =angka yang diduga sebagai rata-rata (guess mean)

$d_{i}=$ selisih antara rata-rata yang diduga dengan angka anggota data $\left(X_{i}-\overline{X_{d}}\right)$

Contoh :

$35,45,36,42,38,36,48,38,40,34,34$

$$
\begin{aligned}
& \bar{X}=\frac{\sum X_{i}}{N} \\
& \bar{X}=\frac{35+45+36+42+38+36+48+38+40+34+34}{11} \\
& \bar{X}=38,73
\end{aligned}
$$

atau menggunakan rumus $\bar{X}=\overline{X_{d}}+\frac{\sum d_{i}}{N}$

misalnya yang diduga sebagai rata-rata angka 36, maka 


\begin{tabular}{|c|c|c|c|}
\hline NOMOR & ANGKA $\left(X_{i}\right)$ & YANG DIDUGA $\left(\overline{X_{d}}\right)=36$ & $d_{i}=X_{i}-36$ \\
\hline 1. & 35 & & -1 \\
\hline 2. & 45 & & +9 \\
\hline 3. & 36 & & 0 \\
\hline 4. & 42 & & +6 \\
\hline 5. & 38 & & +2 \\
\hline 6. & 36 & & 0 \\
\hline 7. & 48 & & +12 \\
\hline 8. & 38 & & +2 \\
\hline 9. & 40 & & +4 \\
\hline 10. & 34 & & -2 \\
\hline 11. & 34 & & -2 \\
\hline & JUMLAH & & +30 \\
\hline
\end{tabular}

$\bar{X}=\overline{X_{d}}+\frac{\sum d_{i}}{N}$

$\bar{X}=36+\frac{30}{11}$

$\bar{X}=38,73$

misalnya yang diduga sebagai rata-rata 40 , maka

\begin{tabular}{|c|c|c|c|}
\hline NOMOR & ANGKA $\left(X_{i}\right)$ & YANG DIDUGA $\left(\overline{X_{d}}\right)=40$ & $d_{i}=X_{i}-40$ \\
\hline 1. & 35 & & -5 \\
\hline 2. & 45 & & +5 \\
\hline 3. & 36 & & -4 \\
\hline 4. & 42 & & +2 \\
\hline 5. & 38 & & -2 \\
\hline 6. & 36 & & -4 \\
\hline 7. & 48 & & +8 \\
\hline 8. & 38 & & -2 \\
\hline 9. & 40 & & 0 \\
\hline 10. & 34 & & -6 \\
\hline 11. & 34 & & -6 \\
\hline \multicolumn{2}{|r|}{ JUMLAH } & & -14 \\
\hline
\end{tabular}

$\bar{X}=\overline{X_{d}}+\frac{\sum d_{i}}{N}$

$\bar{X}=40+\left(\frac{-14}{11}\right)$

$\bar{X}=38,73$

b. Mean data yang berkelompok

Data yang telah tersusun pada tabel distribusi frekuensi menggunakan rumus sebagai berikut : 
$\bar{X}=\frac{\sum f_{i} \cdot X_{i}}{N}$ atau menggunakan rumus $\bar{X}=\overline{X_{d}}+\frac{\sum f_{i} \cdot d_{i}}{N}$ atau menggunakan rumus $\bar{X}=\overline{X_{d}}+\frac{\sum f_{i} \cdot U_{i}}{N} . I$

Keterangan:

$\bar{X}=$ rata-rata

$f_{i} \quad=$ frekuensi

$X_{i}=$ titik tengah interval kelas (batas bawah kelas $+1 / 2$ lebar interval kelas)

$N$ = banyaknya angka pada data (total frekuensi)

$\overline{X_{d}}=$ Angka (titik tengah interval kelas) yang diduga sebagai rata-rata (guess mean)

$d_{i} \quad=$ selisih antara rata-rata yang diduga dengan titik tengah interval kelas $\left(X_{i}-\overline{X_{d}}\right)$

$U_{i} \quad=$ working unit $\left(\frac{d_{i}}{I}\right)$

I = lebar interval kelas

Contoh :

TINGGI BADAN MASYARAKAT KALIMAS TAHUN 1990

\begin{tabular}{|c|c|c|}
\hline NO. & TINGGI BADAN & JUMLAH \\
\hline 1. & $140-149$ & 6 \\
\hline 2. & $150-159$ & 22 \\
\hline 3. & $160-169$ & 39 \\
\hline 4. & $170-179$ & 25 \\
\hline 5. & $180-189$ & 7 \\
\hline 6. & $190-199$ & 1 \\
\hline \multicolumn{2}{|r|}{ JUMLAH } & 100 \\
\hline
\end{tabular}

Menggunakan rumus $\bar{X}=\frac{\sum f_{i} \cdot X_{i}}{N}$

\begin{tabular}{|c|c|c|c|c|}
\hline NO. & TINGGI BADAN & $\operatorname{JUMLAH~}\left(f_{i}\right)$ & $X_{i}$ & $f_{i} \cdot X_{i}$ \\
\hline 1. & $140-149$ & 6 & 144,5 & 867,0 \\
\hline 2. & $150-159$ & 22 & 154,5 & 3399,0 \\
\hline 3. & $160-169$ & 39 & 164,5 & 6415,5 \\
\hline 4. & $170-179$ & 25 & 174,5 & 4362,5 \\
\hline 5. & $180-189$ & 7 & 184,5 & 1291,5 \\
\hline 6. & $190-199$ & 1 & 194,5 & 194,5 \\
\hline \multicolumn{2}{|r|}{ JUMLAH } & 100 & & 16530,0 \\
\hline
\end{tabular}

$\bar{X}=\frac{16530}{100}$

$\bar{X}=165,30$ 
Menggunakan rumus $\bar{X}=\overline{X_{d}}+\frac{\sum f_{i} \cdot d_{i}}{N}$, misalnya mean yang diduga 175

\begin{tabular}{|c|c|c|c|c|c|}
\hline NO. & TINGGI BADAN & JUMLAH $\left(f_{i}\right)$ & $X_{i}$ & $d_{i}=X_{i}-175$ & $f_{i} \cdot d_{i}$ \\
\hline 1. & $140-149$ & 6 & 144,5 & $-30,5$ & $-183,0$ \\
\hline 2. & $150-159$ & 22 & 154,5 & $-20,5$ & $-451,0$ \\
\hline 3. & $160-169$ & 39 & 164,5 & $-10,5$ & $-409,5$ \\
\hline 4. & $170-179$ & 25 & 174,5 & $-0,5$ & $-12,5$ \\
\hline 5. & $180-189$ & 7 & 184,5 & 9,5 & 66,5 \\
\hline 6. & $190-199$ & 1 & 194,5 & 19,5 & 19,5 \\
\hline \multicolumn{2}{|r|}{ JUMLAH } & 100 & & & $-970,0$ \\
\hline
\end{tabular}

$\bar{X}=175+\left(\frac{-970}{100}\right)$

$\bar{X}=165,30$

Menggunakan rumus $\bar{X}=\overline{X_{d}}+\frac{\sum f_{i} \cdot U_{i}}{N} . I$, misalnya mean yang diduga 165

\begin{tabular}{|c|c|r|r|r|r|r|}
\hline NO. & TINGGI BADAN & JUMLAH $\left(f_{i}\right)$ & $X_{i}$ & $d_{i}=X_{i}-165$ & $U_{i}=\left(\frac{d_{i}}{I}\right)$ & $f_{i} \cdot U_{i}$ \\
\hline 1. & $140-149$ & 6 & 144,5 & $-20,5$ & $-2,05$ & $-12,30$ \\
\hline 2. & $150-159$ & 22 & 154,5 & $-10,5$ & $-1,05$ & $-23,10$ \\
\hline 3. & $160-169$ & 39 & 164,5 & $-0,5$ & $-0,05$ & $-1,95$ \\
\hline 4. & $170-179$ & 25 & 174,5 & 9,5 & 0,95 & 23,75 \\
\hline 5. & $180-189$ & 7 & 184,5 & 19,5 & 1,95 & 13,65 \\
\hline 6. & $190-199$ & 1 & 194,5 & 29,5 & 2,95 & 2,95 \\
\hline \multicolumn{2}{|c|}{ JUMLAH } & 100 & & & & 3,00 \\
\hline
\end{tabular}

$\bar{X}=165+\frac{3}{100} \cdot 10$
$\bar{X}=165,30$

Secara empirik modus, median dan mean memiliki hubungan matematis sebagai berikut ;

$\mid$ Modus - Mean $|=3|$ Mean - Median $\mid$

Aplikasi ukuran tendency pada distribusi data dapat memperlihatkan kemencengan (skewness) seperti pada kurva di bawah ini.

Kemencengan ke kanan.

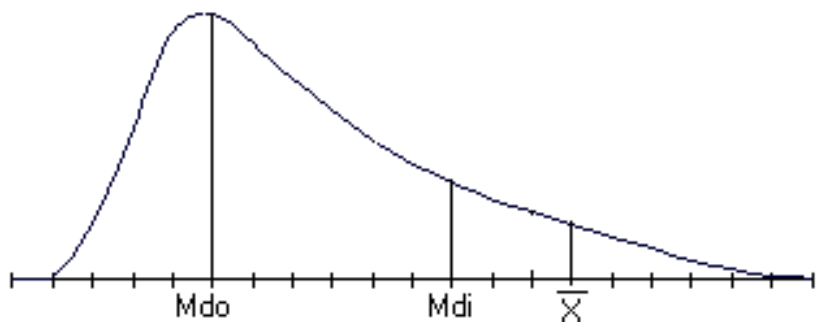


Kemencengan ke kiri.

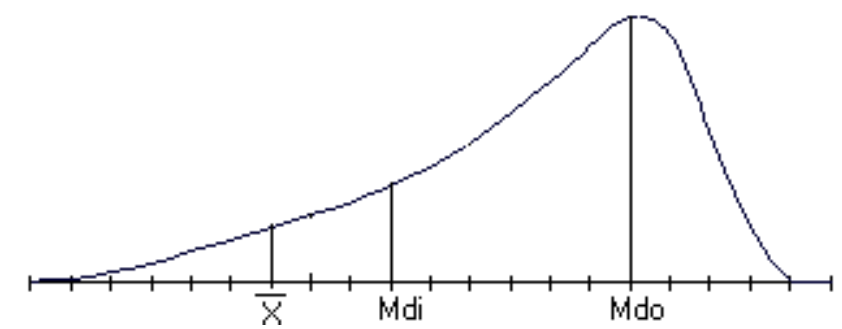

Kurva normal.

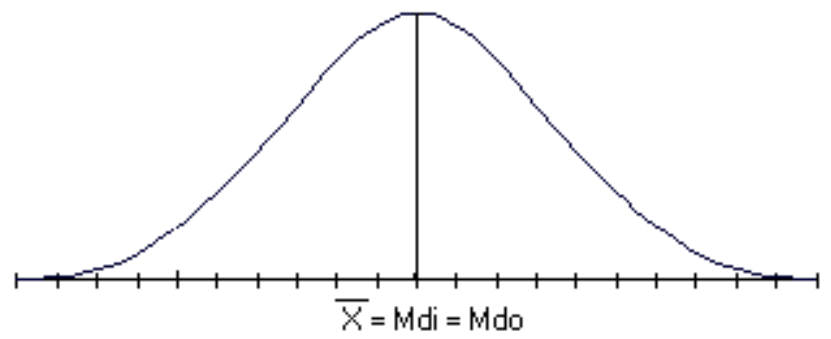

C. Variability

1. Rentang

Rentang adalah perbedaan angka yang tertinggi dan angka yang terendah pada suatu data.

Rentang merupakan suatu analisis deviasi yang paling sederhana, hanya mengetahui kisaran angka pada data. Rentang biasa dirumuskan :

$\mathrm{R}=\mathrm{A}_{\mathrm{tt}}-\mathrm{A}_{\mathrm{tr}}$ ada juga menambah rumus tersebut dengan angka 1.

Contoh :

Kelompok I ; 35, 45, 36, 42, 38, 36, 48, 38, 40, 34, 34, maka rentang data tersebut adalah $48-34=14$.

Kelompok II ; 36, 34, 50, 32, 46, 34, 38, 44, 48, 44, 56, maka rentang data tersebut 56 $32=24$.

Berdasarkan keadaan tersebut di atas keadaan data kelompok II lebih menyebar memanjang daripada kelompok I yang kondisinya lebih mengumpul.

Rentang untuk data yang berkelompok adalah batas atas kelas yang paling besar dikurangi batas bawah kelas yang paling rendah.

2. Deviasi rata-rata

Deviasi rata-rata adalah rata-rata penyimpangan tiap angka pada suatu data terhadap meannya. Makin kecil harga deviasi ini, berarti makin kecil dispersi (pemencaran) angka pada data tersebut terhadap meannya.

a. Deviasi rata-rata data yang tidak berkelompok

Deviasi rata-rata pada data yang tidak berkelompok dirumuskan sebagai berikut :

$$
D r=\frac{\sum\left|X_{i}-\bar{X}\right|}{N}
$$

Keterangan: 
$D r=$ deviasi rata-rata

$\bar{X}=$ rata-rata

$X_{i} \quad=$ angka anggota data

$N$ = banyaknya angka pada data

Contoh :

Kelompok I ; 35, 45, 36, 42, 38, 36, 48, 38, 40, 34, 34, Kelompok II ; 36, 34, 50, 32, 46, 34, 38, 44, 48, 44, 56,

\begin{tabular}{|r|r|r|r|r|}
\hline \multirow{2}{*}{ NOMOR } & \multicolumn{2}{|c|}{ KELOMPOK I } & \multicolumn{2}{|c|}{ KELOMPOK II } \\
\cline { 2 - 5 } & $X_{1}$ & $\left|X_{1}-\bar{X}\right|$ & $X_{2}$ & $\left|X_{2}-\bar{X}\right|$ \\
\hline 1. & 35 & 3,73 & 36 & 2,73 \\
\hline 2. & 45 & 6,27 & 34 & 4,73 \\
\hline 3. & 36 & 2,73 & 50 & 11,27 \\
\hline 4. & 42 & 3,27 & 32 & 6,73 \\
\hline 5. & 38 & 0,73 & 46 & 7,27 \\
\hline 6. & 36 & 2,73 & 34 & 4,73 \\
\hline 7. & 48 & 9,27 & 38 & 0,73 \\
\hline 8. & 38 & 0,73 & 44 & 5,27 \\
\hline 9. & 40 & 1,27 & 48 & 9,27 \\
\hline 10. & 34 & 4,73 & 44 & 5,27 \\
\hline 11. & 34 & 4,73 & 56 & 17,27 \\
\hline JUMLAH & 426 & 40,19 & 462 & 75,27 \\
\hline MEAN & 38,73 & 3,65 & 42 & 6,84 \\
\hline
\end{tabular}

$D r=\frac{\sum\left|X_{i}-\bar{X}\right|}{N}$

Kelompok I ; Dr $=\frac{40,19}{11} ; D r=3,65$

Kelompok II ; Dr $=\frac{75,27}{11} ; D r=6,84$

Berdasarkan keadaan deviasi rata-rata data tersebut di atas dapat dilakukan analisis, bahwa data kelompok I lebih mengumpul ke arah meannya daripada data kelompok kedua yang menyebar terhadap meannya.

b. Deviasi rata-rata data yang berkelompok

$$
D r=\frac{\sum f_{i}\left|X_{i}-\bar{X}\right|}{N}
$$

Keterangan: 
$D r=$ deviasi rata-rata

$f_{i} \quad$ frekuensi

$\bar{X}=$ rata-rata

$X_{i}=$ titik tengah interval kelas (batas bawah kelas $+1 / 2$ lebar interval kelas)

$N$ = banyaknya angka pada data / total frekuensi

Contoh :

TINGGI BADAN MASYARAKAT KALIMAS TAHUN 1990

\begin{tabular}{|c|c|c|}
\hline NO. & TINGGI BADAN & JUMLAH \\
\hline 1. & $140-149$ & 6 \\
\hline 2. & $150-159$ & 22 \\
\hline 3. & $160-169$ & 39 \\
\hline 4. & $170-179$ & 25 \\
\hline 5. & $180-189$ & 7 \\
\hline 6. & $190-199$ & 1 \\
\hline \multicolumn{2}{|c|}{} & 100 \\
\hline
\end{tabular}

Diketahui rata-rata $=165,30$

\begin{tabular}{|l|c|r|r|r|r|}
\hline No & TB & JML $\left(f_{i}\right)$ & $X_{i}$ & $\left|X_{i}-\bar{X}\right|$ & \multicolumn{1}{|c|}{$f_{i}|X i-\bar{X}|$} \\
\hline 1. & $140-149$ & 6 & 144,5 & 20,8 & 124,80 \\
\hline 2. & $150-159$ & 22 & 154,5 & 10,8 & 237,60 \\
\hline 3. & $160-169$ & 39 & 164,5 & 0,8 & 31,20 \\
\hline 4. & $170-179$ & 25 & 174,5 & 9,2 & 230,00 \\
\hline 5. & $180-189$ & 7 & 184,5 & 19,2 & 134,40 \\
\hline 6. & $190-199$ & 1 & 194,5 & 29,2 & 29,20 \\
\hline & Jumlah & 100 & & & 787,20 \\
\hline
\end{tabular}

$D r=\frac{\sum f_{i} \cdot X_{i}-\bar{X} \mid}{N}$

$\operatorname{Dr}=\frac{787,2}{100}$

$\operatorname{Dr}=7,872$

3. Variansi

Variansi adalah harga deviasi yang juga memperhitungkan deviasi tiap data terhadap meannya. Variansi untuk populasi biasanya dilambangkan $\tau$, sedangkan vraiansi untuk sampel dilambangkan $\mathrm{S}^{2}$.

a. Variansi data yang tidak berkelompok

Variansi data yang tidak berkelompok menggunakan rumus $V=\frac{\sum\left(X_{i}-\bar{X}\right)^{2}}{N}$ atau rumus $V=\frac{\sum X_{i}^{2}}{N}-\left(\frac{\sum X_{i}}{N}\right)^{2}$ atau rumus $V=\frac{\sum X_{i}^{2}}{N}-\bar{X}^{2}$. 
Keterangan:

$V=$ variansi

$\bar{X}=$ rata-rata

$X_{i} \quad=$ angka anggota data

$N$ = banyaknya angka pada data

Contoh :

$35,45,36,42,38,36,48,38,40,34,34$

\begin{tabular}{|c|c|c|r|r|}
\hline NOMOR & $X_{i}$ & $X_{i}^{2}$ & $X_{i}-\bar{X}$ & $\left(X_{i}-\bar{X}\right)^{2}$ \\
\hline 1. & 35 & 1.225 & $-3,73$ & 13,91 \\
\hline 2. & 45 & 2.025 & 6,27 & 39,31 \\
\hline 3. & 36 & 1.296 & $-2,73$ & 7,45 \\
\hline 4. & 42 & 1.764 & 3,27 & 10,69 \\
\hline 5. & 38 & 1.444 & $-0,73$ & 0,53 \\
\hline 6. & 36 & 1.296 & $-2,73$ & 7,45 \\
\hline 7. & 48 & 2.304 & 9,27 & 85,93 \\
\hline 8. & 38 & 1.444 & $-0,73$ & 0,53 \\
\hline 9. & 40 & 1.600 & 1,27 & 1,61 \\
\hline 10. & 34 & 1.156 & $-4,73$ & 22,37 \\
\hline 11. & 34 & 1.156 & $-4,73$ & 22,37 \\
\hline JUMLAH & 426 & 16.710 & $-0,03$ & 212,18 \\
\hline MEAN & 38,73 & & & \\
\hline
\end{tabular}

$V=\frac{\sum\left(X_{i}-\bar{X}\right)^{2}}{N}$

$V=\frac{212,18}{11}$

$V=19,29$

atau menggunakan rumus $V=\frac{\sum X_{i}^{2}}{N}-\left(\frac{\sum X_{i}}{N}\right)^{2}$

$V=\frac{16710}{11}-\left(\frac{426}{11}\right)^{2}$

$V=19,29$

atau menggunakan rumus $V=\frac{\sum X_{i}^{2}}{N}-\bar{X}^{2}$

$V=\frac{16710}{11}-38,73^{2}$

$V=19,29$ 
b. Variansi data yang berkelompok

Perhitungan variansi untuk data yang berkelompok dapat menggunakan rumus

$$
V=\frac{\sum f_{i} \cdot\left(X_{i}-\bar{X}\right)^{2}}{N} \text { atau } V=\frac{\sum f_{i} \cdot X_{i}^{2}}{N}-\left(\frac{\sum f_{i} \cdot X_{i}}{N}\right)^{2} \text { atau } V=\frac{\sum f_{i} \cdot X_{i}^{2}}{N}-\bar{X}^{2}
$$

Keterangan:

$V \quad=$ variansi

$\bar{X}=$ rata-rata

$f_{i}=$ frekuensi

$X_{i}=$ titik tengah interval kelas (batas bawah kelas $+1 / 2$ lebar interval kelas)

$N=$ banyaknya angka pada data (total frekuensi)

Contoh :

TINGGI BADAN MASYARAKAT KALIMAS TAHUN 1990

\begin{tabular}{|c|c|c|}
\hline NO. & TINGGI BADAN & JUMLAH \\
\hline 1. & $140-149$ & 6 \\
\hline 2. & $150-159$ & 22 \\
\hline 3. & $160-169$ & 39 \\
\hline 4. & $170-179$ & 25 \\
\hline 5. & $180-189$ & 7 \\
\hline 6. & $190-199$ & 1 \\
\hline \multicolumn{2}{|c|}{} & JUMLAH \\
\hline
\end{tabular}

Diketahui rata-rata $=165,30$

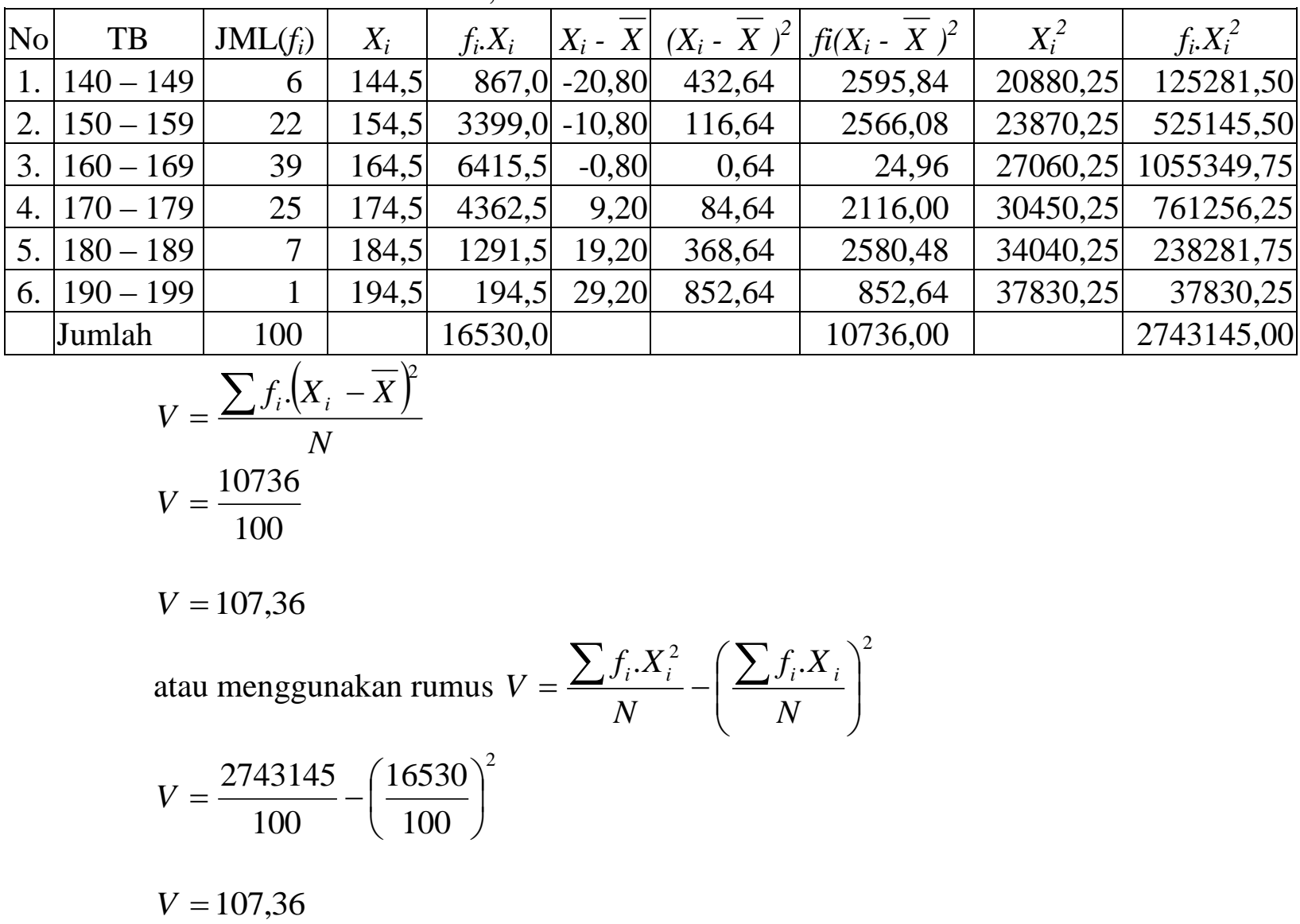




$$
\begin{aligned}
& \text { atau menggunakan rumus } V=\frac{\sum f_{i} \cdot X_{i}^{2}}{N}-\bar{X}^{2} \\
& V=\frac{2743145}{100}-165,3^{2} \\
& V=107,36
\end{aligned}
$$

4. Standar deviasi

Standar deviasi atau simpangan baku merupakan akar dari variansi. Standar deviasi dapat dipergunakan sebagai angka yang mewakili seluruh agregate untuk ukuran variability, dipengaruhi oleh perubahan nilai observasi. Standar deviasi biasa disingkat SD untuk ukuran sampel, sedangkan standar deviasi untuk populasi biasa dilambangkan $\sigma$ dan standar deviasi untuk sampel biasa dilambangkan S.

$$
S D=\sqrt{V}
$$

Kondisi yang perlu diketahui sehubungan dengan standar deviasi adalah dalam suatu distribusi frekuensi yang simetrik berdistribusi normal luas yang dibatasi nilai $\bar{X} \pm 1 \mathrm{SD}$ terdapat $68,3 \%$ jumlah observasi, yang dibatasi nilai $\bar{X} \pm 2$ SD terdapat 95,4\% jumlah observasi, yang dibatasi nilai $\bar{X} \pm 3$ SD terdapat $99,7 \%$ jumlah observasi.

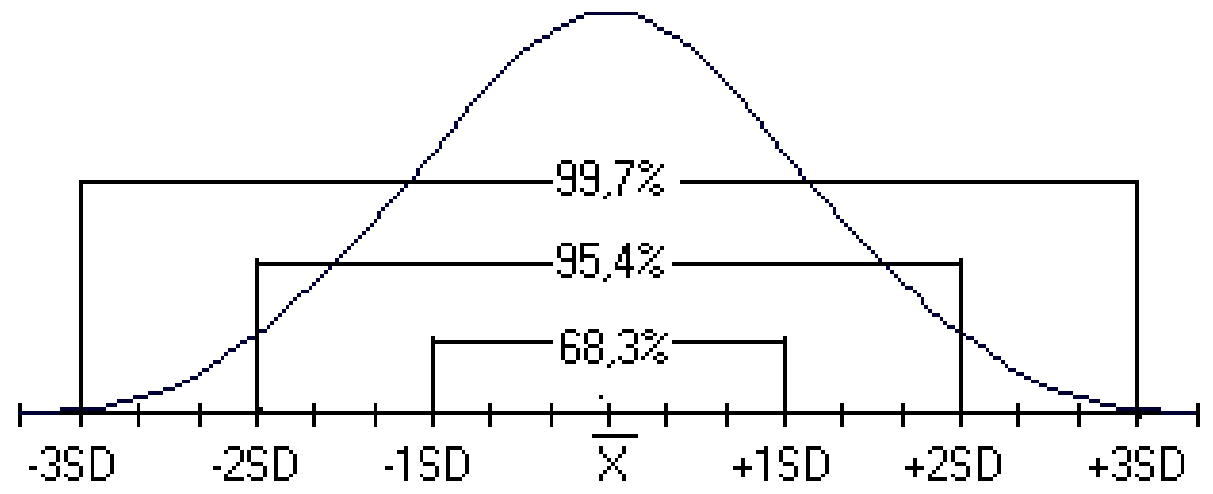

Proporsi luasan tersebut di atas secara rincinya dapat dilihat pada tabel distribusi normal.

5. Koefisien keragaman (Coefficien of Variation)

$C O V=\frac{S D}{\bar{X}} \cdot 100$

Contoh :

Kelompok I tinggi badan wanita $\bar{X}=157 \mathrm{~cm} ; \mathrm{SD}=2,4 \mathrm{~cm}$

Kelompok II tinggi badan pria $\bar{X}=172 \mathrm{~cm} ; \mathrm{SD}=4,8 \mathrm{~cm}$

COV Kelompok $\mathrm{I}=\frac{2,4}{157} \cdot 100 \%=1,53 \%$

COV Kelompok II $=\frac{4,8}{172} \cdot 100 \%=2,79 \%$

Berdasarkan hitungan COV tersebut dapat dianalisis bahwa kondisi kelompok II data lebih bervariasi daripada kelompok I. 


\section{BAB VI \\ SIMPULAN}

Kegiatan statistik analitik yang paling akhir adalah menyimpulkan data yang telah dianalisis. Kegiatan menarik simpulan ini sangat penting, karena keadaan populasi dapat diketahui berdasarkan generalisasi dari sampel yang dianalisis. Langkah-langkah menarik simpulan secara umum ada delapan, yaitu : membuat hipotesis, menentukan nilai signifikansi $(\alpha)$, menentukan rumus statistik penguji, menghitung nilai statistik penguji dan menentukan nilai kategori untuk uji hubungan, menentukan degree of freedom (df)/ derajat bebas (db)/ derajat kebebasan (dk), menentukan nilai kritis / nilai tabel, gambar daerah penolakan dan membuat keputusan simpulan. Penjelasan secara umum masing-masing langkah sebagai berikut :

\section{A. Hipotesis}

Hipotesis berasal dari kata hipo dan tesa, hipo artinya rendah atau di bawah, sedangkan tesa artinya pernyataan atau kebenaran. Jadi hipotesis artinya pernyataan kebenaran yang masih rendah, untuk itu hipotesis perlu dilakukan uji. Biasanya hipotesis dirumuskan dengan Ho sebagai dugaan awal setelah kita meninjau permasalahan penelitian. Sebagai tandingan Ho adalah hipotesis alternatif (Ha). Ha selalu berlawanan dengan Ho. Pernyataan yang tertulis pada Ho selalu negatif (menggunakan kata tidak), sebaliknya pernyataan pada Ha selalu positif.

Uji statistik hanya menguji Ho saja. Bila Ho diterima, maka secara otomatis Ha ditolak, demikian juga sebaliknya bila Ho ditolak maka Ha diterima.

Jenis-jenis hipotesis secara matematis yang sering digunakan adalah sebagai berikut :

1. Hipotesis mengandung perngertian sama

a. Ho: $\mu=\mu_{0}$ vs $\mathrm{Ha}: \mu=\mu_{1}$

b. Ho: $\mu_{1}=\mu_{0}$ vs $\mathrm{Ha}: \mu_{1} \neq \mu_{0}$

c. Ho: $\mu_{1}=\mu_{0}$ vs $\mathrm{Ha}: \mu_{1}>\mu_{0}$

d. Ho $: \mu_{1}=\mu_{0}$ vs $\mathrm{Ha}: \mu_{1}<\mu_{0}$

2. Hipotesis mengandung pengertian maksimum, yang dinamakan komposit lawan komposit.

Ho : $\mu_{1} \leq \mu_{0}$ vs $\mathrm{Ha}: \mu_{1}>\mu_{0}$

3. Hipotesis mengandung pengertian minimum, yang dinamakan komposit lawan komposit. Ho $: \mu_{1} \geq \mu_{0}$ vs $\mathrm{Ha}: \mu_{1}<\mu_{0}$

Pasangan Ho dan Ha yang kita pelajari yaitu berbentuk :

1. Ho: $\mu_{1}=\mu_{0}$ vs Ha: $\mu_{1} \neq \mu_{0}$ untuk uji dua sisi/pihak/ekor. Pernyataan untuk Ho adalah tidak ada perbedaan antara $\mu_{1}$ dan $\mu_{0}$, sedangkan Ha adalah ada perbedaan antara $\mu_{1}$ dan $\mu_{0}$.

2. Ho : $\mu_{1}=\mu_{0}$ vs $\mathrm{Ha}: \mu_{1}>\mu_{0}$ untuk uji satu sisi/pihak/ekor sebelah kanan positif. Pernyataan untuk Ho adalah tidak ada perbedaan antara $\mu_{1}$ dan $\mu_{0}$, sedangkan Ha adalah $\mu_{1}$ lebih besar $\mu_{0}$.

3. Ho : $\mu_{1}=\mu_{0}$ vs Ha : $\mu_{1}<\mu_{0}$ untuk uji satu sisi/pihak/ekor sebelah kiri negatif. Pernyataan untuk Ho adalah tidak ada perbedaan antara $\mu_{1}$ dan $\mu_{0}$, sedangkan Ha adalah $\mu_{1}$ lebih kecil $\mu_{0}$. 


\section{B. Nilai Signifikansi $(\alpha)$}

Nilai $\alpha$ biasanya disebut derajat kemaknaan atau level signifikansi suatu penelitian. Secara mudah sebenarnya nilai $\alpha$ identik dengan tingkat kesalahan suatu penelitian. Suatu penelitian dengan menggunakan $\alpha=5 \%$ berarti tingkat kesalahan penelitian tersebut $5 \%$, dengan kalimat dapat disebutkan bahwa diantara 100 kejadian sebanyak 5 kejadian yang menyimpang.

\begin{tabular}{|c|c|c|}
\hline \multirow{2}{*}{ KESIMPULAN } & \multicolumn{2}{|c|}{ KEADAAN SEBENARNYA } \\
\cline { 2 - 3 } & HIPOTESIS BENAR & HIPOTESIS SALAH \\
\hline MENERIMA HIPOTESIS & BENAR & $\begin{array}{c}\text { KEKELIRUAN TIPE II } \\
(\beta)\end{array}$ \\
\hline MENOLAK HIPOTESIS & $\begin{array}{c}\text { KEKELIRUAN TIPE I } \\
(\alpha)\end{array}$ & BENAR \\
\hline
\end{tabular}

Nilai $\alpha$ adalah sama dengan proporsi luasan daerah penolakan terhadap keseluruhan luasan kurva. Berdasarkan tabel di atas $\alpha$ diartikan sebagai kekeliruan untuk menolak hipotesis ternyata hipotesis tersebut benar.

Besarnya nilai $\alpha$ ditentukan oleh peneliti sendiri. Lazimnya untuk penelitian sosial antara 0,10 s/d 0,05 atau lebih besar dari itu, sedangkan untuk penelitian laboratorium diusahakan sekecil mungkin, misalnya 0,01 atau 0,001 . Penelitian obat-obatnya yang nantinya diterapkan pada manusia nilai sangat kecil misalnya 0,000001, yang berarti diantara 1.000 .000 kejadian hanya satu yang menyimpang.

Pada uji dua sisi, maka secara otomatis nilai $\alpha$ akan dibagi dua, untuk nilai kritis daerah sebelah kanan (positif) dan nilai kritis sebelah kiri (negatif). Uji satu sisi nilai $\alpha$ tetap utuh, karena daerah penolakannya hanya pada sebelah kanan atau sebelah kiri. Pada saat uji dua sisi, sisi sebelah kiri secara otomatis nilai tabel menjadi negatif, demikian juga uji satu sisi sebelah kiri.

Khusus untuk uji statistik non parametrik dan anava selalu menggunakan uji dua sisi, namun nilai $\alpha$ tidak perlu dibagi dua. Pada waktu melihat tabel dan penentuan daerah penolakan digunakan satu sisi sebelah kanan, karena tidak dikenal angka negatif.

C. Rumus Statistik

Rumus statistik sangat tergantung pada keperluannya. Jenis rumus statistik yang kita pelajari dikelompokkan menjadi :

1. Uji beda

a. Uji beda mean

1). Uji beda mean kenyataan vs standar

a). Uji beda mean kenyataan vs standar (standar deviasi/ $\sigma$ diketahui dari populasi standar) (uji Z score distribusi standar)

b). Uji beda mean kenyataan vs standar (standar deviasi/SD diketahui dari populasi kenyataan) (uji t test, distribusi student)

2). Uji beda mean kenyataan vs kenyataan

a). Uji beda mean kenyataan vs kenyataan, satu sampel, data berpasangan (pre post) (uji t test)

b). Uji beda mean kenyataan vs kenyataan, dua sampel/populasi, (uji t test) 
c). Uji beda mean kenyataan vs kenyataan, dua atau lebih sampel/populasi (uji anava)

b. Uji beda proporsi (uji Z)

c. Uji beda data kategorik (statistik non parametrik / $\mathrm{X}^{2}$ )

2. Uji hubungan
a. Uji Regresi ( R )
b. Uji Korelasi Moment Product Pearson( $r$ )
c. Uji Korelasi Tata Jenjang Spearman ( rho )
d. Uji Asosiasi (statistik non parametrik) ( C )

D. Nilai Statistik

Nilai statistik merupakan hasil perhitungan dari rumus statistik. Hasil hitung uji statistik kadang-kadang mendapat angka negatif. Kondisi ini tidak manjadi masalah, karena ada uji sisi sebelah kiri yang nilainya negatif. Pada uji statistik hubungan, nilai negatif memiliki arti yang tersendiri. Hasil hitungan uji hubungan dapat dilihat langsung kategori eratnya suatu hubungan. Pengelompokan kuat lemah hubungan ada bermacam-macam.

E. Df/Db/Dk (Degree Of Freedom, Derajat Bebas, Derajat Kebebasan)

$\mathrm{Df} / \mathrm{db} / \mathrm{dk}$ (degree of freedom, derajat bebas, derajat kebebasan) merupakan angka bantu untuk mencari nilai pada tabel. Besarnya angka df disesuaikan dengan rumus statistik pengujinya.

F. Nilai Kritis / Nilai Tabel

Dalam menentukan tabel uji, harus sesuai dengan statistik pengujinya.

\begin{tabular}{|c|c|c|c|c|}
\hline No & UJI STATISTIK & TABEL UJI & $\mathrm{DF}$ & KET \\
\hline 1. & $\mathrm{Z}$ test & Z (kurva normal) & - & Uji beda \\
\hline 2. & t test (teori vs kenyataan) & $\mathrm{t}$ & $\mathrm{N}-1$ & Uji beda \\
\hline 3. & $\mathrm{t}$ test data berpasangan (pre-post) & $\mathrm{t}$ & $\mathrm{N}-1$ & Uji beda \\
\hline 4. & $\mathrm{t}$ test (data tidak berpasangan) & $\mathrm{t}$ & $\left(N_{1}-1\right)+\left(N_{2}-1\right)$ & Uji beda \\
\hline 5. & $\mathrm{~F}$ (Anava) & $\mathrm{F}$ & $(\mathrm{K}-1) ;(\mathrm{N}-\mathrm{K})$ & Uji beda \\
\hline 6. & $\mathrm{r}$ & $\begin{array}{l}\text { r Moment Product } \\
\text { Pearson }\end{array}$ & $\mathrm{N}-1$ & Uji korelasi \\
\hline 7. & rho & $\begin{array}{l}\text { rho tata jenjang } \\
\text { Spearman }\end{array}$ & $\mathrm{N}-1$ & Uji korelasi \\
\hline 8. & $\mathrm{X}^{2}$ (Chi-square) & $\mathrm{X}^{2}$ (Chi-square) & $(\mathrm{r}-1)(\mathrm{c}-1)$ & Uji beda \\
\hline
\end{tabular}

Cara menentukan nilai kritis tabel adalah dengan bantuan nilai $\alpha$ dan nilai df. Pada tabel statistik biasanya nilai $\alpha$ selalu berada pada box head atau baris yang paling atas, sedangkan posisi df pada stub atau kolom sebelah kiri atau sebelah kanan. Berdasarkan nilai $\alpha$ pada kolom tertentu (dari atas ke bawah) dan nilai df pada baris tertentu (dari samping kiri ke kanan) terjadi perpotongan pada satu angka, angka itulah sebagai nilai kritis tabel, sebagai batas daerah penolakan. Adakalanya tabel statistik untuk uji satu sisi, ada juga untuk dua sisi. Bila tabel hanya untuk uji satu sisi, maka ketika menggunakan untuk dua sisi nilai $\alpha$ dikalikan dua. Nilai $\alpha=5 \%$ untuk uji satu sisi sama dengan nilai $\alpha$ $=10 \%$ untuk uji dua sisi. 
Khusus tabel Z, nilai $\alpha$ berada pada body tabel, sehingga penentuan nilai tabel langsung dilihat pada tabel. Adakalanya pada tabel $\mathrm{Z}$ nilai $\alpha$ berada di bodi tabel, nilai tabel terletak pada posisi sebelah kiri atau sebelah kanan digabung dengan pada baris yang paling atas. Misal nilai $\alpha=5 \%$, maka kita cari pada body tabel angka 0,05 atau 0,45 atau 0,95 atau yang paling mendekati. Kemudian dilihat secara horizontal, maka angka pada kolom paling kiri itulah sebagai nilai tabel $\mathrm{Z}$ digabungkan dengan nilai $\alpha$ dilihat secara vertikal, maka angka yang berada paling atas itulah sebagai tambahan nilai tabel. Angka 0,05 dalam tabel kurve normal identik dengan 0,95 , karena luasan kurve normal dianggap $100 \%$, sehingga titik $5 \%$ sama dengan titik 95\%. Demikian juga titik 5\% dengan titik $45 \%$, karena sebagian tabel kurve normal hanya dihitung separuhnya atau 50\%. Jadi titik 5\% identik dengan titik $45 \%$ atau $95 \%$.

Demikian juga untuk melihat tabel $\mathrm{F}$, pada umum tabel hanya memuat dua nilai $\alpha$, yaitu $1 \%$ dan 5\%. Pada body tabel $\mathrm{F}$ umumnya terdapat dua angka yang tersusun. Angka yang berada di bawah adalah untuk nilai $\alpha=1 \%$, sedangkan angka yang di atas untuk nilai $\alpha=5 \%$. Df untuk tabel $\mathrm{F}$ berada di kolom paling kiri $\mathrm{df}_{\mathrm{d}}=(\mathrm{N}-\mathrm{K})$ dan baris paling atas untuk $\mathrm{df}_{\mathrm{K}}=(\mathrm{K}-1)$.

G. Daerah Penolakan

Seperti yang telah dijelaskan di atas bahwa pengujian statistik ini hanya untuk menentukan Ho diterima atau ditolak. Daerah penolakan ditentukan dengan menggunakan gambar atau rumus sederhana. Dengan menggunakan gambar, untuk uji dua sisi, maka daerah penolakan terdapat pada sisi sebelah kanan dan sebelah kiri, sedangkan pada bagian tengah merupakan daerah penerimaan. Sedangkan uji satu sisi, maka daerah penolakannya terletak pada sebelah kanan atau sebelah kiri yang dibatasi nilai kritis tabel uji berdasarkan nilai $\alpha$ dan df. Khusus statistik non parametrik $\left(\mathrm{X}^{2}\right)$ dan uji anova $(\mathrm{F})$ daerah penolakan selalu pada posisi sebelah kanan. Angka nilai tabel merupakan batas-batas daerah penolakan. Sisi sebelah kiri secara otomatis nilai selalu negatif walaupun pada nilai tabel tidak ada nilai negatif.

Dengan menggunakan gambar, langkah pertama dibuat gambar kurva normal, kecuali uji statistik non parametrik dan anova dibuat kurva menceng ke kanan. Pada kurva normal posisi ditengah yang membagi kurva simetris merupakan titik angka nol, sedangkan kurva menceng ke kanan posisi nol pada ujung sebelah kiri. Angka hasil melihat tabel diletakkan pada sumbu $\mathrm{X}$, ditandai dengan satu titik. Uji dua sisi berarti ada dua titik sebelah kanan dan kiri, sedangkan uji satu sisi hanya satu titik di sebelah kanan atau di sebelah kiri, uji statistik non parametrik dan anova hanya satu titik di sebelah kanan saja. Berdasarkan titik tersebut dibuat garis tegak lurus sumbu $\mathrm{X}$ hingga memotong kurva. Daerah yang dibentuk antara garis dengan kurve yang menjauhi titik nol disebut sebagai daerah penolakan. Berarti untuk uji dua sisi, mulai dari batas titik nilai tabel sampai ke kanan adalah daerah penolakan dan dari batas titik nilai tabel sampai ke kiri adalah juga daerah penolakan, sedangkan diantara dua titik nilai tabel tersebut termasuk angka nol merupakan daerah penerimaan. Demikian juga untuk uji satu sisi, maka daerah mulai titik nilai tabel sampai ke kanan atau ke kiri (menjauhi angka nol) adalah daerah penolakan, sedangkan daerah penerimaan terletak pada daerah sebaliknya. Langkah selanjutnya adalah angka hasil perhitungan rumus statistik penguji diletakkan pada sumbu X. Titik hasil perhitungan statistik penguji tersebut dilihat, masuk daerah penolakan atau masuk daerah penerimaan. Bila titik tersebut masuk daerah penolakan berarti Ho ditolak dan $\mathrm{Ha}$ diterima, jika sebaliknya masuk daerah penerimaan, berarti Ho diterima dan $\mathrm{Ha}$ ditolak. Perlu diingat bahwa yang diuji adalah Ho, sehingga perhatian utama selalu diarahkan ke Ho, sedangkan Ha sebagai lawan (kebalikan) hanya mengikuti kondisi Ho. 
Uji dua sisi, daerah penolakan pada ujung kanan dan ujung kiri

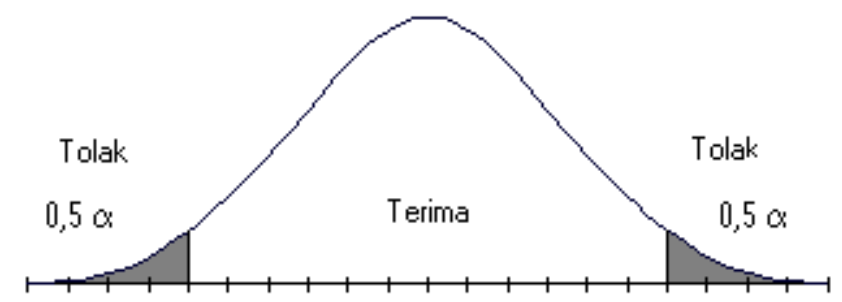

Uji satu sisi, sisi kanan, daerah penolakan pada ujung kanan

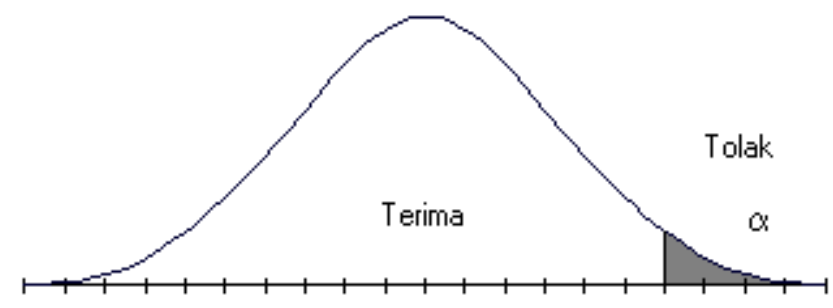

Uji satu sisi, sisi sebelah kiri, daerah penolakan terletak pada ujung kiri

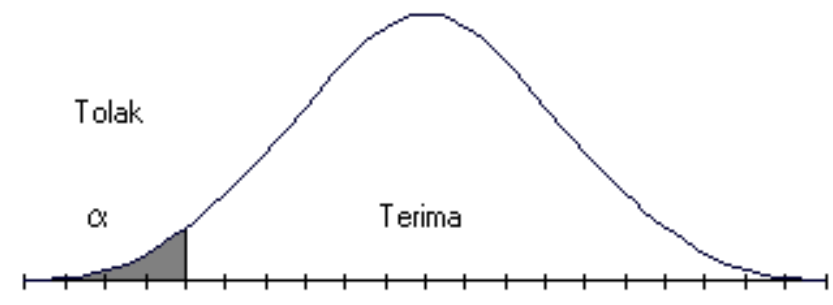

Uji statistik non parametrik dan anova, daerah penolakan sisi sebelah kanan

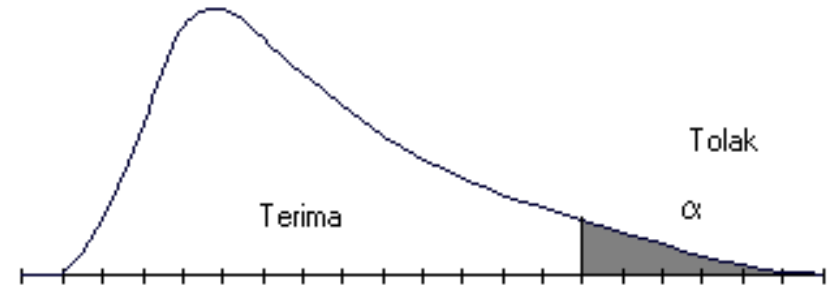

Secara pernyataan matematis dapat dirumuskan sebagai berikut :

1. Nilai mutlak hasil hitung uji statistik ( $\mid$ hasil langkah ke $4 \mid$ ) $\geq$ nilai tabel (langkah ke 6), Ho ditolak, Ha diterima.

2. Nilai mutlak hasil hitung uji statistik ( $\mid$ hasil langkah ke $4 \mid$ ) < nilai tabel (langkah ke 6), Ho diterima, Ha ditolak.

\section{H. Simpulan}

Simpulan merupakan pembacaan hasil langkah ke 7. Pembacaan dilakukan terhadap pernyataan hipotesis yang diterima pada Ho atau Ha dengan diikuti nilai $\alpha$. Bila Ho diterima, maka pada simpulan ditulis pernyataan Ho, demikian sebaliknya. Khusus uji hubungan disertakan nilai koefisien korelasi/asosiasi dan kategori keeratan hubungan. 


\section{BAB VII \\ TERAPAN RUMUS UJI STATISTIK \\ (UJI BEDA)}

A. $\mathrm{Z}$ test untuk menguji beda mean

1. Rumus $Z$

$$
Z=\frac{\bar{X}-\mu_{o}}{\frac{\sigma}{\sqrt{N}}}
$$

Keterangan :

$Z=$ nilai $Z$

$\bar{X}=$ rata-rata data kenyataan

$\mu_{o} \quad=$ rata-rata data standar

$\sigma=$ standar deviasi data standar

$N \quad=$ banyaknya sampel

2. Kegunaan

a.Menguji perbedaan mean data hasil kenyataan di lapangan dengan standar / ketentuan baku / peraturan.

b.Menguji perbedaan mean data hasil kenyataan di lapangan dengan mean data hasil kenyataan di lapangan yang dianggap sebagai standar / ketentuan baku / peraturan.

3. Persyaratan

a.Data berskala interval atau rasio.

b.Standar deviasi (penyimpangan) pada standar (data yang dianggap standar) telah diketahui.

4. Penerapan

Suatu sirup A mempunyai daya tahan 800 hari sampai batas kadaluarsanya, dengan simpangan baku 20 sesuai dengan ketentuan pabrik pembuatnya. Akhir-akhir ini ada keluhan masyarakat, bahwa sirup A sudah rusak sebelum tanggal kadaluarsanya sesuai yang tertulis pada label sirup. Untuk itu dilakukan penelitian terhadap 6 sirup A tersebut. Ternyata didapatkan hasil rata-rata daya tahan sirup A 790 hari. Selidikilah dengan $\alpha=$ $5 \%$, apakah daya tahan sirup A sudah turun?

Penyelesaian :

a. Hipotesis

Ho : $\mathrm{DT}_{790}=\mathrm{DT}_{800}$; daya tahan sirup A tidak beda dengan 800 hari

Ha : $\mathrm{DT}_{790}<\mathrm{DT}_{800}$; daya tahan sirup A kurang dari 800 hari

b. Nilai $\alpha$

$\alpha=5 \%$ 
c. Rumus statistik penguji

$$
Z=\frac{\bar{X}-\mu_{o}}{\frac{\sigma}{\sqrt{N}}}
$$

d. Hitung rumus statistik penguji

Diketahui :

$$
\begin{aligned}
& \bar{X}=790 \\
& \mu_{o}=800 \\
& \sigma \quad=20 \\
& N=6 \\
& Z=\frac{\bar{X}-\mu_{o}}{\frac{\sigma}{\sqrt{N}}} \\
& Z=\frac{790-800}{\frac{20}{\sqrt{6}}} \\
& Z=-1,225
\end{aligned}
$$

e. $\mathrm{Df} / \mathrm{db} / \mathrm{dk}$

Dalam uji $Z$ tidak diperlukan nilai df $(\varnothing)$

f. Nilai tabel

Nilai tabel pada tabel kurva normal (tabel $Z$ )

Uji satu sisi, $\alpha(5 \%)=\mathrm{Z}(1,65)$

g. Daerah penolakan

1). Menggunakan gambar

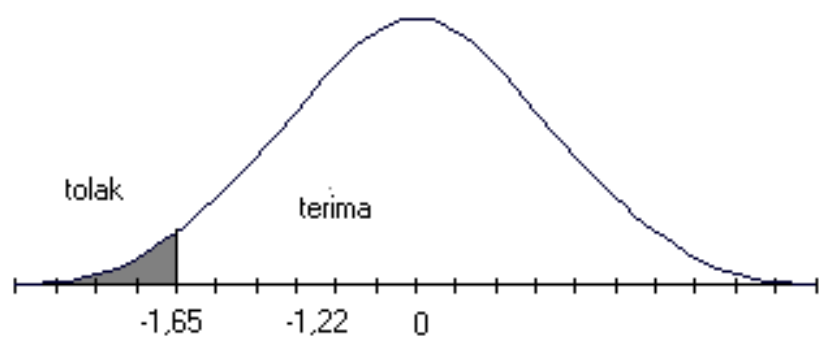

2). Menggunakan rumus

$$
|-1,225|<1,65 \text {; berarti Ho diterima, Ha ditolak }
$$

h. Kesimpulan

Daya tahan sirup A masih sesuai dengan 800 hari pada $\alpha=5 \%$. 
B. $t$ test untuk menguji beda mean

1. Rumus t

$t=\frac{\bar{X}-\mu_{o}}{\frac{S D}{\sqrt{N}}}$

Keterangan :

$t \quad=$ nilai $\mathrm{t}$

$\bar{X} \quad=$ rata-rata data kenyataan

$\mu_{o} \quad=$ rata-rata data standar

$S D=$ standar deviasi data kenyataan

$N \quad=$ banyaknya sampel

2. Kegunaan

a.Menguji perbedaan mean data hasil kenyataan di lapangan dengan standar / ketentuan baku / peraturan.

b.Menguji perbedaan mean data hasil kenyataan di lapangan dengan mean data hasil kenyataan di lapangan yang dianggap sebagai standar / ketentuan baku / peraturan.

3. Persyaratan

a. Data berskala interval atau rasio.

b.Standar deviasi (penyimpangan) pada standar (data yang dianggap standar) tidak diketahui.

4. Penerapan

Tingkat kekeruhan maksimal air minum yang diperbolehkan Permenkes No. 416/Permenkes/IX/1990 adalah 25 unit. Berdasarkan penelitian di lapangan terhadap jenis air mineral A didapatkan tingkat kekeruhannya 26 unit, dengan standar deviasi 3 unit dari pengujian 40 sampel. Selidikilah dengan $\alpha=1 \%$, apakah air mineral A telah melebihi ketentuan permenkes ?

Penyelesaian :

a. Hipotesis

Ho : $\mathrm{K}_{26}=\mathrm{K}_{25}$; kekeruhan air mineral A tidak beda dengan permenkes

$\mathrm{Ha}: \mathrm{K}_{26}>\mathrm{K}_{25}$; kekeruhan air mineral A melebihi permenkes

b. Nilai $\alpha$

$\alpha=1 \%$

c. Rumus statistik penguji

$$
t=\frac{\bar{X}-\mu_{o}}{\frac{S D}{\sqrt{N}}}
$$


d. Hitung rumus statistik penguji

Diketahui :

$$
\begin{aligned}
& \bar{X}=26 \\
& \mu_{o}=25 \\
& S D=3 \\
& N \quad=\quad 40 \\
& t=\frac{\bar{X}-\mu_{o}}{\frac{S D}{\sqrt{N}}} \\
& t=\frac{26-25}{\frac{3}{\sqrt{40}}} \\
& t=2,11
\end{aligned}
$$

e. $\mathrm{Df} / \mathrm{db} / \mathrm{dk}$

$$
\mathrm{Df}=\mathrm{N}-1=40-1=39
$$

f. Nilai tabel

Nilai tabel pada tabel $\mathrm{t}$ distribusi student

Uji satu sisi, $\alpha=1 \%$, df $=39$, nilai t tabel $=2,42$

g. Daerah penolakan

1). Menggunakan gambar

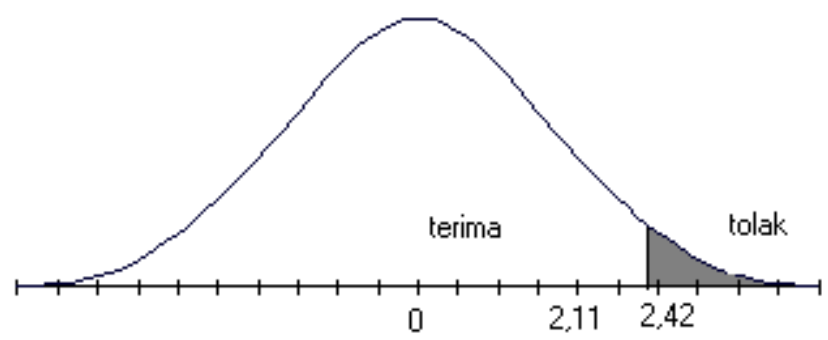

2). Menggunakan rumus

$$
|2,11|<2,42 \text {; berarti Ho diterima, Ha ditolak }
$$

h. Kesimpulan

Tingkat kekeruhan air mineral A tidak beda dengan ketentuan permenkes atau tingkat kekeruhan air mineral A belum melebihi ketentuan permenkes.

C. $t$ test (pre - post) Uji beda dua mean data berpasangan

1. Rumus $\mathrm{t}$

$$
t=\frac{\sum d_{i}}{\sqrt{\frac{N \sum d_{i}^{2}-\left(\sum d_{i}\right)^{2}}{N-1}}}
$$

Keterangan :

$t=$ Nilai $\mathrm{t}$

$D=$ Selisih nilai post dan pre (nilai post - nilai pre)

$N=$ Banyaknya sampel pengukuran 
2. Kegunaan

a.Menguji perbedaan kondisi awal dan setelah perlakukan

b.Melihat efektivitas perubahan

3. Persyaratan

a.Data berpasangan (satu sampel diukur dua kali, yaitu keadaan awal sebelum perlakukan dan setelah perlakuan)

b.Data berdistribusi normal

c. Data berskala interval atau rasio

4. Penerapan

Suatu uji coba model penyuluhan untuk meningkatkan pengetahuan masyarakat telah dilaksanakan didapat data sebagai berikut :

\begin{tabular}{|c|c|c|}
\hline NOMOR & $\begin{array}{c}\text { PENGETAHUAN SEBELUM } \\
\text { PENYULUHAN (PRE) }\end{array}$ & $\begin{array}{c}\text { PENGETAHUAN SETELAH } \\
\text { PENYULUHAN (POST) }\end{array}$ \\
\hline 1. & 30 & 34 \\
\hline 2. & 29 & 29 \\
\hline 3. & 26 & 29 \\
\hline 4. & 29 & 32 \\
\hline 5. & 28 & 28 \\
\hline 6. & 32 & 32 \\
\hline 7. & 30 & 33 \\
\hline 8. & 28 & 28 \\
\hline 9. & 28 & 29 \\
\hline 10. & 26 & 30 \\
\hline 11. & 29 & 30 \\
\hline 12. & 27 & 27 \\
\hline
\end{tabular}

Selidikilah dengan $\alpha=1 \%$, apakah model penyuluhan mampu meningkatkan pengetahuan masyarakat?

Penyelesaian :

a. Hipotesis

Ho : $\mathrm{P}_{\text {post }}=\mathrm{P}_{\text {pre }}$; tidak ada perbedaan pengetahuan antara sebelum dan setelah disuluh $\mathrm{Ha}: \mathrm{P}_{\text {post }}>\mathrm{P}_{\text {pre }}$; ada peningkatan pengetahuan setelah disuluh dibanding sebelumnya

b. Nilai $\alpha$

$\alpha=1 \%$

c. Rumus statistik penguji

$$
t=\frac{\sum d_{i}}{\sqrt{\frac{N \sum d_{i}^{2}-\left(\sum d_{i}\right)^{2}}{N-1}}}
$$


d. Hitung rumus statistik penguji

\begin{tabular}{|r|c|c|c|c|}
\hline NOMOR & $($ PRE) & (POST) & d (post-pre) & $\mathrm{d}^{2}$ \\
\hline 1. & 30 & 34 & 4 & 16 \\
\hline 2. & 29 & 29 & 0 & 0 \\
\hline 3. & 26 & 29 & 3 & 9 \\
\hline 4. & 29 & 32 & 3 & 9 \\
\hline 5. & 28 & 28 & 0 & 0 \\
\hline 6. & 32 & 32 & 0 & 9 \\
\hline 7. & 30 & 33 & 3 & 0 \\
\hline 8. & 28 & 28 & 0 & 1 \\
\hline 9. & 28 & 29 & 1 & 16 \\
\hline 10. & 26 & 30 & 4 & 0 \\
\hline 11. & 29 & 30 & 1 & 61 \\
\hline 12. & 27 & 27 & 0 & 19 \\
\hline JUMLAH & & & & \\
\hline
\end{tabular}

$$
t=\frac{\sum d_{i}}{\sqrt{\frac{N \sum d_{i}^{2}-\left(\sum d_{i}\right)^{2}}{N-1}}}
$$

$$
t=\frac{19}{\sqrt{\frac{12.61-(19)^{2}}{12-1}}}
$$

$$
t=3,27
$$

e. $\mathrm{Df} / \mathrm{db} / \mathrm{dk}$

$\mathrm{Df}=\mathrm{N}-1=12-1=11$

f. Nilai tabel

Nilai tabel pada tabel $\mathrm{t}$ distribusi student

Uji satu sisi, $\alpha=1 \%$, df $=11$, nilai $\mathrm{t}$ tabel $=2,718$

g. Daerah penolakan

1). Menggunakan gambar

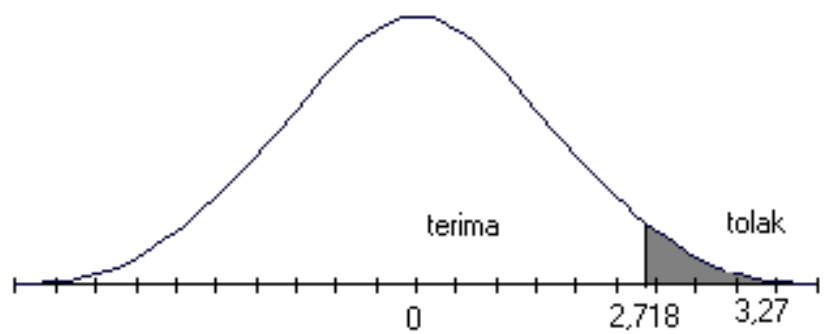

2). Menggunakan rumus

$|3,27|>2,718$; berarti Ho ditolak, Ha diterima

h. Kesimpulan

Ada peningkatan pengetahuan setelah disuluh dibanding sebelumnya, pada $\alpha=1 \%$. 
D. $t$ test (post - post) Uji beda dua mean data tidak berpasangan

1. Rumus $\mathrm{t}$

$$
\begin{aligned}
& t=\frac{\left|\overline{X_{1}}-\overline{X_{2}}\right|}{S_{x_{1}-x_{2}}}=\frac{\left|\overline{X_{1}}-\overline{X_{2}}\right|}{\sqrt{\frac{S^{2}}{N_{1}}}+\frac{S^{2}}{N_{2}}} \\
& S^{2}=\frac{\sum X_{1}^{2}-\frac{\left(\sum X_{1}\right)^{2}}{N_{1}}+\sum X_{2}^{2}-\frac{\left(\sum X_{2}\right)^{2}}{N_{2}}}{N_{1}+N_{2}-2}
\end{aligned}
$$

Keterangan :

$$
\begin{array}{ll}
\frac{t}{X_{1}} & =\text { Nilai } \mathrm{t} \\
\overline{X_{2}} & =\text { Rata-rata data pertama } \\
X_{1} & =\text { Data-rata data kedua } \\
X_{2} & =\text { Data ke dua } \\
S_{X_{1}-X_{2}} & =\text { Standar error } \\
S^{2} & =\text { Estimasi perbedaan kelompok } \\
N_{1} & =\text { Banyaknya sampel pengukuran kelompok pertama } \\
N_{2} & =\text { Banyaknya sampel pengukuran kelompok kedua }
\end{array}
$$

2. Kegunaan
a.Menguji perbedaan mean data hasil kenyataan di lapangan dengan mean data hasil kenyataan di lapangan.

3. Persyaratan
a. Data berskala interval atau rasio.
b.Data berdistribusi normal.
c. Kedua kelompok memiliki varians yang sama
d.Data kelompok I dan kelompok II tidak harus sama banyaknya

4. Penerapan

Pengukuran sumber kebisingan pada dua industri didapatkan data sebagai berikut :

TINGKAT KEBISINGAN PADA SUMBER BISING INDUSTRI SEMEN \& BAJA

\begin{tabular}{|c|c|}
\hline INDUSTRI SEMEN $(\mathrm{dB})$ & INDUSTRI BAJA $(\mathrm{dB})$ \\
\hline 124 & 142 \\
\hline 120 & 101 \\
\hline 98 & 108 \\
\hline 104 & 124 \\
\hline 132 & 135 \\
\hline 108 & 129 \\
\hline 134 & 143 \\
\hline 130 & 127 \\
\hline 128 & 134 \\
\hline 138 & 129 \\
\hline 120 & 120 \\
\hline
\end{tabular}


Selidikilah dengan $\alpha=5 \%$, apakah ada perbedaan tingkat kebisingan antara di industri semen dan baja?

Penyelesaian :

a. Hipotesis

Ho $:$ K.semen $=$ K.baja $\approx$ tidak berbeda kebisingan di industri semen dan baja

Ha : K.semen $\neq$ K.baja $\approx$ berbeda kebisingan di industri semen dan baja

b. Level signifikansi

$\alpha=5 \%=0,05$

c. Rumus statistik penguji

$$
\begin{aligned}
& t=\frac{\left|\overline{X_{1}}-\overline{X_{2}}\right|}{\sqrt{\frac{S^{2}}{N_{1}}+\frac{S^{2}}{N_{2}}}} \\
& S^{2}=\frac{\sum X_{1}^{2}-\frac{\left(\sum X_{1}\right)^{2}}{N_{1}}+\sum X_{2}^{2}-\frac{\left(\sum X_{2}\right)^{2}}{N_{2}}}{N_{1}+N_{2}-2}
\end{aligned}
$$

d. Hitung nilai statistik penguji

\begin{tabular}{|c|c|c|c|c|}
\hline NO & IND SEMEN & $X_{1}^{2}$ & IND BAJA & $X_{2}^{2}$ \\
\hline 1 & 124 & 15.376 & 142 & 20.164 \\
\hline 2 & 120 & 14.400 & 101 & 10.201 \\
\hline 3 & 98 & 9.604 & 108 & 11.664 \\
\hline 4 & 104 & 10.816 & 124 & 15.376 \\
\hline 5 & 132 & 17.424 & 135 & 18.225 \\
\hline 6 & 108 & 11.664 & 129 & 16.641 \\
\hline 7 & 134 & 17.956 & 143 & 20.449 \\
\hline 8 & 130 & 16.900 & 127 & 16.129 \\
\hline 9 & 128 & 16.384 & 134 & 17.956 \\
\hline 10 & 138 & 19.044 & 129 & 16.641 \\
\hline 11 & 120 & 14.400 & 120 & 14.400 \\
\hline JUMLAH & 1.336 & 163.968 & 1.392 & 177.846 \\
\hline RATA-RATA & 121,45 & \multicolumn{3}{l}{} \\
\hline
\end{tabular}

$$
\begin{aligned}
& S^{2}=\frac{\sum X_{1}^{2}-\frac{\left(\sum X_{1}\right)^{2}}{N_{1}}+\sum X_{2}{ }^{2}-\frac{\left(\sum X_{2}\right)^{2}}{N_{2}}}{N_{1}+N_{2}-2} \\
& S^{2}=\frac{163968-\frac{1336^{2}}{11}+177846-\frac{1392^{2}}{11}}{11+11-2} \\
& S^{2}=169,97
\end{aligned}
$$




$$
\begin{aligned}
& t=\frac{\left|\overline{X_{1}}-\overline{X_{2}}\right|}{\sqrt{\frac{S^{2}}{N_{1}}+\frac{S^{2}}{N_{2}}}} \\
& t=\frac{|121,45-126,55|}{\sqrt{\frac{169,97}{11}+\frac{169,97}{11}}} \\
& t=0,92
\end{aligned}
$$

e. $\mathrm{Df} / \mathrm{dk} / \mathrm{db}$

$$
\mathrm{Df}=\mathrm{N}_{1}+\mathrm{N}_{2}-2=11+11-2=20
$$

f. Nilai tabel

Nilai tabel pada tabel $\mathrm{t}$

Uji dua sisi, $\alpha=5 \%, \mathrm{df}=20$, nilai $\mathrm{t}$ tabel $= \pm 2,086$

g. Daerah penolakan

1). Menggunakan gambar

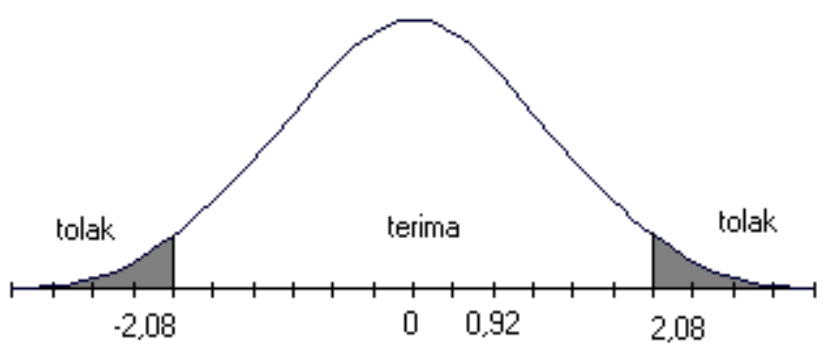

2). Menggunakan rumus

$|0,92|<2,086$; berarti Ho diterima, Ha ditolak

h. Kesimpulan

Tidak berbeda kebisingan di industri semen dan baja, pada $\alpha=5 \%$.

E. Uji U Mann-Whitney beda dua mean

1. Rumus $\mathrm{t}$

$$
\begin{aligned}
& U_{1}=n_{1} \cdot n_{2}+\frac{n_{2}\left(n_{2}+1\right)}{2}-\sum R_{2} \\
& U_{2}=n_{1} \cdot n_{2}+\frac{n_{1}\left(n_{1}+1\right)}{2}-\sum R_{1} \\
& \mathrm{U}_{1}=\mathrm{n}_{1} \cdot \mathrm{n}_{2}-\mathrm{U}_{2} \\
& \mathrm{U}_{2}=\mathrm{n}_{1} \cdot \mathrm{n}_{2}-\mathrm{U}_{1}
\end{aligned}
$$


Keterangan :

$\mathrm{U}_{1} \quad=$ Penguji $\mathrm{U}_{1}$

$\mathrm{U}_{2}=$ Penguji $\mathrm{U}_{2}$

$\mathrm{R}_{1} \quad=$ Jumlah rank sampel 1

$\mathrm{R}_{2}=$ Jumlah rank sampel 2

$\mathrm{n}_{1} \quad=$ Banyaknya anggota sampel 1

$\mathrm{n}_{2}=$ Banyaknya anggota sampel 2

2. Kegunaan

a.Menguji perbedaan dua mean data hasil kenyataan di lapangan dengan mean data hasil kenyataan di lapangan.

3. Persyaratan

a. Data berskala interval atau rasio.

b.Data kelompok I dan kelompok II tidak harus sama banyaknya

4. Penerapan

Pengukuran denyut nadi olahragawan wanita dan pria didapatkan data sebagai berikut

\begin{tabular}{|c|c|c|}
\hline NOMOR & DENYUT NADI PRIA & DENYUT NADI WANITA \\
\hline 1. & 90 & 79 \\
\hline 2. & 89 & 82 \\
\hline 3. & 82 & 85 \\
\hline 4. & 89 & 88 \\
\hline 5. & 91 & 85 \\
\hline 6. & 86 & 80 \\
\hline 7. & 85 & 80 \\
\hline 8. & 86 & \\
\hline 9. & 84 & \\
\hline
\end{tabular}

Selidikilah dengan $\alpha=1 \%$, apakah ada perbedaan denyut nadi olahragawan pria dan wanita ?

Penyelesaian :

a. Hipotesis

Ho $: D_{\text {pria }}=\mathrm{D}_{\text {wanita }} \approx$ tidak berbeda denyut nadi olahragawan pria dan wanita

Ha $: D_{\text {pria }} \neq D_{\text {wanita }} \approx$ ada berbeda denyut nadi olahragawan pria dan wanita

b. Level signifikansi

$\alpha=1 \%=0,01$

c. Rumus statistik penguji

$$
\begin{aligned}
U_{1} & =n_{1} \cdot n_{2}+\frac{n_{2}\left(n_{2}+1\right)}{2}-\sum R_{2} \\
U_{2} & =n_{1} \cdot n_{2}+\frac{n_{1}\left(n_{1}+1\right)}{2}-\sum R_{1} \\
\mathrm{U}_{1} & =\mathrm{n}_{1} \cdot \mathrm{n}_{2}-\mathrm{U}_{2} \\
\mathrm{U}_{2} & =\mathrm{n}_{1} \cdot \mathrm{n}_{2}-\mathrm{U}_{1}
\end{aligned}
$$


d. Hitung nilai statistik penguji

\begin{tabular}{|c|c|c|}
\hline NOMOR & DENYUT NADI PRIA & DENYUT NADI WANITA \\
\hline 1. & 90 & 79 \\
\hline 2. & 89 & 82 \\
\hline 3. & 82 & 85 \\
\hline 4. & 89 & 88 \\
\hline 5. & 91 & 85 \\
\hline 6. & 86 & 80 \\
\hline 7. & 85 & 80 \\
\hline 8. & 86 & \\
\hline 9. & 84 & \\
\hline
\end{tabular}

Data dicampur antara kelompok pria dan wanita, diurutkan kemudian diranking. Dalam merangking angka yang sama harus dirangking yang sama.

\begin{tabular}{|c|c|c|c|}
\hline NOMOR & DENYUT NADI PRIA & RANKING & ASAL \\
\hline 1. & 79 & 1 & wanita \\
\hline 2. & 80 & 2,5 & wanita \\
\hline 3. & 80 & 2,5 & wanita \\
\hline 4. & 82 & 4,5 & pria \\
\hline 5. & 82 & 4,5 & wanita \\
\hline 6. & 84 & 6 & pria \\
\hline 7. & 85 & 8 & pria \\
\hline 8. & 85 & 8 & wanita \\
\hline 9. & 85 & 8 & wanita \\
\hline 10. & 86 & 10,5 & pria \\
\hline 11. & 86 & 10,5 & pria \\
\hline 12. & 88 & 12 & wanita \\
\hline 13. & 89 & 13,5 & pria \\
\hline 14. & 89 & 13,5 & pria \\
\hline 15. & 90 & 15 & pria \\
\hline 16. & 91 & 16 & pria \\
\hline
\end{tabular}

Kelompok dipisahkan menurut Pria dan Wanita

\begin{tabular}{|c|c|c|c|c|}
\hline NOMOR & PRIA & RANKING & WANITA & RANKING \\
\hline 1. & 82 & 4,5 & 79 & 1 \\
\hline 2. & 84 & 6 & 80 & 2,5 \\
\hline 3. & 85 & 8 & 80 & 2,5 \\
\hline 4. & 86 & 10,5 & 82 & 4,5 \\
\hline 5. & 86 & 10,5 & 85 & 8 \\
\hline 6. & 89 & 13,5 & 85 & 8 \\
\hline 7. & 89 & 13,5 & 88 & 12 \\
\hline 8. & 90 & 15 & & \\
\hline 9. & 91 & 16 & & 38,5 \\
\hline JUMLAH & & 97,5 & & \\
\hline
\end{tabular}

$$
U_{1}=n_{1} \cdot n_{2}+\frac{n_{2}\left(n_{2}+1\right)}{2}-\sum R_{2}
$$




$$
\begin{aligned}
& U_{1}=9 \cdot 7+\frac{7 \cdot(7+1)}{2}-38,5 \\
& U_{1}=52,5 \\
& U_{2}=n_{1} \cdot n_{2}+\frac{n_{1}\left(n_{1}+1\right)}{2}-\sum R_{1} \\
& U_{2}=9 \cdot 7+\frac{9 \cdot(9+1)}{2}-97,5 \\
& U_{2}=10,5 \\
& \mathrm{U}_{1}=\mathrm{n}_{1} \cdot \mathrm{n}_{2}-\mathrm{U}_{2} \\
& \mathrm{U}_{1}=9 \cdot 7-10,5 \\
& \mathrm{U}_{1}=52,5 \\
& \mathrm{U}_{2}=\mathrm{n}_{1} \cdot \mathrm{n}_{2}-\mathrm{U}_{1} \\
& \mathrm{U}_{2}=9 \cdot 7-52,5 \\
& \mathrm{U}_{2}=10,5
\end{aligned}
$$

Nilai $U$ yang terkecil sebagai penguji, yaitu $U_{2}=10,5$

e. $\mathrm{Df} / \mathrm{dk} / \mathrm{db}$

Df tidak diperlukan

f. Nilai tabel

Nilai tabel pada tabel $\mathrm{U}$

Uji dua sisi, $\alpha=5 \%, \mathrm{~m}=9$ dan $\mathrm{n}=7$ nilai tabel $\mathrm{U}=7$

g. Daerah penolakan

Menggunakan rumus

$|10,5|>7$; berarti Ho ditolak, Ha diterima

h. Kesimpulan

Ada berbeda denyut nadi olahragawan pria dan wanita, pada $\alpha=1 \%$.

F. Z test untuk menguji beda proporsi

1. Rumus $Z$

$$
Z=\frac{\frac{X}{N}-\pi_{o}}{\sqrt{\frac{\pi_{o}\left(1-\pi_{o}\right)}{N}}}
$$

Keterangan :

$Z=$ nilai $Z$

$X \quad=$ banyaknya kejadian

$\pi_{\mathrm{o}} \quad=$ proporsi anggapan / standar / acuan

$N=$ banyaknya sampel 
2. Kegunaan

a.Menguji perbedaan proporsi pernyataan / pendapat anggapan / standar / ketentuan baku / peraturan dengan data hasil kenyataan di lapangan.

3. Persyaratan

a.Populasi binom.

4. Penerapan

Menurut pendapat pakar bahwa masyarakat yang mengikuti program keluarga berencana baik secara mandiri atau ikut program pemerintah tidak melebihi $85 \%$ dari keseluruhan masyarakat. Pendapat tersebut diuji dengan mengambil sampel 6800 masyarakat yang diidentifikasi keikutsertaannya terhadap program keluarga berencana. Berdasarkan penelitian diperoleh data, bahwa sebanyak 5824 ikut program keluarga berencana dan 976 orang tidak ikut program keluarga berencana. Selidikilah dengan $\alpha=10 \%$, apakah pendapat pakar tersebut di atas benar ?

Penyelesaian :

a. Hipotesis

Ho : $\pi=85 \%$; proporsi peserta keluarga berencana tidak beda dengan $85 \%$

$\mathrm{Ha}: \pi>85 \%$; proporsi peserta keluarga berencana beda dengan $85 \%$

b. Nilai $\alpha$

$\alpha=10 \%$

c. Rumus statistik penguji

$$
Z=\frac{\frac{X}{N}-\pi_{o}}{\sqrt{\frac{\pi_{o}\left(1-\pi_{o}\right)}{N}}}
$$

d. Hitung rumus statistik penguji

Diketahui :

$$
\begin{aligned}
X & =5824 \\
\pi_{\mathrm{o}} & =85 \% \\
N & =6800
\end{aligned}
$$

$Z=\frac{\frac{X}{N}-\pi_{o}}{\sqrt{\frac{\pi_{o}\left(1-\pi_{o}\right)}{N}}}$

$Z=\frac{\frac{5824}{6800}-0,85}{\sqrt{\frac{0,85(1-0,85)}{6800}}}$

$Z=1,5048$ 
e. $\mathrm{Df} / \mathrm{db} / \mathrm{dk}$

Dalam uji $Z$ tidak diperlukan nilai df $(\varnothing)$

f. Nilai tabel

Nilai tabel pada tabel Z kurva normal

Uji satu sisi $\alpha=10 \% \approx Z=1,28$

g. Daerah penolakan

1). Menggunakan gambar

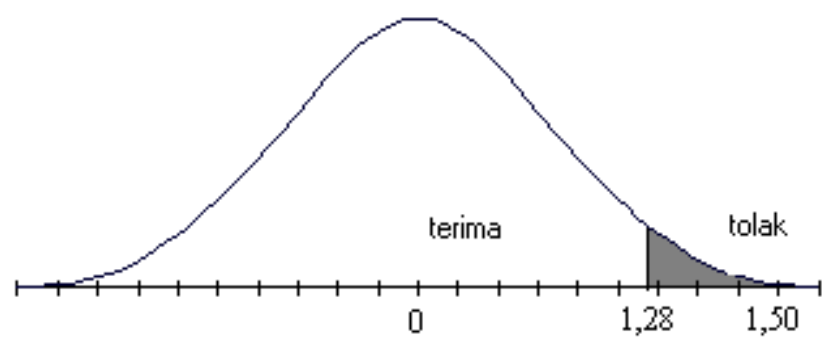

2). Menggunakan rumus

$|1,5048|>1,28$; berarti Ho ditolak, Ha diterima

h. Kesimpulan

Proporsi peserta keluarga berencana beda lebih dari $85 \%$, pada $\alpha=10 \%$.

G. Z test untuk menguji beda dua proporsi

1. Rumus $Z$

$Z=\frac{\frac{X_{1}}{n_{1}}-\frac{X_{2}}{n_{2}}}{\sqrt{p . q .\left(\frac{1}{n_{1}}+\frac{1}{n_{2}}\right)}}$

Keterangan :

$Z=$ nilai $Z$

$X_{1}=$ banyaknya kejadian kelompok 1

$X_{2}=$ banyaknya kejadian kelompok 2

$n_{1} \quad=$ banyaknya sampel 1

$\mathrm{n}_{2}=$ banyaknya sampel 2

$\mathrm{p} \quad=$ proporsi kejadian secara keseluruhan kedua kelompok

$\mathrm{q}=$ proporsi tidak terjadinya kejadian secara keseluruhan kedua kelompok

$p=\frac{X_{1}+X_{2}}{n_{1}+n_{2}}$

$q=1-p$

2. Kegunaan

a.Menguji perbedaan dua proporsi data hasil kenyataan di lapangan. 


\section{Persyaratan}

a.Populasi binom.

4. Penerapan

Bayi yang sudah diimunisasi di Kecamatan Baru sebanyak 467 bayi dari total 542 bayi, sedangkan di Kecamatan Suka sebanyak 571 bayi telah diimunisasi dari total 642 bayi. Selidikilah dengan $\alpha=5 \%$, apakah proporsi bayi yang telah diimunisasi kedua kecamatan tersebut sama?

Penyelesaian :

a. Hipotesis

Ho : $\pi_{\mathrm{S}}=\pi_{\mathrm{B}}$; proporsi pencapaian imunisasi kedua kecamatan tidak beda

$\mathrm{Ha}: \pi_{\mathrm{S}} \neq \pi_{\mathrm{B}}$; proporsi pencapaian imunisasi kedua kecamatan beda

b. Nilai $\alpha$

$\alpha=5 \%$

c. Rumus statistik penguji

$$
\begin{aligned}
& Z=\frac{\frac{X_{1}}{n_{1}}-\frac{X_{2}}{n_{2}}}{\sqrt{p \cdot q \cdot\left(\frac{1}{n_{1}}+\frac{1}{n_{2}}\right)}} \\
& p=\frac{X_{1}+X_{2}}{n_{1}+n_{2}} \\
& \mathrm{q}=1-\mathrm{p}
\end{aligned}
$$

d. Hitung rumus statistik penguji

Diketahui :

$$
\begin{aligned}
& X_{1}=467 \\
& X_{2}=571 \\
& n_{1}=542 \\
& \mathrm{n}_{2}=638 \\
& \mathrm{p}=\frac{X_{1}+X_{2}}{n_{1}+n_{2}}=\frac{467+571}{542+638}=0,8797 \\
& \mathrm{q}=1-\mathrm{p}=1-0,8797=0,1203 \\
& Z=\frac{X_{1}-\frac{X_{2}}{n_{1}}}{\sqrt{p \cdot q \cdot\left(\frac{1}{n_{1}}+\frac{1}{n_{2}}\right)}} \\
& Z=\frac{\sqrt{\frac{467}{542}-\frac{571}{638}}}{\left(0,8797 \cdot 0,1203 \cdot\left(\frac{1}{542}+\frac{1}{638}\right)\right.} \\
& Z=-1,7579
\end{aligned}
$$




\section{e. $\mathrm{Df} / \mathrm{db} / \mathrm{dk}$}

Dalam uji $Z$ tidak diperlukan nilai df $(\varnothing)$

f. Nilai tabel

Nilai tabel pada tabel Z kurva normal

Uji dua sisi $\alpha=5 \% \approx Z= \pm 1,96$

g. Daerah penolakan

1). Menggunakan gambar

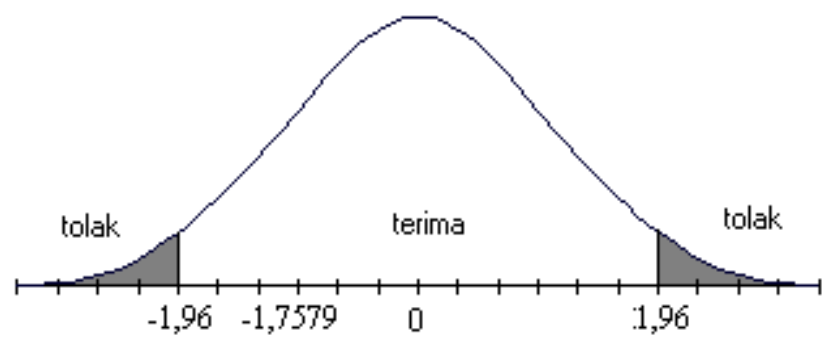

2). Menggunakan rumus

$|-1,7579|<1,96$; berarti Ho diterima, Ha ditolak

h. Kesimpulan

Proporsi pencapaian imunisasi kedua kecamatan tidak beda, pada $\alpha=5 \%$.

H. $\mathrm{X}^{2}$ (Chi-Square)

1. Rumus $X^{2}$

Tabel silang / contingensi ( $\mathrm{r} \times \mathrm{c}$ )

\begin{tabular}{|l|c|c|c|c|}
\hline & Kategorik A & Kategorik B & Kategorik C & Jumlah $(\Sigma i)$ \\
\hline Sampel 1 & $\mathrm{O}_{11}$ & $\mathrm{O}_{12}$ & $\mathrm{O}_{13}$ & $\mathrm{r}_{1}$ \\
\hline Sampel 2 & $\mathrm{O}_{21}$ & $\mathrm{O}_{22}$ & $\mathrm{O}_{23}$ & $\mathrm{r}_{2}$ \\
\hline Sampel 3 & $\mathrm{O}_{31}$ & $\mathrm{O}_{32}$ & $\mathrm{O}_{33}$ & $\mathrm{r}_{3}$ \\
\hline Jumlah $(\Sigma \mathrm{j})$ & $\mathrm{c}_{1}$ & $\mathrm{c}_{2}$ & $\mathrm{c}_{3}$ & $\mathrm{~N}$ \\
\hline
\end{tabular}

Untuk semua jenis tabel contingensi menggunakan rumus :

$$
X^{2}=\sum \sum \frac{\left(O_{i j}-E_{i j}\right)^{2}}{E_{i j}}
$$

khusus tabel contingensi 2 × 2 menggunakan rumus :

$$
\begin{aligned}
& X^{2}=\sum \sum \frac{\left(\left|O_{i j}-E_{i j}\right|-0,5\right)^{2}}{E_{i j}} \\
& E_{i j}=\frac{r_{i} \cdot c_{j}}{N}
\end{aligned}
$$


Keterangan :

$X^{2}=$ Nilai $X^{2}$

$O_{i j} \quad=$ Nilai observasi

$E_{i j} \quad=$ Nilai expected / harapan

$r_{i}=$ Jumlah baris ke $\mathrm{i}$

$c_{j}=$ Jumlah kolom ke $\mathrm{j}$

$N=$ Grand total

2. Kegunaan

a. Menguji perbedaan dua atau lebih kelompok

3. Persyaratan

a.Data berskala katagorik / nominal atau ordinal

b.Data disajikan dalam tabel silang / contingensi

c. Frekuensi kejadian $\left(O_{i j}\right)$ tidak boleh proporsional atau persentase.

d.Nilai expected $\left(E_{i j}\right)$ yang kurang dari 5 tidak boleh lebih dari $20 \%$ dan tidak boleh ada nilai expected $\left(E_{i j}\right)$ kurang dari satu.

e. Tabel 2 x 2 perlu Yate's correction (pengurangan 0,5)

f. Tidak cocok untuk sampel yang kurang dari 20.

g.Setiap sel harus terisi.

4. Penerapan

Suatu uji coba pengobatan TB paru dengan program jangka panjang (12 bulan) dan program jangka pendek (6 bulan) diterapkan pada 60 orang, diperoleh data sebagai berikut :

KESEMBUHAN PENDERITA TB PARU PADA PENGOBATAN PROGRAM 12 BULAN DAN 6 BULAN DI DESA PENAMBANGAN TAHUN 1998

\begin{tabular}{|l|c|c|c|c|}
\hline PRG KSBH & SEMBUH & KARIER & TAK SEMBUH & JUMLAH $(\Sigma \mathrm{i})$ \\
\hline PROG 12 BLN & 16 & 7 & 7 & 30 \\
\hline PROG 6 BLN & 10 & 9 & 11 & 30 \\
\hline JUMLAH $(\Sigma \mathrm{j})$ & 26 & 16 & 18 & 60 \\
\hline
\end{tabular}

Penyelesaian :

a. Hipotesis

Ho : $\mathrm{P}_{12}=\mathrm{P}_{6} \approx$ tidak ada beda kesembuhan TB paru hasil pengobatan program 12 bulan dan program 6 bulan

Ha : $\mathrm{P}_{12} \neq \mathrm{P}_{6} \approx$ ada beda kesembuhan TB paru hasil pengobatan program 12 bulan dan program 6 bulan

b. Nilai $\alpha$

Nilai $\alpha=$ level signifikansi $=10 \%=0,10$

c. Rumus Statistik penguji

$$
X^{2}=\sum \sum \frac{\left(O_{i j}-E_{i j}\right)^{2}}{E_{i j}}
$$


d. Hitung rumus statistik penguji.

\begin{tabular}{|l|c|c|c|c|}
\hline Prog & SEMBUH & KARIER & TAK SEMBUH & JUMLAH $\left(\sum \mathbf{i}\right)$ \\
\hline PROG 12 BLN & 16 & 7 & 7 & 30 \\
\hline PROG 6 BLN & 10 & 9 & 11 & 30 \\
\hline JUMLAH $(\Sigma \mathbf{j})$ & 26 & 16 & 18 & 60 \\
\hline
\end{tabular}

$$
X^{2}=\sum \sum \frac{(O i j-E i j)^{2}}{E i j}
$$

$$
E_{i j}=\frac{r_{i} \cdot c_{j}}{N}
$$

$\begin{array}{llll}\mathrm{O}_{11}=16 & \mathrm{E}_{11}=(30 \times 26) / 60 & =13 \\ \mathrm{O}_{12}=7 & \mathrm{E}_{12}=(30 \times 16) / 60 & =8 \\ \mathrm{O}_{13}=7 & \mathrm{E}_{13}=(30 \times 18) / 60 & =9 \\ \mathrm{O}_{21}=10 & \mathrm{E}_{21}=(30 \times 26) / 60 & =13 \\ \mathrm{O}_{22}=9 & \mathrm{E}_{22}=(30 \times 16) / 60 & =8 \\ \mathrm{O}_{23}=11 & \mathrm{E}_{23}=(30 \times 18) / 60 & =9\end{array}$

$X^{2}=\frac{(16-13)^{2}}{13}+\frac{(7-8)^{2}}{8}+\frac{(7-9)^{2}}{9}+\frac{(10-13)^{2}}{13}+\frac{(9-8)^{2}}{8}+\frac{(11-9)^{2}}{9}$

$X^{2}=2,52$

e. $D f / d b / d k$

$\mathrm{Df}=(\mathrm{r}-1)(\mathrm{c}-1)=(2-1)(3-1)=2$

f. Nilai tabel

Nilai tabel $X^{2}$

$\alpha=0,10 ; \mathrm{df}=2$; Nilai $X^{2}=4,605$

g. Daerah penolakan

1). Menggunakan gambar

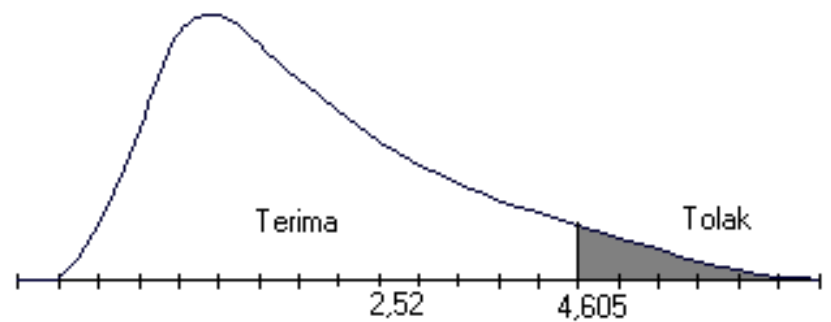

2). Menggunakan rumus

$$
|2,52|<|4,605| \text {; berarti Ho diterima, Ha ditolak }
$$

h. Kesimpulan

Tidak ada beda kesembuhan TB paru hasil pengobatan program 12 bulan dan program 6 bulan pada $\alpha=0,10$. 
Khusus tabel $2 \times 2$

Suatu penelitian daya tahan tubuh laki-laki dan wanita terhadap penyakit Influenza, diperoleh data sebagai berikut :

PENDERITA INFLUENZA MENURUT JENIS KELAMIN

\begin{tabular}{|c|c|c|c|}
\hline JK INF & INFLUENZA (+) & INFLUENZA (-) & JUMLAH \\
\hline Laki-laki & 11 & 6 & 17 \\
\hline Wanita & 9 & 14 & 23 \\
\hline JUMLAH & 20 & 20 & 40 \\
\hline
\end{tabular}

Penyelesaian :

a. Hipotesis

Ho : $\mathrm{L}=\mathrm{W} \approx$ tidak beda daya tahan terhadap influenza antara laki-laki dan wanita

$\mathrm{Ha}: \mathrm{L} \neq \mathrm{W} \approx$ ada beda daya tahan terhadap influenza antara laki-laki dan wanita

b. Nilai $\alpha$

Nilai $\alpha=$ level signifikansi $=5 \%=0,05$

c. Rumus Statistik penguji

$$
X^{2}=\sum \sum \frac{\left(\left|O_{i j}-E_{i j}\right|-0,5\right)^{2}}{E_{i j}}
$$

d. Hitung rumus statistik penguji.

\begin{tabular}{|c|c|c|c|}
\hline JK INF & INFLUENZA (+) & INFLUENZA (-) & JUMLAH \\
\hline Laki-laki & 11 & 6 & 17 \\
\hline Wanita & 9 & 14 & 23 \\
\hline JUMLAH & 20 & 20 & 40 \\
\hline
\end{tabular}

$E_{i j}=\frac{r_{i} \cdot c_{j}}{N}$

$\begin{array}{llll}\mathrm{O}_{11}=11 & \mathrm{E}_{11}=(17 \times 20) / 40=8,5 \\ \mathrm{O}_{12}=6 & \mathrm{E}_{12}=(17 \times 20) / 40=8,5 \\ \mathrm{O}_{21}=9 & \mathrm{E}_{21}=(23 \times 20) / 40=11,5 \\ \mathrm{O}_{22}=14 & \mathrm{E}_{22}=(23 \times 20) / 40=11,5\end{array}$

$X^{2}=\sum \sum \frac{\left(\left|O_{i j}-E_{i j}\right|-0,5\right)^{2}}{E_{i j}}$

$X^{2}=\frac{(|1-8,5|-0,5)^{2}}{8,5}+\frac{(|6-8,5|-0,5)^{2}}{8,5}+\frac{(|9-11,5|-0,5)^{2}}{11,5}+\frac{(|14-11,5|-0,5)^{2}}{11,5}$

$X^{2}=1,64$ 
e. $\mathrm{Df} / \mathrm{db} / \mathrm{dk}$

$\mathrm{Df}=(\mathrm{r}-1)(\mathrm{c}-1)=(2-1)(2-1)=1$

f. Nilai tabel

Nilai tabel $X^{2} ; \alpha=0,05 ; \mathrm{df}=1 ;=3,841$

g. Daerah penolakan

1). Menggunakan gambar

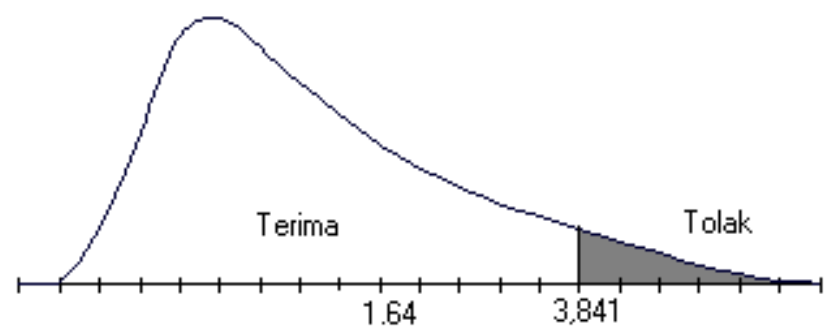

2). Menggunakan rumus

$|1,64|<|3,841|$; berarti Ho diterima, Ha ditolak

h. Kesimpulan

Tidak ada beda daya tahan terhadap influenza antara laki-laki dan wanita, pada $\alpha=$ 0,05 .

I. Analisis Varians (Anava)

1. Rumus F

Ringkasan Anava

\begin{tabular}{|c|c|c|c|c|}
\hline $\begin{array}{c}\text { SUMBER } \\
\text { VARIASI }\end{array}$ & $\begin{array}{c}\text { DERAJAT } \\
\text { KEBEBASAN } \\
(\mathrm{db})\end{array}$ & $\begin{array}{c}\text { JUMLAH KUADRAT } \\
(\mathrm{JK})\end{array}$ & $\begin{array}{c}\text { MEAN } \\
\text { KUADRAT } \\
(\mathrm{MK})\end{array}$ & $\mathrm{F}$ \\
\hline $\begin{array}{c}\text { Kelompok } \\
(\mathrm{K})\end{array}$ & $\mathrm{db}_{\mathrm{K}}=\mathrm{K}-1$ & $J K_{K}=\sum \frac{\left(\sum X_{K}\right)^{2}}{n_{K}}-\frac{\left(\sum X_{T}\right)^{2}}{N}$ & $M K_{K}=\frac{J K_{K}}{d b_{K}}$ & $F=\frac{M K_{K}}{M K_{d}}$ \\
\hline Dalam (d) & $\mathrm{db}_{\mathrm{d}}=\mathrm{N}-\mathrm{K}$ & $\mathrm{JK}_{\mathrm{d}}=\mathrm{JK}_{\mathrm{T}}-\mathrm{JK}_{\mathrm{K}}$ & $M K_{d}=\frac{J K_{d}}{d b_{d}}$ & \\
\hline Total $(\mathrm{T})$ & $\mathrm{db}_{\mathrm{T}}=\mathrm{N}-1$ & $J K_{T}=\sum X_{T}^{2}-\frac{\left(\sum X_{T}\right)^{2}}{N}$ & $\mathrm{MK}_{\mathrm{T}}$ & \\
\hline
\end{tabular}

Keterangan :

$F \quad=$ Nilai $F$

$X=$ Nilai observasi

$n_{K}=$ Banyaknya objek pada kelompok $\mathrm{k}$

$K=$ Banyaknya kelompok

$N=$ Banyaknya seluruh objek 


\section{Kegunaan}

a.Menguji perbedaan mean dari beberapa kelompok (lebih dari dua kelompok) dengan menggunakan analisis variansi.

3. Persyaratan

a.Bila Ho ditolak, maka untuk melihat rincian perbedaan dilanjutkan dengan uji HSD atau LSD atau t test.

4. Penerapan

Di bawah ini data berat badan (satuan $\mathrm{kg}$ ) bayi lahir di empat desa yang dicatat petugas desa masing-masing :

\begin{tabular}{|c|c|c|c|c|}
\hline NOMOR & DESA ARJO & DESA BARU & DESA CITA & DESA DUKU \\
\hline 1. & 2,58 & 3,15 & 2,40 & 2,75 \\
\hline 2. & 2,54 & 2,88 & 2,85 & 2,82 \\
\hline 3. & 2,48 & 2,76 & 3,00 & 2,67 \\
\hline 4. & 2,65 & 3,08 & 3,02 & 2,59 \\
\hline 5. & 2,50 & 3,10 & 2,95 & 2,84 \\
\hline 6. & 2,46 & 2,98 & & 2,74 \\
\hline 7. & & 2,90 & & 2,58 \\
\hline 8. & & 2,89 & & 2,90 \\
\hline 9. & & 3,00 & & \\
\hline
\end{tabular}

Penyelesaian :

\section{a. Hipotesis}

Ho : $\mathrm{B}_{\mathrm{DA}}=\mathrm{B}_{\mathrm{DB}}=\mathrm{B}_{\mathrm{DC}}=\mathrm{B}_{\mathrm{DD}} \approx$ tidak ada perbedaan berat badan bayi baru lahir di Desa Arjo, Desa Baru, Desa Cita, Desa Duku

$\mathrm{Ha}: \mathrm{B}_{\mathrm{DA}} \neq \mathrm{B}_{\mathrm{DB}} \neq \mathrm{B}_{\mathrm{DC}} \neq \mathrm{B}_{\mathrm{DD}} \approx$ ada perbedaan berat badan bayi baru lahir di Desa Arjo, Desa Baru, Desa Cita, Desa Duku

b. Level signifikansi

$\alpha=5 \%$

c. Rumus statistik penguji

\begin{tabular}{|c|c|c|c|c|}
\hline $\begin{array}{c}\text { SUMBER } \\
\text { VARIASI }\end{array}$ & $\begin{array}{c}\text { JUMLAH KUADRAT } \\
(\mathrm{JK})\end{array}$ & $\begin{array}{c}\text { DERAJAT } \\
\text { KEBEBASAN } \\
(\mathrm{db})\end{array}$ & $\begin{array}{c}\text { MEAN } \\
\text { KUADRAT } \\
(\mathrm{MK})\end{array}$ & $\mathrm{F}$ \\
\hline $\begin{array}{c}\text { Kelompok } \\
(\mathrm{K})\end{array}$ & $J K_{K}=\sum \frac{\left(\sum X_{K}\right)^{2}}{n_{K}}-\frac{\left(\sum X_{T}\right)^{2}}{N}$ & $\mathrm{db}_{\mathrm{K}}=\mathrm{K}-1$ & $M K_{K}=\frac{J K_{K}}{d b_{K}}$ & $F=\frac{M K_{K}}{M K_{d}}$ \\
\hline Dalam (d) & $J K_{d}=J K_{T}-J K_{K}$ & $\mathrm{db}_{\mathrm{d}}=\mathrm{N}-\mathrm{K}$ & $M K_{d}=\frac{J K_{d}}{d b_{d}}$ & \\
\hline Total (T) & $J K_{T}=\sum X_{T}^{2}-\frac{\left(\sum X_{T}\right)^{2}}{N}$ & $\mathrm{db}_{\mathrm{T}}=\mathrm{N}-1$ & $\mathrm{MK}_{\mathrm{T}}$ & \\
\hline
\end{tabular}


d. Hitungan rumus statistik penguji

\begin{tabular}{|c|c|c|c|c|c|}
\hline NO & DESA ARJO & DESA BARU & DESA CITA & DESA DUKU & JUMLAH \\
\hline 1. & 2,58 & 3,15 & 2,40 & 2,75 & \\
\hline 2. & 2,54 & 2,88 & 2,85 & 2,82 & \\
\hline 3. & 2,48 & 2,76 & 3,00 & 2,67 & \\
\hline 4. & 2,65 & 3,08 & 3,02 & 2,59 & \\
\hline 5. & 2,50 & 3,10 & 2,95 & 2,84 & \\
\hline 6. & 2,46 & 2,98 & & 2,74 & \\
\hline 7. & & 2,90 & & 2,58 & \\
\hline 8. & & 2,89 & & 2,90 & \\
\hline 9. & & 3,00 & & & \\
\hline$\sum \mathrm{X}_{\mathrm{K}}$ & 15,21 & 26,74 & 14,22 & 21,89 & $78,06 \quad\left(\Sigma \mathrm{X}_{\mathrm{T}}\right)$ \\
\hline $\mathrm{n}_{\mathrm{K}}$ & 6 & 9 & 5 & 8 & $28 \quad(\mathrm{~N})$ \\
\hline Mean & 2,54 & 2,97 & 2,84 & 2,74 & \\
\hline$\Sigma \mathrm{X}_{\mathrm{K}}^{2}$ & 38,58 & 79,57 & 40,71 & 59,99 & $218,85\left(\sum \mathrm{X}_{\mathrm{T}}^{2}\right)$ \\
\hline
\end{tabular}

$$
J K_{T}=\sum X_{T}^{2}-\frac{\left(\sum X_{T}\right)^{2}}{N}
$$

$J K_{T}=218,85-\frac{78,06^{2}}{28}$

$J K_{T}=1,230$

$J K_{K}=\sum \frac{\left(\sum X_{K}\right)^{2}}{n_{K}}-\frac{\left(\sum X_{T}\right)^{2}}{N}$

$J K_{K}=\frac{15,21^{2}}{6}+\frac{26,74^{2}}{9}+\frac{14,22^{2}}{5}+\frac{21,89^{2}}{8}-\frac{78,06^{2}}{28}$

$J K_{K}=0,724$

$J K_{d}=J K_{T}-J K_{K}$

$J K_{d}=1,230-0,724$

$J K_{d}=0,506$

$\mathrm{db}_{\mathrm{K}}=\mathrm{K}-1=4-1=3$

$\mathrm{db}_{\mathrm{d}}=\mathrm{N}-\mathrm{K}=28-4=24$

$\mathrm{db}_{\mathrm{T}}=\mathrm{N}-1=28-1=27$

$M K_{K}=\frac{J K_{K}}{d b_{K}}$ 


$$
\begin{aligned}
& M K_{K}=\frac{0,724}{3} \\
& M K_{K}=0,241 \\
& M K_{d}=\frac{J K_{d}}{d b_{d}} \\
& M K_{d}=\frac{0,506}{24} \\
& M K_{d}=0,021 \\
& F=\frac{M K_{K}}{M K_{d}} \\
& F=\frac{0,241}{0,021} \\
& F=11,476
\end{aligned}
$$

e. $\mathrm{Df} / \mathrm{db} / \mathrm{dk}$

$$
\begin{aligned}
& \mathrm{db}_{\mathrm{K}}=\mathrm{K}-1=4-1=3 \\
& \mathrm{db}_{\mathrm{d}}=\mathrm{N}-\mathrm{K}=28-4=24
\end{aligned}
$$

f. Nilai tabel

Nilai tabel $\mathrm{F}$,

$\alpha=5 \%, \mathrm{df}=3 ; 24$, Nilai tabel $\mathrm{F}=3,01$

g. Daerah penolakan

1). Menggunakan gambar

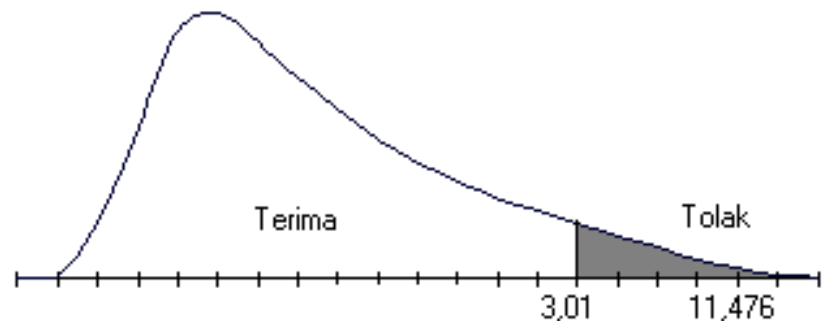

2). Menggunakan rumus

$|11,476|>|3,01|$; berarti Ho ditolak, Ha diterima

h. Simpulan

Ada perbedaan berat badan bayi baru lahir di Desa Arjo, Desa Baru, Desa Cita, Desa Duku, pada $\alpha=5 \%$.

Bila Ho ditolak, maka harus dicari kelompok mana yang berbeda, namun bila Ho diterima, berarti memang keempat kelompok desa tersebut semuanya sama, tidak perlu dicari secara rinci. 
Untuk memerinci perbedaan masing-masing kelompok dapat dilakukan dengan menggunakan :

$\leftrightarrow$ Uji dengan menggunakan Higly Significance Difference (HSD)

$\rightarrow$ Uji dengan menggunakan Leat Significance Difference (LSD)

$\leftrightarrow$ T test untuk dua kelompok sampel yang berbeda (independent)

$\mathrm{HSD}_{0,05}$ antara $\overline{X_{1}}$ dan $\overline{X_{2}}=\mathrm{q}_{0,05, \mathrm{df}=\mathrm{dfd}} \sqrt{\frac{M K_{d}}{N_{1}}+\frac{M K_{d}}{N_{2}}}$

Beda signifikan jika $\left|\overline{X_{1}}-\overline{X_{2}}\right|>\mathrm{HSD}_{0,05}$

$H S D=$ Higly Significance Difference

$\overline{X_{1}}=$ mean kelompok 1

$\overline{X_{2}}=$ mean kelompok 2

$M K_{d}=$ kuadrat dalam

$N_{1} \quad=$ banyaknya anggota sampel 1

$N_{2}=$ banyaknya anggota sampel 2

$q \quad=$ nilai tabel $\mathrm{q}$

\begin{tabular}{|l|c|c|c|}
\hline BEDA & $\mathrm{q}_{0,05, \mathrm{df}=\mathrm{dfd}} \sqrt{\frac{M K_{d}}{N_{1}}+\frac{M K_{d}}{N_{2}}}$ & $\left|\overline{X_{1}}-\overline{X_{2}}\right|$ & KET \\
\hline A vs B & $3,90 \sqrt{\frac{0,021}{6}+\frac{0,021}{9}}=0,297$ & $|2,54-2,97|=0,43$ & signifikan \\
\hline A vs C & $3,90 \sqrt{\frac{0,021}{6}+\frac{0,021}{5}}=0,342$ & $|2,54-2,84|=0,30$ & tidak signifikan \\
\hline A vs D & $3,90 \sqrt{\frac{0,021}{6}+\frac{0,021}{8}}=0,305$ & $|2,54-2,74|=0,20$ & tidak signifikan \\
\hline B vs C & $3,90 \sqrt{\frac{0,021}{9}+\frac{0,021}{5}}=0,314$ & $|2,97-2,84|=0,13$ & tidak signifikan \\
\hline B vs D & $3,90 \sqrt{\frac{0,021}{9}+\frac{0,021}{8}}=0,273$ & $|2,97-2,74|=0,23$ & tidak signifikan \\
\hline C vs D & $3,90 \sqrt{\frac{0,021}{5}+\frac{0,021}{8}}=0,322$ & $|2,84-2,74|=0,10$ & tidak signifikan \\
\hline
\end{tabular}

$\mathrm{LSD}_{0,05}$ antara $\overline{X_{1}}$ dan $\overline{X_{2}}=\mathrm{t}_{0,05, \mathrm{df}=\mathrm{dfd}} \sqrt{\frac{M K_{d}}{N_{1}}+\frac{M K_{d}}{N_{2}}}$

Beda signifikan jika $\left|\overline{X_{1}}-\overline{X_{2}}\right| \geq \operatorname{LSD}_{0,05}$

$$
\begin{aligned}
\frac{L S D}{X_{1}} & =\text { Leat Significance Difference } \\
\frac{X_{2}}{M} & =\text { mean kelompok } 2 \\
M K_{d} & =\text { kuadrat dalam } \\
N_{1} & =\text { banyaknya anggota sampel 1 } \\
N_{2} & =\text { banyaknya anggota sampel 2 } \\
t & =\text { nilai tabel t }
\end{aligned}
$$




\begin{tabular}{|l|c|c|c|}
\hline BEDA & $\mathrm{t}_{0,05 \text { df=dfd } \sqrt{\frac{M K_{d}}{N_{1}}+\frac{M K_{d}}{N_{2}}}}$ & $\left|\overline{X_{1}}-\overline{X_{2}}\right|$ & KET \\
\hline A vs B & $2,064 \sqrt{\frac{0,021}{6}+\frac{0,021}{9}}=0,157$ & $|2,54-2,97|=0,43$ & signifikan \\
\hline A vs C & $2,064 \sqrt{\frac{0,021}{6}+\frac{0,021}{5}}=0,181$ & $|2,54-2,84|=0,30$ & signifikan \\
\hline A vs D & $2,064 \sqrt{\frac{0,021}{6}+\frac{0,021}{8}}=0,161$ & $|2,54-2,74|=0,20$ & signifikan \\
\hline B vs C $2,064 \sqrt{\frac{0,021}{9}+\frac{0,021}{5}}=0,166$ & $|2,97-2,84|=0,13$ & tidak signifikan \\
\hline B vs D & $2,064 \sqrt{\frac{0,021}{9}+\frac{0,021}{8}}=0,144$ & $|2,97-2,74|=0,23$ & signifikan \\
\hline C vs D & $2,064 \sqrt{\frac{0,021}{5}+\frac{0,021}{8}}=0,170$ & $|2,84-2,74|=0,10$ & tidak signifikan \\
\hline
\end{tabular}

J. Uji Normalitas (Uji Goodness of fit Distribusi Normal) Metode Chi Square (n besar)

1. Rumus $X^{2}$

$$
X^{2}=\sum \sum \frac{\left(O_{i}-E_{i}\right)^{2}}{E_{i}}
$$

Keterangan :

$X^{2}=$ Nilai $X^{2}$

$O_{i} \quad=\quad$ Nilai observasi

$E_{i}=$ Nilai expected $/$ harapan $=$ Luasan interval kelas berdasarkan tabel normal dikalikan $\mathrm{N}$

$N=$ Banyaknya angka pada data (total frekuensi)

\begin{tabular}{|c|c|c|c|c|c|}
\hline $\begin{array}{l}\mathrm{N} \\
\mathrm{O}\end{array}$ & $\begin{array}{l}\text { BATAS } \\
\text { INTERVAL } \\
\text { KELAS }\end{array}$ & $\begin{array}{l}\text { Z BATAS } \\
\text { INTERVAL } \\
\text { KELAS } \\
Z=\frac{X_{i}-\bar{X}}{S D}\end{array}$ & $\begin{array}{c}\text { LUAS TIAP INTERVAL } \\
\text { KELAS BERDASAR } \\
\text { TABEL NORMAL } \\
(\text { pi })\end{array}$ & $\begin{array}{c}\text { FREKUENSI } \\
\text { PENGAMATAN } \\
\text { ( Oi) }\end{array}$ & $\begin{array}{l}\text { FREKUENSI } \\
\text { HARAPAN } \\
\text { ( Ei) }\end{array}$ \\
\hline 1. & & & & & \\
\hline 2. & & & & & \\
\hline
\end{tabular}

2. Kegunaan

a.Menguji kenormalan data

3. Persyaratan

a.Data tersusun berkelompok atau dikelompokkan dalam tabel distribusi frekuensi.

b.Data dengan banyaknya angka besar $(n>30)$

c. Setiap sel harus terisi, yang kurang dari 5 digabungkan. 
4. Penerapan

TINGGI BADAN MASYARAKAT KALIMAS TAHUN 1990

\begin{tabular}{|c|c|c|}
\hline NO. & TINGGI BADAN & JUMLAH \\
\hline 1. & $140-149$ & 6 \\
\hline 2. & $150-159$ & 22 \\
\hline 3. & $160-169$ & 39 \\
\hline 4. & $170-179$ & 25 \\
\hline 5. & $180-189$ & 7 \\
\hline 6. & $190-199$ & 1 \\
\hline \multicolumn{2}{|}{} \\
\hline
\end{tabular}

Selidikilah dengan $\alpha=5 \%$, apakah data tersebut di atas berdistribusi normal ?

Penyelesaian :

a. Hipotesis

Ho : Sampel diambil dari populasi normal

Ha : Sampel diambil dari populasi tidak normal

b. Nilai $\alpha$

Nilai $\alpha=$ level signifikansi $=5 \%=0,05$

c. Rumus Statistik penguji

$$
X^{2}=\sum \sum \frac{\left(O_{i}-E_{i}\right)^{2}}{E_{i}}
$$

d. Hitung rumus statistik penguji.

Telah dihitung Mean $=165,3 ;$ Standar deviasi $=10,36$

\begin{tabular}{|c|c|c|c|c|r|}
\hline $\begin{array}{c}\text { N } \\
\text { O. }\end{array}$ & $\begin{array}{c}\text { BNTER } \\
\text { KELAS }\end{array}$ & $\begin{array}{c}\text { Z BATAS } \\
\text { INTERVAL } \\
\text { KELAS } \\
Z=\frac{X_{i}-\bar{X}}{S D}\end{array}$ & $\begin{array}{c}\text { LUAS TIAP INTERVAL } \\
\text { KELAS BERDASAR } \\
\text { TABEL NORMAL } \\
(\mathrm{pi})\end{array}$ & $\begin{array}{c}\text { FREKUENS } \\
\text { I } \\
\text { PENGAMA } \\
\text { TAN ( Oi) }\end{array}$ & $\begin{array}{c}\text { FREKUENSI } \\
\text { HARAPAN } \\
(\mathrm{Ei})\end{array}$ \\
\hline 1. & $139,5-149,5$ & $-2,49--1,53$ & $0,0064-0,0630=0,0566$ & 6 & 5,66 \\
\hline 2. & $149,5-159,5$ & $-1,53--0,56$ & $0,0630-0,2877=0,2247$ & 22 & 22,47 \\
\hline 3. & $159,5-169,5$ & $-0,56-0,41$ & $0,2877-0,6591=0,3714$ & 39 & 37,14 \\
\hline 4. & $169,5-179,5$ & $0,41-1,37$ & $0,6591-0.9147=0,2556$ & 25 & 25,56 \\
\hline 5. & $179,5-189,5$ & $1,37-2,34$ & $0,9147-0,9904=0,0757$ & 7 & 7,57 \\
\hline 6. & $189,5-199,5$ & $2,34-3,30$ & $0,9904-0,9995=0,0091$ & 1 & 0,91 \\
\hline JUMLAH & & & & 100 & \\
\hline
\end{tabular}

Keterangan luasan pi dihitung mulai dari ujung kurva paling kiri sampai ke titik Z, namun dapat juga menggunakan sebagian ujung kiri dan sebagian ujung kanan, sehingga hasil pi sebagai berikut. 


$$
\begin{aligned}
& 0,0055-0,0582=0,0527 \\
& 0,0582-0,2709=0,2127 \\
& 0,2709-0,3409=0,3714 \\
& 0,3409-0,0853=0,2556 \\
& 0,0853-0,0096=0,0756 \text { - } \\
& 0,0096-0,0005=0,0091 \\
& X^{2}=\sum \sum \frac{(O i-E i)^{2}}{E i} \\
& X^{2}=\frac{(6-5,66)^{2}}{5,66}+\frac{(22-22,47)^{2}}{22,47}+\frac{(39-37,14)^{2}}{37,14}+\frac{(25-25,56)^{2}}{25,56}+\frac{(8-8,48)^{2}}{8,48} \\
& X^{2}=0,1628
\end{aligned}
$$

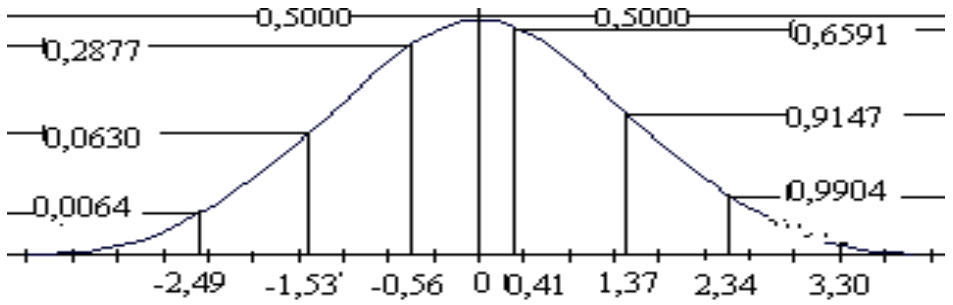

e. $\mathrm{Df} / \mathrm{db} / \mathrm{dk}$

$$
\mathrm{Df}=(\mathrm{k}-3)=(5-3)=2
$$

f. Nilai tabel

Nilai tabel $X^{2} ; \alpha=0,05 ; \mathrm{df}=2 ;=5,991$

g. Daerah penolakan

1). Menggunakan gambar

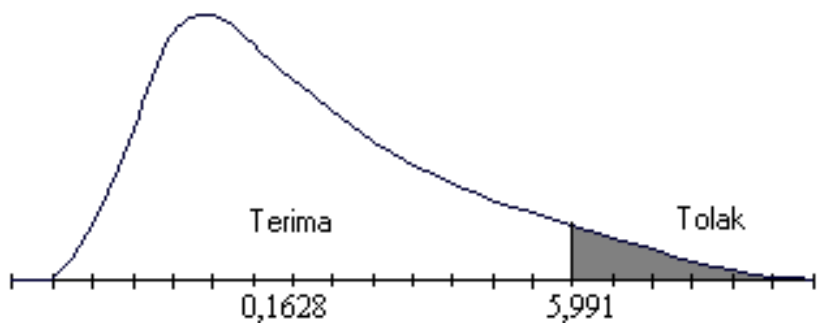

2). Menggunakan rumus

$$
|0,1628|<|5,991| \text {; berarti Ho diterima, Ha ditolak }
$$

h. Kesimpulan

Sampel diambil dari populasi normal, pada $\alpha=0,05$.

K. Uji Normalitas Metode Lilliefors ( $\mathrm{n}$ kecil dan $\mathrm{n}$ besar)

1. Rumus

\begin{tabular}{|c|c|c|c|c|c|}
\hline $\mathrm{NO}$ & $\mathrm{Xi}$ & $Z=\frac{X_{i}-\bar{X}}{S D}$ & $\mathrm{~F}(\mathrm{x})$ & $\mathrm{S}(\mathrm{x})$ & $|\mathrm{F}(\mathrm{x})-\mathrm{S}(\mathrm{x})|$ \\
\hline 1 & & & & & \\
\hline 2 & & & & & \\
\hline 3 & & & & & \\
\hline
\end{tabular}


Keterangan :

$X i=$ Angka pada data

$Z=$ Transformasi dari angka ke notasi pada distribusi normal

$F(x)=$ Probabilitas komulatif normal

$S(x)=$ Probabilitas komulatif empiris

$\mathrm{F}(\mathrm{x})=$ komulatif proporsi luasan kurva normal berdasarkan notasi $\mathrm{Zi}$, dihitung dari luasan kurva mulai dari ujung kiri kurva sampai dengan titik Z.

$S_{(X)}=\frac{\text { banyaknya..angka..sampai..angka..ke..n } n_{i}}{\text { banyaknya..seluruh..angka..pada..data}}$

2. Kegunaan

a. Menguji normalitas suatu data

3. Persyaratan

a. Data berskala interval, ratio (kuantitatif)

4. Penerapan

Diketahui berat badan responden ; 46, 57, 52, 63, 70, 48, 52, 52, 54, 46, 65, 45, 68, 71, $69,61,65,68$. Selidikilah dengan $\alpha=5 \%$, apakah data tersebut di atas berdistribusi normal ?

Penyelesaian :

a. Hipotesis

Ho : Sampel diambil dari populasi normal

Ha : Sampel diambil dari populasi tidak normal

b. Nilai $\alpha$

Nilai $\alpha=$ level signifikansi $=5 \%=0,05$

c. Rumus Statistik penguji

\begin{tabular}{|c|c|c|c|c|c|}
\hline $\mathrm{NO}$ & $\mathrm{Xi}$ & $Z=\frac{X_{i}-\bar{X}}{S D}$ & $\mathrm{~F}(\mathrm{x})$ & $\mathrm{S}(\mathrm{x})$ & $|\mathrm{F}(\mathrm{x})-\mathrm{S}(\mathrm{x})|$ \\
\hline 1 & & & & & \\
\hline 2 & & & & & \\
\hline 3 & & & & & \\
\hline dst & & & & & \\
\hline
\end{tabular}

d. Hitung rumus statistik penguji.

\begin{tabular}{|c|c|c|c|c|c|c|}
\hline NO & $\mathrm{Xi}$ & $Z=\frac{X_{i}-\bar{X}}{S D}$ & $\begin{array}{l}\text { Luasan } \\
\text { kurva } \\
\text { normal }\end{array}$ & $\mathrm{F}(\mathrm{x})$ & $\mathrm{S}(\mathrm{x})$ & $F(x)-S(x)$ \\
\hline 1 & 45 & $-1,4577$ & 0,4279 & 0,0721 & 0,0556 & 0,0165 \\
\hline 2 & 46 & & & & & \\
\hline 3 & 46 & $-1,3492$ & 0,4115 & 0,0885 & 0,1667 & 0,0782 \\
\hline
\end{tabular}




\begin{tabular}{|c|c|c|c|c|c|c|}
4 & 48 & $-1,1323$ & 0,3708 & 0,1292 & 0,2222 & 0,0930 \\
\hline 5 & 52 & & & & & \\
\cline { 1 - 1 } 6 & 52 & & & & & 0,1469 \\
\hline 7 & 52 & $-0,6985$ & 0,2580 & 0,2420 & 0,3889 & 0,1288 \\
\hline 8 & 54 & $-0,4816$ & 0,1844 & 0,3156 & 0,4444 & 0,0636 \\
\hline 9 & 57 & $-0,1562$ & 0,0636 & 0,4364 & 0,5000 & 0,0547 \\
\hline 10 & 61 & 0,2777 & 0,1103 & 0,6103 & 0,5556 & 0,0768 \\
\hline 11 & 63 & 0,4946 & 0,1879 & 0,6879 & 0,6111 & 0,0389 \\
\hline 12 & 65 & & & & & 0,0175 \\
\hline 13 & 65 & 0,7115 & 0,2611 & 0,7611 & 0,7222 & 0,0140 \\
\hline 14 & 68 & & & & & 0,0500 \\
\hline 15 & 68 & 1,0369 & 0,3508 & 0,8508 & 0,8333 & 0,0869 \\
\hline 16 & 69 & 1,1453 & 0,3749 & 0,8749 & 0,8889 & \\
\hline 17 & 70 & 1,2538 & 0,3944 & 0,8944 & 0,9444 & \\
\hline 18 & 71 & 1,3623 & 0,4131 & 0,9131 & 1,0000 & \\
\cline { 1 - 1 } Mean & 58,44 & & & & & \\
\cline { 1 - 1 } SD & 9,22 & & & & &
\end{tabular}

Nilai $|\mathrm{F}(\mathrm{x})-\mathrm{S}(\mathrm{x})|$ tertinggi sebagai angka penguji normalitas, yaitu 0,1469

e. $\mathrm{Df} / \mathrm{db} / \mathrm{dk}$

$\mathrm{Df}=\phi=$ tidak diperlukan

f. Nilai tabel

Nilai Kuantil Penguji Lilliefors

$\alpha=0,05 ; \mathrm{N}=18 ; \approx 0,2000$

g. Daerah penolakan

Menggunakan rumus

$|0,1469|<|0,2000|$; berarti Ho diterima, Ha ditolak

h. Kesimpulan

Sampel diambil dari populasi normal, pada $\alpha=0,05$. 


\section{BAB VIII \\ TERAPAN RUMUS UJI STATISTIK \\ (UJI HUBUNGAN)}

Uji hubungan yang dibahas pada bab ini, hanya hubungan antara dua variabel. Pemilihan jenis rumus untuk menguji hubungan variabel sangat tergantung pada skala data pada masing-masing variabel, distribusi data dan banyaknya sampel. Secara sederhana pemilihan jenis uji hubungan dapat mengikuti tabel sebagai berikut :

\begin{tabular}{|c|c|c|c|c|c|}
\hline $\mathrm{NO}$ & TECHNIQUE & SYMBOL & VARIABLE 1 & VARIABLE 2 & REMARKS \\
\hline 1. & $\begin{array}{l}\text { Product moment } \\
\text { correlation }\end{array}$ & $\mathrm{r}$ & continuous & continuous & $\begin{array}{l}\text { The most stable tehnique, } \\
\text { i.e., smaliest standard error }\end{array}$ \\
\hline 2. & $\begin{array}{l}\text { Rank difference } \\
\text { correlation (rho) }\end{array}$ & $\mathrm{p}$ & ranks & ranks & $\begin{array}{l}\text { Otten used instead of } \\
\text { product moment when } \\
\text { number of cases is under } 30\end{array}$ \\
\hline 3. & Kendall's tau & $\mathrm{r}$ & ranks & ranks & $\begin{array}{l}\text { Preferable to rho for number } \\
\text { under } 10\end{array}$ \\
\hline 4. & $\begin{array}{l}\text { Biserial } \\
\text { correlation }\end{array}$ & $\mathrm{r}_{\mathrm{bis}}$ & $\begin{array}{l}\text { articial } \\
\text { dichotomy }\end{array}$ & continuous & $\begin{array}{l}\text { Sometimes exceeds } 1 \text {-has a } \\
\text { larger standard error than } r- \\
\text { commonly used in item } \\
\text { analysis }\end{array}$ \\
\hline 5 . & $\begin{array}{l}\text { Widespread } \\
\text { biserial } \\
\text { correlation }\end{array}$ & $r_{\text {wbis }}$ & $\begin{array}{l}\text { widespread } \\
\text { artificial } \\
\text { dichotomy }\end{array}$ & continuous & $\begin{array}{l}\text { Used when you are } \\
\text { especially interested in } \\
\text { persons at the extremens on } \\
\text { the dichotomized variable }\end{array}$ \\
\hline 6. & $\begin{array}{l}\text { Point biserial } \\
\text { correlation }\end{array}$ & $\mathrm{r}_{\mathrm{pbis}}$ & $\begin{array}{l}\text { True } \\
\text { dichotomy }\end{array}$ & continuous & $\begin{array}{l}\text { Yield a lower correlation } \\
\text { than } r_{\text {bis }}\end{array}$ \\
\hline 7. & $\begin{array}{l}\text { Tetrachronic } \\
\text { correlation }\end{array}$ & $\mathrm{r}^{\mathrm{t}}$ & $\begin{array}{l}\text { artificial } \\
\text { dichotomy }\end{array}$ & $\begin{array}{l}\text { artificial } \\
\text { dichotomy }\end{array}$ & $\begin{array}{l}\text { Used when both variables } \\
\text { can be split at criticial points }\end{array}$ \\
\hline 8. & Phi coefficient & $\phi$ & $\begin{array}{l}\text { True } \\
\text { dichotomy }\end{array}$ & $\begin{array}{l}\text { True } \\
\text { dichotomy }\end{array}$ & $\begin{array}{l}\text { Used in calculating } \\
\text { interitem correlations }\end{array}$ \\
\hline 9. & $\begin{array}{l}\text { Contingency } \\
\text { coefficient }\end{array}$ & $\mathrm{C}$ & $\begin{array}{l}2 \text { more } \\
\text { categories }\end{array}$ & $\begin{array}{l}2 \text { more } \\
\text { categories }\end{array}$ & $\begin{array}{l}\text { Comparable to r1 under } \\
\text { certain conditions - closely } \\
\text { related to chi-square }\end{array}$ \\
\hline 10 & $\begin{array}{l}\text { Correlation } \\
\text { ratio, etc. }\end{array}$ & $\mathrm{n}$ & continuous & continuous & $\begin{array}{l}\text { Used to detect nonlinier } \\
\text { relationships. }\end{array}$ \\
\hline
\end{tabular}

Sumber : Arikunto, Suharsimi, 1993, Prosedur Penelitian Suatu Pendekatan Praktik edisi revisi II cetakan ke sembilan, Jakarta : PT. Rineka Cipta.

Pengkategorian kuat lemah hubungan antar variabel secara umum dapat mengikuti pengelompokkan sebagai berikut :

\begin{tabular}{|c|c|l|}
\hline NOMOR & BESARNYA NILAI HUBUNGAN & INTERPRETASI HUBUNGAN \\
\hline 1 & $0,80-1,00$ & Tinggi \\
\hline 2 & $0,06-0,80$ & Cukup \\
\hline 3 & $0,40-0,60$ & Agak rendah \\
\hline 4 & $0,20-0,40$ & Rendah \\
\hline 5 & $0,00-0,20$ & Sangat rendah \\
\hline
\end{tabular}


Pengelompok dapat menggunakan interval yang berbeda-beda, misalnya : 0,00-0,10 dalam kategori hubungan lemah, 0,10 - 050 dalam kategori hubungan sedang dan 0,50 - 1,00 dalam kategori hubungan kuat.

Pada harga positif nilai hubungan menunjukkan bahwa semakin besar nilai variabel 1 diikuti semakin besar nilai variabel 2 atau sebaliknya, semakin kecil nilai variabel 1 diikuti semakin kecil nilai variabel 2. Harga negatif yang dihasilkan pada perhitungan menunjukkan bahwa terjadi hubungan secara terbalik, yaitu semakin besar nilai variabel 1 diikuti semakin kecil nilai variabel 2 atau sebaliknya, semakin kecil nilai variabel 1 diikuti semakin besar nilai variabel 2 .

\section{A. Koefisien Contingensi ( C )}

1. Rumus C

Tabel silang / contingensi

\begin{tabular}{|l|c|c|c|c|}
\hline & Kategorik A & Kategorik B & Kategorik C & Jumlah $(\Sigma \mathrm{i})$ \\
\hline Kategorik X & $\mathrm{O}_{11}$ & $\mathrm{O}_{12}$ & $\mathrm{O}_{13}$ & $\mathrm{r}_{1}$ \\
\hline Kategorik Y & $\mathrm{O}_{21}$ & $\mathrm{O}_{22}$ & $\mathrm{O}_{23}$ & $\mathrm{r}_{2}$ \\
\hline Kategorik Z & $\mathrm{O}_{31}$ & $\mathrm{O}_{32}$ & $\mathrm{O}_{33}$ & $\mathrm{r}_{3}$ \\
\hline Jumlah $(\Sigma \mathrm{j})$ & $\mathrm{c}_{1}$ & $\mathrm{c}_{2}$ & $\mathrm{c}_{3}$ & $\mathrm{~N}$ \\
\hline
\end{tabular}

$$
C=\sqrt{\frac{X^{2}}{N+X^{2}}}
$$

Keterangan :

$$
\begin{aligned}
C & =\text { Koefisien Contingensi } \\
X^{2} & =\text { Nilai perhitungan } X^{2} / \text { Chi-Square } \\
N & =\text { Banyaknya sampel }
\end{aligned}
$$

2. Kegunaan

a.Menguji kuat lemah hubungan tabel $2 \times 2$ atau lebih

b.Mengetahui kemaknaan (signifikansi) hubungan tabel $2 \times 2$ atau lebih

3. Persyaratan

c. Data berskala nominal atau ordinal

d.Sangat bagus untuk masing-masing kategori lebih dari dua

4. Penerapan

Suatu hasil penelitian tentang perumahan penduduk didapatkan data sebagai berikut :

HUBUNGAN LUAS LUBANG VENTILASI RUMAH DENGAN ADANYA KASUS ISPA PADA KELUARGA DI DESA REJO TAHUN 1987

\begin{tabular}{|l|c|c|c|c|}
\hline \multirow{2}{*}{$\begin{array}{l}\text { ADANYA KASUS } \\
\text { ISPA }\end{array}$} & \multicolumn{3}{|c|}{ LUAS LUBANG VENTILASI / luas lantai } & \multirow{2}{*}{ JUMLAH } \\
\cline { 2 - 4 } & $<10 \%$ & $10 \%-20 \%$ & $>20 \%$ & \\
\hline ADA KASUS & 16 & 24 & 20 & 60 \\
\hline TIDAK ADA KASUS & 12 & 30 & 22 & 64 \\
\hline JUMLAH & 28 & 54 & 42 & 124 \\
\hline
\end{tabular}




\section{Penyelesaian}

a. Hipotesis

Ho : $\mathrm{C}=0 \approx$ tidak ada hubungan antara ventilasi dengan adanya kasus ISPA

$\mathrm{Ha}: \mathrm{C} \neq 0 \approx$ ada hubungan antara ventilasi dengan adanya kasus ISPA

b. Level signifikansi

$\alpha=10 \%=0,10$

c. Rumus statistik penguji

$$
\begin{aligned}
& C=\sqrt{\frac{X^{2}}{N+X^{2}}} \\
& X^{2}=\sum \sum \frac{(O i j-E i j)^{2}}{E i j} \\
& E_{i j}=\frac{r_{i} \cdot c_{j}}{N}
\end{aligned}
$$

\begin{tabular}{|c|c|c|c|c|}
\hline \multirow{2}{*}{$\begin{array}{l}\text { ADANYA KASUS } \\
\text { ISPA }\end{array}$} & \multicolumn{3}{|c|}{ LUAS LUBANG VENTILASI / luas lantai } & \multirow{2}{*}{ JUMLAH } \\
\hline & $<10 \%$ & $10 \%-20 \%$ & $>20 \%$ & \\
\hline ADA KASUS & 16 & 24 & 20 & 60 \\
\hline TIDAK ADA KASUS & 12 & 30 & 22 & 64 \\
\hline JUMLAH & 28 & 54 & 42 & 124 \\
\hline
\end{tabular}

d. Hitung ststistik penguji

1). Hitungan

$$
\begin{array}{llll}
E_{i j}=\frac{r_{i} \cdot c_{j}}{N} & & & \\
& & & \\
\mathrm{O}_{11}=16 & \mathrm{E}_{11}=(60 \times 28) / 124 & =13,55 \\
\mathrm{O}_{12}=24 & \mathrm{E}_{12}=(60 \times 54) / 124 & =26,13 \\
\mathrm{O}_{13}=20 & \mathrm{E}_{13}=(60 \times 42) / 124 & =20,32 \\
\mathrm{O}_{21}=12 & \mathrm{E}_{21}=(64 \times 28) / 124 & =14,45 \\
\mathrm{O}_{22}=30 & \mathrm{E}_{22}=(64 \times 54) / 124 & =27,87 \\
\mathrm{O}_{23}=22 & \mathrm{E}_{23}=(64 \times 42) / 124 & =21,68
\end{array}
$$

$$
X^{2}=\sum \sum \frac{(O i j-E i j)^{2}}{E i j}
$$$$
X^{2}=\frac{(16-13,55)^{2}}{13,55}+\frac{(24-26,13)^{2}}{26,13}+\frac{(20-20,32)^{2}}{20,32}+\frac{(12-14,45)^{2}}{14,45}
$$$$
+\frac{(30-27,87)^{2}}{27,87}+\frac{(22-21,68)^{2}}{21,68}
$$

$X^{2}=1,21$ 


$$
\begin{aligned}
& C=\sqrt{\frac{X^{2}}{N+X^{2}}} \\
& C=\sqrt{\frac{1,21}{124+1,21}} \\
& C=0,10
\end{aligned}
$$

2). Kategori hubungan lemah

e. $D f / d b / d k$

$$
\mathrm{Df}=(\mathrm{r}-1)(\mathrm{c}-1)=(2-1)(3-1)=2
$$

f. Nilai tabel

Nilai tabel $\mathrm{X}^{2}, \alpha=0,10 ; \mathrm{df}=2,=4,61$

g. Daerah penolakan

1). Menggunakan gambar

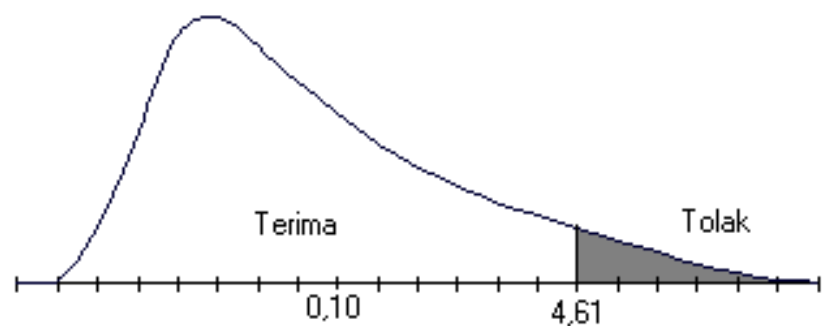

2). Menggunakan rumus

$$
|0,10|<|4,61| \text {; berarti Ho diterima, Ha ditolak }
$$

h. Kesimpulan

Tidak ada hubungan antara ventilasi dengan adanya kasus ISPA, pada $\alpha=10 \%$

B. Koefisien Phi Pearson $(\phi)$

1. Rumus $\phi$

Tabel silang / contingensi

\begin{tabular}{|l|c|c|c|}
\hline & Kategorik A & Kategorik B & Jumlah $(\Sigma \mathrm{i})$ \\
\hline Kategorik X & $\mathrm{O}_{11}$ & $\mathrm{O}_{12}$ & $\mathrm{r}_{1}$ \\
\hline Kategorik Y & $\mathrm{O}_{21}$ & $\mathrm{O}_{22}$ & $\mathrm{r}_{2}$ \\
\hline Jumlah $(\Sigma \mathrm{j})$ & $\mathrm{c}_{1}$ & $\mathrm{c}_{2}$ & $\mathrm{~N}$ \\
\hline
\end{tabular}

$\phi=\sqrt{\frac{X^{2}}{N}}$

Keterangan :

$\phi \quad=$ Koefisien Contingensi

$X^{2}=$ nilai perhitungan $X^{2} /$ Chi-Square

$N \quad=$ banyaknya sampel 
2. Kegunaan

a. Menguji kuat lemah hubungan khusus tabel $2 \times 2$

b. Mengetahui kemaknaan hubungan khusus tabel $2 \times 2$

3. Persyaratan

a. Data berskala nominal atau ordinal

b. Hanya dua kategori

4.Penerapan

HUBUNGAN PENGALAMAN KERJA DENGAN PRODUKTIVITAS KARYAWAN PABRIK SEPATU KIS TAHUN 1987

\begin{tabular}{|l|c|c|c|}
\hline \multirow{2}{*}{ PRODUKTIVITAS } & \multicolumn{2}{|c|}{ PENGALAMAN KERJA } & \multirow{2}{*}{ JUMLAH } \\
\cline { 2 - 3 } & $<5 \mathrm{TH}$ & $\geq 5 \mathrm{TH}$ & \\
\hline$<$ STANDAR & 24 & 10 & 34 \\
\hline$\geq$ STANDAR & 12 & 20 & 32 \\
\hline JUMLAH & 36 & 30 & 66 \\
\hline
\end{tabular}

Penyelesaian

a. Hipotesis

Ho: $\phi=0 \approx$ tidak ada hubungan antara pengalaman kerja dengan produktivitas Ha $: \phi \neq 0 \approx$ ada hubungan antara pengalaman kerja dengan produktivitas

b. Level signifikansi

$\alpha=10 \%=0,10$

c. Rumus statistik penguji

$$
\begin{aligned}
& \phi=\sqrt{\frac{X^{2}}{N}} \\
& X^{2}=\sum \sum \frac{\left(\left|O_{i j}-E_{i j}\right|-0,5\right)^{2}}{E_{i j}} \\
& E_{i j}=\frac{r_{i} \cdot c_{j}}{N}
\end{aligned}
$$

d. Hitung statistik penguji

1). Hitungan

\begin{tabular}{|l|c|c|c|}
\hline \multirow{2}{*}{ PRODUKTIVITAS } & \multicolumn{2}{|c|}{ PENGALAMAN KERJA } & \multirow{2}{*}{ JUMLAH } \\
\cline { 2 - 3 } & $<5 \mathrm{TH}$ & $\geq 5 \mathrm{TH}$ & \\
\hline < STANDAR & 24 & 10 & 34 \\
\hline$\geq$ STANDAR & 12 & 20 & 32 \\
\hline JUMLAH & 36 & 30 & 66 \\
\hline
\end{tabular}

$$
\begin{aligned}
E_{i j}=\frac{r_{i} \cdot c_{j}}{N} & \\
\mathrm{O}_{11}=24 & \mathrm{E}_{11}=(34 \times 36) / 66=18,55 \\
\mathrm{O}_{12}=10 & \mathrm{E}_{12}=(34 \times 30) / 66=15,45
\end{aligned}
$$




$$
\begin{aligned}
& \mathrm{O}_{21}=12 \quad \mathrm{E}_{21}=(32 \times 36) / 66=17,45 \\
& \mathrm{O}_{22}=20 \quad \mathrm{E}_{22}=(32 \times 30) / 66=14,55 \\
& X^{2}=\sum \sum \frac{\left(\left|O_{i j}-E_{i j}\right|-0,5\right)^{2}}{E_{i j}} \\
& X^{2}=\frac{(|24-18,55|-0,5)^{2}}{18,55}+\frac{(|10-15,45|-0,5)^{2}}{15,45}+\frac{(|12-17,45|-0,5)^{2}}{17,45} \\
& +\frac{(|20-14,55|-0,5)^{2}}{14,55} \\
& X^{2}=5,96 \\
& \phi=\sqrt{\frac{X^{2}}{N}} \\
& \phi=\sqrt{\frac{5,96}{66}} \\
& \phi=0,30
\end{aligned}
$$

2). Kategori hubungan sedang

e. $\mathrm{Df} / \mathrm{db} / \mathrm{dk}$

Df $=(r-1)(c-1)=(2-1)(2-1)=1$

f. Nilai tabel

Nilai tabel pada tabel $\mathrm{X}^{2}$ distribusi Chi Square

Nilai tabel $X^{2}, \alpha=0,025 ; \mathrm{df}=1,=5,024$

g. Daerah penolakan

1). Menggunakan gambar

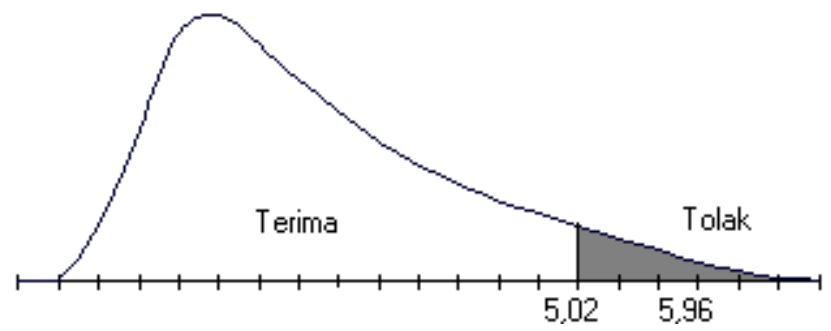

2). Menggunakan rumus

$|5,96|>|5,024|$; berarti Ho ditolak, Ha diterima

h. Kesimpulan

Terdapat hubungan yang bermakna antara pengalaman kerja dengan produktivitas, pada $\alpha=2,5 \%$ 
C. Koefisien Korelasi Tata Jenjang Spearman ( rho )

1. Rumus rho

$$
r h o_{x y}=1-\frac{6 \cdot \sum d^{2}}{N \cdot\left(N^{2}-1\right)}
$$

Keterangan :

$r h o_{x y}=$ Koefisien Korelasi Tata Jenjang Spearman

$d=$ beda ranking variabel pertama dengan variabel kedua

$N=$ banyaknya sampel

2. Kegunaan

a. Menguji signifikansi hubungan dua variabel

b. Mengetahui kuat lemah hubungan

3. Persyaratan

a. Data berskala ordinal, interval atau rasio

4. Penerapan

Berdasar hasil penelitian hubungan tingkat pengetahuan kelompok masyarakat dengan insiden daire didapatkan data sebagai berikut:

\begin{tabular}{|l|l|c|}
\hline \multicolumn{1}{|c|}{ DESA } & \multicolumn{1}{|c|}{$\begin{array}{c}\text { RERATA PENGETAHUAN } \\
\text { MASYARAKAT }\end{array}$} & $\begin{array}{c}\text { INSIDEN } \\
\text { DIARE }(\%)\end{array}$ \\
\hline Aryo & Baik & 8 \\
\hline Koto & Sedang & 13 \\
\hline Mrico & Sangat baik sekali & 5 \\
\hline Sikep & Rendah & 16 \\
\hline Rejo & Baik & 10 \\
\hline Gedang & Sedang & 14 \\
\hline Suka & Rendah & 14 \\
\hline Ganting & Baik & 8 \\
\hline Keboan & Sangat rendah sekali & 23 \\
\hline Kliwon & Sangat baik & 8 \\
\hline Paci & Sangat rendah & 20 \\
\hline Soma & Baik & 9 \\
\hline Alang & Rendah & 14 \\
\hline Kriyo & Sangat rendah & 20 \\
\hline
\end{tabular}

Selidikilah dengan $\alpha=5 \%$, apakah ada hubungan negatif antara tingkat pengetahuan masyarakat dengan insiden diare?

Penyelesaian :

a. Hipotesis

Ho : rho $=0 \approx$ tidak ada hubungan antara pengetahuan dengan insiden diare

$\mathrm{Ha}:$ rho $<0 \approx$ semakin tinggi pengetahuan diikuti dengan semakin rendah insiden diare 
b. Level signifikansi

$\alpha=5 \%=0,05$

c. Rumus statistik penguji

$$
r h o_{X Y}=1-\frac{6 \sum D^{2}}{N\left(N^{2}-1\right)}
$$

d. Hitung rumus statistik penguji

1). Hitungan

\begin{tabular}{|r|l|l|r|r|r|r|r|}
\hline No & DESA & $\begin{array}{c}\text { RERATA } \\
\text { PENGETAHUAN } \\
\text { MASYARAKAT }\end{array}$ & $\begin{array}{c}\text { INSIDEN } \\
\text { DIARE } \\
(\%)\end{array}$ & $\begin{array}{c}\text { RANK } \\
\text { VAR. I }\end{array}$ & $\begin{array}{c}\text { RANK } \\
\text { VAR. II }\end{array}$ & D & D $^{2}$ \\
\hline 1 & Aryo & Baik & 8 & 4,50 & 12,00 & 7,50 & 56,25 \\
\hline 2 & Koto & Sedang & 13 & 7,50 & 8,00 & 0,50 & 0,25 \\
\hline 3 & Mrico & Sangat baik sekali & 5 & 1,00 & 14,00 & 13,00 & 169,00 \\
\hline 4 & Sikep & Rendah & 16 & 10,00 & 4,00 & 6,00 & 36,00 \\
\hline 5 & Rejo & Baik & 10 & 4,50 & 9,00 & 4,50 & 20,25 \\
\hline 6 & Gedang & Sedang & 14 & 7,50 & 6,00 & 1,50 & 2,25 \\
\hline 7 & Suka & Rendah & 8 & 10,00 & 6,00 & 4,00 & 16,00 \\
\hline 8 & Ganting & Baik & 23 & 14,00 & 12,00 & 7,50 & 56,25 \\
\hline 9 & Keboan & Sangat rendah sekali & 8 & 2,00 & 12,00 & 13,00 & 169,00 \\
\hline 10 & Kliwon & Sangat baik & 20 & 12,50 & 2,50 & 10,00 & 100,00 \\
\hline 11 & Paci & Sangat rendah & 9 & 4,50 & 10,00 & 5,50 & 30,25 \\
\hline 12 & Soma & Baik & 14 & 10,00 & 6,00 & 4,00 & 16,00 \\
\hline 13 & Alang & Rendah & 20 & 12,50 & 2,50 & 10,00 & 100,00 \\
\hline 14 & Kriyo & Sangat rendah & & & & & 871,50 \\
\hline & \multicolumn{2}{|l|}{ JUMLAH } & & & &
\end{tabular}

Sangat baik sekali $\quad: 7$

Sangat baik : 6

Baik : 5

Sedang : 4

Rendah : 3

Sangat rendah $: 2$

Sangat rendah sekali : 1

$$
\begin{aligned}
& r h o_{X Y}=1-\frac{6 \sum D^{2}}{N\left(N^{2}-1\right)} \\
& r h o_{X Y}=1-\frac{6.871,50}{14 \cdot\left(14^{2}-1\right)} \\
& r h o_{X Y}=-0,92
\end{aligned}
$$

2). Pengkategorian

Kategori hubungan sangat kuat 
e. $\mathrm{Df} / \mathrm{dk} / \mathrm{db}$

$\mathrm{Df}=\mathrm{N}=14$

f. Nilai tabel

Nilai tabel pada tabel rho

Uji satu sisi, $\alpha=5 \%, \mathrm{df}=14$, nilai rho tabel $=0,456$

g. Daerah penolakan

1). Menggunakan gambar

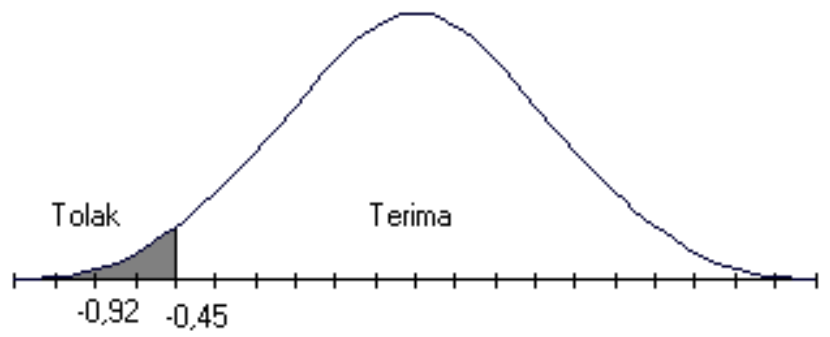

2). Menggunakan rumus

$|-0,92|>|0,456|$; berarti Ho ditolak, Ha diterima

h. Kesimpulan

Semakin tinggi tingkat pengetahuan semakin rendah insiden diare, pada $\alpha=5 \%$.

D. Koefisien Korelasi Moment Product Pearson ( $\mathrm{r}$ )

1. Rumus $r$

$$
r_{x y}=\frac{N \cdot \sum X \cdot Y-\sum X \cdot \sum Y}{\left.\sqrt{\left\{N \cdot \sum X^{2}-\left(\sum X\right)^{2}\right\} N \cdot \sum Y^{2}-\left(\sum Y_{i}\right)^{2}}\right\}}
$$

Keterangan :

$r_{x y}=$ Koefisien Korelasi Moment Product Pearson

$X \quad=$ nilai variabel pertama (variabel bebas)

$Y=$ nilai variabel ke dua (variabel terikat)

$N=$ banyaknya sampel

2. Kegunaan

a. Menguji signifikansi hubungan dua variabel

b. Mengetahui kuat lemah hubungan

3. Persyaratan

a. Data berskala interval atau rasio

b. Data berdistribusi normal

4. Penerapan

Suatu penelitian yang mengkaitkan antara kualitas air (parameter $\mathrm{pH}$ ) dengan jarak sumber air dengan sumber pencemar, didapatkan data sebagai berikut : 


\begin{tabular}{|c|c|c|}
\hline NO & JARAK (X) & $\mathrm{PH}(\mathrm{Y})$ \\
\hline 1 & 4 & 4 \\
\hline 2 & 2 & 2 \\
\hline 3 & 6 & 6 \\
\hline 4 & 7 & 6 \\
\hline 5 & 11 & 7 \\
\hline 6 & 4 & 4 \\
\hline 7 & 13 & 9 \\
\hline 8 & 10 & 8 \\
\hline 9 & 7 & 6 \\
\hline 10 & 5 & 3 \\
\hline 11 & 10 & 7 \\
\hline 12 & 9 & 6 \\
\hline 13 & 8 & 6 \\
\hline 14 & 12 & 7 \\
\hline 15 & 13 & 10 \\
\hline 16 & 10 & 8 \\
\hline 17 & 12 & 7 \\
\hline 18 & 9 & 7 \\
\hline 19 & 8 & 7 \\
\hline 20 & 5 & 5 \\
\hline 21 & 8 & 7 \\
\hline 22 & 9 & 8 \\
\hline 23 & 14 & 11 \\
\hline 24 & 15 & 10 \\
\hline 25 & 14 & 9 \\
\hline 26 & 14 & 9 \\
\hline 27 & 16 & 11 \\
\hline 28 & 10 & 7 \\
\hline 29 & 7 & 6 \\
\hline 30 & 6 & 6 \\
\hline
\end{tabular}

Selidikilah dengan $\alpha=1 \%$, apakah semakin jauh jarak sumber air dengan sumber pencemar diikuti dengan semakin tinggi $\mathrm{pH}$ ?

Penyelesaian :

\section{a. Hipotesis}

Ho $: r=0 \approx$ tidak ada hubungan antara jarak sumber air dengan sumber pencemar dengan kualitas air

Ha $: r>0 \approx$ semakin jauh jarak sumber air dengan sumber pencemar diikuti dengan semakin tinggi $\mathrm{pH}$

b. Level signifikansi

$\alpha=1 \%=0,01$ 
c. Rumus statistik penguji

$$
r_{x y}=\frac{N \cdot \sum X \cdot Y-\sum X \cdot \sum Y}{\left.\sqrt{\left\{N \cdot \sum X^{2}-\left(\sum X\right)^{2}\right)\left(N \cdot \sum Y^{2}-\left(\sum Y_{i}\right)^{2}\right.}\right\}}
$$

d. Hitung rumus statistik penguji

1). Hitungan rumus statistik penguji

\begin{tabular}{|c|c|c|c|c|c|}
\hline NO & JARAK (X) & $\mathrm{PH}(\mathrm{Y})$ & $X^{2}$ & $\mathrm{Y}^{2}$ & $X Y$ \\
\hline 1 & 4 & 4 & 16 & 16 & 16 \\
\hline 2 & 2 & 2 & 4 & 4 & 4 \\
\hline 3 & 6 & 6 & 36 & 36 & 36 \\
\hline 4 & 7 & 6 & 49 & 36 & 42 \\
\hline 5 & 11 & 7 & 121 & 49 & 77 \\
\hline 6 & 4 & 4 & 16 & 16 & 16 \\
\hline 7 & 13 & 9 & 169 & 81 & 117 \\
\hline 8 & 10 & 8 & 100 & 64 & 80 \\
\hline 9 & 7 & 6 & 49 & 36 & 42 \\
\hline 10 & 5 & 3 & 25 & 9 & 15 \\
\hline 11 & 10 & 7 & 100 & 49 & 70 \\
\hline 12 & 9 & 6 & 81 & 36 & 54 \\
\hline 13 & 8 & 6 & 64 & 36 & 48 \\
\hline 14 & 12 & 7 & 144 & 49 & 84 \\
\hline 15 & 13 & 10 & 169 & 100 & 130 \\
\hline 16 & 10 & 8 & 100 & 64 & 80 \\
\hline 17 & 12 & 7 & 144 & 49 & 84 \\
\hline 18 & 9 & 7 & 81 & 49 & 63 \\
\hline 19 & 8 & 7 & 64 & 49 & 56 \\
\hline 20 & 5 & 5 & 25 & 25 & 25 \\
\hline 21 & 8 & 7 & 64 & 49 & 56 \\
\hline 22 & 9 & 8 & 81 & 64 & 72 \\
\hline 23 & 14 & 11 & 196 & 121 & 154 \\
\hline 24 & 15 & 10 & 225 & 100 & 150 \\
\hline 25 & 14 & 9 & 196 & 81 & 126 \\
\hline 26 & 14 & 9 & 196 & 81 & 126 \\
\hline 27 & 16 & 11 & 256 & 121 & 176 \\
\hline 28 & 10 & 7 & 100 & 49 & 70 \\
\hline 29 & 7 & 6 & 49 & 36 & 42 \\
\hline 30 & 6 & 6 & 36 & 36 & 36 \\
\hline JUMLAH & 278 & 209 & 2.956 & 1.591 & 2.147 \\
\hline
\end{tabular}

$$
\begin{aligned}
& r_{x y}=\frac{N \cdot \sum X \cdot Y-\sum X \cdot \sum Y}{\sqrt{\left.\left\{N \cdot \sum X^{2}-\left(\sum X\right)^{2}\right\} N \cdot \sum Y^{2}-\left(\sum Y_{i}\right)^{2}\right\}}} \\
& r_{x y}=\frac{30.2147-278.209}{\sqrt{\left\{30.2956-(278)^{2}\right\}\left\{30.1591-(209)^{2}\right\}}} \\
& r_{x y}=0,929
\end{aligned}
$$


2). Pengkategorian hubungan

Kategori hubungan sangat kuat

e. $\mathrm{Df} / \mathrm{dk} / \mathrm{db}$

$\mathrm{Df}=\mathrm{N}-1=30-1=29$

f. Nilai tabel

Nilai tabel pada tabel $r$ Moment Product Pearson

Uji satu sisi, $\alpha=1 \%$, df $=29$, nilai $r$ tabel $=0,416$

g. Daerah penolakan

1). Menggunakan gambar

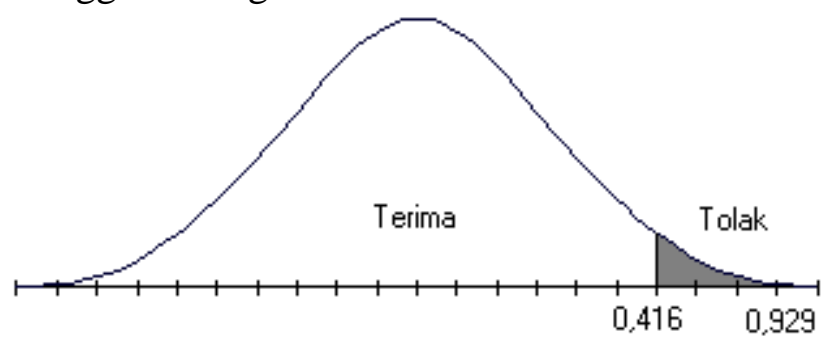

2). Menggunakan rumus

$|0,929|>|0,416|$; berarti Ho ditolak, Ha diterima

h. Kesimpulan

Semakin jauh jarak sumber air dengan sumber pencemar diikuti dengan semakin tinggi $\mathrm{pH}$, pada $\alpha=1 \%$.

Jika data tersebut di atas disajikan dalam bentuk tabel silang sebagai berikut :

\begin{tabular}{|c|c|c|c|c|c|c|}
\hline $\mathrm{pH}$ Jarak & $2-4$ & $5-7$ & $8-10$ & $11-13$ & $14-16$ & JUMLAH \\
\hline $2-3$ & 1 & 1 & & & & 2 \\
\hline $4-5$ & 2 & 1 & & & & 3 \\
\hline $6-7$ & & 5 & 7 & 3 & & 15 \\
\hline $8-9$ & & & 3 & 1 & 2 & 6 \\
\hline $10-11$ & & & & 1 & 3 & 4 \\
\hline JUMLAH & 3 & 7 & 10 & 5 & 5 & 30 \\
\hline
\end{tabular}

Penyelesaian :

a. Hipotesis

Ho $: \mathrm{r}=0 \approx$ tidak ada hubungan antara kualitas air dengan jarak sumber air dengan sumber pencemar.

$\mathrm{Ha}: \mathrm{r}>0 \approx$ ada hubungan antara kualitas air dengan jarak sumber air dengan sumber pencemar.

b. Level signifikansi

$\alpha=1 \%=0,01$

c. Rumus statistik penguji

$$
r_{x y}=\frac{N \cdot \sum f_{i} \cdot X_{i} \cdot Y_{i}-\sum f_{i} \cdot X_{i} \cdot \sum f_{i} \cdot Y_{i}}{\sqrt{\left.\left\{N \cdot \sum f_{i} \cdot X_{i}^{2}-\left(\sum f_{i} \cdot X_{i}\right)^{2}\right\} N \cdot \sum f_{i} \cdot Y_{i}^{2}-\left(\sum f_{i} \cdot Y_{i}\right)^{2}\right\}}}
$$


Keterangan :

$r_{x y}=$ Koefisien Korelasi Moment Product Pearson

$X_{I}=$ titik tengah interval kelas nilai variabel pertama (variabel bebas)

$Y_{I}=$ titik tengah interval kelas nilai variabel ke dua (variabel terikat)

$N=$ banyaknya sampel

$f_{i}=$ frekuensi

d. Hitung rumus statistik penguji

1). Hitungan rumus statistik penguji

\begin{tabular}{|c|c|c|c|c|c|c|c|c|c|c|}
\hline & $2-4$ & $5-7$ & $8-10$ & $11-13$ & $14-16$ & $f_{i}$ & $Y_{i}$ & $f_{i .} Y_{i}$ & $f_{i \cdot} Y_{i}^{2}$ & $f_{i} \cdot Y_{i} \cdot X_{i}$ \\
\hline $2-3$ & 1 & 1 & & & & 2 & 2,5 & 5,0 & 12,50 & 22,5 \\
\hline $4-5$ & 2 & 1 & & & & 3 & 4,5 & 13,5 & 60,75 & 54,0 \\
\hline $6-7$ & & 5 & 7 & 3 & & 15 & 6,5 & 97,5 & 633,75 & 838,5 \\
\hline $8-9$ & & & 3 & 1 & 2 & 6 & 8,5 & 51,0 & 433,50 & 586,5 \\
\hline $10-11$ & & & & 1 & 3 & 4 & 10,5 & 42,0 & 441,00 & 598,5 \\
\hline$f_{i}$ & 3 & 7 & 10 & 5 & 5 & 30 & & 209,0 & 1581,50 & 2100,0 \\
\hline$X_{i}$ & 3 & 6 & 9 & 12 & 15 & & & & & \\
\hline$f_{i} \cdot X_{i}$ & 9 & 42 & 90 & 60 & 75 & 276 & & & & \\
\hline$f_{i} \cdot X_{i}^{2}$ & 27 & 252 & 810 & 720 & 1125 & 2934 & & & & \\
\hline$f_{i} \cdot X_{i} \cdot Y_{i}$ & 34,5 & 237 & 639 & 462 & 727,5 & 2100 & & & & \\
\hline
\end{tabular}

\begin{tabular}{|l|llr|}
\hline$i$ & $f_{i .} Y_{i} X_{i}$ & & \\
\hline 1. & $(1 \times 2,5 \times 3)+(1 \times 2,5 \times 6)$ & $=$ & 22,5 \\
\hline 2. & $(2 \times 4,5 \times 3)+(1 \times 4,5 \times 6)$ & $=$ & 54,0 \\
\hline 3. & $(5 \times 6,5 \times 6)+(7 \times 6,5 \times 9)+(3 \times 6,5 \times 12)$ & $=$ & 838,5 \\
\hline 4. & $(3 \times 8,5 \times 9)+(1 \times 8,5 \times 12)+(2 \times 8,5 \times 15)$ & $=$ & 586,5 \\
\hline 5. & $(1 \times 10,5 \times 12)+(3 \times 10,5 \times 15)$ & $=$ & 598,5 \\
\hline & JUMLAH & $=$ & 2100,0 \\
\hline & & & \\
\hline$i$ & $f_{i .} X_{i} Y_{i}$ & $=$ & 34,5 \\
\hline 1. & $(1 \times 3 \times 2,5)+(2 \times 3 \times 4,5)$ & $=$ & 237,0 \\
\hline 2. & $(1 \times 6 \times 2,5)+(1 \times 6 \times 4,5)+(5 \times 6 \times 6,5)$ & $=$ & 639,0 \\
\hline 3. & $(7 \times 9 \times 6,5)+(3 \times 9 \times 8,5)$ & $=$ & 462,0 \\
\hline 4. & $(3 \times 12 \times 6,5)+(1 \times 12 \times 8,5)+(1 \times 12 \times 10,5)$ & $=$ & 727,5 \\
\hline 5. & $(2 \times 15 \times 8,5)+(3 \times 15 \times 10,5)$ & $=$ & 2100,0 \\
\hline & \multicolumn{1}{|c}{ JUMLAH }
\end{tabular}

Jumlah $f_{i} \cdot Y_{i} \cdot X_{i}$ harus sama dengan jumlah $f_{i} \cdot X_{i} \cdot Y_{i}$

$$
\begin{aligned}
& r_{x y}=\frac{N \cdot \sum f_{i} \cdot X_{i} \cdot Y_{i}-\sum f_{i} \cdot X_{i} \cdot \sum f_{i} \cdot Y_{i}}{\sqrt{\left.\left\{N \cdot \sum f_{i} \cdot X_{i}^{2}-\left(\sum f_{i} \cdot X_{i}\right)^{2}\right\} N \cdot \sum f_{i} \cdot Y_{i}^{2}-\left(\sum f_{i} \cdot Y_{i}\right)^{2}\right\}}} \\
& r_{x y}=\frac{30.2100-276.209}{\sqrt{\left\{30.2934-(276)^{2}\right)\left\{30.1581,5-(209)^{2}\right\}}} \\
& r_{x y}=0,796
\end{aligned}
$$

2). Pengkategorian hubungan

Kategori hubungan sangat kuat 
e. $\mathrm{Df} / \mathrm{dk} / \mathrm{db}$

$\mathrm{Df}=\mathrm{N}-1=30-1=29$

f. Nilai tabel

Nilai tabel pada tabel $r$ Moment Product Pearson

Uji satu sisi, $\alpha=1 \%$, df $=29$, nilai $r$ tabel $=0,416$

g. Daerah penolakan

1). Menggunakan gambar

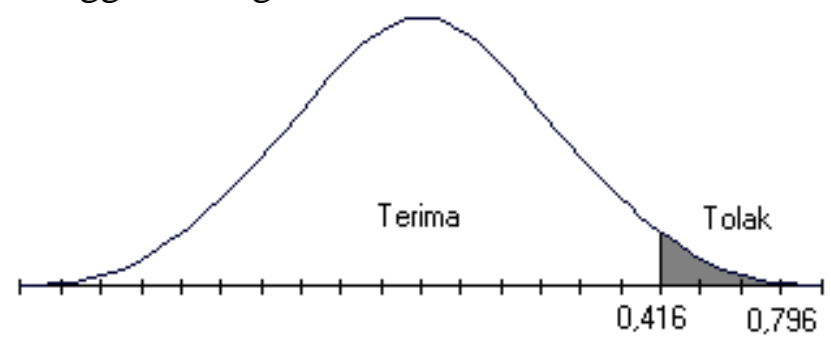

2). Menggunakan rumus

$|0,796|>|0,416|$; berarti Ho ditolak, Ha diterima

h. Kesimpulan

Semakin jauh jarak sumber air dengan sumber pencemar diikuti dengan semakin tinggi $\mathrm{pH}$, pada $\alpha=1 \%$.

E. Regresi

1. Rumus

$Y=a+b X$

Keterangan :

$Y \quad=\quad$ nilai prediksi $\mathrm{y}$ untuk suatu nilai $\mathrm{x}$ tertentu

$X=$ nilai $X$ yang dicoba

$a=$ nilai intercept

$b=$ slope $\Delta \mathrm{Y} / \Delta \mathrm{X}$ (koefisien arah regresi)

$a=\bar{Y}-b \bar{X}=\frac{\sum X^{2} \cdot \sum Y-\sum X \cdot \sum X . Y}{N \cdot \sum X \cdot-\left(\sum X\right)^{2}}$

$b=\frac{\sum X . Y-\frac{\sum X \cdot \sum Y}{N}}{\sum X^{2}-\frac{\left(\sum X\right)^{2}}{N}}$

Keterangan :

$a=$ nilai intercept

$b \quad=$ slope $\Delta \mathrm{Y} / \Delta \mathrm{X}$ (koefisien arah regresi)

$X=$ nilai variabel 1 (variabel pengaruh/independent)

$Y=$ nilai variabel 2 (variabel dependent)

$N=$ banyaknya pasang data / pengukuran / sampel 
2. Kegunaan
a. Mengetahui rumus prediksi suatu variabel
b. Menguji keberartian regresi
c. Menguji linieritas regresi
d. Mengetahui kontribusi (sumbangan)

3. Persyaratan
a. Data berskala interval atau rasio
b. Data berdistribusi normal

4. Penerapan

Suatu penelitian yang mengkaitkan antara kaulitas air (parameter $\mathrm{pH}$ ) dengan jarak sumber air dengan sumber pencemar, didapatkan data sebagai berikut :

\begin{tabular}{|c|c|c|}
\hline $\mathrm{NO}$ & JARAK (X) & $\mathrm{PH}(\mathrm{Y})$ \\
\hline 1 & 4 & 4 \\
\hline 2 & 2 & 2 \\
\hline 3 & 6 & 6 \\
\hline 4 & 7 & 6 \\
\hline 5 & 11 & 7 \\
\hline 6 & 4 & 4 \\
\hline 7 & 13 & 9 \\
\hline 8 & 10 & 8 \\
\hline 9 & 7 & 6 \\
\hline 10 & 5 & 3 \\
\hline 11 & 10 & 7 \\
\hline 12 & 9 & 6 \\
\hline 13 & 8 & 6 \\
\hline 14 & 12 & 7 \\
\hline 15 & 13 & 10 \\
\hline 16 & 10 & 8 \\
\hline 17 & 12 & 7 \\
\hline 18 & 9 & 7 \\
\hline 19 & 8 & 7 \\
\hline 20 & 5 & 5 \\
\hline 21 & 8 & 7 \\
\hline 22 & 9 & 8 \\
\hline 23 & 14 & 11 \\
\hline 24 & 15 & 10 \\
\hline 25 & 14 & 9 \\
\hline 26 & 14 & 9 \\
\hline 27 & 16 & 11 \\
\hline 28 & 10 & 7 \\
\hline 29 & 7 & 6 \\
\hline 30 & 6 & 6 \\
\hline
\end{tabular}


Penyelesaian rumus regresi :

\begin{tabular}{|r|r|r|r|r|r|}
\hline \multicolumn{1}{|c|}{ NO } & JARAK $(\mathrm{X})$ & $\mathrm{PH}(\mathrm{Y})$ & \multicolumn{1}{|c|}{$\mathrm{X}^{2}$} & \multicolumn{1}{c|}{$\mathrm{Y}^{2}$} & \multicolumn{1}{c|}{$\mathrm{XY}$} \\
\hline 1 & 4 & 4 & 16 & 16 & 16 \\
\hline 2 & 2 & 2 & 4 & 4 & 4 \\
\hline 3 & 6 & 6 & 36 & 36 & 36 \\
\hline 4 & 7 & 6 & 49 & 36 & 42 \\
\hline 5 & 11 & 7 & 121 & 49 & 77 \\
\hline 6 & 4 & 4 & 16 & 16 & 16 \\
\hline 7 & 13 & 9 & 169 & 81 & 117 \\
\hline 8 & 10 & 8 & 100 & 64 & 80 \\
\hline 9 & 7 & 6 & 49 & 36 & 42 \\
\hline 10 & 5 & 3 & 25 & 9 & 15 \\
\hline 11 & 10 & 7 & 100 & 49 & 70 \\
\hline 12 & 9 & 6 & 81 & 36 & 54 \\
\hline 13 & 8 & 6 & 64 & 36 & 48 \\
\hline 14 & 12 & 7 & 144 & 49 & 84 \\
\hline 15 & 13 & 10 & 169 & 100 & 130 \\
\hline 16 & 10 & 8 & 100 & 64 & 80 \\
\hline 17 & 12 & 7 & 144 & 49 & 84 \\
\hline 18 & 9 & 7 & 81 & 49 & 63 \\
\hline 19 & 8 & 7 & 64 & 49 & 56 \\
\hline 20 & 5 & 5 & 25 & 25 & 25 \\
\hline 21 & 8 & 7 & 64 & 49 & 56 \\
\hline 22 & 9 & 8 & 81 & 64 & 72 \\
\hline 23 & 14 & 11 & 196 & 121 & 154 \\
\hline 24 & 15 & 10 & 225 & 100 & 150 \\
\hline 25 & 14 & 9 & 196 & 81 & 126 \\
\hline 26 & 14 & 9 & 196 & 81 & 126 \\
\hline 27 & 16 & 11 & 256 & 121 & 176 \\
\hline 28 & 10 & 7 & 100 & 49 & 70 \\
\hline 29 & 7 & 6 & 49 & 36 & 42 \\
\hline 30 & 6 & 6 & 36 & 36 & 36 \\
\hline JUMLAH & 278 & 209 & 2.956 & 1.591 & 2.147 \\
\hline & & & & & \\
\hline
\end{tabular}

$a=\bar{Y}-b \bar{X}=\frac{\sum X^{2} \cdot \sum Y-\sum X \cdot \sum X . Y}{N \cdot \sum X^{2}-\left(\sum X\right)^{2}}$

$a=\bar{Y}-b \bar{X}=\frac{2956.209-278.2147}{30.2956-(278)^{2}}$

$a=\bar{Y}-b \bar{X}=1,8373$

$$
b=\frac{\sum X . Y-\frac{\sum X \cdot \sum Y}{N}}{\sum X^{2}-\frac{\left(\sum X\right)^{2}}{N}}
$$




$$
\begin{aligned}
& b=\frac{2147-\frac{278.209}{30}}{2956-\frac{(278)^{2}}{30}} \\
& b=0,5535 \\
& Y=a+b X \\
& \mathrm{Y}=1,8373+0,5535 \mathrm{X}
\end{aligned}
$$

Uji Independensi

$$
\begin{aligned}
& t=\frac{b-0}{S E_{b}} \\
& S E_{b}=\sqrt{\frac{S_{Y X}^{2}}{\sum X^{2}-\frac{\left(\sum X\right)^{2}}{N}}} \\
& S_{Y X}^{2}=\frac{\sum Y^{2}-a \cdot \sum Y-b \cdot \sum X . Y}{N-2}
\end{aligned}
$$

Penyelesaian :

\section{a. Hipotesis}

Ho : $\beta=0 \approx Y$ tidak terikat (independent) terhadap $\mathrm{X}$ Ha $: \beta \neq 0 \approx Y$ terikat (dependent) terhadap $X$

b. Level signifikansi

$$
\alpha=1 \%=0,01
$$

c. Rumus statistik penguji

$$
\begin{aligned}
& t=\frac{b-0}{S E_{b}} \\
& S E_{b}=\sqrt{\frac{S_{Y X}^{2}}{\sum X^{2}-\frac{\left(\sum X\right)^{2}}{N}}} \\
& S_{Y X}^{2}=\frac{\sum Y^{2}-a \cdot \sum Y-b \cdot \sum X . Y}{N-2}
\end{aligned}
$$


d. Hitung rumus statistik penguji

\begin{tabular}{|c|c|c|c|c|c|}
\hline NO & JARAK (X) & $\mathrm{PH}(\mathrm{Y})$ & $\mathrm{X}^{2}$ & $\mathrm{Y}^{2}$ & $X Y$ \\
\hline 1 & 4 & 4 & 16 & 16 & 16 \\
\hline 2 & 2 & 2 & 4 & 4 & 4 \\
\hline 3 & 6 & 6 & 36 & 36 & 36 \\
\hline 4 & 7 & 6 & 49 & 36 & 42 \\
\hline 5 & 11 & 7 & 121 & 49 & 77 \\
\hline 6 & 4 & 4 & 16 & 16 & 16 \\
\hline 7 & 13 & 9 & 169 & 81 & 117 \\
\hline 8 & 10 & 8 & 100 & 64 & 80 \\
\hline 9 & 7 & 6 & 49 & 36 & 42 \\
\hline 10 & 5 & 3 & 25 & 9 & 15 \\
\hline 11 & 10 & 7 & 100 & 49 & 70 \\
\hline 12 & 9 & 6 & 81 & 36 & 54 \\
\hline 13 & 8 & 6 & 64 & 36 & 48 \\
\hline 14 & 12 & 7 & 144 & 49 & 84 \\
\hline 15 & 13 & 10 & 169 & 100 & 130 \\
\hline 16 & 10 & 8 & 100 & 64 & 80 \\
\hline 17 & 12 & 7 & 144 & 49 & 84 \\
\hline 18 & 9 & 7 & 81 & 49 & 63 \\
\hline 19 & 8 & 7 & 64 & 49 & 56 \\
\hline 20 & 5 & 5 & 25 & 25 & 25 \\
\hline 21 & 8 & 7 & 64 & 49 & 56 \\
\hline 22 & 9 & 8 & 81 & 64 & 72 \\
\hline 23 & 14 & 11 & 196 & 121 & 154 \\
\hline 24 & 15 & 10 & 225 & 100 & 150 \\
\hline 25 & 14 & 9 & 196 & 81 & 126 \\
\hline 26 & 14 & 9 & 196 & 81 & 126 \\
\hline 27 & 16 & 11 & 256 & 121 & 176 \\
\hline 28 & 10 & 7 & 100 & 49 & 70 \\
\hline 29 & 7 & 6 & 49 & 36 & 42 \\
\hline 30 & 6 & 6 & 36 & 36 & 36 \\
\hline JUMLAH & 278 & 209 & 2.956 & 1.591 & 2.147 \\
\hline
\end{tabular}

$$
\begin{aligned}
S_{Y X}^{2} & =\frac{\sum Y^{2}-a \cdot \sum Y-b \cdot \sum X . Y}{N-2} \\
S_{Y X}^{2} & =\frac{1591-1,8373.209-0,5535.2147}{30-2} \\
S_{Y X}^{2} & =0,6657 \\
S E_{b} & =\sqrt{\frac{S_{Y X}^{2}}{\sum X^{2}-\frac{\left(\sum X\right)^{2}}{N}}}
\end{aligned}
$$


$S E_{b}=\sqrt{\frac{0,6657}{2956-\frac{(278)^{2}}{30}}}$

$S E_{b}=0,0419$

$t=\frac{b-0}{S E_{b}}$

$t=\frac{0,5535}{0,0419}$

$t=13,2100$

e. $\mathrm{Df} / \mathrm{dk} / \mathrm{db}$

$\mathrm{Df}=\mathrm{N}-2=30-2=28$

f. Nilai tabel

Nilai tabel pada tabel $\mathrm{t}$

Uji dua sisi, $\alpha=1 \%$, df $=28$, nilai t tabel $= \pm 2,763$

g. Daerah penolakan

1). Menggunakan gambar

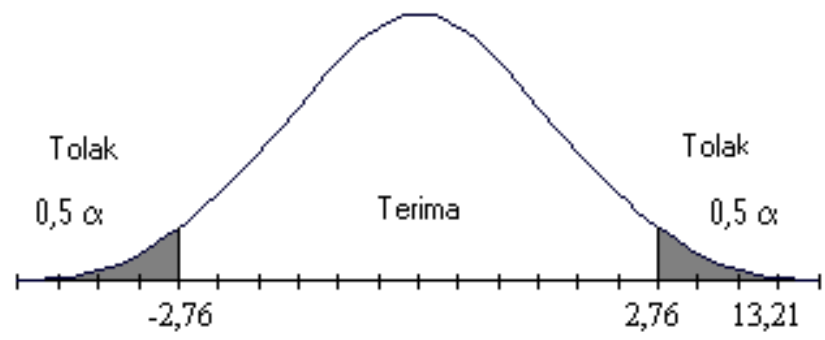

2). Menggunakan rumus

$|13,2100|>|2,763|$; berarti Ho ditolak, Ha diterima

h. Kesimpulan

Variabel kualitas air $(\mathrm{pH})$ (dependent variable/Y) terikat terhadap variabel jarak sumber air dengan sumber pencemar (independent variable/X), pada $\alpha=1 \%$. 
Uji Keberartian dan Linearitas

\begin{tabular}{|c|c|c|c|c|}
\hline $\begin{array}{l}\text { SUMBER } \\
\text { VARIASI }\end{array}$ & $\mathrm{db}$ & JUMLAH KUADRAT & $\mathrm{KT}=\mathrm{RJK}$ & $\mathrm{F}$ \\
\hline Total & $\mathrm{n}$ & $\mathrm{JK}_{\mathrm{T}}=\Sigma \mathrm{Y}^{2}$ & & \\
\hline $\begin{array}{l}\text { Koefisien } \\
\text { (a) }\end{array}$ & 1 & $J K_{a}=\frac{\left(\sum Y\right)^{2}}{n}$ & $J K_{a}=\frac{\left(\sum Y\right)^{2}}{n}$ & $\frac{S_{r e g}^{2}}{S_{s i s}^{2}}$ \\
\hline $\begin{array}{l}\text { Regresi } \\
\text { (b/a) }\end{array}$ & 1 & $J K_{b / a}=\frac{n \cdot \sum X \cdot Y-\sum X \cdot \sum Y}{n \sum X^{2}-\left(\sum X\right)^{2}}$ & $J K_{b / a}=S_{r e g}^{2}$ & keberartian \\
\hline Sisa & $n-2$ & $\mathrm{JK}_{\mathrm{S}}=\mathrm{JK}_{\mathrm{T}}-\mathrm{JK}_{\mathrm{a}}-\mathrm{JK}_{\mathrm{b} / \mathrm{a}}$ & $\frac{J K_{S}}{n-2}=S_{s i s}^{2}$ & \\
\hline Tuna cocok & $\mathrm{k}-2$ & $\mathrm{JK}_{\mathrm{TC}}=\mathrm{JK}_{\mathrm{S}}-\mathrm{JK}_{\mathrm{E}}$ & $\frac{J K_{T C}}{k-2}=S_{T C}^{2}$ & $\frac{S_{T C}^{2}}{S_{E}^{2}}$ \\
\hline $\begin{array}{l}\text { Error atau } \\
\text { galat }\end{array}$ & $\mathrm{n}-\mathrm{k}$ & $J K_{E}=J K_{G}=\sum\left\{\sum Y^{2}-\frac{\left(\sum Y\right)^{2}}{n}\right.$ & $\frac{J K_{E}}{n-k}=S_{E}^{2}=S_{G}^{2}$ & linearitas \\
\hline
\end{tabular}

Uji Keberartian

a. Hipotesis

Ho : koefisien arah regresi $b=0 \approx$ tidak berarti

$\mathrm{Ha}$ : koefisien arah regresi $b \neq 0 \approx$ berarti

b. Level signifikansi

$\alpha=1 \%=0,01$

c. Rumus statistik penguji

\begin{tabular}{|l|l|l|l|l|}
\hline $\begin{array}{l}\text { SUMBER } \\
\text { VARIASI }\end{array}$ & $\mathrm{db}$ & $\mathrm{JUMLAH}$ KUADRAT & $\mathrm{KT}=\mathrm{RJK}$ & $\mathrm{F}$ \\
\hline Total & $\mathrm{n}$ & $\mathrm{JK}_{\mathrm{T}}=\Sigma \mathrm{Y}^{2}$ & & \\
\hline $\begin{array}{l}\text { Koefisien } \\
\text { (a) }\end{array}$ & 1 & $J K_{a}=\frac{\left(\sum Y\right)^{2}}{n}$ & $J K_{a}=\frac{\left(\sum Y\right)^{2}}{n}$ & $\frac{S_{r e g}^{2}}{S_{\text {sis }}^{2}}$ \\
$\begin{array}{l}\text { Regresi } \\
\text { (b/a) }\end{array}$ & 1 & $J K_{b / a}=\frac{n \cdot \sum X \cdot Y-\sum X \cdot \sum Y}{n \sum X^{2}-\left(\sum X\right)^{2}}$ & $J K_{b / a}=S_{r e g}^{2}$ & keberartian \\
Sisa & $\mathrm{n}-2$ & $\mathrm{JK}_{\mathrm{S}}=\mathrm{JK}_{\mathrm{T}}-\mathrm{JK}_{\mathrm{a}}-\mathrm{JK}_{\mathrm{b} / \mathrm{a}}$ & $\frac{J K_{S}}{n-2}=S_{\text {sis }}^{2}$ & \\
\hline
\end{tabular}


d. Hitung rumus statistik penguji

\begin{tabular}{|c|c|c|c|c|c|}
\hline $\mathrm{NO}$ & JARAK (X) & $\mathrm{PH}(\mathrm{Y})$ & $\mathrm{X}^{2}$ & $\mathrm{Y}^{2}$ & $X Y$ \\
\hline 1 & 4 & 4 & 16 & 16 & 16 \\
\hline 2 & 2 & 2 & 4 & 4 & 4 \\
\hline 3 & 6 & 6 & 36 & 36 & 36 \\
\hline 4 & 7 & 6 & 49 & 36 & 42 \\
\hline 5 & 11 & 7 & 121 & 49 & 77 \\
\hline 6 & 4 & 4 & 16 & 16 & 16 \\
\hline 7 & 13 & 9 & 169 & 81 & 117 \\
\hline 8 & 10 & 8 & 100 & 64 & 80 \\
\hline 9 & 7 & 6 & 49 & 36 & 42 \\
\hline 10 & 5 & 3 & 25 & 9 & 15 \\
\hline 11 & 10 & 7 & 100 & 49 & 70 \\
\hline 12 & 9 & 6 & 81 & 36 & 54 \\
\hline 13 & 8 & 6 & 64 & 36 & 48 \\
\hline 14 & 12 & 7 & 144 & 49 & 84 \\
\hline 15 & 13 & 10 & 169 & 100 & 130 \\
\hline 16 & 10 & 8 & 100 & 64 & 80 \\
\hline 17 & 12 & 7 & 144 & 49 & 84 \\
\hline 18 & 9 & 7 & 81 & 49 & 63 \\
\hline 19 & 8 & 7 & 64 & 49 & 56 \\
\hline 20 & 5 & 5 & 25 & 25 & 25 \\
\hline 21 & 8 & 7 & 64 & 49 & 56 \\
\hline 22 & 9 & 8 & 81 & 64 & 72 \\
\hline 23 & 14 & 11 & 196 & 121 & 154 \\
\hline 24 & 15 & 10 & 225 & 100 & 150 \\
\hline 25 & 14 & 9 & 196 & 81 & 126 \\
\hline 26 & 14 & 9 & 196 & 81 & 126 \\
\hline 27 & 16 & 11 & 256 & 121 & 176 \\
\hline 28 & 10 & 7 & 100 & 49 & 70 \\
\hline 29 & 7 & 6 & 49 & 36 & 42 \\
\hline 30 & 6 & 6 & 36 & 36 & 36 \\
\hline JUMLAH & 278 & 209 & 2.956 & 1.591 & 2.147 \\
\hline
\end{tabular}

$\mathrm{JK}_{\mathrm{T}}=\Sigma \mathrm{Y}^{2}$

$\mathrm{JK}_{\mathrm{T}}=1591$

$$
\begin{aligned}
& J K_{a}=\frac{\left(\sum Y\right)^{2}}{n} \\
& J K_{a}=\frac{(209)^{2}}{30}
\end{aligned}
$$




$$
\begin{aligned}
& J K_{a}=1456,0333 \\
& J K_{b / a}=\frac{n \cdot \sum X \cdot Y-\sum X \cdot \sum Y}{n \sum X^{2}-\left(\sum X\right)^{2}} \\
& J K_{b / a}=\frac{30.2147-278.209}{30.2956-278^{2}} \\
& J K_{b / a}=0,5535 \\
& \mathrm{JK}_{\mathrm{S}}=\mathrm{JK}_{\mathrm{T}}-\mathrm{JK}_{\mathrm{a}}-\mathrm{JK}_{\mathrm{b} / \mathrm{a}} \\
& \mathrm{JK}_{\mathrm{S}}=1591-1456,0333-0,5535 \\
& \mathrm{JK}_{\mathrm{S}}=134,4123 \\
& J K_{b / a}=S_{r e g}^{2} \\
& S_{\text {reg }}^{2}=0,5535 \\
& \frac{J K_{S}}{n-2}=S_{s i s}^{2} \\
& \frac{134,4123}{30-2}=S_{\text {sis }}^{2} \\
& S_{\text {sis }}^{2}=4,8005 \\
& F=\frac{S_{r e g}^{2}}{S_{\text {sis }}^{2}} \\
& F=\frac{0,5535}{4,8005} \\
& F=0,1153
\end{aligned}
$$

e. $\mathrm{Df} / \mathrm{dk} / \mathrm{db}$

Df $=1 ; \mathrm{N}-2=30-2=28 \approx 1 ; 28$

f. Nilai tabel

Nilai tabel pada tabel $\mathrm{F}$

$\alpha=1 \%$, df $=1 ; 28$, nilai $F$ tabel $=7,64$

g. Daerah penolakan 
1). Menggunakan gambar

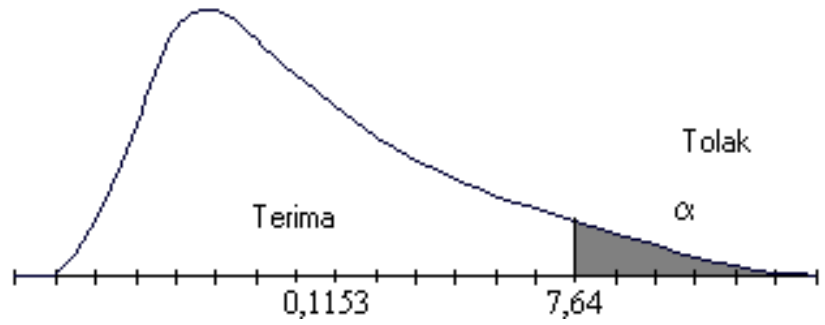

2). Menggunakan rumus

$|0,1153|<|7,64|$; berarti Ho diterima, Ha ditolak

h. Kesimpulan

Koefisien arah regresi tidak berarti, pada $\alpha=1 \%$.

Uji Linearitas

a. Hipotesis

Ho : bentuk regresi linear

$\mathrm{Ha}$ : bentuk regresi non linear

b. Level signifikansi

$\alpha=1 \%=0,01$

c. Rumus statistik penguji

\begin{tabular}{|c|c|c|c|c|}
\hline $\begin{array}{l}\text { SUMBER } \\
\text { VARIASI }\end{array}$ & $\mathrm{db}$ & JUMLAH KUADRAT & $\mathrm{KT}=\mathrm{RJK}$ & $\mathrm{F}$ \\
\hline Total & $\mathrm{n}$ & $\mathrm{JK}_{\mathrm{T}}=\Sigma \mathrm{Y}^{2}$ & & \\
\hline $\begin{array}{l}\text { Koefisien } \\
\text { (a) }\end{array}$ & 1 & $J K_{a}=\frac{\left(\sum Y\right)^{2}}{n}$ & $J K_{a}=\frac{\left(\sum Y\right)^{2}}{n}$ & $\frac{S_{r e g}^{2}}{S_{s i s}^{2}}$ \\
\hline $\begin{array}{l}\text { Regresi } \\
\text { (b/a) }\end{array}$ & 1 & $J K_{b / a}=\frac{n \cdot \sum X . Y-\sum X \cdot \sum Y}{n \sum X^{2}-\left(\sum X\right)^{2}}$ & $J K_{b / a}=S_{r e g}^{2}$ & keberartian \\
\hline Sisa & $n-2$ & $\mathrm{JK}_{\mathrm{S}}=\mathrm{JK}_{\mathrm{T}}-\mathrm{JK}_{\mathrm{a}}-\mathrm{JK}_{\mathrm{b} / \mathrm{a}}$ & $\frac{J K_{S}}{n-2}=S_{s i s}^{2}$ & \\
\hline Tuna cocok & $\mathrm{k}-2$ & $\mathrm{JK}_{\mathrm{TC}}=\mathrm{JK}_{\mathrm{S}}-\mathrm{JK}_{\mathrm{E}}$ & $\frac{J K_{T C}}{k-2}=S_{T C}^{2}$ & $\frac{S_{T C}^{2}}{S_{E}^{2}}$ \\
\hline $\begin{array}{l}\text { Error atau } \\
\text { galat }\end{array}$ & $\mathrm{n}-\mathrm{k}$ & $J K_{E}=J K_{G}=\sum\left\{\sum Y^{2}-\frac{\left(\sum Y\right.}{n}\right.$ & $\frac{J K_{E}}{n-k}=S_{E}^{2}=\$$ & linearitas \\
\hline
\end{tabular}


d. Hitung rumus statistik penguji

Nilai variabel $X$ diurutkan

\begin{tabular}{|c|c|c|c|c|c|c|c|}
\hline $\mathrm{NO}$ & JARAK (X) & $\mathrm{KLP}(\mathrm{k})$ & $\mathrm{n}_{\mathrm{i}}$ & $\mathrm{PH}(\mathrm{Y})$ & $X^{2}$ & $\mathrm{Y}^{2}$ & $\mathrm{XY}$ \\
\hline 2 & 2 & \begin{tabular}{|l|}
1 \\
\end{tabular} & 1 & 2 & 4 & 4 & 4 \\
\hline 1 & 4 & 2 & \multirow[t]{2}{*}{2} & 4 & 16 & 16 & 16 \\
\hline 6 & 4 & 2 & & 4 & 16 & 16 & 16 \\
\hline 10 & 5 & 3 & \multirow[t]{2}{*}{2} & 3 & 25 & 9 & 15 \\
\hline 20 & 5 & 3 & & 5 & 25 & 25 & 25 \\
\hline 3 & 6 & 4 & \multirow[t]{2}{*}{2} & 6 & 36 & 36 & 36 \\
\hline 30 & 6 & 4 & & 6 & 36 & 36 & 36 \\
\hline 4 & 7 & 5 & \multirow{3}{*}{3} & 6 & 49 & 36 & 42 \\
\hline 9 & 7 & 5 & & 6 & 49 & 36 & 42 \\
\hline 29 & 7 & 5 & & 6 & 49 & 36 & 42 \\
\hline 13 & 8 & 6 & \multirow{3}{*}{3} & 6 & 64 & 36 & 48 \\
\hline 19 & 8 & 6 & & 7 & 64 & 49 & 56 \\
\hline 21 & 8 & 6 & & 7 & 64 & 49 & 56 \\
\hline 12 & 9 & 7 & \multirow{3}{*}{3} & 6 & 81 & 36 & 54 \\
\hline 18 & 9 & 7 & & 7 & 81 & 49 & 63 \\
\hline 22 & 9 & 7 & & 8 & 81 & 64 & 72 \\
\hline 8 & 10 & 8 & \multirow[t]{4}{*}{4} & 8 & 100 & 64 & 80 \\
\hline 11 & 10 & 8 & & 7 & 100 & 49 & 70 \\
\hline 16 & 10 & 8 & & 8 & 100 & 64 & 80 \\
\hline 28 & 10 & 8 & & 7 & 100 & 49 & 70 \\
\hline 5 & 11 & 9 & 1 & 7 & 121 & 49 & 77 \\
\hline 14 & 12 & 10 & \multirow[t]{2}{*}{2} & 7 & 144 & 49 & 84 \\
\hline 17 & 12 & 10 & & 7 & 144 & 49 & 84 \\
\hline 7 & 13 & 11 & \multirow[t]{2}{*}{2} & 9 & 169 & 81 & 117 \\
\hline 15 & 13 & 11 & & 10 & 169 & 100 & 130 \\
\hline 23 & 14 & 12 & \multirow{3}{*}{3} & 11 & 196 & 121 & 154 \\
\hline 25 & 14 & 12 & & 9 & 196 & 81 & 126 \\
\hline 26 & 14 & 12 & & 9 & 196 & 81 & 126 \\
\hline 24 & 15 & 13 & 1 & 10 & 225 & 100 & 150 \\
\hline 27 & 16 & 14 & 1 & 11 & 256 & 121 & 176 \\
\hline JML & 278 & & 30 & 209 & 2.956 & 1.591 & 2.147 \\
\hline
\end{tabular}

\begin{tabular}{|l|c|l|c|c|}
\hline $\begin{array}{l}\text { SUMBER } \\
\text { VARIASI }\end{array}$ & $\mathrm{db}$ & JUMLAH KUADRAT & $\mathrm{KT}=\mathrm{RJK}$ & $\mathrm{F}$ \\
\hline Total & $\mathrm{n}$ & 1591 & & \\
\hline Koefisien (a) & 1 & 1456,0333 & 1456,0333 & 0,1153 \\
Regresi (b/a) & 1 & 0,5535 & 0,5535 & keberartian \\
Sisa & 28 & 134,4123 & 4,8005 & \\
\hline Tuna cocok & $\mathrm{k}-2$ & $\mathrm{JK}_{\mathrm{TC}}=\mathrm{JK}_{\mathrm{S}}-\mathrm{JK}_{\mathrm{E}}$ & $\frac{J K_{T C}}{k-2}=S_{T C}^{2}$ & $\frac{S_{T C}^{2}}{S_{r}^{2}}$ \\
& & & &
\end{tabular}




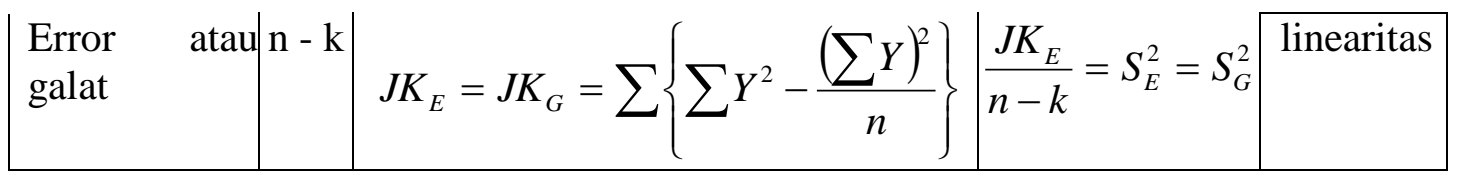

$$
\begin{aligned}
& J K_{E}=J K_{G}=\sum\left\{\sum Y^{2}-\frac{\left(\sum Y\right)^{2}}{n_{i}}\right\} \\
& J K_{E}=J K_{G}=\left(2^{2}-\frac{2^{2}}{1}\right)+\left(4^{2}+4^{2}-\frac{(4+4)^{2}}{2}\right)+\left(3^{2}+5^{2}-\frac{(3+5)^{2}}{2}\right)+ \\
& \left(6^{2}+6^{2}-\frac{(6+6)^{2}}{2}\right)+\left(6^{2}+6^{2}+6^{2}-\frac{(6+6+6)^{2}}{3}\right)+\left(6^{2}+7^{2}+7^{2}-\frac{(6+7+7)^{2}}{3}\right)+ \\
& \left(6^{2}+7^{2}+8^{2}-\frac{(6+7+8)^{2}}{3}\right)+\left(7^{2}+7^{2}+8^{2}+8^{2}-\frac{(7+7+8+8)^{2}}{4}\right)+ \\
& \left(7^{2}+7^{2}-\frac{(7+7)^{2}}{2}\right)+\left(9^{2}+10^{2}-\frac{(9+10)^{2}}{2}\right)+\left(9^{2}+9^{2}+11^{2}-\frac{(9+9+11)^{2}}{3}\right)+ \\
& \left(10^{2}-\frac{10^{2}}{1}\right)+\left(11^{2}-\frac{11^{2}}{1}\right) \\
& J K_{E}=J K_{G}=11,8334 \\
& \mathrm{JK}_{\mathrm{TC}}=\mathrm{JK}_{\mathrm{S}}-\mathrm{JK}_{\mathrm{E}} \\
& \mathrm{JK}_{\mathrm{TC}}=134,4123-11,8334 \\
& \mathrm{JK}_{\mathrm{TC}}=122,5789 \\
& \frac{J K_{T C}}{k-2}=S_{T C}^{2} \\
& \frac{122,5789}{14-2}=S_{T C}^{2} \\
& S_{T C}^{2}=10,2149 \\
& \frac{J K_{E}}{n-k}=S_{E}^{2}=S_{G}^{2} \\
& \frac{11,8334}{30-14}=S_{E}^{2}=S_{G}^{2} \\
& S_{E}^{2}=S_{G}^{2}=0,7396 \\
& F=\frac{S_{T C}^{2}}{S_{E}^{2}} \\
& F=\frac{10,2149}{0,7396}
\end{aligned}
$$




$$
F=13,8116
$$

e. $\mathrm{Df} / \mathrm{dk} / \mathrm{db}$

$\mathrm{Df}=\mathrm{k}-2 ; \mathrm{N}-\mathrm{k}=14-2 ; 30-14=12 ; 16$

f. Nilai tabel

Nilai tabel pada tabel $\mathrm{F}$

$\alpha=1 \%, \mathrm{df}=12 ; 16$ nilai $\mathrm{F}$ tabel $=3,55$

g. Daerah penolakan

1). Menggunakan gambar

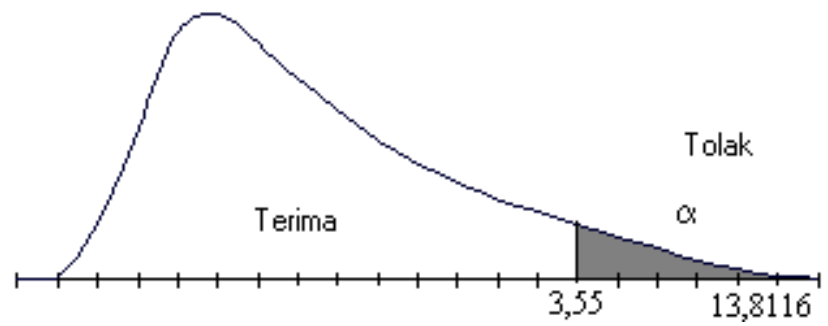

2). Menggunakan rumus

$|13,8116|>|3,55|$; berarti Ho ditolak, Ha diterima

h. Kesimpulan

Bentuk regresi non linear, pada $\alpha=1 \%$.

Kontribusi (Sumbangan)

Kontribusi variabel $\mathrm{X}$ terhadap $\mathrm{Y}$ adalah sama dengan koefisien determinasi $r_{X Y}^{2}$ yang dinyatakan dalam persentase, yaitu $0,929^{2}=0,8630=86 \%$.

$$
\begin{aligned}
& S S_{\text {reg }}=r_{X Y}^{2} \cdot \sum y^{2}=0,8630 \cdot 134,9667=116,4763 \\
& S S_{r e s}=\left(1-r_{X Y}^{2}\right) \cdot \sum y^{2}=(1-0,8630) \cdot 134,9667=18,4904 \\
& S S_{t o t}=S S_{r e g}+S S_{r e s}=116,4763+18,4904=134,9667 \\
& \sum y^{2}=S S_{y}=\sum Y^{2}-\frac{\left(\sum Y\right)}{N}=1591-\frac{209^{2}}{30}=134,9667
\end{aligned}
$$




\section{DAFTAR PUSTAKA}

Arikunto, Suharsimi, 1993, Prosedur Penelitian Suatu Pendekatan Praktik edisi revisi II cetakan ke sembilan, Jakarta : PT. Rineka Cipta.

Burhan, Safrida, 1995, Metodologi Penelitian dan Pedoman Penulisan Karya Tulis, Bandung : Akademi Keperawatan Pajajaran.

Conover, W.J, 1980, Practical Nonparametric Statistics second edition, New York : John Wiley \& Sons.

Hadi, Sutrisno, 1993, Statistik jilid II cetakan XIV, Yogyakarta : Andi Offset.

Hall, Marguerite. F, 1949, Public Health Statistics, New York : Paul B Horber Inc

Nasir, Moh, 1985, Metode Penelitian cetakan pertama, Jakarta : Ghalia Indonesia.

Poerwadi, Troeboes. Joesoef, Aboe Amar dan Widjaja, Linardi, 1993, Metode Penelitian dan Statistik Terapan / editor, Surabaya : Airlangga University Press.

Siegel, Sidney, 1956, Non Parametric Statistics For The Behavioral Sciences, New York : Mc Graw-Hill Book Company.

Siegel, Sidney, 1986, Statistik Non Parametrik Untuk Ilmu-Ilmu Sosial, diterjemahkan oleh Zanzawi Suyuti dan Landung Simatupang dalam koordinasi Peter Hagul, Cetakan ke 2, Jakarta : Gramedia.

Singarimbun, Masri dan Effendi Sofian, 1989, Metode Penelitian Survei / editor, Jakarta : LP3ES.

Snedecor, George W dan Cochran, William G, 1980, Statistical Methods seventh edition, Ames Iowa USA : The Iowa State University Press

Soejoeti, Zanzawi, 1984/1985, Buku Materi Pokok Metode Statistik I STA 201/3 SKS/Modul 1-5, Jakarta : Universitas Terbuka, Departemen Pendidikan dan Kebudayaan.

Soejoeti, Zanzawi, 1984/1985, Buku Materi Pokok Metode Statistik I STA 201/3 SKS/Modul 6-9, Jakarta : Universitas Terbuka, Departemen Pendidikan dan Kebudayaan.

Soejoeti, Zanzawi, 1984/1985, Buku Materi Pokok Metode Statistik II STA 202/3 SKS/Modul 15, Jakarta : Universitas Terbuka, Departemen Pendidikan dan Kebudayaan.

Soejoeti, Zanzawi, 1985, Buku Materi Pokok Metode Statistik II STA 202/3 SKS/Modul 6-9, Jakarta : Universitas Terbuka, Departemen Pendidikan dan Kebudayaan.

Soepeno, Bambang, 1997, Statistik Terapan (Dalam Penelitian Ilmu-Ilmu Sosial dan Pendidikan), Jakarta ; PT. Rineka Cipta

Sujana, 1992, Metoda Statistika, edisi ke 5, Bandung : Tarsito.

Tjokronegoro, Arjatmo. Utomo, Budi, dan Rukmono, Bintari, (editor), 1991, Dasar-Dasar Metodologi Riset Ilmu Kedokteran, Jakarta : Departemen Pendidikan dan Kebudayaan Konsorsium Ilmu Kedokteran 
Lampiran 1 : Tabel Distribusi Normal

\begin{tabular}{|c|c|c|c|c|c|c|c|c|c|c|}
\hline $\mathrm{Z}$ & 0,00 & 0,01 & 0,02 & 0,03 & 0,04 & 0,05 & 0,06 & 0,07 & 0,08 & 0,09 \\
\hline 0,0 & 0,5000 & 0,4960 & 0,4920 & 0,4880 & 0,4840 & 0,4801 & 0,4761 & 0,4721 & 0,4681 & 0,4641 \\
\hline 0,1 & 0,4602 & 0,4562 & 0,4522 & 0,4483 & & & 0,4364 & 0,4325 & 0,4286 & 0,4247 \\
\hline 0,2 & 0,4207 & 0,4168 & 0,4129 & 0,4090 & 0,4052 & 0,4013 & 0,3974 & 0,3936 & 0,3897 & 0,3859 \\
\hline 0,3 & 0,3821 & 0,3783 & 0,3745 & 0,3707 & 0,3669 & 0,3632 & 0,3594 & 0,3557 & 0,3520 & 0,3483 \\
\hline 0,4 & 0,3446 & 0,3409 & 0,3372 & 0,3336 & 0,3300 & 0,3264 & 0,3228 & 0,3192 & 0,3156 & 0,3121 \\
\hline 0,5 & 0,3085 & 0,3050 & 0,3015 & 0,2981 & 0,2946 & 0,2912 & 0,2877 & 0,2843 & 0,2810 & 0,2776 \\
\hline 0,6 & ,2743 & & & & & & 0,2546 & & 0,2483 & 0,2451 \\
\hline 0,7 & & & & & & & & & 0,2177 & 0,2148 \\
\hline 0,8 & 2119 & & & & & & & 0,1922 & 0,1894 & 0,1867 \\
\hline 0,9 & & & & & & & & 0,1660 & 0,1635 & 0,1611 \\
\hline 1,0 & 0,1587 & 0,1562 & 0,1539 & 0,1515 & 0,1492 & 0,1469 & 446 & 0,1423 & 0,1401 & 0,1379 \\
\hline 1,1 & 0,1357 & & & 0,1292 & & & 0,1230 & 0,12 & 0,1190 & \\
\hline 1,2 & & & & & & & 0,1038 & & 0,1003 & \\
\hline 1,3 & & & & & & & & & 0,0838 & \\
\hline 1,4 & 0,0808 & & & & & & & & 0,0694 & 0,0681 \\
\hline 1,5 & 0,0668 & 0,0655 & 0,0643 & 0,0630 & 0,0618 & 0,0606 & 0,0594 & 0,0582 & 0,0571 & 0,0559 \\
\hline 1,6 & 0,0548 & 0,0537 & 0,0526 & 0,0516 & 0,0505 & 0,04 & 0,0485 & 0,0475 & 0,0465 & 0,0455 \\
\hline 1,7 & 0,0446 & 0436 & & 0,0418 & & & 0,0392 & & 0,0375 & \\
\hline 1,8 & & & & & & & & & & \\
\hline 1,9 & 0,0287 & 0,0281 & 0,0274 & 0,0268 & 0,0262 & 0,0256 & 0,0250 & 0,0244 & 0,0239 & 0,0233 \\
\hline 2,0 & 0,0228 & 0,0222 & 0,0217 & 0,0212 & 0,0207 & 0,0202 & 0,0197 & 0,0192 & 0,0188 & 0,0183 \\
\hline 2,1 & 0,0179 & 0,0174 & 0,0170 & 0,0166 & 0,0162 & 0,0158 & 0,0154 & 0,0150 & 0,0146 & 0,0143 \\
\hline 2,2 & 0,0139 & 0,0136 & 0,0132 & 0,0129 & 0,0125 & 0,0122 & 0,0119 & 0,0116 & 0,0113 & 0,0110 \\
\hline 2,3 & & & & & & & & & 0,0087 & 0,0084 \\
\hline 2,4 & 0,0082 & 0,0080 & & & & & & & 0,0066 & \\
\hline 2,5 & 0,0062 & 0,0060 & 0,0059 & 0,0057 & 0,0055 & 0,0054 & 0,0052 & 0,0051 & 0,0049 & 0,0048 \\
\hline 2,6 & 0,0047 & 0,0045 & 0,0044 & 0,0043 & 0,0041 & 0,0040 & 0,0039 & 0,0038 & 0,0037 & 0,0036 \\
\hline 2,7 & & & & & & & 0,0029 & & 0,0027 & 0,0026 \\
\hline 2,8 & & & & & & & & 0,0021 & 0,0020 & 0,0019 \\
\hline 2,9 & 0,0019 & 0,0018 & 0,0018 & 0,0017 & 0,0016 & 0,0016 & 0,0015 & 0,0015 & 0,0014 & 0,0014 \\
\hline 3,0 & 0,0013 & 0,0013 & 0,0013 & 0,0012 & 0,0012 & 0,0011 & 0,0011 & 0,0011 & 0,0010 & 0,0010 \\
\hline 3,1 & 0,0010 & 0,0009 & 0,0009 & 0,0009 & 0,0008 & 0,0008 & 0,0008 & 0,0008 & 0,0007 & 0,0007 \\
\hline 3,2 & 0,0007 & 0,0007 & 0,0006 & 0,0006 & 0,0006 & 0,0006 & 0,0006 & 0,0005 & 0,0005 & 0,0005 \\
\hline 3,3 & 0,0005 & 0,0005 & 0,0005 & 0,0004 & 0,0004 & 0,0004 & 0,0004 & 0,0004 & 0,0004 & 0,0003 \\
\hline 3,4 & 0,0003 & 0,0003 & 0,0003 & 0,0003 & 0,0003 & 0,0003 & 0,0003 & 0,0003 & 0,0003 & 0,0002 \\
\hline 3,5 & 0,0002 & 0,0002 & 0,0002 & 0,0002 & 0,0002 & 0,0002 & 0,0002 & 0,0002 & 0,0002 & 0,0002 \\
\hline 3,6 & 0,0002 & 0,0002 & 0,0001 & 0,0001 & 0,0001 & 0,0001 & 0,0001 & 0,0001 & 0,0001 & 0,0001 \\
\hline 3,7 & 0,0001 & 0,0001 & 0,0001 & 0,0001 & 0,0001 & 0,0001 & 0,0001 & 0,0001 & 0,0001 & 0,0001 \\
\hline 3,8 & 0,0001 & 0,0001 & 0,0001 & 0,0001 & 0,0001 & 0,0001 & 0,0001 & 0,0001 & 0,0001 & 0,0001 \\
\hline
\end{tabular}


Lampiran 2 : Tabel Harga Kritis t

\begin{tabular}{|c|c|c|c|c|c|c|}
\hline \multirow{4}{*}{ df } & \multicolumn{6}{|c|}{ Tingkat Signifikansi untuk tes satu sisi } \\
\hline & 0,100 & 0,050 & 0,025 & 0,010 & 0,005 & 0,0005 \\
\hline & \multicolumn{6}{|c|}{ Tingkat Signifikansi untuk tes dua sisi } \\
\hline & 0,200 & 0,100 & 0,050 & 0,020 & 0,010 & 0,001 \\
\hline 1 & 3,078 & 6,314 & 12,706 & 31,821 & 63,657 & 636,691 \\
\hline 2 & 1,886 & 2,920 & 4,303 & 6,965 & 9,925 & 31,598 \\
\hline 3 & 1,638 & 2,353 & 3,182 & 4,541 & 5,841 & 12,941 \\
\hline 4 & 1,533 & 2,132 & 2,776 & 3,747 & 4,604 & 8,610 \\
\hline 5 & 1,476 & 2,015 & 2,571 & 3,365 & 4,032 & 6,859 \\
\hline 6 & 1,440 & 1,943 & 2,447 & 3,143 & 3,707 & 5,959 \\
\hline 7 & 1,415 & 1,985 & 2,365 & 2,998 & 3,499 & 5,405 \\
\hline 8 & 1,397 & 1,860 & 2,306 & 2,896 & 3,355 & 4,041 \\
\hline 9 & 1,383 & 1,833 & 2,262 & 2,821 & 3,250 & 4,781 \\
\hline 10 & 1,372 & 1,812 & 2,228 & 2,764 & 3,160 & 4,587 \\
\hline 11 & 1,363 & 1,796 & 2,201 & 2,718 & 3,106 & 4,437 \\
\hline 12 & 1,356 & 1,782 & 2,179 & 2,681 & 3,055 & 4,318 \\
\hline 13 & 1,350 & 1,771 & 2,160 & 2,650 & 3,012 & 4,221 \\
\hline 14 & 1,345 & 1,761 & 2,145 & 2,624 & 2,977 & 4,140 \\
\hline 15 & 1,341 & 1,753 & 2,131 & 2,602 & 2,947 & 4,073 \\
\hline 16 & 1,337 & 1,746 & 2,120 & 2,583 & 2,921 & 4,015 \\
\hline 17 & 1,333 & 1,740 & 2,110 & 2,567 & 2,898 & 3,965 \\
\hline 18 & 1,330 & 1,734 & 2,101 & 2,552 & 2,878 & 3,922 \\
\hline 19 & 1,328 & 1,729 & 2,093 & 2,539 & 2,861 & 3,883 \\
\hline 20 & 1,325 & 1,725 & 2,086 & 2,528 & 2,845 & 3,850 \\
\hline 21 & 1,323 & 1,721 & 2,080 & 2,518 & 2,831 & 3,819 \\
\hline 22 & 1,321 & 1,717 & 2,074 & 2,508 & 2,819 & 3,792 \\
\hline 23 & 1,319 & 1,714 & 2,069 & 2,500 & 2,807 & 3,767 \\
\hline 24 & 1,318 & 1,711 & 2,064 & 2,492 & 2,797 & 3,745 \\
\hline 25 & 1,316 & 1,708 & 2,060 & 2,485 & 2,787 & 3,725 \\
\hline 26 & 1,315 & 1,706 & 2,056 & 2,479 & 2,779 & 3,707 \\
\hline 27 & 1,314 & 1,703 & 2,052 & 2,473 & 2,771 & 3,690 \\
\hline 28 & 1,313 & 1,701 & 2,048 & 2,467 & 2,763 & 3,674 \\
\hline 29 & 1,311 & 1,699 & 2,045 & 2,462 & 2,756 & 3,659 \\
\hline 30 & 1,310 & 1,697 & 2,042 & 2,457 & 2,750 & 3,646 \\
\hline 40 & 1,303 & 1,684 & 2,021 & 2,423 & 2,704 & 3,551 \\
\hline 60 & 1,296 & 1,671 & 2,000 & 2,390 & 2,660 & 3,460 \\
\hline 120 & 1,289 & 1,658 & 1,980 & 2,358 & 2,617 & 3,373 \\
\hline$\infty$ & 1,282 & 1,645 & 1,960 & 2,326 & 2,576 & 3,291 \\
\hline
\end{tabular}

Sumber : Nasir, Moh, 1985, Metode Penelitian cetakan pertama, Jakarta : Ghalia Indonesia. 
Lampiran 3 : Tabel Harga Kritis Korelasi Moment Product Pearson ( r )

\begin{tabular}{|c|c|c|c|c|}
\hline \multirow{4}{*}{ df } & \multicolumn{4}{|c|}{ Tingkat Signifikansi untuk tes satu sisi } \\
\hline & 0,050 & 0,025 & 0,010 & 0,005 \\
\hline & \multicolumn{4}{|c|}{ Tingkat Signifikansi untuk tes dua sisi } \\
\hline & 0,100 & 0,050 & 0,020 & 0,010 \\
\hline 1 & 0,988 & 0,997 & 0,9995 & 0,9999 \\
\hline 2 & 0,900 & 0,950 & 0,980 & 0,990 \\
\hline 3 & 0,805 & 0,878 & 0,934 & 0,959 \\
\hline 4 & 0,729 & 0,811 & 0,882 & 0,917 \\
\hline 5 & 0,669 & 0,754 & 0,833 & 0,874 \\
\hline 6 & 0,622 & 0,707 & 0,789 & 0,834 \\
\hline 7 & 0,582 & 0,666 & 0,750 & 0,798 \\
\hline 8 & 0,549 & 0,632 & 0,716 & 0,765 \\
\hline 9 & 0,521 & 0,602 & 0,685 & 0,735 \\
\hline 10 & 0,497 & 0,576 & 0,658 & 0,708 \\
\hline 11 & 0,476 & 0,553 & 0,634 & 0,684 \\
\hline 12 & 0,458 & 0,532 & 0,612 & 0,661 \\
\hline 13 & 0,441 & 0,514 & 0,592 & 0,641 \\
\hline 14 & 0,426 & 0,497 & 0,574 & 0,623 \\
\hline 15 & 0,412 & 0,482 & 0,558 & 0,606 \\
\hline 16 & 0,400 & 0,468 & 0,542 & 0,590 \\
\hline 17 & 0,389 & 0,456 & 0,528 & 0,575 \\
\hline 18 & 0,378 & 0,444 & 0,516 & 0,561 \\
\hline 19 & 0,369 & 0,433 & 0,503 & 0,549 \\
\hline 20 & 0,360 & 0,423 & 0,492 & 0,537 \\
\hline 21 & 0,352 & 0,413 & 0,482 & 0,526 \\
\hline 22 & 0,344 & 0,404 & 0,472 & 0,515 \\
\hline 23 & 0,337 & 0,396 & 0,462 & 0,505 \\
\hline 24 & 0,330 & 0,388 & 0,453 & 0,496 \\
\hline 25 & 0,323 & 0,381 & 0,445 & 0,487 \\
\hline 26 & 0,317 & 0,374 & 0,437 & 0,470 \\
\hline 27 & 0,311 & 0,367 & 0,430 & 0,471 \\
\hline 28 & 0,306 & 0,361 & 0,423 & 0,463 \\
\hline 29 & 0,301 & 0,355 & 0,416 & 0,456 \\
\hline 30 & 0,296 & 0,349 & 0,409 & 0,449 \\
\hline 35 & 0,275 & 0,325 & 0,381 & 0,418 \\
\hline 40 & 0,257 & 0,304 & 0,358 & 0,393 \\
\hline 45 & 0,243 & 0,288 & 0,338 & 0,372 \\
\hline 50 & 0,231 & 0,273 & 0,322 & 0,354 \\
\hline 60 & 0,211 & 0,250 & 0,295 & 0,325 \\
\hline 70 & 0,195 & 0,232 & 0,274 & 0,303 \\
\hline 80 & 0,183 & 0,217 & 0,256 & 0,283 \\
\hline 90 & 0,173 & 0,205 & 0,242 & 0,267 \\
\hline 100 & 0,164 & 0,195 & 0,230 & 0,254 \\
\hline
\end{tabular}

Sumber : Nasir, Moh, 1985, Metode Penelitian cetakan pertama, Jakarta : Ghalia Indonesia. 
Lampiran 4 : Tabel Harga Kritik Korelasi Tata Jenjang Spearman ( rho )

\begin{tabular}{|c|c|c|c|}
\hline \multirow{4}{*}{$\mathrm{N}$} & \multicolumn{3}{|c|}{ Tingkat Signifikansi untuk tes satu sisi } \\
\hline & 0,05 & 0,01 & 0,005 \\
\hline & \multicolumn{3}{|c|}{ Tingkat Signifikansi untuk tes dua sisi } \\
\hline & 0,10 & 0,02 & 0,01 \\
\hline 4 & 1,000 & & \\
\hline 5 & 0,900 & 1,000 & \\
\hline 6 & 0,829 & 0,943 & 1,000 \\
\hline 7 & 0,714 & 0,893 & 0,929 \\
\hline 8 & 0,643 & 0,833 & 0,881 \\
\hline 9 & 0,600 & 0,783 & 0,833 \\
\hline 10 & 0,564 & 0,746 & 0,794 \\
\hline 12 & 0,506 & 0,712 & 0,777 \\
\hline 14 & 0,456 & 0,645 & 0,715 \\
\hline 16 & 0,425 & 0,601 & 0,665 \\
\hline 18 & 0,399 & 0,564 & 0,625 \\
\hline 20 & 0,377 & 0,534 & 0,591 \\
\hline 22 & 0,359 & 0,508 & 0,562 \\
\hline 24 & 0,343 & 0,485 & 0,537 \\
\hline 26 & 0,329 & 0,465 & 0,515 \\
\hline 28 & 0,317 & 0,448 & 0,496 \\
\hline 30 & 0,306 & 0,432 & 0,478 \\
\hline
\end{tabular}

Sumber : Soepeno, Bambang, 1997, Statistik Terapan (Dalam Penelitian Ilmu-Ilmu Sosial dan Pendidikan), Jakarta ; PT. Rineka Cipta 
Lampiran 5 : Tabel Harga Quantil Statistik Lilliefors Distribusi Normal

\begin{tabular}{|l|r|r|r|r|r|r|}
\hline & $\mathrm{N}$ & $\mathrm{p}=0,80$ & $\mathrm{p}=0,85$ & $\mathrm{p}=0,90$ & $\mathrm{p}=0,95$ & $\mathrm{p}=0,99$ \\
\hline Ukuran sampel & 4 & 0,300 & 0,319 & 0,352 & 0,381 & 0,417 \\
\hline & 5 & 0,285 & 0,299 & 0,315 & 0,337 & 0,405 \\
\hline & 6 & 0,265 & 0,277 & 0,294 & 0,319 & 0,364 \\
\hline & 7 & 0,247 & 0,258 & 0,276 & 0,300 & 0,348 \\
\hline & 8 & 0,233 & 0,244 & 0,261 & 0,285 & 0,331 \\
\hline & 9 & 0,223 & 0,233 & 0,249 & 0,271 & 0,311 \\
\hline & 10 & 0,215 & 0,224 & 0,239 & 0,258 & 0,294 \\
\hline & 11 & 0,206 & 0,217 & 0,230 & 0,249 & 0,284 \\
\hline & 12 & 0,199 & 0,212 & 0,223 & 0,242 & 0,275 \\
\hline & 13 & 0,190 & 0,202 & 0,214 & 0,234 & 0,268 \\
\hline & 14 & 0,183 & 0,194 & 0,207 & 0,227 & 0,261 \\
\hline & 15 & 0,177 & 0,187 & 0,201 & 0,220 & 0,257 \\
\hline & 16 & 0,173 & 0,182 & 0,195 & 0,213 & 0,250 \\
\hline & 17 & 0,169 & 0,177 & 0,189 & 0,206 & 0,245 \\
\hline & 18 & 0,166 & 0,173 & 0,184 & 0,200 & 0,239 \\
\hline & 19 & 0,163 & 0,169 & 0,179 & 0,195 & 0,235 \\
\hline & 20 & 0,160 & 0,166 & 0,174 & 0,190 & 0,231 \\
\hline & 25 & 0,142 & 0,147 & 0,158 & 0,173 & 0,200 \\
\hline & 30 & 0,131 & 0,136 & 0,144 & 0,161 & 0,187 \\
\hline & $>30$ & 0,736 & 0,768 & 0,805 & 0,886 & 1,031 \\
\hline
\end{tabular}

Sumber : Conover, W.J, 1980, Practical Nonparametric Statistics second edition, New York : John Wiley \& Sons. 
Lampiran 6 : Tabel Harga Kritis Chi - Square $\left(\mathrm{X}^{2}\right)$

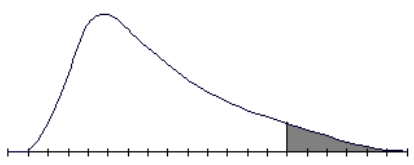

\begin{tabular}{|c|c|c|c|c|c|c|}
\hline \multirow[t]{2}{*}{$\mathrm{df}$} & \multicolumn{6}{|c|}{ Kemungkinan di bawah Ho bahwa $\mathrm{X}^{2}$ Chi - Square } \\
\hline & 0,005 & 0,010 & 0,025 & 0,050 & 0,100 & 0,200 \\
\hline 1 & 7,879 & 6,635 & 5,024 & 3,841 & 2,706 & 1,642 \\
\hline 2 & 10,597 & 9,210 & 7,378 & 5,991 & 4,605 & 3,219 \\
\hline 3 & 12,838 & 11,341 & 9,348 & 7,815 & 6,251 & 4,642 \\
\hline 4 & 14,860 & 13,277 & 11,143 & 9,488 & 7,779 & 5,989 \\
\hline 5 & 16,750 & 15,086 & 12,832 & 11,070 & 9,236 & 7,289 \\
\hline 6 & 18,548 & 16,812 & 14,449 & 12,592 & 10,645 & 8,558 \\
\hline 7 & 20,278 & 18,475 & 16,013 & 14,067 & 12,017 & 9,803 \\
\hline 8 & 21,955 & 20,090 & 17,535 & 15,507 & 13,362 & 11,030 \\
\hline 9 & 23,589 & 21,660 & 19,023 & 16,919 & 14,684 & 12,242 \\
\hline 10 & 25,188 & 23,209 & 20,483 & 18,307 & 15,987 & 13,442 \\
\hline 11 & 26,757 & 24,725 & 21,920 & 19,675 & 17,275 & 14,631 \\
\hline 12 & 28,300 & 26,217 & 23,337 & 21,026 & 18,549 & 15,812 \\
\hline 13 & 29,819 & 27,688 & 24,736 & 22,362 & 19,812 & 16,985 \\
\hline 14 & 31,319 & 29,141 & 26,119 & 23,685 & 21,064 & 18,151 \\
\hline 15 & 32,801 & 30,578 & 27,488 & 24,996 & 22,307 & 19,311 \\
\hline 16 & 34,267 & 32,000 & 28,845 & 26,296 & 23,542 & 20,465 \\
\hline 17 & 35,718 & 33,409 & 30,191 & 27,587 & 24,769 & 21,615 \\
\hline 18 & 37,156 & 34,805 & 31,526 & 28,869 & 25,989 & 22,760 \\
\hline 19 & 38,582 & 36,191 & 32,852 & 30,144 & 27,204 & 23,900 \\
\hline 20 & 39,997 & 37,566 & 34,170 & 31,410 & 28,412 & 25,038 \\
\hline 21 & 41,401 & 38,932 & 35,479 & 32,671 & 29,615 & 26,171 \\
\hline 22 & 42,796 & 40,289 & 36,781 & 33,924 & 30,813 & 27,301 \\
\hline 23 & 44,181 & 41,638 & 38,076 & 35,172 & 32,007 & 28,429 \\
\hline 24 & 45,558 & 42,980 & 39,364 & 36,415 & 33,196 & 29,553 \\
\hline 25 & 46,928 & 44,314 & 40,646 & 37,652 & 34,382 & 30,675 \\
\hline 26 & 48,290 & 45,642 & 41,923 & 38,885 & 35,563 & 31,795 \\
\hline 27 & 49,645 & 46,963 & 43,194 & 40,113 & 36,741 & 32,912 \\
\hline 28 & 50,993 & 48,278 & 44,461 & 41,337 & 37,916 & 34,027 \\
\hline 29 & 52,336 & 49,588 & 45,722 & 42,557 & 39,087 & 35,139 \\
\hline 30 & 53,672 & 50,892 & 46,979 & 43,773 & 40,256 & 36,250 \\
\hline
\end{tabular}

Sumber : Siegel, Sidney, 1956, Non Parametric Statistics For The Behavioral Sciences, New York : Mc Graw-Hill Book Company. 
Lampiran 7 : Tabel Harga Kritis F

$\mathrm{p}=0,05$ (atas)

$\mathrm{p}=0,01$ (bawah)

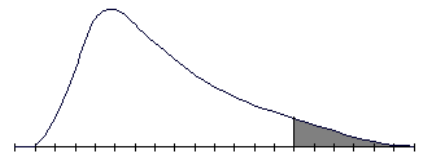

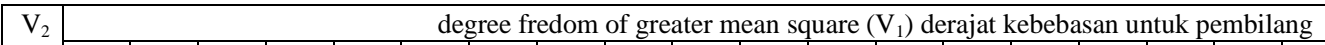

\begin{tabular}{|c|c|c|c|c|c|c|c|c|c|c|c|c|c|c|c|c|c|c|c|c|c|c|c|c|}
\hline & 1 & 2 & 3 & 4 & 5 & 6 & 7 & 8 & 9 & 10 & 11 & 12 & 14 & 16 & 20 & 24 & 30 & 40 & 50 & 75 & 100 & 200 & 500 & $\infty$ \\
\hline 1 & 161 & 200 & 216 & 225 & 230 & 234 & 237 & 239 & 241 & 242 & 243 & 244 & 245 & 246 & 248 & 249 & 250 & 251 & 252 & 253 & 253 & 254 & 254 & 254 \\
\end{tabular}

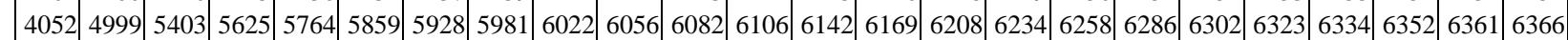

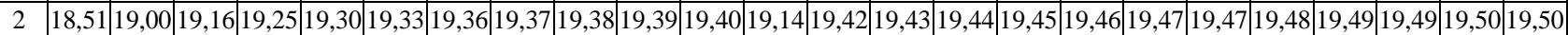

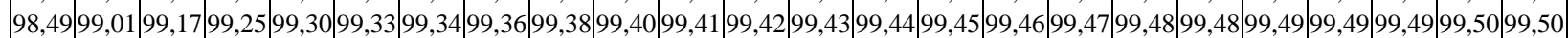

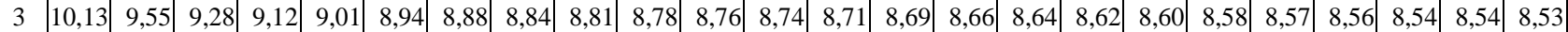

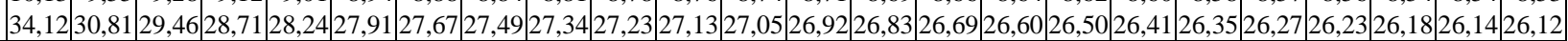

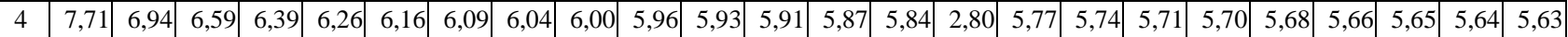

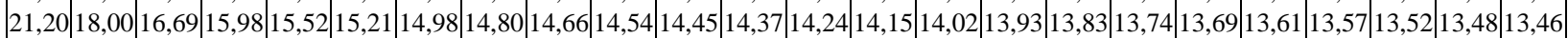

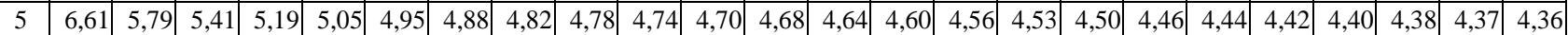

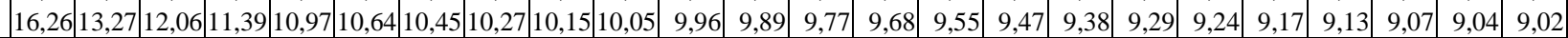

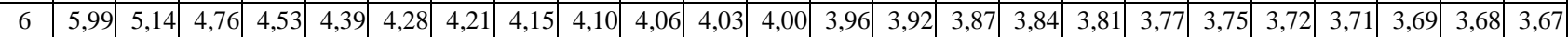
\begin{tabular}{|l|l|l|l|l|l|l|l|l|l|l|l|l|l|l|l|l|l|l|l|l|l|l|l|l|l|l|l|l|}
13,74 & 10,92 & 9,78 & 9,15 & 8,75 & 8,47 & 8,26 & 8,10 & 7,98 & 7,87 & 7,79 & 7,72 & 7,60 & 7,52 & 7,39 & 7,31 & 7,23 & 7,14 & 7,09 & 7,02 & 6,99 & 6,94 & 6,90 & 6,88 \\
\hline
\end{tabular}

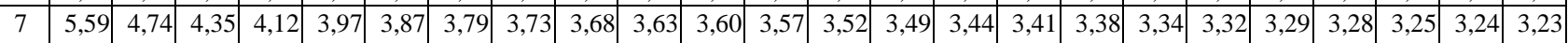
\begin{tabular}{|l|l|l|l|l|l|l|l|l|l|l|l|l|l|l|l|l|l|l|l|l|l|l|l|l|l|l|}
12,25 & 9,55 & 8,45 & 7,85 & 7,46 & 7,19 & 7,00 & 6,84 & 6,71 & 6,62 & 6,54 & 6,47 & 6,35 & 6,27 & 6,15 & 6,07 & 5,98 & 5,90 & 5,85 & 5,78 & 5,75 & 5,70 & 5,67 & 5,65 \\
\hline
\end{tabular}

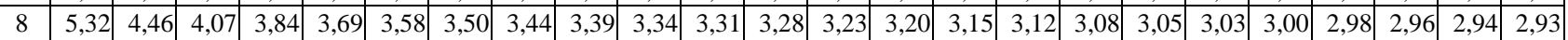

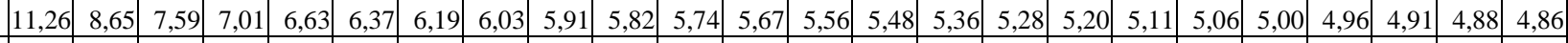

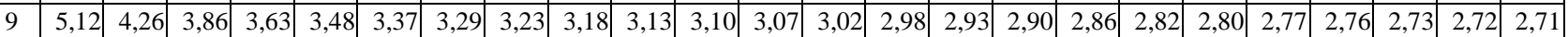

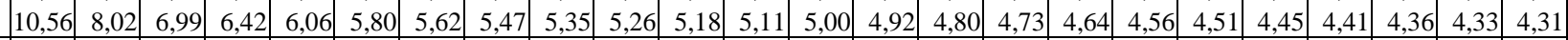

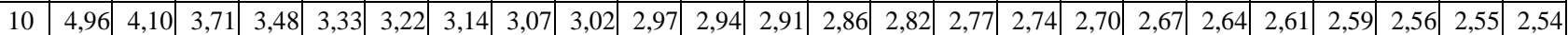

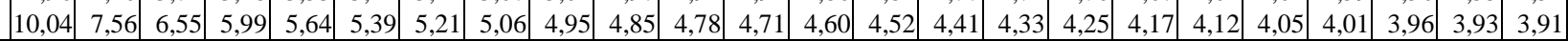

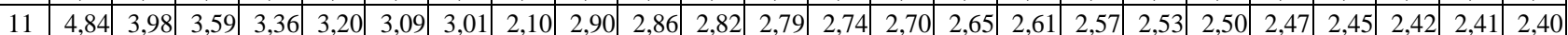

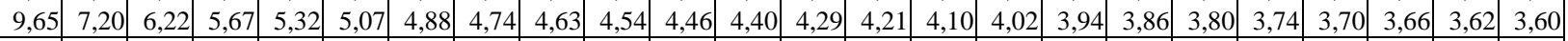

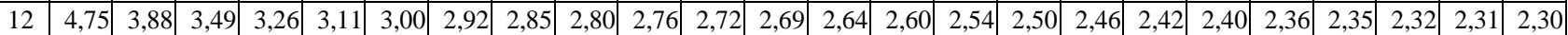

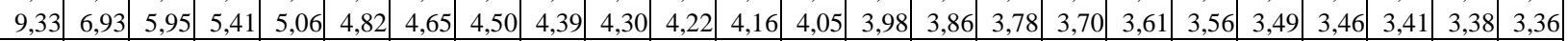

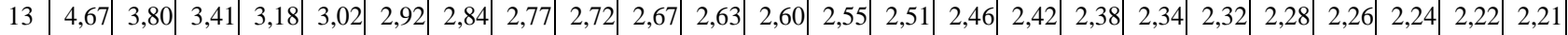

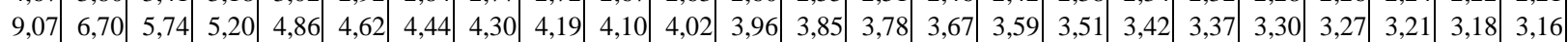

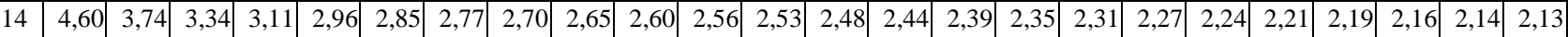

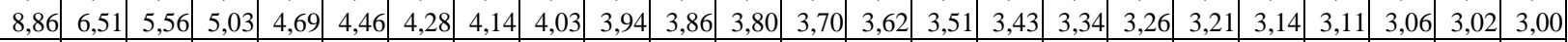

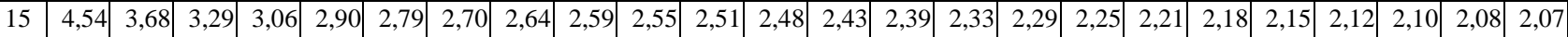
\begin{tabular}{|l|l|l|l|l|l|l|l|l|l|l|l|l|l|l|l|l|l|l|l|l|l|l|l|}
8,68 & 6,36 & 5,42 & 4,89 & 4,56 & 4,32 & 4,14 & 4,00 & 3,89 & 3,80 & 3,73 & 3,67 & 3,56 & 3,48 & 3,36 & 3,29 & 3,20 & 3,12 & 3,07 & 3,00 & 2,97 & 2,92 & 2,89 & 2,87 \\
\hline
\end{tabular}

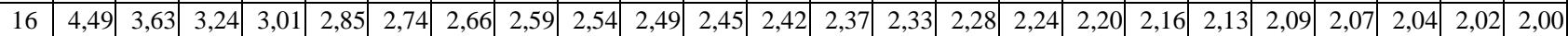

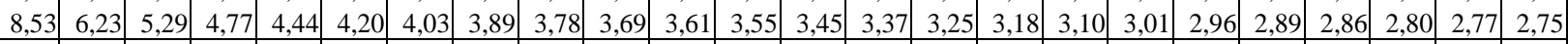

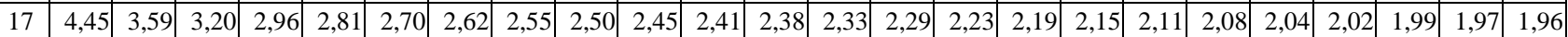

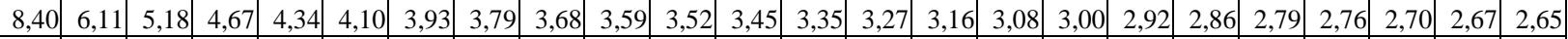

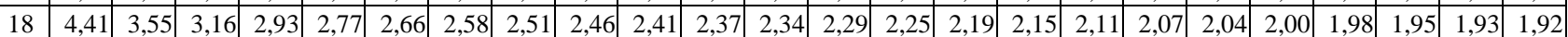

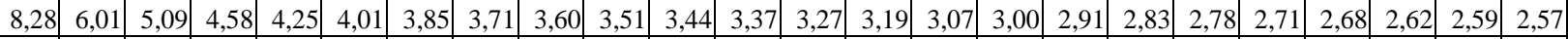

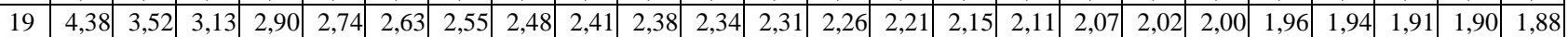

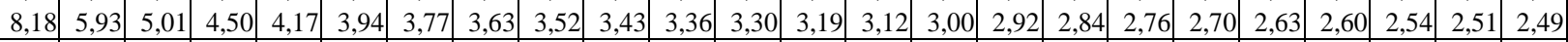

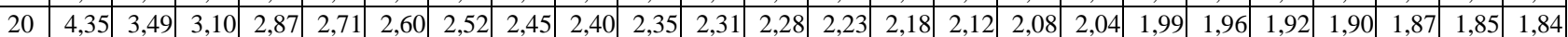

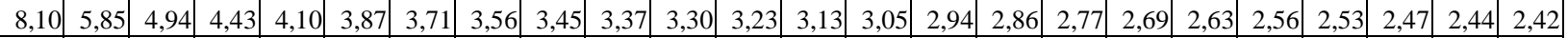

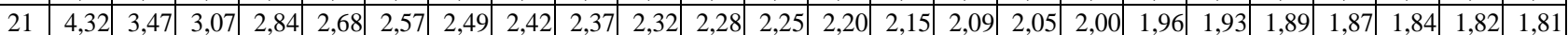

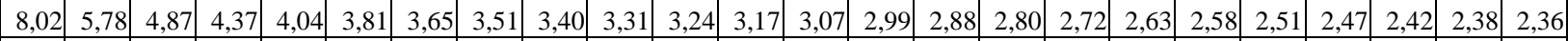

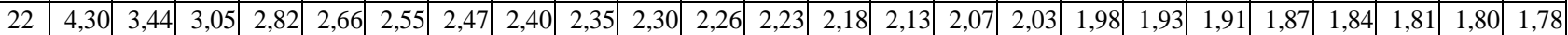

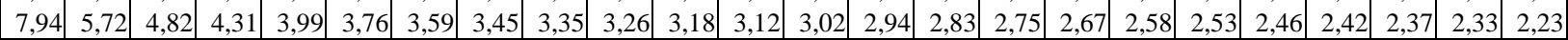

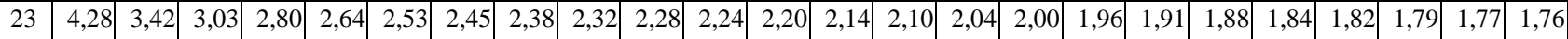
\begin{tabular}{l|l|l|l|l|l|l|l|l|l|l|l|l|l|l|l|l|l|l|l|l|l|l|l|}
7,88 & 5,66 & 4,76 & 4,26 & 3,94 & 3,71 & 3,54 & 3,41 & 3,30 & 3,21 & 3,14 & 3,07 & 2,97 & 2,89 & 2,78 & 2,70 & 2,62 & 2,53 & 2,48 & 2,41 & 2,37 & 2,32 & 2,28 & 2,26 \\
\hline
\end{tabular}

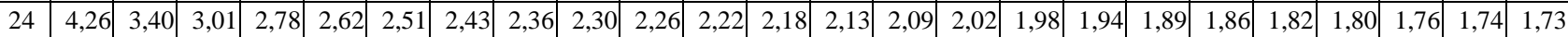
\begin{tabular}{|l|l|l|l|l|l|l|l|l|l|l|l|l|l|l|l|l|l|l|l|l|l|l|l|}
7,82 & 5,61 & 4,72 & 4,22 & 3,90 & 3,67 & 3,50 & 3,36 & 3,25 & 3,17 & 3,09 & 3,03 & 2,93 & 2,85 & 2,74 & 2,66 & 2,58 & 2,49 & 2,44 & 2,36 & 2,33 & 2,27 & 2,23 & 2,21 \\
\hline
\end{tabular}

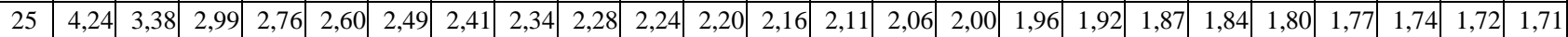

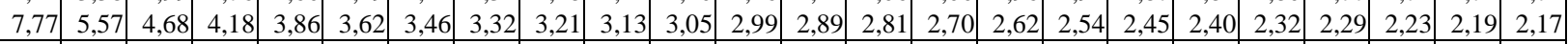

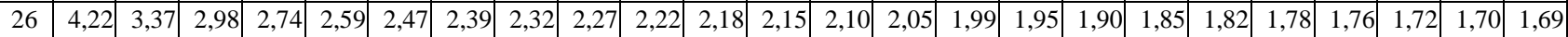

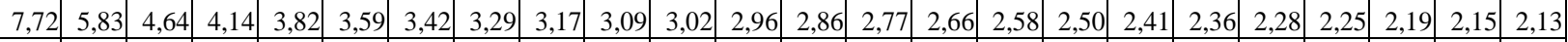

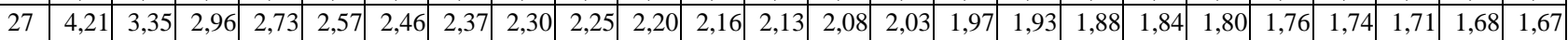

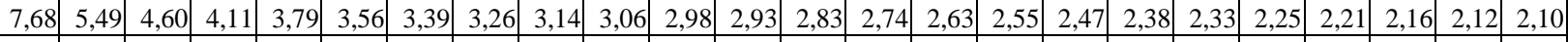

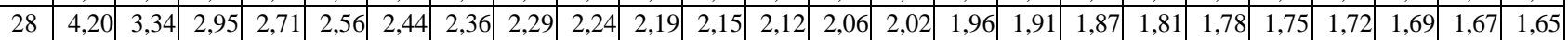

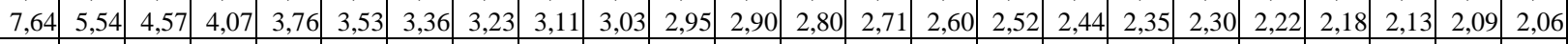

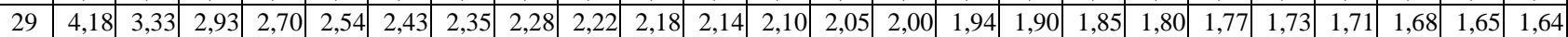

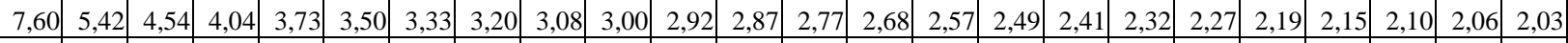

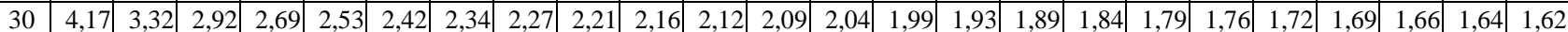
\begin{tabular}{l|l|l|l|l|l|l|l|l|l|l|l|l|l|l|l|l|l|l|l|l|l|l|l|l|}
7,56 & 5,39 & 4,51 & 4,02 & 3,70 & 3,47 & 3,30 & 3,17 & 3,06 & 2,98 & 2,90 & 2,84 & 2,74 & 2,66 & 2,55 & 2,47 & 2,38 & 2,29 & 2,24 & 2,16 & 2,13 & 2,07 & 2,03 & 2,02 \\
\hline
\end{tabular} 


\begin{tabular}{|c|c|c|c|c|c|c|c|c|c|c|c|c|c|c|c|c|c|c|c|c|c|c|c|c|}
\hline \multirow[t]{2}{*}{$\mathrm{V}_{2}$} & \multicolumn{24}{|c|}{ degree fredom of greater mean square $\left(V_{1}\right)$ derajat kebebasan untuk pembilang } \\
\hline & 1 & 2 & 3 & 4 & 5 & 6 & 7 & 8 & 9 & 10 & 11 & 12 & 14 & 16 & \begin{tabular}{|l|}
20 \\
\end{tabular} & \begin{tabular}{|l|}
24 \\
\end{tabular} & 30 & 40 & 50 & 75 & 100 & 200 & 500 & $\infty$ \\
\hline \multirow[t]{2}{*}{32} & 4,15 & 3,30 & 2,90 & 2,67 & 2,51 & 2,40 & 2,32 & & 2,19 & 2,14 & & 2,07 & 2,02 & 1,97 & 1,91 & 1,86 & 1,82 & 1,76 & 1,74 & 1,69 & 1,67 & 1,64 & 1,66 & 1,59 \\
\hline & 7,50 & 24 & 4,46 & 3,97 & 3,66 & 3,42 & 25 & 3,13 & 3,01 & 2,94 & & 2,80 & 2,70 & 2,62 & 2,51 & 2,42 & 2,34 & 2,25 & 2,20 & 2,12 & 2,08 & 2,02 & 1,98 & 1,9 \\
\hline \multirow[t]{2}{*}{34} & 4,13 & 3,28 & 2,88 & 2,65 & \begin{tabular}{|l|l|}
5,49
\end{tabular} & 2,38 & 2,30 & 23 & \begin{tabular}{|l|l}
3 & 2,17
\end{tabular} & 2,12 & 2,08 & 2,05 & 2,00 & 1,95 & 1,89 & 1,84 & 1,80 & 1,74 & 1,71 & 1,67 & 1,64 & 1,61 & 1,59 & 1,57 \\
\hline & 7,44 & 5,29 & 4,42 & 3,93 & \begin{tabular}{l|l}
3,61 \\
\end{tabular} & 3,38 & 3,21 & 08 & \begin{tabular}{l|l}
3,97 \\
\end{tabular} & 2,89 & 2,82 & 2,76 & 2,66 & 2,58 & 2,47 & 2,38 & 2,30 & 2,21 & 2,15 & 2,08 & 2,04 & 1,98 & 1,94 & 1,9 \\
\hline \multirow[t]{2}{*}{36} & 4,11 & 3,26 & 2,86 & 2,63 & \begin{tabular}{|l|l}
3,48 \\
\end{tabular} & 2,36 & 2,28 & 21 & 2,15 & 2,10 & 2,06 & 2,03 & 1,98 & 1,93 & 1,87 & 1,82 & 1,78 & 1,72 & 1,69 & 1,65 & 1,62 & 1,59 & 1,56 & 1.5 \\
\hline & 7,39 & 5,25 & 4,38 & 3,89 & 3,58 & 3,35 & 3,18 & 04 & $\begin{array}{r}+2,94 \\
\end{array}$ & 2,86 & 2,78 & 2,72 & 2,62 & 2,54 & 2,43 & 2,35 & 2,26 & 2,17 & 2,12 & 2,04 & 2,00 & 1,94 & 1,90 & 1,8 \\
\hline \multirow[t]{2}{*}{38} & 4,10 & 3,25 & 2,85 & 2,62 & \begin{tabular}{|l|l}
2,46
\end{tabular} & 2,35 & 2,26 & 19 & $\begin{array}{l}2,14 \\
\end{array}$ & 2,09 & 2,05 & 2,02 & 1,96 & 1,92 & 1,85 & 1,80 & 1,76 & 1,71 & 1,67 & 1,63 & 1,60 & 1,57 & 1,54 & 1.5 \\
\hline & 7,35 & 5,21 & 4,34 & 3,86 & \begin{tabular}{|l|l}
5,54 \\
\end{tabular} & 3,32 & 3,15 & 02 & 2,91 & 2,82 & 2,75 & 2,69 & 2,59 & 2,51 & 2,40 & 2,22 & 2,22 & 2,14 & 2,08 & 2,00 & 1,97 & 1,90 & 1,86 & , \\
\hline \multirow[t]{2}{*}{40} & 4,08 & 3,23 & 2,84 & 2,61 & 2,45 & 2,34 & 2,25 & & \begin{tabular}{|l|l|}
3 & 2,12
\end{tabular} & 2,07 & 2,04 & 00 & 1,95 & 1,90 & 1,84 & \begin{tabular}{|l|}
1,79 \\
\end{tabular} & 1,74 & 1,69 & 1,66 & 1,61 & 1,59 & 1,55 & 1,53 & 5 \\
\hline & 7,31 & 5,18 & 4,31 & 3,83 & 3,51 & 3,29 & 3,13 & 99 & 2,88 & 2,80 & 2,73 & 2,66 & 2,56 & 2,49 & 2,37 & 2,29 & 2,20 & 2,11 & 2,05 & 1,97 & 1,94 & 1,88 & 1,84 & 1, \\
\hline \multirow[t]{2}{*}{42} & 4,07 & 3,22 & 2,83 & 2 , & 2,44 & 2,32 & 2 & & & 2 , & 2,02 & 99 & 94 & 1, & 1,82 & 78 & ,73 & & 1,64 & \begin{tabular}{|l|}
1,60 \\
\end{tabular} & 1,57 & 1,54 & 1,51 & \\
\hline & 7,27 & 5,15 & 4,29 & 3,80 & 3,49 & 3,26 & 3,10 & 96 & 52, & 2,77 & 2,70 & 64 & 2 & 2,46 & 35 & 26 & 2,17 & 2,06 & 2,02 & 1,94 & 1,91 & 1,85 & 1,80 & 1, \\
\hline \multirow[t]{2}{*}{44} & 4,06 & 3,21 & 2,82 & 2 , & \begin{tabular}{|l|l|} 
& 2,43
\end{tabular} & 2,31 & 2,23 & & \begin{tabular}{|l|}
5 \\
2,
\end{tabular} & 2 , & & 98 & 92 & 88 & 81 & 76 & ,72 & 66 & 1,63 & 1,58 & ,56 & 1,52 & 1,50 & , \\
\hline & 7,24 & 5,12 & 4,26 & 3, & \begin{tabular}{|l|l}
3,46 \\
\end{tabular} & 3,24 & 3 & 94 & +2, & 2,75 & 68 & 62 & 2,52 & 2,44 & 2,32 &, 24 & 2,15 & 2,06 & 2,00 & 1,92 & 1,88 & 1,82 & 1,78 & 1,7 \\
\hline \multirow[t]{2}{*}{46} & 4,05 & 3,20 & 2,81 & 2 , & 2,42 & 2,30 & 2,22 & & + 2, & 2,04 & $2, \mathrm{e}$ & 97 & 91 & 1,87 & 1,80 & 1,75 & 1,71 & 1,65 & 1,62 & $\mid 1,57$ & 1,54 & 1,51 & 1,48 & , \\
\hline & 7,21 & 5,10 & 4,24 & 3,76 & $5 \quad 3,44$ & 3,22 & 3,05 & 92 & 2,82 & 2,73 & 2,66 & 2,60 & 2,50 & 2,42 & 2,30 & 2,22 & 2,13 & 2,04 & 1,98 & 1,90 & 1,86 & 1,80 & 1,76 & 1,7 \\
\hline \multirow[t]{2}{*}{48} & 4,04 & 3,19 & 2,80 & 2,56 & \begin{tabular}{|l|l|}
5 & 2,41
\end{tabular} & 2,30 & 2,21 & & $+2,03$ & 2,03 & 1,99 & 96 & 1,90 & 1,86 & 1,79 & 1,74 & 1,70 & 1,64 & 1,61 & 1,56 & 1,53 & 1,50 & 1,47 & 1,4 \\
\hline & 7,19 & 5,08 & 4,22 & 3,74 & $\begin{array}{l}+3,42 \\
\end{array}$ & 3,20 & 3,04 & 90 & 2,80 & 2,71 & 2,64 & 2,58 & 2,48 & 2,40 & 2,28 & 2,20 & 2,11 & 2,02 & 1,96 & 1,88 & 1,84 & 1,78 & 1,73 & 1,7 \\
\hline \multirow[t]{2}{*}{50} & 4,03 & 3,18 & 2,79 & 2,56 & \begin{tabular}{|l|l|l}
5 & 2,40
\end{tabular} & 2,29 & 2,20 & 13 & \begin{tabular}{|l|l} 
& 2,07
\end{tabular} & 2,02 & 1,98 & 95 & 1,90 & 1,85 & 1,78 & 1,74 & 1,69 & 1,63 & 1,60 & 1,55 & 1,52 & 1,48 & 1,46 & 1,4 \\
\hline & 7,17 & 5,06 & 4,20 & 3,72 & \begin{tabular}{|l|l|}
3,41 \\
\end{tabular} & 3,18 & 3,02 & 88 & 2,73 & 2,70 & 62 & 2,56 & 2,46 & 2,39 & 2,26 & 2,18 & 2,10 & 2,00 & 1,94 & 1,86 & 1,82 & 1,76 & 1,71 & 1,6 \\
\hline \multirow[t]{2}{*}{55} & 4,02 & 3,17 & 2,78 & 2,54 & $\begin{array}{l}+2,38 \\
\end{array}$ & 2,27 & 2,18 & & 2,05 & 2,00 & 1,97 & 93 & 1,88 & 1,83 & 1,76 & 1,72 & 1,67 & $1,61 \mid$ & 1,58 & 1,52 & 1,50 & 1,46 & 1,43 & 1,4 \\
\hline & 7,12 & 5,01 & 4,16 & 3,68 & \begin{tabular}{|l|l}
3,37 \\
\end{tabular} & 3,15 & 2,98 & 85 & 2, & 2,65 & 54 &, 53 & 2,43 & 2,35 & 2,23 & 2,15 & 2,06 & 1,96 & 1,90 & 1,82 & 1,78 & 1,71 & 1,66 & 1,6 \\
\hline \multirow[t]{2}{*}{60} & 4,00 & 3,15 & 2,76 & 2,52 & \begin{tabular}{|l|l}
2,37
\end{tabular} & 2,25 & 2,17 & 10 & 2,04 & 1,99 & 1.95 & 1,92 & 1,86 & 1,81 & $\mid 1,75$ & 1,70 & 1,65 & 1,59 & 1,56 & 1,50 & 1,48 & 1,44 & 1,41 & 1,3 \\
\hline & 7,03 & 4,98 & 4,13 & 3,65 & \begin{tabular}{|l|l}
5,34 \\
\end{tabular} & 3,12 & 2,95 & 82 & 2,72 & 2,63 & 56 & 2,50 & 2,40 & 2,32 & 2,20 & 2,10 & 2,03 & 1,93 & 1,87 & 1,79 & 1,74 & 1,68 & 1,63 & 1,6 \\
\hline 65 & 3,99 & 3,14 & 2,75 & 2,51 & 2,36 & 2,24 & 2,15 & & \begin{tabular}{|l|l|}
3 & 2,02
\end{tabular} & 1,98 & 1,94 & 1,90 & 1,85 & \begin{tabular}{|l|l}
1,80 \\
\end{tabular} & \begin{tabular}{|l|}
1,71 \\
\end{tabular} & \begin{tabular}{|c|}
1,68 \\
\end{tabular} & 1,63 & 1,57 & 1,54 & \begin{tabular}{|l|}
1,49 \\
\end{tabular} & 1,46 & 1,42 & 1,39 & 3 \\
\hline & 7,04 & 4,95 & 4,10 & 3,62 & 3,31 & 3,09 & 2,93 & 2 & 2, & 2,61 & 54 & 47 & 2,37 & 2,30 & 2,18 & 2,09 & 2,00 & 1,90 & 1,84 & 1,76 & 1,71 & 1,64 & 1,60 & 1,5 \\
\hline 70 & 3,98 & 3,13 & 2,74 & 2,50 & 2,35 & 2,23 & 2,14 & & \begin{tabular}{l|l}
72,01 \\
\end{tabular} & 1,97 & 193 & 89 & 1,83 & \begin{tabular}{|l|}
1,79 \\
\end{tabular} & 1,72 & \begin{tabular}{|l|}
1,67 \\
\end{tabular} & 1,62 & 1,56 & 1,53 & $\mid 1,47$ & 1,45 & 1,40 & 1,37 & 3 \\
\hline & 7,01 & 4,92 & 4,08 & 3, & 3,29 & 3,07 & 2,91 & & 7,2 & 2,59 & ] & 2,45 & 2,35 & 2,28 & 2,15 & 2,07 & 1,98 & 1,88 & 1,82 & 1,74 & 1,69 & 1,62 & 1,56 & 1,5 \\
\hline 80 & 3,96 & 3,11 & 2,72 & 2,48 & \begin{tabular}{|l|l|}
3,33 \\
\end{tabular} & 2,21 & 2,12 & & 51 , & 1,95 & 1,91 & 1,88 & 1,82 & 1,77 & 1,70 & 1,65 & 1,60 & 1,54 & 1,51 & 1,45 & 1,42 & 1,38 & 1,35 & 1,3 \\
\hline & 6,96 & 4,88 & 4,04 & 3,56 & $5 \quad 3,25$ & 3,04 & 2,87 & 74 & $\begin{array}{l}+2,64 \\
\end{array}$ & 2,55 & 48 & 2,41 & 2,32 & 2,24 & 2,11 & 2,03 & 1,94 & 1,84 & 1,78 & 1,70 & 1,65 & 1,57 & 1,52 & 1,4 \\
\hline 100 & 3,94 & 3,09 & 2,70 & 2,46 & \begin{tabular}{|l|l|}
50 \\
\end{tabular} & 2,19 & 2,10 & 03 & \begin{tabular}{|l|l}
3,97 \\
\end{tabular} & 1,92 & 1,88 & 1,85 & 1,79 & 1,75 & 1,68 & 1,63 & 1,57 & 1,51 & 1,48 & 1,42 & 1,39 & 1,34 & 1,30 & 1,2 \\
\hline &, 90 & 4,82 & 3,98 & 3, & 3,20 & 2,99 & 2,82 & 69 & 2, & 2,51 & 43 & 36 & 2,26 & 2,19 & 2,06 & 1,98 & 1,89 & 1,79 & 1,73 & 1,64 & 1,59 & 1,51 & 1,46 & 1,4 \\
\hline 125 & 3,92 & 3,07 & 2,68 & 2,44 & $\begin{array}{l}4,29 \\
\end{array}$ & 2,17 & 2,08 & 01 & 1,95 & 1,90 & 1,86 & 1,83 & 1,77 & 1,72 & 1,65 & \begin{tabular}{|l|}
1,60 \\
\end{tabular} & 1,55 & 1,49 & 1,45 & 1,39 & 1,36 & 1,31 & 1,27 & 1,2 \\
\hline & & & 3,94 & 3. & $\begin{array}{l}7,17 \\
\end{array}$ & 2,95 & 79 & & 2 & 2,47 & 40 & 33 & 2,23 & 2,15 & 2,03 & 1 & 85 & 1,75 & 1,68 & 1,59 & 1,54 & 1,46 & 1,40 & 1,3 \\
\hline 150 & 3,91 & 3,06 & 2,67 & 2,43 & \begin{tabular}{|l|l|l}
$\mid$ & 2,27
\end{tabular} & 2,10 & 2,07 & 00 & $\begin{array}{l}1,94 \\
\end{array}$ & 1,89 & 1,85 & 1,82 & 1,76 & 1,71 & 1,64 & 1,59 & 1,54 & 1,47 & 1,44 & 1,37 & 1,34 & 1,29 & 1,25 & 1,2 \\
\hline & & 4,7 & 3,91 & 3, & $\begin{array}{r}+3,14 \\
\end{array}$ & 2,92 & 2,76 & 2 & 2, & 2,44 & & 30 & 2,20 & 2,12 & 2,00 & 1,91 & 1,83 & 1,72 & 1,66 & 1,56 & 1,51 & 1,43 & 1,37 & 1,2 \\
\hline 200 & & 3,04 & 2,65 & 2,41 & 2,26 & 2,14 & 2,05 & & \begin{tabular}{l|l}
3 & 1,
\end{tabular} & 1,87 & 18 & 1,80 & 1,74 & 1,69 & 1,62 & 1,57 & 1,52 & 1,45 & 1,42 & 1,35 & 1,32 & 1,26 & 1,22 & \\
\hline & & 4,71 & 3,88 & 3, & 3,11 & 2,90 & 2,73 & & 2, & 2,41 & & 2 & 2,17 & 2,09 & 1,97 & 1,8 & 1,79 & 1,69 & 1,62 & 1,53 & 1,48 & 1,39 & 1,33 & 1, \\
\hline 400 & 3,86 & 3,02 & 2,62 & 2,39 & 2,23 & 2,12 & 2,03 & 96 & \begin{tabular}{|c|c|} 
& 1,90
\end{tabular} & 1,85 & 1,81 & 1,78 & 1,72 & 1,67 & 1,60 & $|1,54|$ & 1,49 & 1,42 & 1,38 & 1,32 & 1,28 & 1,22 & 1,16 & , \\
\hline & & 4,65 & 3,83 & 3, & $5 \quad 3,06$ & 2,85 & 2,69 & 55 & 2, & 2,37 & 29 & & 2,12 & 2,04 & 1,92 & 1,8 & 1,74 & 1,64 & 1,57 & 1,47 & 1,42 & 1,32 & 1,24 & 1 , \\
\hline 1000 & 3,85 & 3,00 & 2,61 & 2,38 & \begin{tabular}{l|l}
3,22 \\
\end{tabular} & 2,10 & 2,02 & 1,95 & \begin{tabular}{|l|l}
5 & 1,89
\end{tabular} & 1,84 & \begin{tabular}{|l|l}
1,80 \\
\end{tabular} & 1,76 & 1,70 & 1,65 & \begin{tabular}{|c|}
1,58 \\
\end{tabular} & 1,53 & 1,47 & 1,41 & 1,36 & 1,30 & 1,26 & 1,19 & 1,13 & 1,08 \\
\hline & 6,66 & 4,62 & 3,80 & 3,34 & $\begin{array}{r}+3,04 \\
\end{array}$ & 2,82 & 2,66 & 2,53 & $3 \quad 2,43$ & 2,34 & 2,26 & 2,20 & 2,09 & 2,01 & 1,89 & 1,81 & 1,71 & 1,61 & 1,54 & 1,44 & 1,38 & 1,28 & 1,19 & 1,11 \\
\hline$\infty$ & 3,84 & 2,99 & 2,60 & 2,37 & $\begin{array}{l}7,31 \\
\end{array}$ & 2,09 & 2,01 & 1,94 & $\begin{array}{l}1,88 \\
\end{array}$ & 1,83 & $1,7 \mathrm{C}$ & 1,75 & 1,69 & 1,64 & 1,57 & 1,52 & 1,46 & 1,40 & 1,35 & 1,28 & 1,24 & 1,17 & 1,11 & 1,00 \\
\hline & & 4,60 & 3,78 & 3,32 & \begin{tabular}{|l|l|}
2,02 \\
\end{tabular} & 2,80 & 2,64 & 2,51 & 2,4 & 2,32 & 2,24 & 2,18 & 2,07 & 1,99 & 1,87 & 1,79 & 1,69 & 1,59 & 1,52 & 1,41 & 1,36 & 1,25 & 1,15 & 1,0 \\
\hline
\end{tabular}

Sumber : Snedecor, George W dan Cochran, William G, 1980, Statistical Methods seventh edition, Ames Iowa USA : The Iowa State University Press 
Lampiran 8 : Tabel Nilai q

\begin{tabular}{|c|c|c|c|c|c|c|c|c|c|c|c|c|c|c|c|}
\hline \multirow{2}{*}{$\mathrm{df}$} & \multicolumn{15}{|c|}{ Jumlah Perlakuan } \\
\hline & 2 & 3 & 4 & 5 & 6 & 7 & 8 & 9 & 10 & 11 & 12 & 13 & 14 & 15 & 16 \\
\hline 1 & 26,70 & 32,80 & 37,20 & 0,50 & & 15 & 47,30 & & 50,60 & & & & 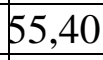 & & \\
\hline 2 & 8,28 & 9,80 & & & & & & & & & & & & 15,91 & 8,28 \\
\hline 3 & 88 & 83 & 51 & 8,04 & 8,47 & 8,35 & 9,18 & 9,46 & 9,72 & 9,95 & 10,16 & 0,35 & 10,52 & 10,69 & \\
\hline 4 & 5,00 & 76 & ,31 & 73 & 06 & ,35 & 7,60 & 7,83 & 8,03 & 8,21 & 8,37 & 8,52 & 8,67 & 8,80 & 5,00 \\
\hline 5 & 54 & 18 & 64 & 99 & 28 & 52 & 6,74 & 6,93 & 7,10 & 7,25 & 7,39 & 7,52 & 7,64 & 7,75 & 4,54 \\
\hline 6 & 4,34 & 4,90 & ,31 & ,63 & 89 & 12 & 6,32 & 6,49 & 6,65 & 6,79 & 6,92 & 7,04 & 7,14 & 7,24 & 4,34 \\
\hline 7 & 16 & 68 & & & & 80 & 5,99 & & 6,29 & 6,42 & 6,54 & 6,65 & 6,75 & 6,84 & 4,16 \\
\hline 8 & 4,04 & 4,53 & 4,89 & 17 & 5,40 & 5,60 & 5,77 & 5,92 & 6,05 & 6,18 & 6,29 & 6,39 & 6,48 & 6,57 & 4,04 \\
\hline 9 & 3,95 & & & & & & 5,60 & 5,74 & 87 & 5,98 & 6,09 & 19 & 6,28 & 5,36 & 3,95 \\
\hline 10 & 3,88 & 4,33 & 4,66 & 4,91 & 12 & 5,30 & 5,46 & 5,60 & 5,72 & 5,83 & 5,93 & 6,03 & 6,12 & 6,20 & 3,88 \\
\hline 11 & 3,82 & 26 & 58 & 82 & & ,20 & 5,35 & 5,49 & 5,61 & 5,71 & 5,81 & 5,90 & 5,98 & 6,06 & 3,82 \\
\hline 12 & 3,77 & ,20 & 51 & 75 & 95 & 12 & 27 & 5,40 & 51 & 5,61 & 5,71 & 5,80 & 5,88 & 5,95 & 3,77 \\
\hline 13 & 3,73 &, 15 & 4,46 & 4,69 & 4,88 & 5,05 & 5,19 & 5,32 & 5,43 & 5,53 & 5,63 & 5,71 & 5,79 & 5,86 & 3,73 \\
\hline 14 & 3,70 & 4 & 4 & 64 & 3 & 99 & 5,13 & 5,25 & 5,36 & 5,46 & 5,56 & 5,64 & 5,72 & 5,79 & 3,70 \\
\hline 15 & 3,67 & 4,08 & 4,37 & 4,59 & 4,78 & 4,94 & 5,08 & 5,20 & 5,31 & 5,40 & 5,49 & 5,57 & 5,65 & 5,72 & 3,67 \\
\hline 16 & 3,65 & 05 & 34 & 56 & 4,74 & 4,90 & 5,03 & 5,15 & 5,26 & 5,35 & 5,44 & 5,52 & 5,59 & 5,66 & 3,65 \\
\hline 17 & 3,62 & 4,02 & 4,31 & 4,52 & 4,70 & 4,86 & 4,99 & 5,11 & 5,21 & 5,31 & 5,39 & 5,47 & 5,55 & 5,61 & 3,62 \\
\hline 18 & 3,61 & 4,00 & 4,28 & 4,49 & 4,67 & 4,83 & 4,96 & 5,07 & 5,17 & 5,27 & 5,35 & 5,43 & 5,50 & 5,57 & 3,61 \\
\hline 19 & 3,59 & ,98 & 26 & 4,47 & 4,64 & 4,79 & 4,93 & 5,04 & 5,14 & 5,23 & 5,32 & 5,39 & 5,46 & 5,53 & 3,59 \\
\hline 20 & 3,58 & 3,96 & 4,24 & 4,45 & 4,62 & 4,77 & 4,90 & 5,01 & 5,11 & 5,20 & 5,28 & 5,36 & 5,43 & 5,50 & 3,58 \\
\hline 24 & 3,35 & 3,90 & 17 & 4,37 & 4,54 & 4,68 & 4,81 & 4,92 & 5,01 & 5,10 & 5,18 & 5,25 & 5,32 & 5,38 & 3,35 \\
\hline 30 & 3,48 & 3,84 & 4,11 & 4,30 & 4,46 & 4,60 & 4,72 & 4,83 & 4,92 & 5,00 & 5,08 & 5,15 & 5,21 & 5,27 & 3,48 \\
\hline 40 & 3,44 & 3,79 & 4,04 & 4,23 & 4,39 & 4,52 & 4,63 & 4,74 & 4,82 & 4,90 & 4,98 & 5,05 & 5,11 & 5,17 & 3,44 \\
\hline 60 & 3,40 & 3,74 & 3,98 & 4,16 & 4,31 & 4,44 & 4,55 & 4,65 & 4,73 & 4,81 & 4,88 & 4,94 & 5,00 & 5,06 & 3,40 \\
\hline 120 & 3,36 & 3,69 & 3,92 & 4,10 & 4,24 & 4,36 & 4,47 & 4,56 & 4,64 & 4,71 & 4,78 & 4,84 & 4,90 & 4,95 & 3,36 \\
\hline$\infty$ & 3,32 & 3,63 & ,86 & 4,03 & 4,17 & 4,29 & 4,39 & 4,47 & 4,55 & 4,62 & 4,68 & 4,74 & 4,80 & 4,84 & 3,32 \\
\hline
\end{tabular}

Sumber : Nasir, Moh, 1985, Metode Penelitian cetakan pertama, Jakarta : Ghalia Indonesia. 
Lampiran 9 : Tabel Angka Random

\begin{tabular}{|c|c|c|c|c|c|c|c|c|c|}
\hline 14620 & 95430 & 12951 & 81953 & 17629 & 83603 & 09137 & 26453 & 02148 & 30742 \\
\hline 09742 & 85125 & 48477 & 42783 & 70473 & 52491 & 66875 & 93650 & 91487 & 37190 \\
\hline 56919 & 17803 & 95781 & 85069 & 61594 & 85347 & 92086 & 53045 & 31847 & 36207 \\
\hline 97310 & 78209 & 51263 & 52396 & 82681 & 82611 & 70858 & 78159 & 47615 & 23721 \\
\hline 07585 & 28040 & 26939 & 64531 & 70570 & 98412 & 74070 & 83468 & 18295 & 32585 \\
\hline 25950 & 85189 & 69374 & 37904 & 06759 & 70799 & 59249 & 63461 & 75108 & 45703 \\
\hline 82973 & 16405 & 81497 & 20863 & 94072 & 83615 & 09701 & 47920 & 46857 & 31924 \\
\hline 60819 & 27364 & 59081 & 72635 & 49180 & 72537 & 46950 & 81736 & 53290 & 81736 \\
\hline 59041 & 38475 & 03615 & 84093 & 49731 & 62748 & 39206 & 47315 & 84697 & 30853 \\
\hline 74208 & 69516 & 79530 & 47649 & 53046 & 95420 & 41857 & 69420 & 79762 & 01935 \\
\hline 39412 & 03642 & 87497 & 29735 & 14308 & 46493 & 28493 & 75091 & 82753 & 15040 \\
\hline 48480 & 50075 & 11804 & 24956 & 72182 & 59649 & 16284 & 83538 & 53920 & 47192 \\
\hline 95318 & 28749 & 49512 & 35408 & 21814 & 07949 & 70949 & 50959 & 15395 & 26081 \\
\hline 77094 & 16385 & 90185 & 72635 & 86259 & 38352 & 94710 & 36853 & 94969 & 38405 \\
\hline 63158 & 49753 & 84279 & 56496 & 30618 & 23973 & 25354 & 25237 & 48544 & 20405 \\
\hline 19082 & 73645 & 09182 & 73649 & 56823 & 95208 & 49635 & 01420 & 46768 & 45362 \\
\hline 15232 & 84146 & 87729 & 65584 & 83641 & 19488 & 34739 & 57052 & 43056 & 29950 \\
\hline 94252 & 77489 & 62434 & 20965 & 20274 & 03994 & 25989 & 19609 & 74372 & 74151 \\
\hline 72020 & 18895 & 84948 & 53072 & 74573 & 19520 & 92764 & 85397 & 52095 & 18079 \\
\hline 48392 & 06359 & 47040 & 05695 & 79799 & 05342 & 54212 & 21539 & 48207 & 95920 \\
\hline 37950 & 77387 & 35495 & 48192 & 84518 & 30210 & 23805 & 27837 & 24953 & 42610 \\
\hline 09394 & 59842 & 39573 & 51630 & 78548 & 06461 & 06566 & 21752 & 78967 & 45692 \\
\hline 34800 & 28055 & 91570 & 99154 & 39603 & 76846 & 77183 & 50369 & 18501 & 68867 \\
\hline 36436 & 75946 & 85712 & 06293 & 85621 & 97764 & 53126 & 37396 & 57039 & 06096 \\
\hline 28187 & 31824 & 52265 & 80494 & 66428 & 15703 & 05792 & 53376 & 54205 & 91590 \\
\hline 13838 & 79940 & 97007 & 67511 & 87939 & 68417 & 21786 & 09822 & 67510 & 23817 \\
\hline 72201 & 08423 & 41489 & 15498 & 94911 & 79392 & 65362 & 19672 & 93682 & 84190 \\
\hline 63435 & 45192 & 62020 & 47358 & 32286 & 41659 & 31842 & 47269 & 70904 & 62972 \\
\hline 59038 & 96983 & 49218 & 57179 & 08062 & 25074 & 06374 & 96484 & 59159 & 23749 \\
\hline 62367 & 45627 & 58317 & 76928 & 50274 & 28705 & 45060 & 50903 & 66578 & 41485 \\
\hline 71254 & 81686 & 85861 & 63973 & 96086 & 89681 & 50212 & 92829 & 27698 & 62284 \\
\hline 07896 & 62924 & 35682 & 42820 & 43646 & 37385 & 37236 & 19496 & 51396 & 77975 \\
\hline 71433 & 54331 & 58437 & 03542 & 76797 & 50437 & 13576 & 72876 & 02323 & 95237 \\
\hline 54614 & 19092 & 83860 & 11351 & 32533 & 56032 & 42009 & 49745 & 14651 & 80128 \\
\hline 30176 & 71248 & 37983 & 06073 & 89096 & 43498 & 95782 & 70452 & 90804 & 12042 \\
\hline 79072 & 87795 & 23294 & 61602 & 62921 & 38385 & 69546 & 47104 & 72917 & 66273 \\
\hline 75014 & 96754 & 67151 & 82741 & 24283 & 64276 & 78438 & 70757 & 40749 & 85183 \\
\hline 37390 & 75846 & 74579 & 94806 & 54959 & 35310 & 31249 & 15101 & 95390 & 73432 \\
\hline 24524 & 32751 & 28350 & 43090 & 79672 & 94672 & 07091 & 42920 & 46046 & 38083 \\
\hline 26316 & 20378 & 16474 & 62438 & 42496 & 35191 & 49368 & 30074 & 93436 & 29425 \\
\hline 61085 & 96937 & 02520 & 86801 & 30980 & 58479 & 34924 & 25101 & 87373 & 61560 \\
\hline 45836 & 41086 & 41283 & 97460 & 51798 & 29852 & 47271 & 42480 & 94156 & 49341 \\
\hline 92403 & 19679 & 16921 & 68924 & 12521 & 31724 & 60336 & 12968 & 15971 & 07963 \\
\hline 10317 & 82592 & 65205 & 12528 & 24367 & 15817 & 12479 & 52021 & 02350 & 76394 \\
\hline 39764 & 21251 & 41749 & 43789 & 70565 & 35496 & 87172 & 76830 & 41843 & 83489 \\
\hline 83594 & 95692 & 52910 & 23202 & 93736 & 10817 & 53164 & 10724 & 27035 & 67562 \\
\hline 08087 & 01753 & 01787 & 51631 & 74978 & 79608 & 01242 & 07525 & 72656 & 80854 \\
\hline 57819 & 39689 & 32509 & 87540 & 38150 & 47873 & 14614 & 18427 & 06725 & 69326 \\
\hline 96957 & 81060 & 28587 & 60905 & 67404 & 80450 & 21082 & 16074 & 61437 & 24961 \\
\hline 48426 & 43513 & 82950 & 79838 & 45149 & 07143 & 73967 & 23723 & 06909 & 75375 \\
\hline
\end{tabular}




\begin{tabular}{|c|c|c|c|c|c|c|c|c|c|}
\hline 57856 & 87037 & 57196 & 47916 & 15960 & 13036 & 84639 & 30186 & 48347 & 40780 \\
\hline 61684 & 96598 & 28043 & 25325 & 81767 & 20792 & 39823 & 48749 & 79489 & 39329 \\
\hline 06847 & 83825 & 12858 & 18689 & 41319 & 15959 & 38030 & 80057 & 67617 & 18501 \\
\hline 40810 & 85323 & 18076 & 02821 & 94728 & 96808 & 11072 & 39823 & 63756 & 04478 \\
\hline 06461 & 45073 & 88350 & 35246 & 15851 & 16129 & 57460 & 34512 & 10243 & 47635 \\
\hline 82197 & 35028 & 96296 & 95795 & 76553 & 50223 & 37215 & 07692 & 76527 & 80764 \\
\hline 47430 & 50260 & 03643 & 72259 & 71294 & 69176 & 21753 & 58341 & 07468 & 19219 \\
\hline 25043 & 52002 & 84476 & 69512 & 95036 & 69095 & 96340 & 89713 & 06381 & 61522 \\
\hline 34718 & 11667 & 96345 & 60791 & 06387 & 54221 & 40422 & 93251 & 43456 & 89176 \\
\hline 23965 & 59698 & 09746 & 48646 & 47409 & 32406 & 80874 & 74010 & 91548 & 79394 \\
\hline 67207 & 47166 & 44917 & 94177 & 31846 & 73872 & 92835 & 12596 & 64807 & 23978 \\
\hline 08261 & 71627 & 96865 & 75380 & 42735 & 19446 & 78478 & 5681 & 07769 & 18230 \\
\hline 10289 & 93145 & 14456 & 32978 & 82587 & 64377 & 54270 & 47869 & 66444 & 68728 \\
\hline 75622 & 83203 & 14951 & 46603 & 84176 & 17564 & 53965 & 80171 & 10453 & 87972 \\
\hline 62557 & 05584 & 27879 & 08081 & 01467 & 19691 & 39814 & 66538 & 65243 & 76009 \\
\hline 51695 & 70743 & 68481 & 57937 & 62634 & 86727 & 69583 & 29308 & 51729 & 10453 \\
\hline 54839 & 69596 & 25201 & 56536 & 54517 & 86909 & 92927 & 07827 & & 52075 \\
\hline 75284 & 36241 & 59749 & 81958 & 44318 & 28067 & 67638 & 72196 & 54648 & 36886 \\
\hline 64082 & 68375 & 30361 & 32627 & 38970 & 82481 & 94725 & 66930 & 34939 & 27641 \\
\hline 94649 & 33784 & 84691 & 48334 & 74667 & 48289 & 29629 & 61248 & 47276 & 76162 \\
\hline 25261 & 28316 & 37178 & 82874 & 37083 & 73818 & 78758 & 97096 & 48508 & 26484 \\
\hline 21967 & 90859 & 05692 & 34023 & 09397 & 55027 & 39897 & 51482 & 81867 & 81783 \\
\hline 63749 & 41490 & 72232 & 71710 & 36489 & 15291 & 68579 & 83195 & 60186 & 78142 \\
\hline 63487 & 42869 & 24783 & 80895 & 78641 & 50359 & 20497 & 91381 & 72319 & 83280 \\
\hline 91729 & 08960 & 70364 & 14262 & 76861 & 06406 & 85253 & 57490 & 80497 & 54272 \\
\hline 38532 & 52361 & 41320 & 29806 & 57594 & 59360 & 50929 & 18752 & 12856 & 09587 \\
\hline 27650 & 57930 & 25216 & 67180 & 42362 & 41671 & 78178 & 09058 & 42479 & 60463 \\
\hline 68318 & 14891 & 96592 & 44278 & 80631 & 82547 & 39787 & 97394 & 98513 & 29634 \\
\hline 91423 & 83067 & 14837 & 03817 & 21850 & 39732 & 18603 & 27174 & 71319 & 82016 \\
\hline 54574 & 54648 & 29265 & 63051 & 07586 & 78418 & 48489 & 06425 & 27931 & 84965 \\
\hline 93987 & 91493 & 61816 & 09628 & 31397 & 17607 & 97095 & 47154 & 40798 & 06217 \\
\hline 59854 & 13847 & 37190 & 47369 & 39657 & 45179 & 06178 & 58918 & 37965 & 32031 \\
\hline 12636 & 51498 & 34352 & 52548 & 57125 & 24634 & 96394 & 71846 & 98148 & 12839 \\
\hline 04856 & 80651 & 35242 & 60595 & 61636 & 97294 & 56276 & 30294 & 62698 & 47548 \\
\hline 92417 & 96727 & 90734 & 84549 & 04236 & 02520 & 29057 & 22102 & 18358 & 95938 \\
\hline 95723 & 05695 & 64543 & 12870 & 17646 & 25542 & 91526 & 91395 & 46359 & 52952 \\
\hline 14398 & 47916 & 56272 & 10835 & 76054 & 67823 & 07381 & 96863 & 72547 & 29368 \\
\hline 97643 & 48258 & 46058 & 34375 & 59890 & 71663 & 82459 & 37210 & 65765 & 82546 \\
\hline 14020 & 16902 & 47286 & 27208 & 09898 & 04837 & 13967 & 24974 & 55274 & 79587 \\
\hline 38715 & 36409 & 52324 & 96537 & 99811 & 60603 & 44262 & 70562 & 82081 & 64785 \\
\hline 70051 & 31424 & 26201 & 88098 & 31019 & 36195 & 23032 & 92648 & 74724 & 68292 \\
\hline 56602 & 58040 & 48323 & 37857 & 99639 & 10700 & 98176 & 34642 & 43428 & 39068 \\
\hline 69874 & 15653 & 70998 & 02969 & 42103 & 01069 & 68736 & 52765 & 23824 & 31326 \\
\hline 35242 & 79841 & 46481 & 17365 & 84609 & 26357 & 60470 & 35212 & 51863 & 00401 \\
\hline 20364 & 89248 & 58280 & 41596 & 87712 & 97928 & 45494 & 78356 & 72100 & 32949 \\
\hline 16572 & 14877 & 42927 & 46635 & 09564 & 45334 & 63012 & 47305 & 27136 & 19428 \\
\hline & 15507 & 02159 & 21981 & 00649 & 40382 & 43087 & 34506 & 53229 & 08383 \\
\hline 04653 & 48391 & 78424 & 67282 & 46854 & 61980 & 10745 & 73924 & 12717 & 25524 \\
\hline 32077 & 87214 & 14924 & 45190 & 51808 & 30474 & 29771 & 51573 & 82713 & 69487 \\
\hline 46545 & 23074 & 80308 & 52685 & 95334 & 12428 & 50970 & 47019 & 21993 & 43350 \\
\hline
\end{tabular}

Sumber : Nasir, Moh, 1985, Metode Penelitian cetakan pertama, Jakarta : Ghalia Indonesia. 
Lampiran 10 : Tabel Besar Sampel Berdasarkan Rumus

$$
p=0,5
$$

$$
n=\frac{N \cdot Z^{2} \cdot p \cdot(1-p)}{N \cdot d^{2}+Z^{2} \cdot p \cdot(1-p)}
$$

\begin{tabular}{|c|c|c|c|c|c|c|c|c|c|c|c|c|}
\hline \multirow[t]{2}{*}{$\mathrm{N}$} & \multicolumn{3}{|c|}{$\alpha=0,10$} & \multicolumn{3}{|c|}{$\alpha=0,05$} & \multicolumn{3}{|c|}{$\alpha=0,025$} & \multicolumn{3}{|c|}{$\alpha=0,01$} \\
\hline & $\mathrm{d}=0,10$ & $\mathrm{~d}=0,05$ & $\mathrm{~d}=0,01$ & $\mathrm{~d}=0,10$ & $\mathrm{~d}=0,05$ & $\mathrm{~d}=0,01$ & $\mathrm{~d}=0,10$ & $\mathrm{~d}=0,05$ & $\mathrm{~d}=0,01$ & $\mathrm{~d}=0,10$ & $\mathrm{~d}=0,05$ & $\mathrm{~d}=0,01$ \\
\hline 5 & 4 & 5 & 5 & 5 & 5 & 5 & 5 & 5 & 5 & 5 & 5 & 5 \\
\hline 10 & 8 & 9 & 10 & 9 & 10 & 10 & 9 & 10 & 10 & 9 & 10 & 10 \\
\hline 15 & 11 & 14 & 15 & 12 & 14 & 15 & 13 & 14 & 15 & 14 & 15 & 15 \\
\hline 20 & 13 & 18 & 20 & 15 & 19 & 20 & 17 & 19 & 20 & 17 & 19 & 20 \\
\hline 25 & 1 & 22 & 25 & 18 & 23 & 25 & 20 & 23 & 25 & 21 & 24 & 25 \\
\hline 30 & 17 & 25 & 30 & 21 & 27 & 30 & 23 & 28 & 30 & 25 & 28 & 30 \\
\hline 35 & 19 & 29 & 35 & 23 & 31 & 35 & 26 & 32 & 35 & 28 & 33 & 35 \\
\hline 40 & 20 & 32 & 40 & 25 & 35 & 40 & 28 & 36 & 40 & 31 & 37 & 40 \\
\hline 45 & 21 & 35 & 45 & 27 & 39 & 45 & 31 & 40 & 45 & 34 & 42 & 45 \\
\hline 50 & 23 & 38 & 49 & 29 & 42 & 50 & 33 & 44 & 50 & 37 & 46 & 50 \\
\hline 55 & 23 & 41 & 54 & 30 & 46 & 55 & 35 & 48 & 55 & 39 & 50 & 55 \\
\hline 60 & 24 & 44 & 59 & 32 & 49 & 59 & 37 & 52 & 60 & 42 & 54 & 60 \\
\hline 65 & 25 & 47 & 64 & 33 & 52 & 64 & 39 & 56 & 65 & 44 & 58 & 65 \\
\hline 70 & 2 & 49 & 69 & 35 & 56 & 69 & 40 & 59 & 69 & 46 & 62 & 70 \\
\hline 75 & 2 & 51 & 74 & 36 & 59 & 74 & 42 & 63 & 74 & 48 & 66 & 75 \\
\hline 80 & 27 & 54 & 78 & 37 & 62 & 79 & 44 & 66 & 79 & 50 & 70 & 80 \\
\hline 85 & 28 & 56 & 83 & 38 & 65 & 84 & 45 & 70 & 84 & 52 & 73 & 84 \\
\hline 90 & 28 & 58 & 88 & 39 & 68 & 89 & 46 & 73 & 89 & 54 & 77 & 89 \\
\hline 95 & 2 & 60 & 93 & 40 & 70 & 94 & 48 & 76 & 94 & 56 & 81 & 94 \\
\hline 100 & 29 & 62 & 98 & 40 & 73 & 99 & 49 & 79 & 99 & 58 & 84 & 99 \\
\hline 110 & 30 & 66 & 107 & 42 & 78 & 108 & 51 & 86 & 109 & 61 & 91 & 109 \\
\hline 120 & 31 & 69 & 117 & 43 & 83 & 118 & 53 & 91 & 119 & 64 & 98 & 119 \\
\hline 130 & 3 & 72 & 12 & 45 & 88 & 128 & 55 & 97 & 128 & 66 & 105 & 129 \\
\hline 140 & 32 & 75 & 13 & 46 & 92 & 137 & 57 & 103 & 138 & 69 & 111 & 139 \\
\hline 150 & 32 & 78 & 145 & 47 & 97 & 147 & 59 & 108 & 148 & 71 & 118 & 148 \\
\hline 160 & 33 & 81 & 154 & 48 & 101 & 156 & 60 & 113 & 157 & 73 & 124 & 158 \\
\hline 170 & 3 & 83 & 1 & 49 & 1 & 166 & 61 & 118 & 167 & 75 & 129 & 168 \\
\hline 180 & 3 & 86 & 172 & 49 & 108 & 175 & 63 & 123 & 177 & 77 & 135 & 178 \\
\hline 190 & 34 & 88 & 182 & 50 & 112 & 185 & 64 & 127 & 186 & 79 & 141 & 187 \\
\hline 200 & 34 & 90 & 191 & 51 & 115 & 194 & 65 & 132 & 196 & 81 & 146 & 197 \\
\hline 210 & 3 & 92 & 20 & 51 & 119 & 204 & 66 & 136 & 206 & 82 & 151 & 207 \\
\hline 220 & 3 & 94 & 209 & 52 & 122 & 213 & 67 & 140 & 215 & 84 & 157 & 216 \\
\hline 230 & 35 & 96 & 218 & 53 & 125 & 222 & 68 & 144 & 225 & 85 & 162 & 226 \\
\hline 240 & 35 & 97 & 227 & 53 & 128 & 232 & 69 & 148 & 234 & 87 & 166 & 236 \\
\hline 250 & 35 & 99 & 23 & 53 & 130 & 241 & 69 & 151 & 244 & 88 & 171 & 245 \\
\hline 260 & 35 & 101 & 244 & 54 & 133 & 250 & 70 & 155 & 253 & 89 & 176 & 255 \\
\hline 270 & 36 & 102 & 253 & 54 & 136 & 260 & 71 & 159 & 263 & 90 & 180 & 265 \\
\hline 280 & 36 & 103 & 262 & 55 & 138 & 269 & 72 & 162 & 272 & 91 & 185 & 274 \\
\hline 290 & 36 & 105 & 271 & 55 & 140 & 278 & 72 & 165 & 281 & 92 & 189 & 284 \\
\hline 300 & 36 & 106 & 280 & 55 & 143 & 287 & 73 & 168 & 291 & 93 & 193 & 294 \\
\hline 310 & 36 & 107 & 288 & 56 & 145 & 296 & 73 & 172 & 300 & 94 & 197 & 303 \\
\hline 320 & 36 & 108 & 297 & 56 & 147 & 306 & 74 & 175 & 310 & 95 & 201 & 313 \\
\hline 330 & 36 & 109 & 305 & 56 & 149 & 315 & 74 & 178 & 319 & 96 & 205 & 322 \\
\hline 340 & 37 & 111 & 314 & 57 & 151 & 324 & 75 & 180 & 328 & 97 & 209 & 332 \\
\hline 350 & 37 & 112 & 322 & 57 & 153 & 333 & 75 & 183 & 338 & 98 & 213 & 341 \\
\hline
\end{tabular}




\begin{tabular}{|c|c|c|c|c|c|c|c|c|c|c|c|c|}
\hline \multirow[t]{2}{*}{$\mathrm{N}$} & \multicolumn{3}{|c|}{$\alpha=0,10$} & \multicolumn{3}{|c|}{$\alpha=0,05$} & \multicolumn{3}{|c|}{$\alpha=0,025$} & \multicolumn{3}{|c|}{$\alpha=0,01$} \\
\hline & $\mathrm{d}=0,10$ & $\mathrm{~d}=0,05$ & $\mathrm{~d}=0,01$ & $\mathrm{~d}=0,10$ & $\mathrm{~d}=0,05$ & $\mathrm{~d}=0,01$ & $\mathrm{~d}=0,10$ & $d=0,05$ & $\mathrm{~d}=0,01$ & $\mathrm{~d}=0,10$ & $\mathrm{~d}=0,05$ & $\mathrm{~d}=0,01$ \\
\hline 360 & 37 & 113 & 331 & 57 & 155 & 342 & 76 & 186 & 347 & 99 & 216 & 351 \\
\hline 370 & 37 & 114 & 339 & 57 & 157 & 351 & 76 & 188 & 356 & 99 & 220 & 360 \\
\hline 380 & 37 & 114 & 348 & 58 & 159 & 360 & 77 & 191 & 366 & 100 & 224 & 370 \\
\hline 390 & 37 & 115 & 356 & 58 & 160 & 369 & 77 & 194 & 375 & 101 & 227 & 379 \\
\hline 400 & 37 & 116 & 364 & 58 & 162 & 378 & 77 & 196 & 384 & 101 & 230 & 389 \\
\hline 410 & 37 & 117 & 373 & 58 & 164 & 387 & 78 & 198 & 393 & 102 & 234 & 398 \\
\hline 420 & 37 & 118 & 381 & 59 & 165 & 396 & 78 & 201 & 402 & 103 & 237 & 407 \\
\hline 430 & 37 & 119 & 389 & 59 & 167 & 404 & 79 & 203 & 412 & 103 & 240 & 417 \\
\hline 440 & 37 & 119 & 397 & 59 & 168 & 413 & 79 & 205 & 421 & 104 & 243 & 426 \\
\hline 450 & 38 & 120 & 405 & 59 & 170 & 422 & 79 & 207 & 430 & 104 & 246 & 436 \\
\hline 460 & 38 & 121 & 414 & 59 & 171 & 431 & 79 & 209 & 439 & 105 & 249 & 445 \\
\hline 470 & 38 & 121 & 422 & 59 & 172 & 440 & 80 & 211 & 448 & 105 & 252 & 454 \\
\hline 480 & 38 & 122 & 430 & 60 & 174 & 448 & 80 & 213 & 457 & 106 & 255 & 464 \\
\hline 490 & 38 & 123 & 438 & 60 & 175 & 457 & 80 & 215 & 466 & 106 & 258 & 473 \\
\hline 500 & 38 & 123 & 446 & 60 & 176 & 466 & 81 & 217 & 475 & 107 & 260 & 482 \\
\hline 510 & 38 & 124 & 454 & 60 & 177 & 474 & 81 & 219 & 484 & 107 & 263 & 492 \\
\hline 520 & 38 & 125 & 461 & 60 & 179 & 483 & 81 & 221 & 493 & 108 & 266 & 501 \\
\hline 530 & 38 & 125 & 469 & 60 & 180 & 492 & 81 & 223 & 502 & 108 & 268 & 510 \\
\hline 540 & 38 & 126 & 477 & 60 & 181 & 500 & 82 & 224 & 511 & 108 & 271 & 519 \\
\hline 550 & 38 & 126 & 485 & 61 & 182 & 509 & 82 & 226 & 520 & 109 & 273 & 529 \\
\hline 560 & 38 & 127 & 493 & 61 & 183 & 517 & 82 & 228 & 529 & 109 & 276 & 538 \\
\hline 570 & 38 & 127 & 500 & 61 & 184 & 526 & 82 & 229 & 538 & 110 & 278 & 547 \\
\hline 580 & 38 & 12 & 508 & 61 & 185 & 534 & 82 & 231 & 547 & 110 & 280 & 556 \\
\hline 590 & 38 & 128 & 516 & 61 & 186 & 543 & 83 & 233 & 556 & 110 & 283 & 565 \\
\hline 600 & 38 & 129 & 523 & 61 & 187 & 551 & 83 & 234 & 565 & 111 & 285 & 575 \\
\hline 610 & 38 & 129 & 531 & 61 & 188 & 560 & 83 & 236 & 574 & 111 & 287 & 584 \\
\hline 620 & 38 & 13 & 538 & 61 & 189 & 568 & 83 & 237 & 582 & 111 & 289 & 593 \\
\hline 630 & 38 & 13 & 546 & 61 & 190 & 577 & 83 & 239 & 591 & 112 & 292 & 602 \\
\hline 640 & 38 & 130 & 554 & 62 & 191 & 585 & 84 & 240 & 600 & 112 & 294 & 611 \\
\hline 650 & 39 & 131 & 561 & 62 & 192 & 593 & 84 & 241 & 609 & 112 & 296 & 620 \\
\hline 660 & 39 & 13 & 568 & 62 & 193 & 602 & 84 & 243 & 618 & 113 & 298 & 629 \\
\hline 670 & 39 & 13 & 576 & 62 & 194 & 610 & 84 & 244 & 626 & 113 & 300 & 638 \\
\hline 680 & 39 & 132 & 583 & 62 & 194 & 618 & 84 & 245 & 635 & 113 & 302 & 648 \\
\hline 690 & 39 & 132 & 591 & 62 & 195 & 626 & 84 & 247 & 644 & 113 & 304 & 657 \\
\hline 700 & 39 & 13 & 598 & 62 & 196 & 635 & 84 & 248 & 652 & 114 & 306 & 666 \\
\hline 710 & 39 & 13 & 605 & 62 & 197 & 643 & 85 & 249 & 661 & 114 & 308 & 675 \\
\hline 720 & 39 & 133 & 612 & 62 & 198 & 651 & 85 & 251 & 670 & 114 & 310 & 684 \\
\hline 730 & 39 & 134 & 620 & 62 & 198 & 659 & 85 & 252 & 678 & 114 & 311 & 693 \\
\hline 740 & 39 & 134 & 627 & 62 & 199 & 667 & 85 & 253 & 687 & 115 & 313 & 702 \\
\hline 750 & 39 & 134 & 634 & 62 & 200 & 676 & 85 & 254 & 696 & 115 & 315 & 711 \\
\hline 760 & 39 & 135 & 641 & 62 & 200 & 684 & 85 & 255 & 704 & 115 & 317 & 720 \\
\hline 770 & 39 & 135 & 648 & 63 & 201 & 692 & 85 & 256 & 713 & 115 & 318 & 729 \\
\hline 780 & 39 & 135 & 655 & 63 & 202 & 700 & 86 & 257 & 721 & 116 & 320 & 738 \\
\hline 790 & 39 & 136 & 662 & 63 & 202 & 708 & 86 & 258 & 730 & 116 & 322 & 747 \\
\hline 800 & 39 & 136 & 669 & 63 & 203 & 716 & 86 & 260 & 738 & 116 & 323 & 755 \\
\hline 810 & 39 & 136 & 676 & 63 & 204 & 724 & 86 & 261 & 747 & 116 & 325 & 764 \\
\hline 820 & 39 & 137 & 683 & 63 & 204 & 732 & 86 & 262 & 755 & 116 & 327 & 773 \\
\hline 830 & 39 & 137 & 690 & 63 & 205 & 740 & 86 & 263 & 764 & 117 & 328 & 782 \\
\hline
\end{tabular}




\begin{tabular}{|c|c|c|c|c|c|c|c|c|c|c|c|c|}
\hline \multirow[t]{2}{*}{$\mathrm{N}$} & \multicolumn{3}{|c|}{$\alpha=0,10$} & \multicolumn{3}{|c|}{$\alpha=0,05$} & \multicolumn{3}{|c|}{$\alpha=0,025$} & \multicolumn{3}{|c|}{$\alpha=0,01$} \\
\hline & $\mathrm{d}=0,10$ & $\mathrm{~d}=0,05$ & $\mathrm{~d}=0,01$ & $\mathrm{~d}=0,10$ & $\mathrm{~d}=0,05$ & $\mathrm{~d}=0,01$ & $\mathrm{~d}=0,10$ & $\mathrm{~d}=0,05$ & $\mathrm{~d}=0,01$ & $\mathrm{~d}=0,10$ & $\mathrm{~d}=0,05$ & $\mathrm{~d}=0,01$ \\
\hline 840 & 39 & 137 & 697 & 63 & 206 & 748 & 86 & 264 & 772 & 117 & 330 & 791 \\
\hline 850 & 39 & 137 & 704 & 63 & 206 & 756 & 86 & 265 & 781 & 117 & 331 & 800 \\
\hline 860 & 39 & 138 & 711 & 63 & 207 & 764 & 86 & 266 & 789 & 117 & 333 & 809 \\
\hline 870 & 39 & 138 & 718 & 63 & 207 & 771 & 86 & 266 & 798 & 117 & 334 & 818 \\
\hline 880 & 39 & 138 & 724 & 63 & 208 & 779 & 87 & 267 & 806 & 118 & 336 & 826 \\
\hline 890 & 39 & 138 & 731 & 63 & 208 & 787 & 87 & 268 & 815 & 118 & 337 & 835 \\
\hline 900 & 39 & 139 & 738 & 63 & 209 & 795 & 87 & 269 & 823 & 118 & 339 & 844 \\
\hline 910 & 39 & 139 & 745 & 63 & 210 & 803 & 87 & 270 & 831 & 118 & 340 & 853 \\
\hline 920 & 39 & 139 & 751 & 63 & 210 & 810 & 87 & 271 & 840 & 118 & 341 & 862 \\
\hline 930 & 39 & 139 & 758 & 63 & 211 & 818 & 87 & 272 & 848 & 18 & 343 & 870 \\
\hline 940 & 39 & 14 & 765 & 63 & 211 & 826 & 87 & 273 & 856 & 119 & 344 & 879 \\
\hline 950 & 39 & 140 & 771 & 64 & 212 & 834 & 87 & 274 & 864 & 119 & 345 & 888 \\
\hline 960 & 39 & 140 & 778 & 64 & 212 & 841 & 87 & 274 & 873 & 19 & 347 & 897 \\
\hline 970 & 39 & 140 & 784 & 64 & 213 & 849 & 87 & 275 & 881 & 119 & 348 & 905 \\
\hline 980 & 39 & 140 & 791 & 64 & 213 & 857 & 87 & 276 & 889 & 119 & 349 & 914 \\
\hline 990 & 39 & 141 & 797 & 64 & 214 & 864 & 88 & 277 & 897 & 119 & 351 & 923 \\
\hline 1.000 & 39 & & & 64 & 2 & 872 & 88 & 2 & 906 & 20 & 352 & 931 \\
\hline 1.100 & 39 & & & 64 & 2 & 947 & 88 & 285 & 987 & 21 & 363 & 1.018 \\
\hline 1.200 & 40 & 1 & 28 & 64 & 222 & 1.020 & 89 & 291 & 1.067 & 122 & 374 & 1.103 \\
\hline 1.300 & 40 & 14 & 987 & 65 & 225 & 1.092 & 89 & 297 & 1.145 & 123 & 383 & 1.186 \\
\hline 1.400 & 40 & 14 & 043 & 65 & 22 & 1.1 & 90 & 30 & 1. & 24 & 391 & 1.269 \\
\hline 1.500 & 40 & 148 & 1.098 & 65 & 230 & 1.229 & 90 & 306 & 1.297 & 124 & 399 & 1.351 \\
\hline 1.600 & 40 & 1 & 1.151 & 65 & 233 & 1.295 & 91 & 310 & 1.372 & 125 & 405 & 1.431 \\
\hline 1.700 & 4 & 14 & 1.2 & 65 & 235 & 1.360 & 91 & 3 & 1.444 & 126 & 411 & 1.511 \\
\hline 1.800 & 40 & 150 & 1.2. & 66 & 23 & 1.424 & 91 & 317 & 1.516 & 26 & 417 & 1.589 \\
\hline 1.900 & 40 & 15 & 1.298 & 66 & 238 & 1.48 & 91 & 320 & 1.586 & 27 & 422 & 1.667 \\
\hline 2.000 & 40 & 1 & 1.344 & 66 & 240 & 1.546 & 92 & 32 & 1.655 & 27 & 427 & 1.743 \\
\hline 2.100 & 4 & 15 & 1.388 & 66 & 241 & 1.605 & 92 & 32 & 1.7 & 27 & 431 & 1.819 \\
\hline 2.200 & 40 & 15 & 1.431 & 66 & 242 & 1.663 & 92 & 327 & 1.790 & 128 & 435 & 1.893 \\
\hline 2.300 & 40 & & 1.473 & 66 & 243 & 1.719 & 92 & 329 & 1.856 & 128 & 439 & 1.967 \\
\hline 2.400 & 40 & 1. & 1.513 & 66 & 245 & 1.774 & 92 & 33 & 1.920 & 28 & 443 & 2.039 \\
\hline 2.500 & 40 & 15 & 1.5 & 66 & 246 & 1.828 & 92 & 333 & 1.984 & 129 & 446 & 2.111 \\
\hline 2.600 & 40 & 154 & 1.590 & 66 & 246 & 1.881 & 93 & 335 & 2.046 & 129 & 449 & 2.182 \\
\hline 2.700 & 40 & & 1.627 & 66 & 247 & 1.933 & 93 & 336 & 2.108 & 129 & 452 & 2.252 \\
\hline 2.800 & 40 & 15 & 1.663 & 66 & 248 & 1.984 & 93 & 338 & 2.168 & 129 & 455 & 2.321 \\
\hline 2.900 & 40 & 15 & 1.698 & 67 & 249 & 2.034 & 93 & 339 & 2.227 & 130 & 457 & 2.389 \\
\hline 3.000 & 40 & 155 & 1.732 & 67 & 250 & 2.082 & 93 & 341 & 2.286 & 130 & 460 & 2.457 \\
\hline 3.100 & 40 & 156 & 1.765 & 67 & 250 & 2.130 & 93 & 342 & 2.344 & 130 & 462 & 2.524 \\
\hline 3.200 & 40 & 15 & 796 & 67 & 251 & 177 & 93 & 343 & 2.400 & 130 & 464 & 2.589 \\
\hline 3.300 & 40 & 156 & 1.828 & 67 & 252 & 2.222 & 93 & 344 & 2.456 & 130 & 466 & 2.655 \\
\hline 3.400 & 40 & 156 & 1.858 & 67 & 252 & 2.267 & 93 & 345 & 2.511 & 131 & 468 & 2.719 \\
\hline 3.500 & 40 & 157 & 1.887 & 67 & 253 & 2.311 & 93 & 346 & 2.565 & 131 & 470 & 2.782 \\
\hline 3.600 & 40 & & 1.916 & 67 & 253 & 2.355 & 94 & 347 & 2.6 & 131 & 472 & 2.845 \\
\hline 3.700 & 41 & 157 & 1.944 & 67 & 254 & 2.397 & 94 & 348 & 2.671 & 131 & 473 & 2.907 \\
\hline 3.800 & 41 & 157 & 1.971 & 67 & 254 & 2.439 & 94 & 349 & 2.723 & 131 & 475 & 2.969 \\
\hline 3.900 & 41 & 157 & 1.998 & 67 & 254 & 2.479 & 94 & 350 & 2.774 & 131 & 477 & 3.029 \\
\hline 4.000 & 41 & 157 & 2.024 & 67 & 255 & 2.519 & 94 & 350 & 2.824 & 131 & 478 & 3.089 \\
\hline 4.100 & 41 & 158 & 2.049 & 67 & 255 & 2.559 & 94 & 351 & 2.873 & 131 & 479 & 3.149 \\
\hline
\end{tabular}




\begin{tabular}{|c|c|c|c|c|c|c|c|c|c|c|c|c|}
\hline \multirow[t]{2}{*}{$\mathrm{N}$} & \multicolumn{3}{|c|}{$\alpha=0,10$} & \multicolumn{3}{|c|}{$\alpha=0,05$} & \multicolumn{3}{|c|}{$\alpha=0,025$} & \multicolumn{3}{|c|}{$\alpha=0,01$} \\
\hline & $\mathrm{d}=0,10$ & $\mathrm{~d}=0,05$ & $d=0,01$ & $\mathrm{~d}=0,10$ & $\mathrm{~d}=0,05$ & $\mathrm{~d}=0,01$ & $\mathrm{~d}=0,10$ & $\mathrm{~d}=0,05$ & $\mathrm{~d}=0,01$ & $\mathrm{~d}=0,10$ & $\mathrm{~d}=0,05$ & $\mathrm{~d}=0,01$ \\
\hline 4.200 & 41 & 158 & 2.074 & 67 & 256 & 2.597 & 94 & 352 & 2.922 & 131 & 481 & 3.207 \\
\hline 4.300 & 41 & 158 & 2.098 & 67 & 256 & 2.635 & 94 & 353 & 2.970 & 132 & 482 & 3.265 \\
\hline 4.400 & 41 & 158 & 2.121 & 67 & 256 & 2.672 & 94 & 353 & 3.018 & 132 & 483 & 3.323 \\
\hline 4.500 & 41 & 158 & 2.144 & 67 & 257 & 2.709 & 94 & 354 & 3.064 & 132 & 484 & 3.379 \\
\hline 4.600 & 41 & 158 & 2.167 & 67 & 257 & 2.745 & 94 & 355 & 3.110 & 132 & 486 & 3.436 \\
\hline 4.700 & 41 & 158 & 2.189 & 67 & 257 & 2.780 & 94 & 355 & 3.156 & 132 & 487 & 3.491 \\
\hline 4.800 & 41 & 158 & 2.210 & 67 & 258 & 2.815 & 94 & 356 & 3.200 & 132 & 488 & 3.546 \\
\hline 4.900 & 41 & 159 & 2.231 & 67 & 258 & 2.849 & 94 & 356 & 3.245 & 132 & 489 & 3.600 \\
\hline 5.000 & 41 & 159 & 2.252 & 67 & 258 & 2.882 & 94 & 357 & 3.288 & 132 & 490 & 3.654 \\
\hline 5.100 & 41 & 159 & 2.272 & 67 & 258 & 2.915 & 94 & 357 & 3.331 & 132 & 491 & 3.707 \\
\hline 5.200 & 41 & 159 & 2.25 & 67 & 259 & 2.948 & 94 & 358 & 3.373 & 132 & 492 & 3.760 \\
\hline 5.300 & 41 & 15 & 2.310 & 67 & 259 & 2.980 & 94 & 358 & 3.415 & 32 & 492 & 3.812 \\
\hline 5.400 & 41 & & 2.3 & 67 & 259 & 3.011 & 94 & 359 & 3.457 & & 493 & 3.863 \\
\hline 5.500 & 41 & 159 & 2.3 & 67 & 259 & 3.042 & 94 & 359 & 3.497 & 32 & 494 & 3.914 \\
\hline 5.600 & 41 & 159 & 2.366 & 67 & 260 & 3.072 & 94 & 359 & 3.537 & & 495 & 3.964 \\
\hline 5.700 & 41 & 1. & 2.3 & 67 & 260 & 3.102 & 94 & 360 & 3.577 & 33 & 496 & 4.014 \\
\hline 5.800 & 4 & & & 67 & 260 & 3.131 & 94 & 360 & 3.6 & & 496 & 4.063 \\
\hline 5.900 & 41 & & 2.4 & 67 & 260 & 3.160 & 95 & 361 & 3.655 & & 497 & 4.112 \\
\hline 6.000 & 41 & & 2.4 & 67 & 260 & 3.189 & 95 & 361 & 3.693 & & 498 & 4.161 \\
\hline 6.100 & 41 & & 2.4 & 67 & 261 & 3.217 & 95 & 361 & 3.731 & & 499 & 4.209 \\
\hline 6.200 & 41 & & & 67 & 261 & & 95 & 362 & 3.7 & & 499 & 4.256 \\
\hline 6.300 & 41 & & 2.4 & 67 & 261 & 3.272 & 95 & 362 & 3.804 & & 500 & 4.303 \\
\hline 6.400 & 41 & & 2.4 & 67 & 261 & 3.298 & 95 & 362 & 3.841 & & 500 & 4.349 \\
\hline 6.500 & 41 & & & 67 & 261 & 3.3 & 95 & 363 & 3.876 & & 501 & 4.395 \\
\hline 6.600 & 41 & & 2.5 & 67 & 261 & 3.3 & 95 & 363 & 3.912 & & 502 & 4.441 \\
\hline 6.700 & 41 & 16 & 2.5 & 67 & 262 & 3.3 & 95 & 363 & 47 & & 502 & 4.486 \\
\hline 6.800 & 41 & & & 67 & 262 & & 95 & 364 & 3.9 & & 50 & 4.530 \\
\hline 6.900 & 4 & & & 6 & 262 & 3.4 & 95 & 364 & 4.1 & & 503 & 4.574 \\
\hline 7.000 & 4 & & 2.5 & 67 & 262 & & 95 & 364 & 4.0 & & 504 & 4.618 \\
\hline 7.100 & 41 & 16 & 2.597 & 67 & 262 & 3.475 & 95 & 364 & 4.082 & 133 & 504 & 4.661 \\
\hline 7.200 & 41 & & 2.6 & 67 & 262 & 3.499 & 95 & 365 & & & 50 & 4.704 \\
\hline 7.300 & 41 & & & 6 & 262 & & 95 & 365 & & & 505 & 4.747 \\
\hline 7.400 & 41 & & 2.6 & 67 & 263 & 3.545 & 95 & 365 & 4.180 & 33 & 506 & 4.789 \\
\hline 7.500 & 41 & & 2.64 & 67 & 263 & 3.568 & 95 & 365 & 4.2 & 133 & 506 & 4.831 \\
\hline 7.600 & 41 & & 2.66 & 67 & 263 & 3.591 & 95 & 366 & & & 507 & 4.872 \\
\hline 7.700 & 4 & & 2.6 & 6 & 263 & & 95 & 366 & 4.2 & & 507 & 4.913 \\
\hline 7.800 & 41 & & 2.686 & 67 & 263 & 3.635 & 95 & 366 & 4.304 & 133 & 508 & 4.953 \\
\hline 7.900 & 41 & 161 & 2.697 & 67 & 263 & 3.656 & 95 & 366 & 4.335 & 133 & 508 & 4.993 \\
\hline 8.000 & 41 & & 2.709 & 67 & 263 & 3.678 & 95 & 367 & 4.364 & & 508 & 5.033 \\
\hline 8.100 & 41 & & 2.720 & 67 & 263 & 3.698 & 95 & 367 & 4.394 & & 509 & 5.073 \\
\hline 8.200 & 41 & 161 & 2.732 & 68 & 264 & 3.719 & 95 & 367 & 4.423 & 134 & 509 & 5.112 \\
\hline 8.300 & 41 & & 2.743 & 68 & 264 & 3.740 & 95 & 367 & 4.452 & 134 & 510 & 5.150 \\
\hline 8.400 & 41 & & 2.753 & 68 & 264 & 3.760 & 95 & 367 & 4.481 & 134 & 510 & 5.189 \\
\hline 8.500 & 41 & 161 & 2.764 & 68 & 264 & 3.780 & 95 & 368 & 4.509 & 134 & 510 & 5.227 \\
\hline 8.600 & 41 & 161 & 2.775 & 68 & 264 & 3.799 & 95 & 368 & 4.537 & 134 & 511 & 5.264 \\
\hline 8.700 & 41 & 161 & 2.785 & 68 & 264 & 3.819 & 95 & 368 & 4.565 & 134 & 511 & 5.302 \\
\hline 8.800 & 41 & 161 & 2.795 & 68 & 264 & 3.838 & 95 & 368 & 4.592 & 134 & 511 & 5.339 \\
\hline 8.900 & 41 & 161 & 2.805 & 68 & 264 & 3.857 & 95 & 368 & 4.619 & 134 & 512 & 5.375 \\
\hline
\end{tabular}




\begin{tabular}{|c|c|c|c|c|c|c|c|c|c|c|c|c|}
\hline \multirow[t]{2}{*}{$\mathrm{N}$} & \multicolumn{3}{|c|}{$\alpha=0,10$} & \multicolumn{3}{|c|}{$\alpha=0,05$} & \multicolumn{3}{|c|}{$\alpha=0,025$} & \multicolumn{3}{|c|}{$\alpha=0,01$} \\
\hline & $\mathrm{d}=0,10$ & $d=0,05$ & $\mathrm{~d}=0,01$ & $\mathrm{~d}=0,10$ & $d=0,05$ & $\mathrm{~d}=0,01$ & $\mathrm{~d}=0,10$ & $\mathrm{~d}=0,05$ & $\mathrm{~d}=0,01$ & $\mathrm{~d}=0,10$ & $\mathrm{~d}=0,05$ & $\mathrm{~d}=0,01$ \\
\hline 9.000 & 41 & 161 & 2.815 & 68 & 264 & 3.875 & 95 & 368 & 4.646 & 134 & 512 & 5.412 \\
\hline 9.100 & 41 & 161 & 2.825 & 68 & 264 & 3.894 & 95 & 369 & 4.673 & 134 & 512 & 5.448 \\
\hline 9.200 & 41 & 161 & 2.834 & 68 & 264 & 3.912 & 95 & 369 & 4.699 & 134 & 513 & 5.483 \\
\hline 9.300 & 41 & 161 & 2.844 & 68 & 265 & 3.930 & 95 & 369 & 4.725 & 134 & 513 & 5.519 \\
\hline 9.400 & 41 & 161 & 2.853 & 68 & 265 & 3.948 & 95 & 369 & 4.750 & 134 & 513 & \\
\hline 9.500 & 41 & 161 & 2.862 & 68 & 265 & 3.965 & 95 & 369 & 4.776 & 134 & 514 & 588 \\
\hline 9.600 & 41 & 161 & 2.871 & 68 & 265 & 3.983 & 95 & 369 & 4.801 & 134 & 514 & 5.623 \\
\hline 9.700 & 41 & 161 & 2.880 & 68 & 265 & 4.000 & 95 & 370 & 4.826 & 134 & 51 & 5.657 \\
\hline 9.800 & 41 & 161 & 2.889 & 68 & 265 & 4.017 & 95 & 370 & 4.851 & 134 & 51 & 5.691 \\
\hline 9.900 & 41 & 161 & 2.897 & 68 & 265 & 4.0 & 95 & 370 & 4.875 & 134 & & 5.724 \\
\hline 10.000 & 41 & 161 & 2.906 & 68 & 265 & 4.0 & 95 & 370 & 4.899 & 134 & & 5.758 \\
\hline 11.000 & 41 & 10 & 2.985 & 68 & 266 & 4.2 & 95 & 371 & 5.127 & 134 & & 6.076 \\
\hline 12.000 & 41 & & 3.054 & 68 & 266 & 4.3 & 95 & 372 & 5.335 & 134 & & 6.369 \\
\hline 13.000 & 41 & 162 & 3.115 & 68 & 267 & 4.4 & 95 & 373 & 5.523 & 134 & & 640 \\
\hline 14.000 & 41 & 162 & 3.169 & 68 & 267 & 4.5 & 95 & 374 & 5.696 & 134 & & 6.891 \\
\hline 15.000 & 41 & 16 & 3.217 & 68 & 267 & 4.6 & 95 & 375 & 5.855 & 135 & & 7.125 \\
\hline 16.000 & 4 & & 3.2 & 68 & 268 & 4.7 & 95 & 375 & & 135 & & \\
\hline 17.000 & 41 & & 3.301 & 68 & 268 & 4.8 & 96 & 376 & 6.137 & 135 & & 547 \\
\hline 18.000 & 41 & & 3.337 & 68 & 268 & 4.9 & 96 & 376 & 63 & 135 & & 7.738 \\
\hline 19.000 & 4 & & 3.370 & 68 & 268 & 5.0 & 96 & 377 & 6.379 & 135 & & 7.917 \\
\hline 20.000 & 4 & & & 68 & 269 & & 96 & 377 & & 135 & & \\
\hline 21.000 & 41 & & 3.427 & 68 & 269 & 5.140 & 96 & 377 & 6.590 & 135 & & 244 \\
\hline 22.000 & 41 & & 3.453 & 68 & 269 & 5.1 & 96 & 378 & & 135 & 5 & 8.394 \\
\hline 23.000 & 41 & & 3.477 & 68 & 269 & & 96 & 378 & & 135 & & 8.535 \\
\hline 24.000 & 4 & & 3.49 & & 269 & & 96 & 378 & & 35 & & \\
\hline 25.000 & 41 & & 3.519 & 68 & 269 & 5.3 & 96 & 378 & 6.939 & 135 & & 8.797 \\
\hline 26.000 & 4 & & 3.5 & 68 & 269 & & 96 & 379 & & 35 & & 8.917 \\
\hline 27.000 & 4 & & & 68 & 270 & & 96 & 379 & & 35 & & 032 \\
\hline 28.000 & 4 & & 3.5 & & 270 & & 96 & 379 & & 135 & 5 & \\
\hline 29.000 & 4 & & 3.589 & 68 & 270 & 5.5 & 96 & 379 & 7.215 & 135 & 5 & 9.245 \\
\hline 30.000 & 4 & & 3.604 & 68 & 270 & & 96 & 379 & & 135 & & 9.345 \\
\hline 31.000 & 4 & & & & 270 & & 96 & 379 & & 35 & & 439 \\
\hline 32.000 & 41 & & 3.63 & 68 & 270 & & 96 & 380 & 7.387 & 135 & 53 & 9.530 \\
\hline 33.000 & 41 & & 3.644 & 68 & 270 & 5.6 & 96 & 380 & 7.439 & 135 & 53 & 9.617 \\
\hline 34.000 & 4 & & 3.656 & 68 & 270 & 5.6 & 96 & 380 & 7.489 & 135 & 5 & 9.700 \\
\hline 35.000 & 4 & & 3.6 & 68 & 270 & & 96 & 380 & & 135 & 5 & 9.780 \\
\hline 36.000 & 41 & & 3.67 & 68 & 270 & 5.724 & 96 & 380 & 81 & 135 & 5 & 9.856 \\
\hline 37.000 & 41 & & 3.688 & 68 & 270 & 5.7 & 96 & 380 & 7.625 & 135 & 535 & 9.930 \\
\hline 38.000 & 41 & & 3.697 & 68 & 270 & & 96 & 380 & 7.666 & 135 & 535 & 10.000 \\
\hline 39.000 & 41 & & 3.707 & 68 & 270 & & 96 & 380 & 7.706 & 135 & 535 & 10.068 \\
\hline 40.000 & 41 & 163 & 3.716 & 68 & 270 & 5.817 & 96 & 381 & 7.745 & 135 & 536 & 10.134 \\
\hline 41.000 & 41 & & 3.724 & 68 & 270 & & 96 & 381 & 7.781 & 135 & 536 & 10.197 \\
\hline 42.000 & 4 & & 3.732 & 68 & 270 & & 96 & 381 & 7.817 & 135 & 536 & 10.258 \\
\hline 43.000 & 41 & & 3.740 & 68 & 271 & 5.876 & 96 & 381 & 7.851 & 135 & 536 & 10.316 \\
\hline 44.000 & 41 & 163 & 3.747 & 68 & 271 & 5.894 & 96 & 381 & 7.883 & 135 & 536 & 10.373 \\
\hline 45.000 & 41 & 16 & 3.754 & 68 & 271 & 5. & 96 & 381 & 7.915 & 135 & 536 & 10.427 \\
\hline & 41 & & & 68 & 271 & 5.929 & 96 & 381 & 7.945 & 135 & 537 & 10.480 \\
\hline 47.000 & 41 & 163 & 3.768 & 68 & 271 & 5.945 & 96 & 381 & 7.974 & 135 & 537 & 10.531 \\
\hline
\end{tabular}




\begin{tabular}{|c|c|c|c|c|c|c|c|c|c|c|c|c|}
\hline \multirow[t]{2}{*}{$\mathrm{N}$} & \multicolumn{3}{|c|}{$\alpha=0,10$} & \multicolumn{3}{|c|}{$\alpha=0,05$} & \multicolumn{3}{|c|}{$\alpha=0,025$} & \multicolumn{3}{|c|}{$\alpha=0,01$} \\
\hline & $\mathrm{d}=0,10$ & $\mathrm{~d}=0,05$ & $\mathrm{~d}=0,01$ & $\mathrm{~d}=0,10$ & $d=0,05$ & $\mathrm{~d}=0,01$ & $\mathrm{~d}=0,10$ & $\mathrm{~d}=0,05$ & $\mathrm{~d}=0,01$ & $\mathrm{~d}=0,10$ & $\mathrm{~d}=0,05$ & $\mathrm{~d}=0,01$ \\
\hline 48.000 & 41 & 163 & 3.774 & 68 & 271 & 5.961 & 96 & 381 & 8.003 & 135 & 537 & 10.581 \\
\hline 49.000 & 41 & 163 & 3.780 & 68 & 271 & 5.976 & 96 & 381 & 8.030 & 135 & 537 & 10.628 \\
\hline 50.000 & 41 & 163 & 3.786 & 68 & 271 & 5.991 & 96 & 381 & 8.057 & 135 & 537 & 10.675 \\
\hline 51.000 & 41 & 163 & 3.791 & 68 & 271 & 6.005 & 96 & 381 & 8.082 & 135 & 537 & 10.720 \\
\hline 52.000 & 41 & 163 & 3.797 & 68 & 271 & 6.018 & 96 & 381 & 8.107 & 135 & 537 & \\
\hline 53.000 & 41 & 163 & 3.802 & 68 & 271 & 6.032 & 96 & 381 & 8.131 & 135 & 537 & 10.805 \\
\hline 54.000 & 41 & 163 & 3.807 & 68 & 271 & 6.044 & 96 & 381 & 8.154 & 135 & 537 & 10.846 \\
\hline 55.000 & 41 & 163 & 3.812 & 68 & 271 & 6.057 & 96 & 381 & 8.176 & 135 & 538 & 10.886 \\
\hline 56.000 & 41 & 163 & 3.817 & 68 & 271 & 6.069 & 96 & 382 & 8.198 & 135 & 538 & 10.925 \\
\hline 57.000 & 41 & 163 & 3.821 & 68 & 271 & 6.080 & 96 & 382 & 8.219 & 135 & 538 & 10.962 \\
\hline 58.000 & 41 & 163 & 3.826 & 68 & 271 & 6.091 & 96 & 382 & 8.240 & 135 & 538 & 10.999 \\
\hline 59.000 & 41 & 10 & 3.830 & 68 & 271 & 6.102 & 96 & 382 & 8.260 & 135 & 538 & 11.034 \\
\hline 60.000 & 41 & & 3.834 & 68 & 271 & 6.113 & 96 & 382 & & 135 & 538 & \\
\hline 61.000 & 41 & 163 & 3.838 & 68 & 271 & 6.123 & 96 & 382 & & 135 & 538 & .102 \\
\hline 62.000 & 41 & 163 & 3.842 & 68 & 271 & 6.133 & 96 & 382 & & 135 & 538 & 11.135 \\
\hline 63.000 & 41 & & 3.846 & 68 & 27 & 6.143 & 96 & 382 & 8.334 & 135 & 538 & .167 \\
\hline 64.000 & 4 & & 3.8 & & 2 & 6.1 & 96 & & & 135 & 88 & \\
\hline 65.000 & 41 & & 3.853 & 68 & 27 & 6.161 & 96 & 382 & & 135 & 538 & .228 \\
\hline 66.000 & 41 & & 3.857 & 68 & 27 & 6.170 & 96 & 382 & & 135 & 538 & 11.257 \\
\hline 67.000 & 4 & & 3.860 & 68 & 27 & 6.179 & 96 & 38 & 8.400 & 135 & 539 & .286 \\
\hline 68.000 & 4 & & 3.8 & & & & 96 & & & 135 & 39 & \\
\hline 69.000 & 41 & & 3.866 & 68 & 27 & 6.195 & 96 & 382 & 431 & 135 & 539 & .341 \\
\hline 70.000 & 41 & & 3.870 & 68 & & 6.203 & 96 & 382 & & 135 & 539 & 11.368 \\
\hline 71.000 & 41 & & $3.8^{\prime}$ & & 2 & & 96 & 38 & & 135 & 539 & .394 \\
\hline 72.000 & 41 & & $3.8^{\prime}$ & & 2 & 6.2 & 96 & 38 & & 135 & 539 & \\
\hline 73.000 & 41 & 163 & 3.878 & 68 & 271 & 6.226 & 96 & 382 & 8.487 & 135 & 539 & 1.444 \\
\hline 74.000 & 41 & & 3.88 & & & & 96 & 382 & & 35 & 39 & .469 \\
\hline 75.000 & 4 & & 3.8 & & 27 & & 96 & & & 35 & 539 & .493 \\
\hline 76.000 & 4 & & 3.88 & & 27 & & 96 & 382 & & 135 & 539 & 516 \\
\hline 77.000 & 41 & & 3.889 & 6 & 27 & 6.253 & 96 & 382 & & 135 & 539 & 11.538 \\
\hline 78.000 & 41 & & 3.892 & & & 6.2 & 96 & 382 & & 135 & 539 & 11.561 \\
\hline 79.000 & 4 & & $3.8 \mathrm{~s}$ & & & & 96 & & & 35 & 539 & \\
\hline 80.000 & 41 & & 3.896 & & 271 & 6.273 & 96 & 382 & 8.575 & 135 & 539 & 604 \\
\hline 81.000 & 41 & & 3.899 & & 27 & 6.2 & 96 & 382 & & 135 & 539 & 11.624 \\
\hline 82.000 & 41 & & 3.901 & & 27 & 6.2 & 96 & 382 & 8.597 & 135 & 539 & 11.645 \\
\hline 83.000 & 4 & & & & 2 & & 96 & & & 136 & 539 & 11.665 \\
\hline 84.000 & 41 & 164 & 3.906 & 68 & 271 & 6.296 & 96 & 382 & 19 & 136 & 539 & 11.684 \\
\hline 85.000 & 41 & & 3.908 & 68 & 271 & 6.302 & 96 & 382 & 8.629 & 136 & 539 & 11.704 \\
\hline 86.000 & 41 & & 3.910 & & 27 & 6.307 & 96 & 382 & & 136 & 539 & 11.722 \\
\hline 87.000 & 41 & & & & 271 & 6.3 & 96 & 382 & & 136 & 540 & 11.741 \\
\hline 88.000 & 41 & 164 & 3.914 & 68 & 271 & 6.318 & 96 & 382 & 8.659 & 136 & 540 & 11.759 \\
\hline 89.000 & 41 & & 3.916 & 68 & 271 & 6.323 & 96 & 383 & 8.669 & 136 & 540 & 11.776 \\
\hline 90.000 & 4 & & & 68 & 27 & 6.328 & 96 & 383 & 578 & 136 & 540 & 11.794 \\
\hline 91.000 & 41 & & 3.920 & 68 & 271 & 6.333 & 96 & 383 & 8.687 & 136 & 540 & 11.811 \\
\hline 92.000 & 41 & 164 & 3.921 & 68 & 271 & 6.337 & 96 & 383 & 8.696 & 136 & 540 & 11.827 \\
\hline 93.000 & 41 & & 3.923 & 68 & 271 & 6.342 & 96 & 383 & 8.705 & 136 & 540 & 11.844 \\
\hline 94.000 & 41 & & & 68 & 27 & 6.347 & 96 & 383 & & 136 & 540 & 11.860 \\
\hline 95.000 & 41 & 164 & 3.927 & 68 & 271 & 6.351 & 96 & 383 & 8.722 & 136 & 540 & 11.876 \\
\hline
\end{tabular}


Lampiran 11 : Tabel Angka, Akar dan Kwadrat

\begin{tabular}{|c|c|c|c|c|c|c|c|c|c|c|c|}
\hline $\mathrm{N}$ & $\sqrt{\mathrm{N}}$ & $\mathrm{N}^{2}$ & $\mathrm{~N}$ & $\sqrt{N}$ & $\mathrm{~N}^{2}$ & $\mathrm{~N}$ & $\sqrt{\mathrm{N}}$ & $\mathrm{N}^{2}$ & $\mathrm{~N}$ & $\sqrt{\mathrm{N}}$ & $\mathrm{N}^{2}$ \\
\hline 1 & 1,000 & 1 & 51 & 7,141 & 2.601 & 101 & 10,050 & 10.201 & 151 & 12,288 & 22.801 \\
\hline 2 & 1,414 & 4 & 52 & 7,211 & 2.704 & 102 & 10,100 & 10.404 & 152 & 12,329 & 23.104 \\
\hline 3 & 1,732 & 9 & 53 & 7,280 & 2.809 & 103 & 10,149 & 10.609 & 153 & 12,369 & 23.409 \\
\hline 4 & 2,000 & 16 & 54 & 7,348 & 2.916 & 104 & 10,198 & 10.816 & 154 & 12,410 & 23.716 \\
\hline 5 & 2,236 & 25 & 55 & 7,416 & 3.025 & 105 & 10,247 & 11.025 & 155 & 12,450 & 24.025 \\
\hline 6 & 2,449 & 36 & 56 & 7,483 & 3.136 & 106 & 10,296 & 11.236 & 156 & 12,490 & 24.336 \\
\hline 7 & 2,646 & 49 & 57 & 7,550 & 3.249 & 107 & 10,344 & 11.449 & 157 & 12,530 & 24.649 \\
\hline 8 & 2,828 & 64 & 58 & 7,616 & 3.364 & 108 & 10,392 & 11.664 & 158 & 12,570 & 24.964 \\
\hline 9 & 3,000 & 81 & 59 & 7,681 & 3.481 & 109 & 10,440 & 11.881 & 159 & 12,610 & 25.281 \\
\hline 10 & 3,162 & 100 & 60 & 7,746 & 3.600 & 110 & 10,488 & 12.100 & 160 & 12,649 & 25.600 \\
\hline 11 & 3,317 & 121 & 61 & 7,810 & 3.721 & 111 & 10,536 & 12.321 & 161 & 12,689 & 25.921 \\
\hline 12 & 3,464 & 144 & 62 & 7,874 & 3.844 & 112 & 10,583 & 12.544 & 162 & 12,728 & 26.244 \\
\hline 13 & 3,606 & 169 & 63 & 7,937 & 3.969 & 113 & 10,630 & 12.769 & 163 & 12,767 & 26.569 \\
\hline 14 & 3,742 & 196 & 64 & 8,000 & 4.096 & 114 & 10,677 & 12.996 & 164 & 12,806 & 26.896 \\
\hline 15 & 3,873 & 225 & 65 & 8,062 & 4.225 & 115 & 10,724 & 13.225 & 165 & 12,845 & 27.225 \\
\hline 16 & 4,000 & 256 & 66 & 8,124 & 4.356 & 116 & 10,770 & 13.456 & 166 & 12,884 & 27.556 \\
\hline 17 & 4,123 & 289 & 67 & 8,185 & 4.489 & 117 & 10,817 & 13.689 & 167 & 12,923 & 27.889 \\
\hline 18 & 4,243 & 324 & 68 & 8,246 & 4.624 & 118 & 10,863 & 13.924 & 168 & 12,961 & 28.224 \\
\hline 19 & 4,359 & 361 & 69 & 8,307 & 4.761 & 119 & 10,909 & 14.161 & 169 & 13,000 & 28.561 \\
\hline 20 & 4,472 & 400 & 70 & 8,367 & 4.900 & 120 & 10,954 & 14.400 & 170 & 13,038 & 28.900 \\
\hline 21 & 4,583 & 441 & 71 & 8,426 & 5.041 & 121 & 11,000 & 14.641 & 171 & 13,077 & 29.241 \\
\hline 22 & 4,690 & 484 & 72 & 8,485 & 5.184 & 122 & 11,045 & 14.884 & 172 & 13,115 & 29.584 \\
\hline 23 & 4,796 & 529 & 73 & 8,544 & 5.329 & 123 & 11,091 & 15.129 & 173 & 13,153 & 29.929 \\
\hline 24 & 4,899 & 576 & 74 & 8,602 & 5.476 & 124 & 11,136 & 15.376 & 174 & 13,191 & 30.276 \\
\hline 25 & 5,000 & 625 & 75 & 8,660 & 5.625 & 125 & 11,180 & 15.625 & 175 & 13,229 & 30.625 \\
\hline 26 & 5,099 & 676 & 76 & 8,718 & 5.776 & 126 & 11,225 & 15.876 & 176 & 13,266 & 30.976 \\
\hline 27 & 5,196 & 729 & 77 & 8,775 & 5.929 & 127 & 11,269 & 16.129 & 177 & 13,304 & 31.329 \\
\hline 28 & 5,292 & 784 & 78 & 8,832 & 6.084 & 128 & 11,314 & 16.384 & 178 & 13,342 & 31.684 \\
\hline 29 & 5,385 & 841 & 79 & 8,888 & 6.241 & 129 & 11,358 & 16.641 & 179 & 13,379 & 32.041 \\
\hline 30 & 5,477 & 900 & 80 & 8,944 & 6.400 & 130 & 11,402 & 16.900 & 180 & 13,416 & 32.400 \\
\hline 31 & 5,568 & 961 & 81 & 9,000 & 6.561 & 131 & 11,446 & 17.161 & 181 & 13,454 & 32.761 \\
\hline 32 & 5,657 & 1.024 & 82 & 9,055 & 6.724 & 132 & 11,489 & 17.424 & 182 & 13,491 & 33.124 \\
\hline 33 & 5,745 & 1.089 & 83 & 9,110 & 6.889 & 133 & 11,533 & 17.689 & 183 & 13,528 & 33.489 \\
\hline 34 & 5,831 & 1.156 & 84 & 9,165 & 7.056 & 134 & 11,576 & 17.956 & 184 & 13,565 & 33.856 \\
\hline 35 & 5,916 & 1.225 & 85 & 9,220 & 7.225 & 135 & 11,619 & 18.225 & 185 & 13,601 & 34.225 \\
\hline 36 & 6,000 & 1.296 & 86 & 9,274 & 7.396 & 136 & 11,662 & 18.496 & 186 & 13,638 & 34.596 \\
\hline 37 & 6,083 & 1.369 & 87 & 9,327 & 7.569 & 137 & 11,705 & 18.769 & 187 & 13,675 & 34.969 \\
\hline 38 & 6,164 & 1.444 & 88 & 9,381 & 7.744 & 138 & 11,747 & 19.044 & 188 & 13,711 & 35.344 \\
\hline 39 & 6,245 & 1.521 & 89 & 9,434 & 7.921 & 139 & 11,790 & 19.321 & 189 & 13,748 & 35.721 \\
\hline 40 & 6,325 & 1.600 & 90 & 9,487 & 8.100 & 140 & 11,832 & 19.600 & 190 & 13,784 & 36.100 \\
\hline 41 & 6,403 & 1.681 & 91 & 9,539 & 8.281 & 141 & 11,874 & 19.881 & 191 & 13,820 & 36.481 \\
\hline 42 & 6,481 & 1.764 & 92 & 9,592 & 8.464 & 142 & 11,916 & 20.164 & 192 & 13,856 & 36.864 \\
\hline 43 & \begin{tabular}{|c|}
6,557 \\
\end{tabular} & 1.849 & 93 & 9,644 & 8.649 & 143 & 11,958 & 20.449 & 193 & 13,892 & 37.249 \\
\hline 44 & 6,633 & 1.936 & 94 & 9,695 & 8.836 & 144 & 12,000 & 20.736 & 194 & 13,928 & 37.636 \\
\hline 45 & \begin{tabular}{|c|}
6,708 \\
\end{tabular} & 2.025 & 95 & 9,747 & 9.025 & 145 & 12,042 & 21.025 & 195 & 13,964 & 38.025 \\
\hline 46 & 6,782 & 2.116 & 96 & 9,798 & 9.216 & 146 & 12,083 & 21.316 & 196 & 14,000 & 38.416 \\
\hline 47 & 6,856 & 2.209 & 97 & 9,849 & 9.409 & 147 & 12,124 & 21.609 & 197 & 14,036 & 38.809 \\
\hline 48 & 6,928 & 2.304 & 98 & 9,899 & 9.604 & 148 & 12,166 & 21.904 & 198 & 14,071 & 39.204 \\
\hline 49 & 7,000 & 2.401 & 99 & 9,950 & 9.801 & 149 & 12,207 & 22.201 & 199 & 14,107 & 39.601 \\
\hline 50 & 7,071 & 2.500 & 100 & 10,000 & 10.000 & 150 & 12,247 & 22.500 & 200 & 14,142 & 40.000 \\
\hline
\end{tabular}




\begin{tabular}{|c|c|c|c|c|c|c|c|c|c|c|c|}
\hline $\mathrm{N}$ & $\sqrt{\mathrm{N}}$ & $\mathrm{N}^{2}$ & $\mathrm{~N}$ & $\sqrt{N}$ & $\mathrm{~N}^{2}$ & $\mathrm{~N}$ & $\sqrt{N}$ & $\mathrm{~N}^{2}$ & $\mathrm{~N}$ & $\sqrt{N}$ & $\mathrm{~N}^{2}$ \\
\hline 201 & 14,177 & 40.401 & 251 & 15,843 & 63.001 & 301 & 17,349 & 90.601 & 351 & 18,735 & 123.201 \\
\hline 202 & 14,213 & 40.804 & 252 & 15,875 & 63.504 & 302 & 17,378 & 91.204 & 352 & 18,762 & 123.904 \\
\hline 203 & 14,248 & 41.209 & 253 & 15,906 & 64.009 & 303 & 17,407 & 91.809 & 353 & 18,788 & 124.609 \\
\hline 204 & 14,283 & 41.616 & 254 & 15,937 & 64.516 & 304 & 17,436 & 92.416 & 354 & 18,815 & 125.316 \\
\hline 205 & 14,318 & 42.025 & 255 & 15,969 & 65.025 & 305 & 17,464 & 93.025 & 355 & 18,841 & 126.025 \\
\hline 206 & 14,353 & 42.436 & 256 & 16,000 & 65.536 & 306 & 17,493 & 93.636 & 356 & 18,868 & 126.736 \\
\hline 207 & 14,387 & 42.849 & 257 & 16,031 & 66.049 & 307 & 17,521 & 94.249 & 357 & 18,894 & 127.449 \\
\hline 208 & 14,422 & 43.264 & 258 & 16,062 & 66.564 & 308 & 17,550 & 94.864 & 358 & 18,921 & 128.164 \\
\hline 209 & 14,457 & 43.681 & 259 & 16,093 & 67.081 & 309 & 17,578 & 95.481 & 359 & 18,947 & 128.881 \\
\hline 210 & 14,491 & 44.100 & 260 & 16,125 & 67.600 & 310 & 17,607 & 96.100 & 360 & 18,974 & 129.600 \\
\hline 211 & 14,526 & 44.521 & 261 & 16,155 & 68.121 & 311 & 17,635 & 96.721 & 361 & $\begin{array}{l}19,000 \\
\end{array}$ & 130.321 \\
\hline 212 & 14,560 & 44.944 & 262 & 16,186 & 68.644 & 312 & 17,664 & 97.344 & 362 & 19,026 & 131.044 \\
\hline 213 & 14,595 & 45.369 & 263 & 16,217 & 69.169 & 313 & 17,692 & 97.969 & 363 & 19,053 & 131.769 \\
\hline 214 & 14,629 & 45.796 & 264 & 16,248 & 69.696 & 314 & 17,720 & 98.596 & 364 & 19,079 & 132.496 \\
\hline 215 & 14,663 & 46.225 & 265 & 16,279 & 70.225 & 315 & 17,748 & 99.225 & 365 & 19,105 & 133.225 \\
\hline 216 & 14,697 & 46.656 & 266 & 16,310 & 70.756 & 316 & 17,776 & 99.856 & 366 & 19,131 & 133.956 \\
\hline 217 & 14,731 & 47.089 & 267 & 16,340 & 71.289 & 317 & 17,804 & 100.489 & 367 & 19,157 & 134.689 \\
\hline 218 & 14,765 & 47.524 & 268 & 16,371 & 71.824 & 318 & 17,833 & 101.124 & 368 & 19,183 & 135.424 \\
\hline 219 & 14,799 & 47.961 & 269 & 16,401 & 72.361 & 319 & 17,861 & 101.761 & 369 & 19,209 & 136.161 \\
\hline 220 & 14,832 & 48.400 & 270 & 16,432 & 72.900 & 320 & 17,889 & 102.400 & 370 & 19,235 & 136.900 \\
\hline 221 & 14,866 & 48.841 & 271 & 16,462 & 73.441 & 321 & 17,916 & 103.041 & 371 & 19,261 & 137.641 \\
\hline 222 & 14,900 & 49.284 & 272 & 16,492 & 73.984 & 322 & 17,944 & 103.684 & 372 & 19,287 & 138.384 \\
\hline 223 & 14,933 & 49.729 & 273 & 16,523 & 74.529 & 323 & 17,972 & 104.329 & 373 & 19,313 & 139.129 \\
\hline 224 & 14,967 & 50.176 & 274 & 16,553 & 75.076 & 324 & 18,000 & 104.976 & 374 & 19,339 & 139.876 \\
\hline 225 & 15,000 & 50.625 & 275 & 16,583 & 75.625 & 325 & 18,028 & 105.625 & 375 & 19,365 & 140.625 \\
\hline 226 & 15,033 & 51.076 & 276 & 16,613 & 76.176 & 326 & 18,055 & 106.27 & 376 & 19,391 & 141.376 \\
\hline 227 & 15,067 & 51.529 & 277 & 16,643 & 76.729 & 327 & 18,083 & 106.929 & 377 & 19,416 & 142.129 \\
\hline 228 & 15,100 & 51.984 & 278 & 16,673 & 77.284 & 328 & 18,111 & 107.584 & 378 & 19,442 & 142.884 \\
\hline 229 & 15,133 & 52.441 & 279 & 16,703 & 77.841 & 329 & 18,138 & 108.241 & 379 & 19,468 & 143.641 \\
\hline 230 & 15,166 & 52.900 & 280 & 16,733 & 78.400 & 330 & 18,166 & 108.900 & 380 & 19,494 & 144.400 \\
\hline 231 & 15,199 & 53.361 & 281 & 16,763 & 78.961 & 331 & 18,193 & 109.561 & 381 & 19,519 & 145.161 \\
\hline 232 & 15,232 & 53.824 & 282 & 16,793 & 79.524 & 332 & 18,221 & 110.224 & 382 & 19,545 & 145.924 \\
\hline 233 & 15,264 & 54.289 & 283 & 16,823 & 80.089 & 333 & 18,248 & 110.889 & 383 & 19,570 & 146.689 \\
\hline 234 & 15,297 & 54.756 & 284 & 16,852 & 80.656 & 334 & 18,276 & 111.556 & 384 & 19,596 & 147.456 \\
\hline 235 & 15,330 & 55.225 & 285 & 16,882 & 81.225 & 335 & 18,303 & 112.225 & 385 & 19,621 & 148.225 \\
\hline 236 & 15,362 & 55.696 & 286 & 16,912 & 81.796 & 336 & 18,330 & 112.896 & 386 & 19,647 & 148.996 \\
\hline 237 & 15,395 & 56.169 & 287 & 16,941 & 82.369 & 337 & 18,358 & 113.569 & 387 & 19,672 & 149.769 \\
\hline 238 & 15,427 & 56.644 & 288 & 16,971 & 82.944 & 338 & 18,385 & 114.244 & 388 & 19,698 & 150.544 \\
\hline 239 & 15,460 & 57.121 & 289 & 17,000 & 83.521 & 339 & 18,412 & 114.921 & 389 & 19,723 & 151.321 \\
\hline 240 & 15,492 & 57.600 & 290 & 17,029 & 84.100 & 340 & 18,439 & 115.600 & 390 & 19,748 & 152.100 \\
\hline 241 & 15,524 & 58.081 & 291 & 17,059 & 84.681 & 341 & 18,466 & 116.281 & 391 & 19,774 & 152.881 \\
\hline 242 & 15,556 & 58.564 & 292 & 17,088 & 85.264 & 342 & 18,493 & 116.964 & 392 & 19,799 & 153.664 \\
\hline 243 & 15,588 & 59.049 & 293 & 17,117 & 85.849 & 343 & 18,520 & 117.649 & 393 & 19,824 & 154.449 \\
\hline 244 & 15,620 & 59.536 & 294 & 17,146 & 86.436 & 344 & 18,547 & 118.336 & 394 & 19,849 & 155.236 \\
\hline 245 & 15,652 & 60.025 & 295 & 17,176 & 87.025 & 345 & 18,574 & 119.025 & 395 & 19,875 & 156.025 \\
\hline 246 & 15,684 & 60.516 & 296 & 17,205 & 87.616 & 346 & 18,601 & 119.716 & 396 & 19,900 & 156.816 \\
\hline 247 & 15,716 & 61.009 & 297 & 17,234 & 88.209 & 347 & 18,628 & 120.409 & 397 & 19,925 & 157.609 \\
\hline 248 & 15,748 & 61.504 & 298 & 17,263 & 88.804 & 348 & 18,655 & 121.104 & 398 & 19,950 & 158.404 \\
\hline 249 & 15,780 & 62.001 & 299 & 17,292 & 89.401 & 349 & 18,682 & 121.801 & 399 & 19,975 & 159.201 \\
\hline 250 & 15,811 & 62.500 & 300 & 17,321 & 90.000 & 350 & 18,708 & 122.500 & 400 & 20,000 & 160.000 \\
\hline
\end{tabular}




\begin{tabular}{|c|c|c|c|c|c|c|c|c|c|c|c|}
\hline $\mathrm{N}$ & $\sqrt{\mathrm{N}}$ & $\mathrm{N}^{2}$ & $\mathrm{~N}$ & $\sqrt{N}$ & $\mathrm{~N}^{2}$ & $\mathrm{~N}$ & $\sqrt{N}$ & $\mathrm{~N}^{2}$ & $\mathrm{~N}$ & $\sqrt{N}$ & $\mathrm{~N}^{2}$ \\
\hline 401 & 20,025 & 160.801 & 451 & 21,237 & 203.401 & 501 & 22,383 & 251.001 & 551 & 23,473 & 303.601 \\
\hline 402 & 0,050 & 161.604 & 452 & 1,260 & 204.304 & 502 & 2,405 & 252.004 & 552 & 3.495 & 304.704 \\
\hline 403 & 20,075 & 162.409 & 453 & 21,284 & 205.209 & 503 & 22,428 & 253.009 & 553 & 23,516 & 305.809 \\
\hline 404 & 20,100 & 163.216 & 454 & 21,307 & 206.116 & 504 & 22,450 & 254.016 & 554 & 23,537 & 306.916 \\
\hline 405 & 20,125 & 164.025 & 455 & 21,331 & 207.025 & 505 & 22,472 & 255.025 & 555 & 23,558 & 308.025 \\
\hline 406 & 20,149 & 164.836 & 456 & 21,354 & 207.936 & 506 & 22,494 & 256.036 & 556 & 23,580 & 309.136 \\
\hline 407 & 20,174 & 165.649 & 457 & 21,378 & 208.849 & 507 & 22,517 & $257.04 \mathrm{C}$ & 557 & 23,601 & 310.249 \\
\hline 408 & 20,199 & 166.464 & 458 & 21,401 & 209.764 & 508 & 22,539 & 258.064 & 558 & 23,622 & 311.364 \\
\hline 409 & 20,224 & 167.281 & 459 & 21,424 & 210.681 & 509 & 22,561 & 259.081 & 559 & 23,643 & 312.481 \\
\hline 410 & 20,248 & 168.100 & 460 & 21,448 & 211.600 & 510 & 22,583 & 260.100 & 560 & 23,664 & 313.600 \\
\hline 411 & 20,273 & 168.921 & 461 & 21,471 & 212.521 & 511 & 22,605 & 261.121 & 561 & 23,685 & 314.721 \\
\hline 412 & 20,298 & 169.744 & 462 & 21,494 & 213.444 & 512 & 22,627 & 262.144 & 562 & 23,707 & 315.844 \\
\hline 413 & 20,322 & 170.569 & 463 & 21,517 & 214.369 & 513 & 22,650 & 263.169 & 563 & 23,728 & 316.969 \\
\hline 414 & 20,347 & 171.396 & 464 & 21,541 & 215.296 & 514 & 22,672 & 264.19 & 564 & 23,749 & 318.096 \\
\hline 415 & 20,372 & 172.225 & 465 & 21,564 & 216.225 & 515 & 22,694 & 265.225 & 565 & 23,770 & 319.225 \\
\hline 416 & 20,396 & 173.056 & 466 & 21,587 & 217.156 & 516 & 22,716 & 266.256 & 566 & 23,791 & 320.356 \\
\hline 417 & 20,421 & 173.889 & 467 & 21,610 & 218.089 & 517 & 22,738 & 267.289 & 567 & 23,812 & 321.489 \\
\hline 418 & 20,445 & 174.724 & 468 & 21,633 & 219.024 & 518 & 22,760 & 268.324 & 568 & 23,833 & 322.624 \\
\hline 419 & 20,469 & 175.561 & 469 & 21,656 & 219.961 & 519 & 22,782 & 269.361 & 569 & 23,854 & 323.761 \\
\hline 420 & 20,494 & 176.400 & 470 & 21,679 & 220.900 & 520 & 22,804 & 270.400 & 570 & 23,875 & 324.900 \\
\hline 421 & 20,518 & 177.241 & 471 & 21,703 & 221.841 & 521 & 22,825 & 271.441 & 571 & 23,896 & 326.041 \\
\hline 422 & 20,543 & 178.084 & 472 & 21,726 & 222.784 & 522 & 22,847 & 272.484 & 572 & 23,917 & 327.184 \\
\hline 423 & 20,567 & 178.929 & 473 & 21,749 & 223.729 & 523 & 22,869 & 273.529 & 573 & 23,937 & 328.329 \\
\hline 424 & 20,591 & 179.776 & 474 & 21,772 & 224.676 & 524 & 22,891 & 274.576 & 574 & 23,958 & 329.476 \\
\hline 425 & 20,616 & 180.625 & 475 & 21,794 & 225.625 & 525 & 22,913 & 275.625 & 575 & 23,979 & 330.625 \\
\hline 426 & 20,640 & 181.476 & 476 & 21,817 & 226.576 & 526 & 22,935 & 276.67 & 576 & 24,000 & 331.776 \\
\hline 427 & 20,664 & 182.329 & 477 & 21,840 & 227.529 & 527 & 22,956 & 277.729 & 577 & 24,021 & 332.929 \\
\hline 428 & 20,688 & 183.184 & 478 & 21,863 & 228.484 & 528 & 22,978 & 278.784 & 578 & 24,042 & 334.084 \\
\hline 429 & 20,712 & 184.041 & 479 & 21,886 & 229.441 & 529 & 23,000 & 279.841 & 579 & 24,062 & 335.241 \\
\hline 430 & 20,736 & 184.900 & 480 & 21,909 & 230.400 & 530 & 23,022 & 280.900 & 580 & 24,083 & 336.400 \\
\hline 431 & 20,761 & 185.761 & 481 & 21,932 & 231.361 & 531 & 23,043 & 281.961 & 581 & 24,104 & 337.561 \\
\hline 432 & 20,785 & 186.624 & 482 & 21,954 & 232.324 & 532 & 23,065 & 283.024 & 582 & 24,125 & 338.724 \\
\hline 433 & 20,809 & 187.489 & 483 & 21,977 & 233.289 & 533 & 23,087 & 284.089 & 583 & 24,145 & 339.889 \\
\hline 434 & 20,833 & 188.356 & 484 & 22,000 & 234.256 & 534 & 23,108 & 285.156 & 584 & 24,166 & 341.056 \\
\hline 435 & 20,857 & 189.225 & 485 & 22,023 & 235.225 & 535 & 23,130 & 286.225 & 585 & 24,187 & 342.225 \\
\hline 436 & 20,881 & 190.096 & 486 & 22,045 & 236.196 & 536 & 23,152 & 287.296 & 586 & 24,207 & 343.396 \\
\hline 437 & 20,905 & 190.969 & 487 & 22,068 & 237.169 & 537 & 23,173 & 288.369 & 587 & 24,228 & 344.569 \\
\hline 438 & 20,928 & 191.844 & 488 & 22,091 & 238.144 & 538 & 23,195 & 289.444 & 588 & 24,249 & 345.744 \\
\hline 439 & 20,952 & 192.721 & 489 & 22,113 & 239.121 & 539 & 23,216 & 290.521 & 589 & 24,269 & 346.921 \\
\hline 440 & 20,976 & 193.600 & 490 & 22,136 & 240.100 & 540 & 23,238 & 291.600 & 590 & 24,290 & 348.100 \\
\hline 441 & 21,000 & 194.481 & 491 & 22,159 & 241.081 & 541 & 23,259 & 292.681 & 591 & 24,310 & 349.281 \\
\hline 442 & 21,024 & 195.364 & 492 & 22,181 & 242.064 & 542 & 23,281 & 293.764 & 592 & 24,331 & 350.464 \\
\hline 443 & 21,048 & 196.249 & 493 & 22,204 & 243.049 & 543 & 23,302 & 294.849 & 593 & 24,352 & 351.649 \\
\hline 444 & 21,071 & 197.136 & 494 & 22,226 & 244.036 & 544 & 23,324 & 295.936 & 594 & 24,372 & 352.836 \\
\hline 445 & 21,095 & 198.025 & 495 & 22,249 & 245.025 & 545 & 23,345 & 297.025 & 595 & 24,393 & 354.025 \\
\hline 446 & 21,119 & 198.916 & 496 & 22,271 & 246.016 & 546 & 23,367 & 298.116 & 596 & 24,413 & 355.216 \\
\hline 447 & 21,142 & 199.809 & 497 & 22,293 & 247.009 & 547 & 23,388 & 299.209 & 597 & 24,434 & 356.409 \\
\hline 448 & 21,166 & 200.704 & 498 & 22,316 & 248.004 & 548 & 23,409 & 300.304 & 598 & 24,454 & 357.604 \\
\hline 449 & 21,190 & 201.601 & 499 & 22,338 & 249.001 & 549 & 23,431 & 301.401 & 599 & 24,474 & 358.801 \\
\hline 450 & 21,213 & 202.500 & 500 & 22,361 & 250.000 & 550 & 23,452 & 302.500 & 600 & 24,495 & 360.000 \\
\hline
\end{tabular}




\begin{tabular}{|c|c|c|c|c|c|c|c|c|c|c|c|}
\hline $\mathbf{N}$ & $\sqrt{N}$ & $\mathrm{~N}^{2}$ & $\mathrm{~N}$ & $\sqrt{N}$ & $\mathrm{~N}^{2}$ & $\mathrm{~N}$ & $\sqrt{N}$ & $\mathrm{~N}^{2}$ & $\mathrm{~N}$ & $\sqrt{N}$ & $\mathrm{~N}^{2}$ \\
\hline 601 & 4,515 & 1.201 & 651 & 25,515 & 423.801 & 701 & 26,476 & 491.401 & 751 & 27,404 & 564.001 \\
\hline 602 & 24,536 & 362.404 & 652 & 25,534 & 425.1 & 702 & 26,495 & 492.804 & 752 & 7,423 & 565.5 \\
\hline 603 & 24,556 & 363.609 & 653 & 25,554 & 426.409 & 703 & 26,514 & 494.209 & 753 & 27,441 & 567.009 \\
\hline 604 & 24,576 & 364.816 & 654 & 25,573 & 427.716 & 704 & 26,533 & 495.616 & 754 & 27,459 & 568.516 \\
\hline 605 & 24,597 & 366.025 & 655 & 25,593 & 429.025 & 705 & 26,552 & 497.025 & 755 & 27,477 & 570.025 \\
\hline 606 & 24,617 & 367.236 & 656 & 25,612 & 430.336 & 706 & 26,571 & 498.436 & 756 & 7,495 & 571.536 \\
\hline 607 & 24,637 & 368.449 & 657 & 25,632 & 431.649 & 707 & 26,589 & 499.849 & 757 & 7,514 & 573.049 \\
\hline 608 & 24,658 & 369.664 & 658 & 25,652 & 432.964 & 708 & 26,608 & 501.264 & 758 & 27,532 & 574.564 \\
\hline 609 & 24,678 & 370.881 & 659 & 25,671 & 434.281 & 709 & 26,627 & 502.681 & 759 & 27,550 & 576.081 \\
\hline 610 & 24,698 & 372.100 & 660 & 25,690 & 435.600 & 710 & 26,646 & 504.100 & 760 & 27,568 & 577.600 \\
\hline 611 & 24,718 & 373.321 & 661 & 25,710 & 436.921 & 711 & 26,665 & 505.521 & 761 & 27,586 & 579.121 \\
\hline 612 & 24,739 & 374.544 & 662 & 25,729 & 438.244 & 712 & 26,683 & 506.944 & 762 & 27,604 & 580.644 \\
\hline 613 & 24,759 & 375.769 & 663 & 25,749 & 439.569 & 713 & 26,702 & 508.369 & 763 & 27,622 & 582.169 \\
\hline 614 & 24,779 & 376.996 & 664 & 25,768 & 440.896 & 714 & 26,721 & 509.796 & 764 & 27,641 & 583.696 \\
\hline 615 & 24,799 & 378.225 & 665 & 25,788 & 442.225 & 715 & 26,739 & 511.225 & 765 & 27,659 & 585.225 \\
\hline 616 & 24,819 & 379.456 & 666 & 25,807 & 443.556 & 716 & 26,758 & 512.656 & 766 & 27,677 & 586.756 \\
\hline 617 & 24,839 & 380.689 & 667 & 25,826 & 444.889 & 717 & 26,777 & 514.089 & 767 & 27,695 & 588.289 \\
\hline 618 & 24,860 & 381.924 & 668 & 25,846 & 446.224 & 718 & 26,796 & 515.524 & 768 & 27,713 & 589.824 \\
\hline 619 & 24,880 & 383.161 & 669 & 25,865 & 447.561 & 719 & 26,814 & 516.961 & 769 & 27,731 & 591.361 \\
\hline 620 & 24,900 & 384.400 & 670 & 25,884 & 448.900 & 720 & 26,833 & 518.400 & 770 & 27,749 & 592.900 \\
\hline 621 & 24,920 & 385.641 & 671 & 25,904 & 450.241 & 721 & 26,851 & 519.841 & 771 & 27,767 & 594.441 \\
\hline 622 & 24,940 & 386.884 & 672 & 25,923 & 451.584 & 722 & 26,870 & 521.284 & 772 & 27,785 & 595.984 \\
\hline 623 & 24,960 & 388.129 & 673 & 25,942 & 452.929 & 723 & 26,889 & 522.729 & 773 & 27,803 & 597.529 \\
\hline 624 & 24,980 & 389.376 & 674 & 25,962 & 454.276 & 724 & 26,907 & 524.176 & 774 & 27,821 & 599.076 \\
\hline 625 & 25,000 & 390.625 & 675 & 25,981 & 455.625 & 725 & 26,926 & 525.625 & 775 & 27,83 & 600.625 \\
\hline 626 & 5,020 & 391.876 & 676 & 26,000 & 456.976 & 726 & 26,944 & 527.076 & 776 & 27,85 & 602.176 \\
\hline 627 & 25,040 & 393.129 & 677 & 26,019 & 458.329 & 727 & 26,963 & 528.529 & 777 & 27,875 & 603.729 \\
\hline 628 & 25,060 & 394.384 & 678 & 26,038 & 459.684 & 728 & 26,981 & 529.984 & 778 & 27, & 605.284 \\
\hline 629 & 25,080 & 395.641 & 679 & 26,058 & 461.041 & 729 & 27,000 & 531.441 & 779 & 27,911 & 606.841 \\
\hline 630 & 25,100 & 396.900 & 680 & 26,077 & 462.400 & 730 & 27,019 & 532.900 & 780 & 27,928 & 608.400 \\
\hline 631 & 25,120 & 398.161 & 681 & 26,096 & 463.761 & 731 & 27,037 & 534.361 & 781 & 27,946 & 609.961 \\
\hline 632 & 25,140 & 399.424 & 682 & 26,115 & 465.124 & 732 & 27,055 & 535.824 & 782 & 27,964 & 611.524 \\
\hline 633 & 25,159 & 400.689 & 683 & 26,134 & 466.489 & 733 & 27,074 & 537.289 & 783 & 27,982 & 613.089 \\
\hline 634 & 5,179 & 401.956 & 684 & 26,153 & 467.856 & 734 & 27,092 & 538.756 & 784 & 28,000 & 614.656 \\
\hline 635 & 25,199 & 403.225 & 685 & 6,173 & 469.225 & 735 & 27,111 & 540.225 & 785 & & 616.225 \\
\hline 636 & 5,219 & 404.496 & 686 & 26,192 & 470.596 & 736 & 27,129 & 541.696 & 786 & 28,036 & 617.796 \\
\hline 637 & 25,239 & 405.769 & 687 & 26,211 & 471.969 & 737 & 27,148 & 543.169 & 787 & 28,054 & 619.369 \\
\hline 638 & 25,259 & 407.044 & 688 & 26,230 & 473.344 & 738 & 27,166 & 544.644 & 788 & 28,071 & 620.944 \\
\hline 639 & 5,278 & 408.321 & 689 & 26,249 & 474.721 & 739 & 27,185 & 546.121 & 789 & 28,089 & 622.521 \\
\hline 640 & 5,298 & 409.600 & 690 & 26,268 & 476.100 & 740 & 27,203 & 547.600 & 790 & & 624.100 \\
\hline 641 & 25,318 & 410.881 & 691 & 26,287 & 477.481 & 741 & 27,221 & 549.081 & 791 & 28,125 & 625.681 \\
\hline 642 & 25,338 & 412.164 & 692 & 26,306 & 478.864 & 742 & 27,240 & 550.564 & 792 & 28,142 & 627.264 \\
\hline 643 & 25,357 & 413.449 & 693 & 26,325 & 480.249 & 743 & 27,258 & 552.049 & 793 & 28,160 & 628.849 \\
\hline 644 & 25,377 & 414.736 & 694 & 26,344 & 481.636 & 744 & 27,276 & 553.536 & 794 & 28,178 & 630.436 \\
\hline 645 & 25,397 & 416.025 & 695 & 26,363 & 483.025 & 745 & 27,295 & 555.025 & 795 & 28,196 & 632.025 \\
\hline 646 & 25,417 & 417.316 & 696 & 26,382 & 484.416 & 746 & 27,313 & 556.516 & 796 & 28,213 & 633.616 \\
\hline 647 & 25,436 & 418.609 & 697 & 26,401 & 485.809 & 747 & 27,331 & 558.009 & 797 & 28,231 & 635.209 \\
\hline 648 & 25,456 & 419.904 & 698 & 26,420 & 487.204 & 748 & 27,350 & 559.504 & 798 & 28,249 & 636.804 \\
\hline 649 & 25,475 & 421.201 & 699 & 26,439 & 488.601 & 749 & 27,368 & 561.001 & 799 & 28,267 & 638.401 \\
\hline 650 & 25,495 & 422.500 & 700 & 26,458 & 490.000 & 750 & 27,386 & 562.500 & 800 & 28,284 & 640.000 \\
\hline
\end{tabular}




\begin{tabular}{|c|c|c|c|c|c|c|c|c|c|c|c|}
\hline $\mathrm{N}$ & $\sqrt{\mathrm{N}}$ & $\mathrm{N}^{2}$ & $\mathrm{~N}$ & $\sqrt{\mathrm{N}}$ & $\mathrm{N}^{2}$ & $\mathrm{~N}$ & $\sqrt{\mathrm{N}}$ & $\mathrm{N}^{2}$ & $\mathrm{~N}$ & $\sqrt{\mathrm{N}}$ & $\mathrm{N}^{2}$ \\
\hline 801 & 28,302 & 641.601 & 851 & 29,172 & 724.201 & 901 & 30,017 & 811.801 & 951 & 30.838 & 904.401 \\
\hline 802 & 320 & 204 & 852 & & 25.904 & 302 & 033 & 3.604 & 952 & & 906.304 \\
\hline 803 & 8,337 & 644.809 & 853 & 29,206 & 727.609 & 903 & 30,050 & 15.409 & 953 & 0,871 & 908.209 \\
\hline 804 & 28,355 & 646.416 & 854 & 29,223 & 729.316 & 904 & 30,067 & 817.216 & 954 & 30,887 & 910.116 \\
\hline 805 & 28,373 & 648.025 & 855 & 29,240 & 731.025 & 905 & 30,083 & 819.025 & 955 & 30,903 & 912.025 \\
\hline 806 & 28,390 & 649.636 & 856 & 29,257 & 732.736 & 906 & 30,100 & 820.836 & 956 & 30,919 & 913.936 \\
\hline 807 & 28,408 & 651.249 & 857 & 29,275 & 734.449 & 907 & 30,116 & 822.649 & 957 & 0,935 & $915.84 \mathrm{C}$ \\
\hline 808 & 28,425 & 652.864 & 858 & 29,292 & 736.164 & 908 & 30,133 & 824.464 & 958 & 30,952 & 917.764 \\
\hline 809 & 28,443 & 654.481 & 859 & 29,309 & 737.881 & 909 & 30,150 & 826.281 & 959 & 30,968 & 919.681 \\
\hline 810 & 28,460 & 656.100 & 860 & 29,326 & 739.600 & 910 & 30,166 & 828.100 & 960 & 30,984 & 921.600 \\
\hline 811 & 28,478 & 657.721 & 861 & 29,343 & 741.321 & 911 & 30,183 & 829.921 & 961 & 31,000 & 923.521 \\
\hline 812 & 28,496 & 659.344 & 862 & 29,360 & 743.044 & 912 & 30,199 & 831.744 & 962 & 31,016 & 925.444 \\
\hline 813 & 28,513 & 660.969 & 863 & 29,377 & 744.769 & 913 & 30,216 & 833.569 & 963 & 31,032 & 927.369 \\
\hline 814 & 8,531 & 662.596 & 864 & 29,394 & 746.496 & 914 & 30,232 & 835.396 & 964 & 31,048 & 929.296 \\
\hline 815 & 28,548 & 664.225 & 865 & 29,411 & 748.225 & 915 & 30,249 & 837.225 & 965 & 31,064 & 931.225 \\
\hline 816 & 28,566 & 665.856 & 866 & 29,428 & 749.956 & 916 & 30,265 & 839.056 & 966 & 31,081 & 933.156 \\
\hline 817 & 28,583 & 667.489 & 867 & 29,445 & 751.689 & 917 & 30,282 & 840.889 & 967 & 31,097 & 935.089 \\
\hline 818 & 28,601 & 669.124 & 868 & 29,462 & 753.424 & 918 & 30,299 & 842.724 & 968 & 31,113 & 937.024 \\
\hline 819 & 28,618 & 670.761 & 869 & 29,479 & 755.161 & 919 & 30,315 & 844.561 & 969 & 31,129 & 938.961 \\
\hline 820 & 8,636 & 672.400 & 870 & 29,496 & 756.900 & 920 & 30,332 & 846.400 & 970 & 31,145 & 940.900 \\
\hline 821 & 8,653 & 674.041 & 871 & 29,513 & 758.641 & 921 & 30,348 & 848.241 & 971 & 31,161 & $\overline{942.841}$ \\
\hline 822 & 28,671 & 675.684 & 872 & 29,530 & 760.384 & 922 & 30,364 & 850.084 & 972 & 31,177 & 944.784 \\
\hline 823 & 28,688 & 677.329 & 873 & 29,547 & 762.129 & 923 & 30,381 & 851.929 & 973 & 31,193 & 946.729 \\
\hline 824 & 28,705 & 678.976 & 874 & 29,563 & 763.876 & 924 & 30,397 & 853.776 & 974 & 31,209 & 948.676 \\
\hline 825 & 28,723 & 680.625 & 875 & 29,580 & 765.625 & 925 & 30,414 & 855.625 & 975 & 31,225 & 950.625 \\
\hline 826 & 28,740 & 682.276 & 876 & 29,597 & 767.376 & 926 & 30,430 & 857.476 & 976 & 31,241 & 952.576 \\
\hline 827 & 28,758 & 683.929 & 877 & 29,614 & 769.129 & 927 & 30,447 & 859.329 & 977 & 31,257 & 954.529 \\
\hline 828 & 28,775 & 685.584 & 878 & 29,631 & 770.884 & 928 & 30,463 & 861.184 & 978 & 31,273 & 956.484 \\
\hline 829 & 28,792 & 687.241 & 879 & 29,648 & 772.641 & 929 & 30,480 & 863.041 & 979 & 31,289 & 958.441 \\
\hline 830 & 28,810 & 688.900 & 880 & 29,665 & 774.400 & 930 & 30,496 & 864.900 & 980 & 31,305 & 960.400 \\
\hline 831 & 3,827 & 690.561 & 881 & 29,682 & 776.161 & 931 & 30,512 & 866.761 & 981 & 31,321 & 962.361 \\
\hline 832 & 28,844 & 692.224 & 882 & 29,698 & 777.924 & 932 & 30,529 & 868.624 & 982 & 31,337 & 964.324 \\
\hline 833 & 28,862 & 693.889 & 883 & 29,715 & 779.689 & 933 & 30,545 & 870.489 & 983 & 31,353 & 966.289 \\
\hline 834 & 28,879 & 695.556 & 884 & 29,732 & 781.456 & 934 & 30,561 & 872.356 & 984 & 31,369 & 968.256 \\
\hline 835 & 28,896 & 697.225 & 885 & 29,749 & 783.225 & 935 & 30,578 & 874.225 & 985 & 885 & 970.225 \\
\hline 836 & 28,914 & 698.896 & 886 & 29,766 & 784.996 & 936 & 30,594 & 876.096 & 986 & 31,401 & 972.196 \\
\hline 837 & 28,931 & 700.569 & 887 & 29,783 & 786.769 & 937 & 30,610 & 877.969 & 987 & 31,417 & 974.169 \\
\hline 838 & 28,948 & 702.244 & 888 & 29,799 & 788.544 & 938 & 30,627 & 879.844 & 988 & 31,432 & 976.144 \\
\hline 839 & 28,965 & 703.921 & 889 & 29,816 & 790.321 & 939 & 30,643 & 881.721 & 989 & 31,448 & 978.121 \\
\hline 840 & 28,983 & 705.600 & 890 & 29,833 & 792.100 & 940 & 30,659 & 883.600 & 990 & 31,464 & 980.100 \\
\hline 841 & 29,000 & 707.281 & 891 & 29,850 & 793.881 & 941 & 30,6 & 885.481 & 991 & 31,480 & 982.081 \\
\hline 842 & 29,017 & 708.964 & 892 & 29,866 & 795.664 & 942 & 30,692 & 887.364 & 992 & 1,496 & 984.064 \\
\hline 843 & 29,034 & 710.649 & 893 & 29,883 & 797.449 & 943 & 30,708 & 889.249 & 993 & 1,512 & 986.049 \\
\hline 844 & 29,052 & 712.336 & 894 & 29,900 & 799.236 & 944 & 30,725 & 891.136 & 994 & 31,528 & 988.036 \\
\hline 845 & 29,069 & 714.025 & 895 & 29,917 & 801.025 & 945 & 30,741 & 893.025 & 995 & 31,544 & 990.025 \\
\hline 846 & 9,086 & 715.716 & 896 & 29,933 & 802.816 & 946 & 30,757 & 894.916 & 996 & 31,559 & 992.016 \\
\hline 847 & 29,103 & 717.409 & 897 & 29,950 & 804.609 & 947 & 30,773 & 896.809 & 997 & 31,575 & 994.009 \\
\hline 848 & 29,120 & 719.104 & 898 & 29,967 & 806.404 & 948 & 30,790 & 898.704 & 998 & 1,591 & 996.004 \\
\hline 849 & 29,138 & 720.801 & 899 & 29,983 & 808.201 & 949 & 30,806 & 900.601 & 999 & 31,607 & 998.001 \\
\hline 850 & 29,155 & 722.500 & 900 & 30,000 & 810.000 & 950 & 30,822 & 902.500 & 1.000 & 31,623 & 1.000 .000 \\
\hline
\end{tabular}

